\title{
5. SITE 391: BLAKE-BAHAMA BASIN
}

\author{
Shipboard Scientific Party ${ }^{1}$
}

\section{SITE DATA}

Dates Occupied: 2-22 September 1975

Position: (Hole 391 ) $28^{\circ} 13.73^{\prime} \mathrm{N}$; $75^{\circ} 36.76^{\prime} \mathrm{W}$

(Holes 391A, B, C) $28^{\circ} 13.61 \mathrm{~N} ; 75$

Water Depth: 4974 meters (corrected PDR), 4995 meters (drill pipe)

Penetration: 1412 meters

Number of Holes: 4

Number of Cores: 77

Total Length of Cored Section: 714.5 meters

Total Core Recovered: 357.8 meters

Percentage Core Recovered: 50.1 per cent

Oldest Sediment Cored: Lower Tithonian red calcareous claystone at 1412 meters sub-bottom

Basement: Not reached

Principal Results: We drilled four holes at Site 391. Hole 391 was drilled at $28^{\circ} 13.73^{\prime} \mathrm{N}, 75^{\circ} 36.76^{\prime} \mathrm{W}$, and Holes 391A, 391B, and $391 \mathrm{C}$ were drilled at $28^{\circ} 13.61^{\prime} \mathrm{N}, 75^{\circ} 37.00^{\prime} \mathrm{W}$. The change in position was necessary to avoid a double target during re-entry attempts following loss of a re-entry cone.

A technical difficulty forced us to pull the pipe from Hole $391 \mathrm{~A}$ at 659 meters sub-bottom and repeated failures to re-enter the cone led us to drill Hole $391 \mathrm{C}$ with a single bit which penetrated to a record-breaking depth of 1412 meters before it failed. The hole terminated in Upper Jurassic red marl at least 250 meters above basement.

The Cenozoic section consists entirely of Quaternary hemipelagic clay and reworked Miocene carbonates. The Pliocene, entire lower Tertiary, and probably uppermost Cretaceous sediments are missing. The Miocene sediments comprise 500 meters of carbonate turbidites and intraclastic chalk breccias. These reworked carbonates were probably derived from the Bahama Bank and the Blake Plateau and transported to the basin by debris flows and turbidity currents.

Middle Cretaceous black clay directly underlies the Miocene chalk breccias. Below this we continuously cored a complete section of Neocomian limestone which is perhaps the best documented Lower Cretaceous biostratigraphic section yet recovered in the deep sea.

${ }^{1}$ William E. Benson, National Science Foundation, Washington, D.C.; Robert E. Sheridan, University of Delaware, Newark; Paul Enos, State University of New York, Binghamton; Tom Freeman, University of Missouri, Columbia; Felix M. Gradstein, Bedford Institute, Dartmouth, Nova Scotia; Ivar O. Murdmaa, P. P. Shirshov Institute of Oceanology, Academy of Sciences, Moscow; Léo Pastouret, Centre National pour l'Exploitation des Océans, Brest, France; Ronald R. Schmidt, Geologisch Instituut der Rijksuniversiteit Utrecht, the Netherlands; Daniel H. Stuermer, University of California, Los Angeles; Fred M. Weaver, Florida State University, Tallahassee; Paula Worstell, Scripps Institution of Oceanography, La Jolla, California.
The Cretaceous/Jurassic boundary is transitional and well documented at Site 391 and we recovered an unusually thick section of Upper Jurassic (Tithonian and Kimmeridgian) sediments.

We identified four of six prominent sub-bottom reflectors and correlated them with lithology. We did not penetrate the bottom two reflectors. Horizon $A$ is a Miocene-Cretaceous unconformity and horizon $\beta$ is the transition between clay and limestone at the base of the Aptian through the top of Neocomian. The top of Tithonian red clayey limestones marks another widespread reflector, horizon $\mathrm{C}$.

\section{BACKGROUND AND OBJECTIVES}

\section{Background}

The Blake-Bahama Basin is a distinctive abyssal area in the western North Atlantic Ocean (Figures 1 and 2), important geologically because it is underlain by the relatively weak magnetic anomalies of the enigmatic "quiet zone," and because it probably contains some of the oldest sediments beneath the Atlantic Ocean. Previous DSDP legs have drilled some of the shallower features around its margin, but penetration of its deeper parts has awaited the capability of, and time available for, multiple re-entry holes and the availability of seismic data which have revealed the depth to layers beneath horizon $A$ (Dillon et al., 1976).

Several prominent reflecting horizons underlie the Blake-Bahama Basin. Sheridan et al. (1974) have traced an important reflector across the basin to the base of the Blake Escarpment where it crops out, apparently exposed by bottom currents. Piston coring in the outcrop area has recovered upper Miocene turbidites presumably the interval responsible for the prominent reflector. The reflector underlies up to 1000 meters of hemipelagic mud which are piled onto the Bahama Outer Ridge and ponded west of the older Blake Outer Ridge (Figure 3). Sheridan et al. (1974) have inferred that these sediment piles were created by an abrupt decrease in the velocity of the Antarctic Bottom Water current after the late Miocene glacial maximum in the Antarctic. Thus we wanted to verify that this reflector is indeed a turbidite and to establish its age and lithology away from the outcrop area.

Below this upper "turbidite" reflector, associated with reflector $\mathrm{M}$ of Dillon et al. (1976), lies the ubiquitous horizon $A$, and, below that, $\beta$. Until recently, the small-volume airguns and single-channel profiling systems, generally available to oceanographic institutions, rarely penetrated below $A$, never $\beta$. Within the last year, however, 24-channel common-depth-point seismic reflection profiles have become available through a joint Institute Francais du Petrole/U.S. Geological Survey study made aboard R/V Florence (Dillon et al., 1976). Several of their profiles cross 


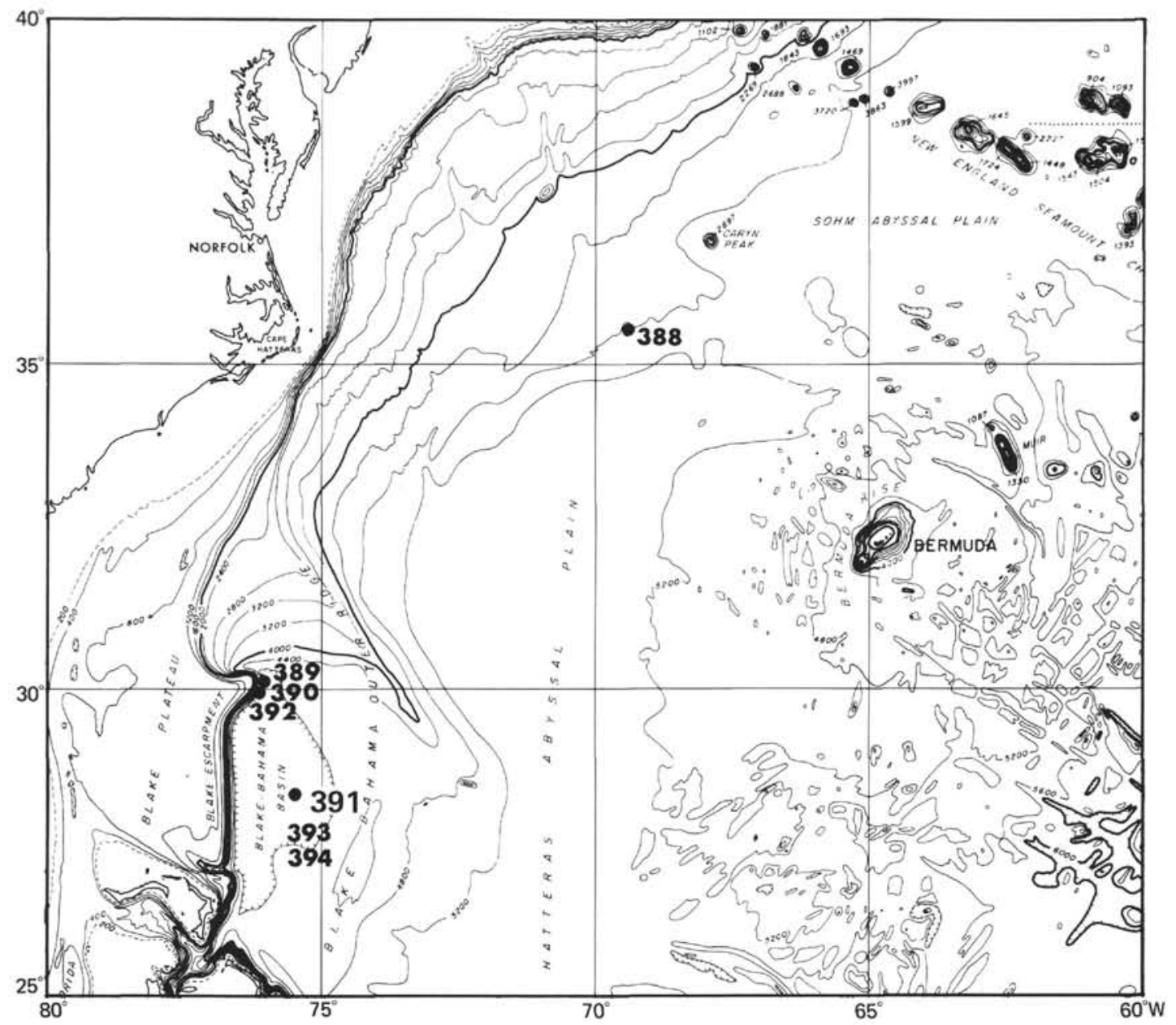

Figure 1. Map showing location of Site 391 relative to the Atlantic margin.

over the Blake Escarpment into the deep Blake-Bahama Basin and show for the first time the depth and character of basement in the basin (Figure 4) (Dillon, et al., 1976). Also, the previously suspected Upper Jurassic limestone can be traced across the basin on these profiles.

On the basis of a projection of the lithologies cored at nearby Site 101 (Hollister et al., 1972), the presence of the Cretaceous black clay and Neocomian-Tithonian limestone was also predicted at Site 391; but the westward extension of these units into the Blake-Bahama Basin also required testing.

Sonobuoy surveys made by Lamont-Doherty Geological Observatory near the IFP/USGS seismic reflection profile (available to Leg 44 scientists, courtesy of John Ewing) gave relatively low interval velocities, 1.69 to $2.81 \mathrm{~km} / \mathrm{sec}$, for the sediments above the oceanic basement which had a velocity of $4.98 \mathrm{~km} / \mathrm{sec}$. The low velocities in the sediments agree with the velocity analysis provided by IFP. The resulting calculated depths to basement at Site 391 indicate that the top of the basalt should lay at about 1660 meters sub-bottom or at a total depth of 6506 meters. This depth is just within reach of Glomar Challenger's operational drill string (Figure 4).

Site 391 is in a well-documented part of the "magnetic quiet zone"' (Figure 5), well away from the nearest fracture zones (Sheridan and Osburn, 1975). Nearby magnetic profiles made from $\mathrm{R} / \mathrm{V}$ Eastward show the well-documented Keathley magnetic anomaly sequence. The profiles also show reasonably good correlations of some of the smaller amplitude anomalies with the quiet zone (Osburn, 1975). Anomalies such as the comparatively well-developed Blake Spur (BS) anomaly (Taylor et al., 1968 ) and the $a$ anomaly (Drake et al., 1963) are easily identified, and several less prominent anomalies such as $Q 3$ and Q4 (Figure 6) can also be seen. Barrett and Keen (1976) have demonstrated that off Nova Scotia blocks with truly reversed polarity must be present within the otherwise normally polarized quiet zone. Keen and Barrett (1976) believe that the magnetic reversals they noted, specified as $M 26, M 27$, and $M 28$, correspond to reversed zones in the long, otherwise normal, Graham Interval with ages of approximately 156, 159, and $163 \mathrm{~m} . \mathrm{y}$. (Figure 7). These ages were obtained by assuming the ages given recently by Larson and Hilde (1975) for M22 and M25 and extrapolating the resulting spreading rates of $1.74 \mathrm{~cm} / \mathrm{yr}$ to anomalies $M 26, M 27$, and $M 28$.

Magnetic modeling of the $B S, a, Q 3$, and $Q 4$ anomalies of the Blake-Bahama Basin (Osburn, 1975) also suggests the presence of reversely magnetized blocks (Figure 6). Note, however, that the magnetization for the quiet zone 


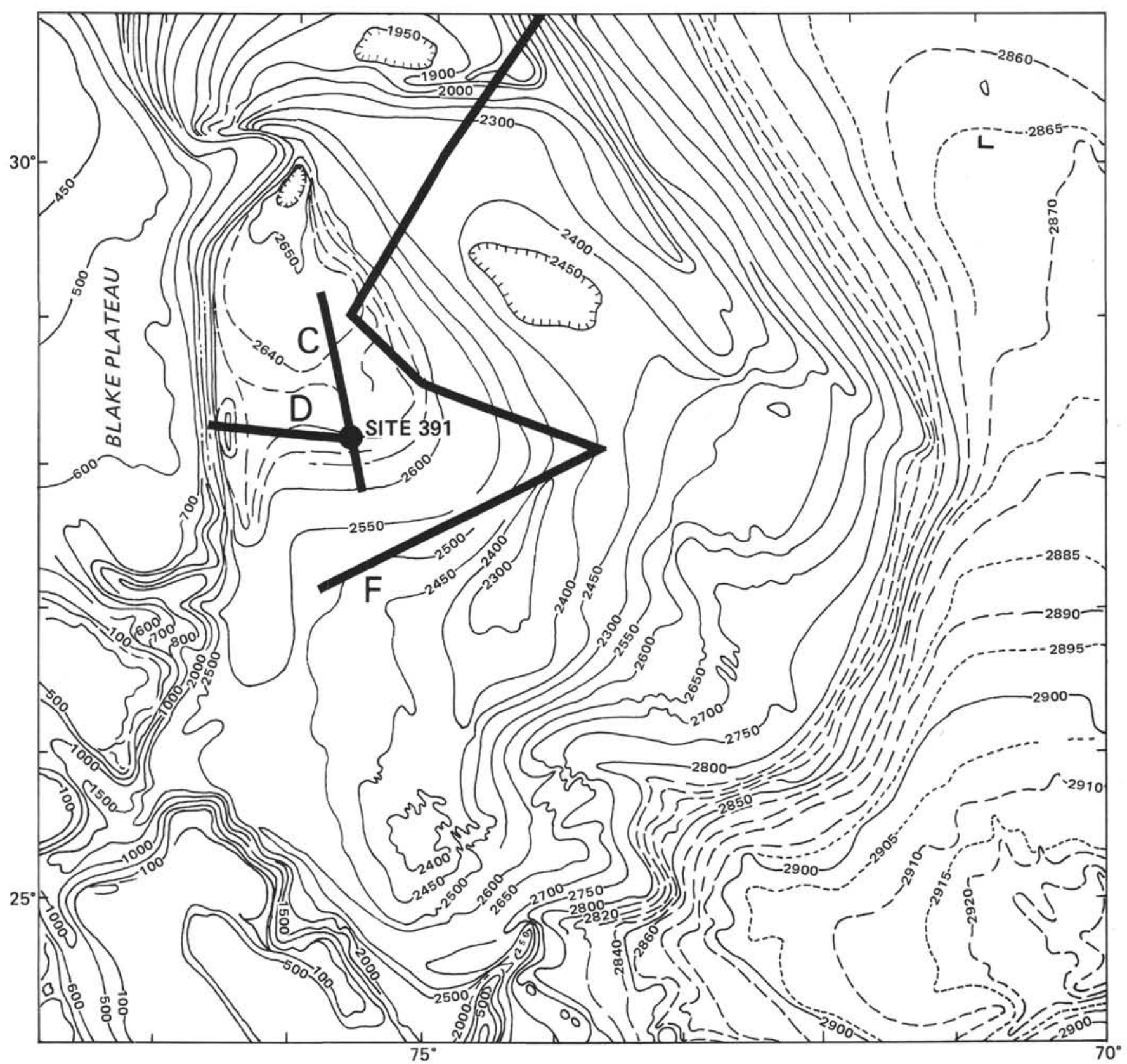

Figure 2. Detailed bathymetry of the Blake-Bahama Basin near Site 391. Depths in fathoms are on basis of computations by E. Schneider (personal communication). F is track of Vema 21 and $C$ is track of IFP-USGS (Dillon et al., 1976). D is track of Profile $\mathrm{MCl}$ of $\mathrm{R} / \mathrm{V}$ Conrad.

blocks must be $0.001 \mathrm{emu}$ as compared to 0.005 for the basement under the larger amplitude Keathley sequence. Quiet zone intervals $a, Q 3$ and $Q 4$ are correlated with the $M 27$ and $M 28$ reversals of Barrett and Keen (1976).

Using the approximate age of anomalies $M 23$ and $M 25$ (Larson and Hilde, 1975; Barrett and Keen, 1976), we calculate a spreading rate of $2.4 \mathrm{~cm} / \mathrm{yr}$ for the end of the Keathley sequence in the Blake-Bahama Basin (Figure 7). Extrapolation of this spreading rate gives a calculated age of Callovian (157-161 m.y.) for the M27 reversals and an age of Bathonian (163-164 m.y.) for the M28 reversal.

Note, however, that the new time scale of van Hinte $(1976 a, b)$ revises the ages of the paleomagnetic stratigraphy of the Middle Jurassic (Figure 7). On the basis of these new ages of $M 23$ and $M 25$, the calculated spreading rates in the Blake-Bahama Basin would be as high as $4 \mathrm{~cm} / \mathrm{yr}$ and the extrapolated age of the reversal $M 28$ at Site 391 would be approximately $153 \mathrm{~m} . \mathrm{y}$., or only Callovian. We hoped to resolve the difference in projected ages of basement and the resulting difference in spreading rates by drilling at Site 391.

\section{Objectives}

Drilling at Site 391 was the first attempt to sample the deep part of the Blake-Bahama Basin. Our major objectives in drilling this site were to: (1) establish the nature of several 


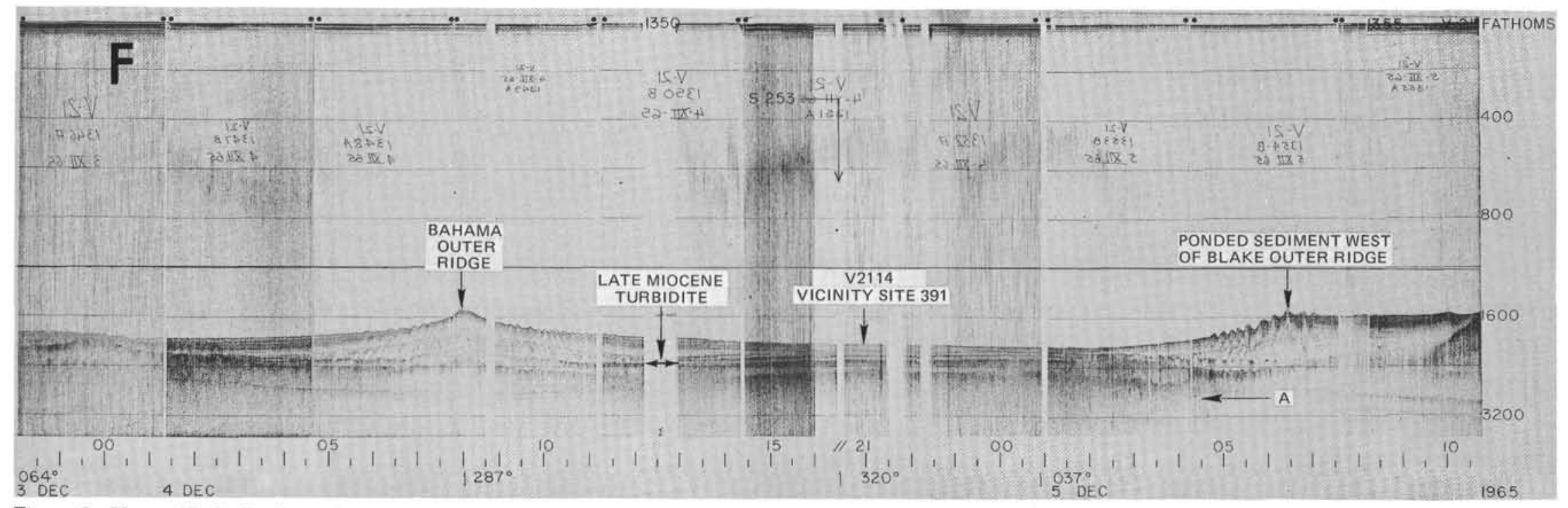

Figure 3. Vema 21 single-channel reflection profile near Site 391 along track $F$ shown in Figure 2. Note how the lower Miocene turbidite horizon underlies the younger ridges of hemipelagic muds. (Data are provided by Lamont-Doherty Geological Observatory.) 


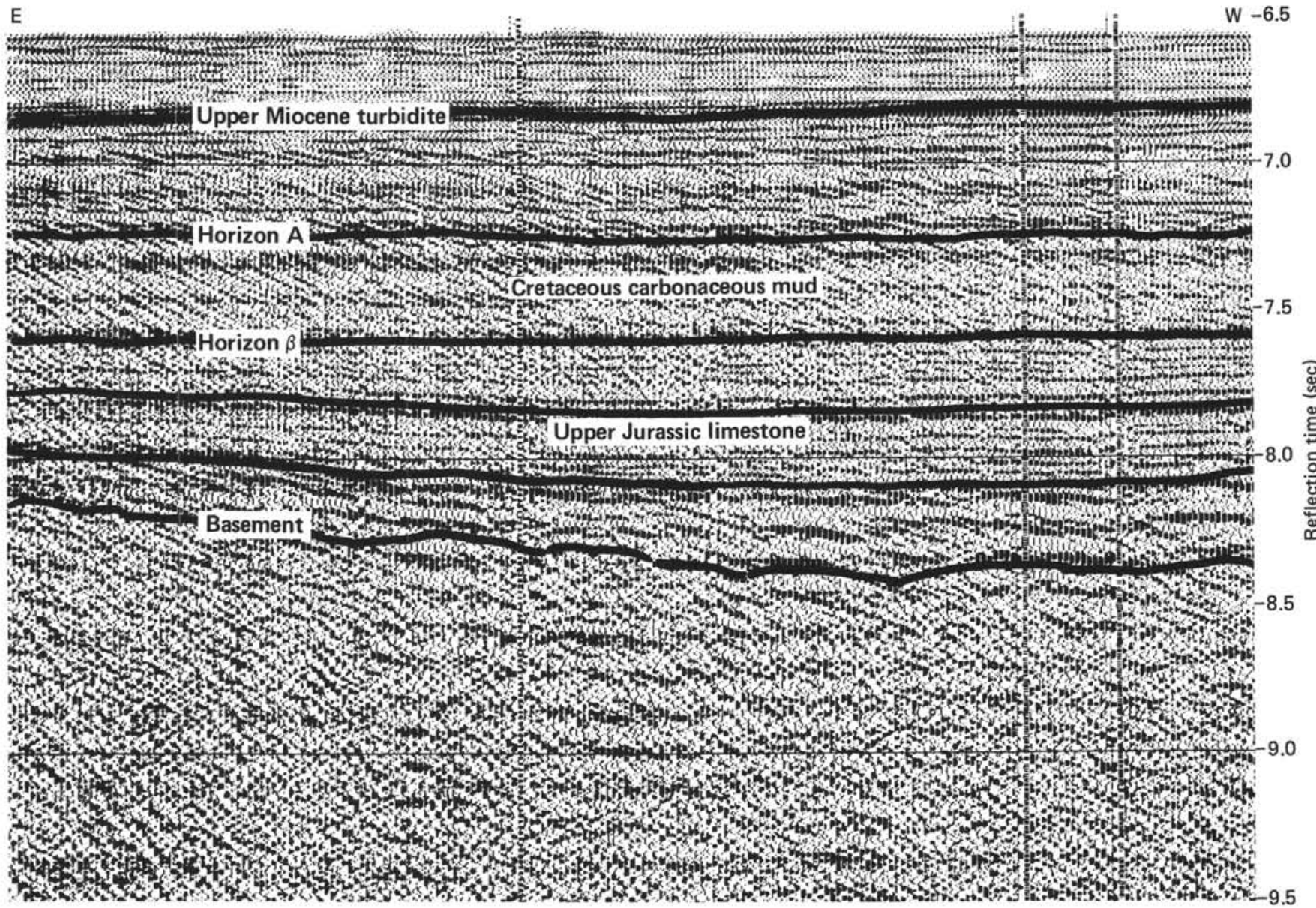

Figure 4. 24-fold multichannel seismic reflection profile MC 1 made by $R / V$ Conrad across the Blake-Bahama Basin west of Site 391. Horizons identified on basis of interpretation by Dillon et al., 1976 (data courtesy of Lamont-Doherty Geological Observatory).

prominent reflecting horizons; (2) determine the character of late Cenozoic sedimentation, especially turbidite deposition and its cessation, and the significant ridge building which supposedly occurred after the late Miocene (Ewing an Hollister, 1972); (3) verify the presence of and sample Cretaceous and Upper Jurassic sediments, especially the carbonaceous units, for organic geochemical and source bed analyses, and the basal limestones for analysis of Metalliferous sediments; (4) recover Middle and possibly Lower Jurassic starta (older than any thus far found in any ocean); and (5) determine the age and character of basement near the western margin of the "magnetic quiet zone," to establish the age of some possible mid-Early Jurassic reversals and spreading rates.

\section{OPERATIONS}

Site 391 was located on the flank of a slight 3-km-wide rise in basement at shot point 620 on profile FC II of the IFP/USGS survey (Figure 4). Here the basement is a little shallower and thus more accessible. Also, because of its distinct relief, it is easy to identify on the documenting seismic profile. The IFP/USGS survey was navigated precisely with Loran $\mathrm{C}$ and we presumed that the site could be easily reoccupied without seismic identification of the basement by Glomar Challenger.
Glomar Challenger approached the coordinates of Site 391 from the northwest at 0445 hours, 2 September $1975 .^{2}$ No survey was required as the site had been located on a 24-channel common-depth-point reflection profile of the IFP/USGS Blake-Bahama survey. A $16-\mathrm{kHz}$ beacon was dropped at 0800 hours after two satellite fixes indicated the ship was within a mile of the desired location at $28^{\circ} 13.9^{\prime} \mathrm{N}$, $75^{\circ} 36.8^{\prime} \mathrm{W}$. Subsequent fixes, however, indicated that we were about three miles to the east of this position - the result of a strong west-northwest current which steamed the ship between the time we received the satellite position data and had launched the beacon. We consequently steamed three miles west and dropped a $13.5-\mathrm{kHz}$ beacon at 1316 hours. The PDR showed a water depth of 4957 meters corrected (2620 fm uncorrected, 2712 fm corrected), but a mud-line core was taken (Hole 391) at a "felt" depth of 4986 meters - a 29-meter discrepancy.

Following recovery of the mud-line core, we "washed in" to a firm layer at 79.5 meters sub-bottom (the depth to which casing was to be set). We pulled the pipe and prepared to launch the re-entry cone at 1600 hours, 3 September. But at about 1700 hours when the bit had been

\footnotetext{
${ }^{2}$ Time given in the text is local time.
} 


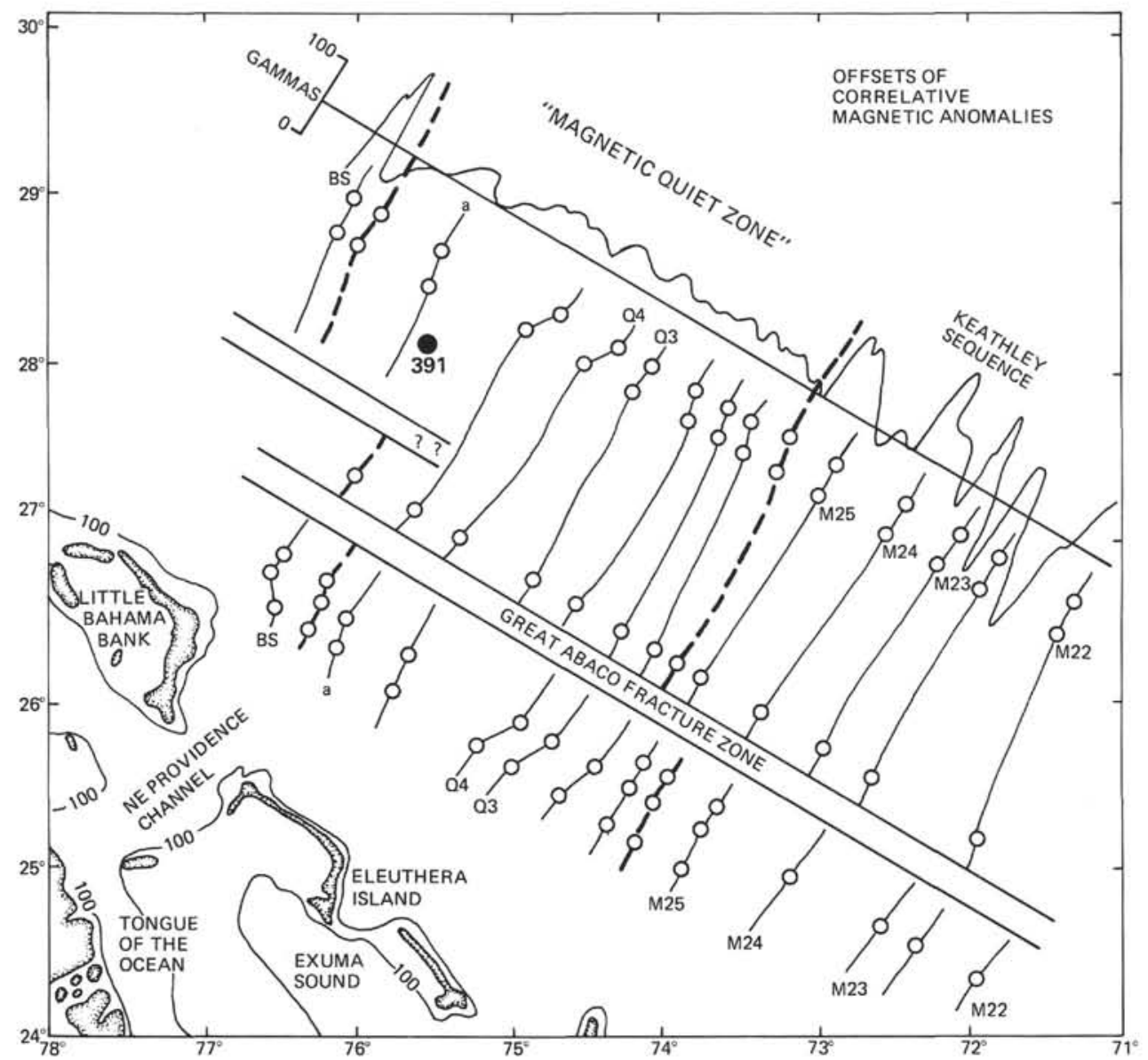

Figure 5. Location of Site 391 relative to correlative linear magnetic anomalies of magnetic quiet zone (after Sheridan and Osburn, 1975).

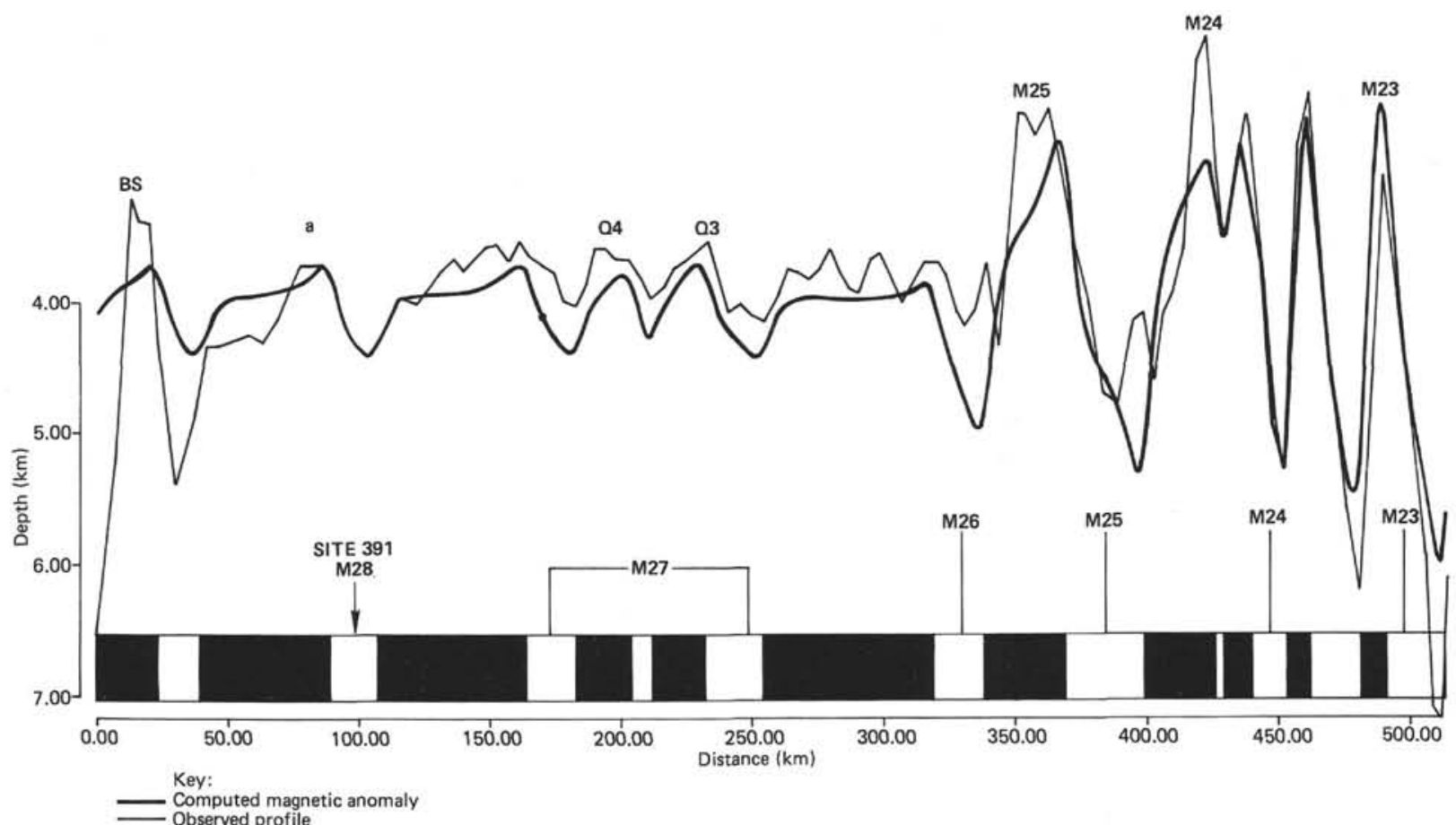

Figure 6. Computed magnetic anomaly compared with observed profile nearest Site 391 (Osburn, 1975). Reversed blocks west of Keathley have magnetization of 0.001 emu compared to 0.005 emu for Keathley blocks. Anomalies M23, M24, M25, Q3, Q4, a, BS are as identified by Sheridan and Osburn (1975) and reversal blocks M23-M28 are as correlated by Barrett and Keen (1976). 


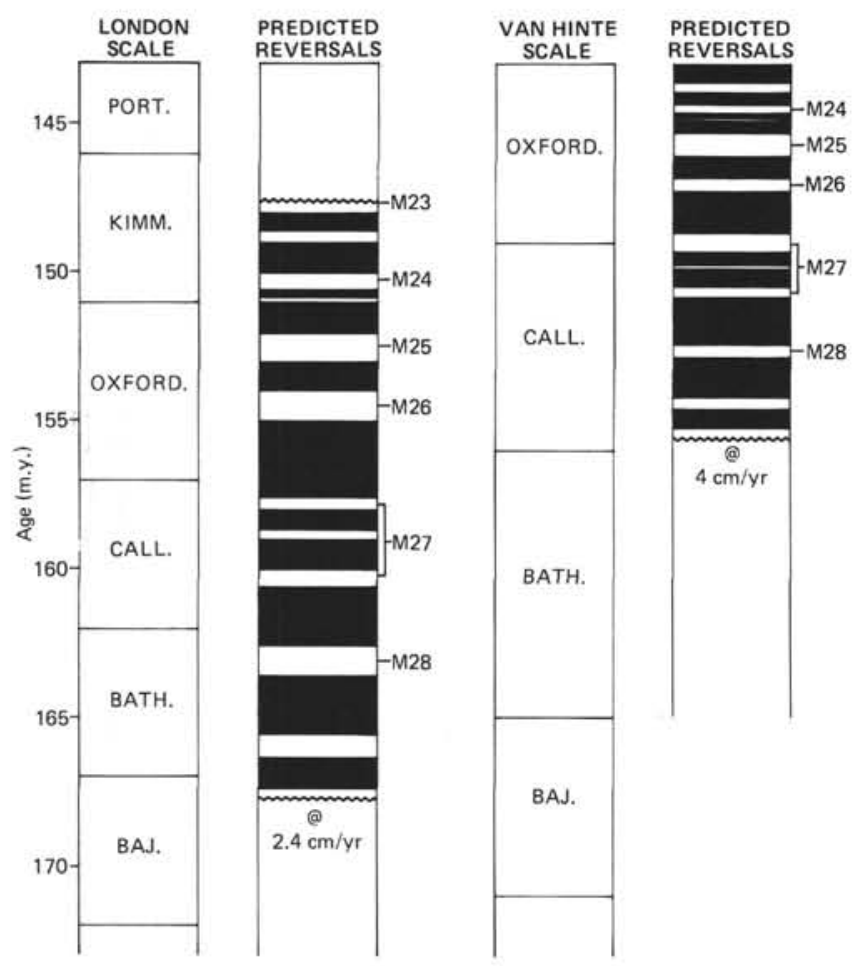

Figure 7. Projected ages of Jurassic magnetic reversals M23M28 as correlated for the Blake-Bahama Basin with these same reversals proposed by Barrett and Keen (1976). The London time scale used by Barrett and Keen (1976) gives a Bathonian age for M28; the new van Hinte $(1976 a, b)$ time scale gives a Callovian age.

lowered to only 120 meters, the re-entry cone disengaged and was lost. The three-spring dog-latches had apparently given way and/or slipped open. A strong 1.5 -knot current may have contributed to the loss of the cone.

To prevent the possibility of having two real targets during re-entry, Challenger was offset 1500 feet to the west and a second cone and casing was successfully launched at about 0730 hours, 4 September. At 2100 hours, 4 September 1975, the bit felt bottom at 4978 meters, in good agreement with the PDR depth of 4974 meters. We expected to wash the 71 meters of casing into firm bottom at 5049 meters, but the bit stopped at firm layer at only 5026 meters. This could have meant that the base of the cone was still 19 meters above the bottom! After repeated futile attempts to wash or chip away the sub-bottom layer to more deeply seat the cone, the drillers concluded that it was on bottom and that the depth calculations were incorrect. During later operations the pipe was remeasured and a new average of 28.15 meters/stand replaced the previous value of 28.05 meters/stand. By recomputation on the basis of the new figure, the "felt depth," previously 4978 meters, became 4995 meters which corresponds to a somewhat firm layer below a very soft bottom at 4974 meters. The firm layer that stopped the cone became 5051 meters (rather than $5026 \mathrm{~m}$ ), only 2 meters more than the anticipated depth. However, and also because the uppermost \pm 20 meters of sediment is apparently extremely soft, we were never certain while drilling the site what caused the discrepancy between the PDR and drill-pipe depth measurements.
We lowered the shifting tool to disengage the bit from the re-entry casing and began drilling Hole $391 \mathrm{~A}$ at 0010 hours, 5 September. Our problems began immediately when the shifting tool failed to detach the pipe from the casing. The shifting tool itself became lodged in the pipe when a safety pin sheared during a retrieval attempt. During a second attempt to retrieve the shifting tool, the sand line parted and the broken piece fell into the pipe. (At about this time, and for no known reason, the latches to the casing released so that the bit could be rotated.) Following a tedious "fishing", operation, the rig crew retrieved the kinked sand line, a fishing tool also lost down the pipe, and the shifting tool. But despite these successes, the dogs from the shifting tool had apparently became wedged between the inner and outer core barrels and the inner core barrel could not be moved. Thus the entire drill string had to be pulled and the operation resulted in the recovery of only Section 391A-1-1. The drill string was on deck at 0930 hours, 6 September. Stiff clay coated the latching sub which should have been comfortably inside the casing - a further indication that something was malfunctioning at the re-entry cone.

Prior to the re-entry attempt, the stands were remeasured resulting in the new conversion factor, mentioned above.

The first re-entry attempt was made at 2230 hours, 6 September. We thought we had successfully re-entered the hole, but when the drill pipe stopped abruptly at 5012 meters instead of dropping to the expected 5069.5 meters we attempted to re-enter a second time. Again, following what appeared to be a successful re-entry, the pipe ran in only to 5000 meters. After some loss of time owing to malfunction of the EDO probe, a third "successful" attempt was made. At 2038 hours, 7 September the cone was stabbed, but the bit again hit firm material at 5002 meters ( $28 \mathrm{~m}$ sub-bottom).

We recovered a core of well-bedded mud from the third re-entry attempt which proved that sediments had not "flowed" into the casing. We thus assumed that all three re-entries had been successful, but that the cone and the upper part of the casing had been sheared off and moved laterally while we were attempting to disengage it from the bit and fish debris out of the pipe. (This could also account for the stiff mud found on the latching sub noted above.) We were never able to prove this conclusively as a later re-entry attempt was not successful (see below). Indeed, we may never have re-entered the cone during Leg 44.

Drilling at Hole 391A resumed at 2310 hours, 7 September. We recovered 21 cores and drilled to a depth of 658.5 meters. Because we assumed that we had re-entered the cone, we designated the uppermost core recovered 391A-2. Core 391A-1 was recovered during the earlier drilling at Hole 391A (see above) and because the cone moved laterally (or at least we thought so at the time) Core 2 was recovered from an interval higher than Core 1.

Drilling at Hole $391 \mathrm{~A}$ was halted at 2330 hours, 9 September, when, as we learned later, an Allen pivot pin backed out of the fishing neck of the barrel and firmly wedged the core barrel in the drill pipe. The problem was discovered when the overshot, sent to retrieve the core barrel, ran full speed into the inner barrel wedged about 2000 meters down the pipe.

Then began perhaps the most trying period of the cruise. Because the bit had been retracted above the mudline to 
remove the stuck core barrel, we had to re-enter the cone to continue drilling Hole 391A. But over a three-day period (10 September to 13 September), nine attempts to re-enter the cone were unsuccessful. Four of the tries were aborted because of various malfunctions of the EDO tool. In four cases we stabbed a target, but each time the bit stopped at 5000 meters and did not re-enter Hole 391A. The seventh attempt was terminated by a medical emergency which required radio transmission. Our Chief Steward, Clinton Rouse, was stricken with what ultimately was a fatal cerebral hemorrhage on the evening of 12 September.

We abandoned our attempt to re-enter Hole 391A after the ninth unsuccessful try. The reasons the re-entry attempts were not successful are unclear. Attempts to re-enter a cone during Leg 44A were also unsuccessful and in that case the cone was thought to have been obscured by extremely soft bottom sediments. During tries 6 and 7 on Leg 44, three clear targets, readily identified as cone reflectors, were seen. Targets during the later attempts, however, were generally poor. This could have resulted from (1) poor performance of the EDO tools, or (2) partial burial of the cone. Possibly Hole $391 \mathrm{~A}$ was itself drilled outside the cone, in which case an accurate re-entry into the cone would have been interpreted as unsuccessful - as the bit would have stopped at 5000 meters. Alternatively, the cone may have sheared from its casing, and tilted sideways, and thus accurate re-entries into the cone would also have been offset from the previous hole and encountered firm sediments.

Following our unsuccessful attempts to re-enter Hole $391 \mathrm{~A}$, we decided to attempt deep penetration with a single bit and Hole $391 \mathrm{C}$ was spudded in at 1300 hours, 13 September. (The designation "Hole 391B" had been pre-empted by a mudline core taken on 6 September.)

Coring at Hole $391 \mathrm{C}$ progressed without major interruption to 21 September. Although penetration rates decreased with increasing depth as we drilled into progressively harder formations and recovery of the red Jurassic clayey limestones was only fair, the gage of the core remained good and the hole stayed open. We had hoped to penetrate the oldest part of the sedimentary section but, while cutting Core 54 at 0400 hours on 22 September, the bit failed and the pipe could no longer be rotated. Accordingly, the pipe was pulled at 0700 hours after a record-breaking penetration of 1412 meters. The bit, shown in Figure 8, had lost three of its four cones and was found with a piece of hard gray limestone in its mouth.

We cored 54 cores in Hole 391C, and the hole ended in lower Tithonian claystone. Thus Site 391 was abandoned without achieving total penetration of the sedimentary column. At 1750 hours the tools were laid on the deck and Challenger left for Site 392.

Coring and drilling results for Site 391 are given on Table 1.

\section{LITHOLOGY}

\section{Introduction}

Four holes were drilled at Site 391. Only 2.3 meters were recovered from Hole 391, a mud-line test. Hole 391A penetrated to a sub-bottom depth of 95.5 meters, but uncertainty about the vertical position of the re-entry cone

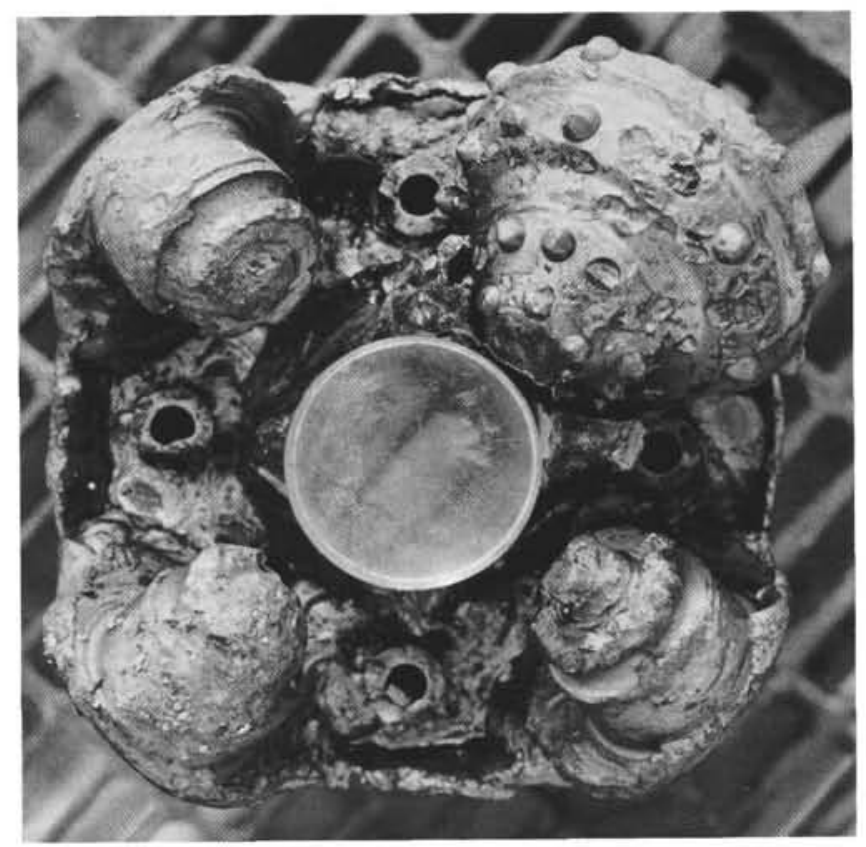

Figure 8. Bit which drilled to a record breaking depth $(1412 \mathrm{~m})$ in Hole $391 \mathrm{C}$.

prompted us to pull pipe above the cone and take a second mud-line core (Hole 391B). We recovered 9.3 meters from 0-9.5 meters sub-bottom in Core 391B-1. Upon re-entering Hole 391A, owing to an apparent separation of the casing, the bit encountered sediments above the level of Core 391A-1, so the depth of Core 391A-2 (5.0 m of sediments from a sub-bottom depth of $31.5-41.0 \mathrm{~m}$ ) is anomalously higher than that of Core 391A-1. Hole 391A was washed from 41.0-145.5 meters, followed by spot coring through Core 391A-21 to a sub-bottom depth of 658 meters. We had to withdraw from Hole $391 \mathrm{~A}$ because of technical difficulties, and after several futile re-entry attempts, Hole $391 \mathrm{C}$ was spudded in and drilled to a depth of 1412 meters sub-bottom depth.

The geologic section at Site 391 , as illuminated by 77 "spot"' cores, was divided into five lithologic units (Table 2 and Figure 9). On the basis of megascopic and microscopic examination of 357.7 meters $(25 \%)$ of the total 1412 meters of sediments penetrated, Figures 10,11 , and 12 summarize the major components comprising the sediments of the five units. (Figure 11 is in back pocket.)

\section{Unit 1}

Unit 1 was sampled in all four holes: 391, 391A, 391B, and $391 \mathrm{C}$ (Table 2). Its base is within Core $391 \mathrm{~A}-3$ at 145 $\mathrm{cm}$ below the top of Section 1, so its thickness $(146.9 \mathrm{~m})$ is well established. The principal lithology of unit 1 is gray (5Y 5/1) to brown (7.5YR 5/2) silty clay. Average abundances of constituent particles are shown in Table 3 . The average $\mathrm{CaCO}_{3}$ content of unit 2 (determined following the cruise by LECO analyses, see Appendix I), is 18 per cent.

The terrigenous character of unit 1 is manifest in its high clay content and in the presence of detrital quartz and mica. A decrease in quartz and mica with an increase in carbonate defines the base of unit 1 at Core $3-1,142 \mathrm{~cm}$. 
TABLE 1

Coring Summary, Site 391

\begin{tabular}{|c|c|c|c|c|c|c|c|}
\hline \multirow[b]{2}{*}{ Core } & \multicolumn{2}{|c|}{ Cored Interval } & & & & & \\
\hline & $\begin{array}{l}\text { Total Depth } \\
\quad(\mathrm{m})\end{array}$ & $\begin{array}{l}\text { Sub-bottom Depth } \\
(\mathrm{m})\end{array}$ & $\begin{array}{l}\text { Cored } \\
(\mathrm{m})\end{array}$ & $\begin{array}{l}\text { Recov } \\
(\mathrm{m})\end{array}$ & $(\%)$ & Lithology & Time-Rock Unit \\
\hline Hole 391 & & & & & & & \\
\hline 1 & $4981.0-4985.5$ & $0.0-4.5$ & 4.5 & 2.3 & 51 & Calcareous clay and marly nannofossil ooze & Upper Pleistocene: Holocene \\
\hline Total & 4985.5 & 4.5 & 4.5 & 2.3 & 51 & & \\
\hline Hole 391 & & & & & & & \\
\hline 1 & $4974.0-4983.5$ & $0.0-9.5$ & 9.5 & 9.3 & 98 & Clay, silty clay and foram-nannofossil ooze & Upper Pleistocene: Holocene \\
\hline Total & 4983.5 & 9.5 & 9.5 & 9.3 & 98 & & \\
\hline Hole 391 & & & & & & & \\
\hline 1 & $5060-5069.5$ & $86.0-95.5$ & 9.5 & 8.1 & 85 & Silty clay, foram "sand" and marly nannofossil ooze & Lower Pleistocene \\
\hline 2 & $5005.5-5014.0$ & $31.5-41.0^{\mathrm{a}}$ & 9.5 & 5.0 & 53 & Silty clay and marly nannofossil ooze & Upper Pleistoene-Holocene ${ }^{\mathrm{a}}$ \\
\hline 3 & $5119.5-5129.0$ & $145.5-155.0$ & 9.5 & 8.2 & 86 & Calcareous clay and calcareous ooze & Lower Pleistocene; upper Miocene \\
\hline 4 & $5176.5-5186.0$ & $202.5-212.0$ & 9.5 & 6.2 & 65 & Chalk and marly chalk with clay and claystone & Upper Miocene;middle Miocene \\
\hline 5 & $5233.5-5243.0$ & $259.5-269.0$ & 9.5 & 9.5 & 100 & Intraclastic marly chalk & Middle Miocene \\
\hline 6 & $5290.5-5300.0$ & $316.5 \cdot 326.0$ & 9.5 & 7.7 & 81 & Intraclastic chalk with mudstone and limestone & Middle Miocene \\
\hline 7 & $5300.0-5309.5$ & $326.0-335.5$ & 9.5 & 7.2 & 76 & Radiolarian mudstone & Middle Miocene \\
\hline 8 & $5309.5-5319.0$ & $335.5-345.0$ & 9.5 & 1.4 & 15 & Radiolarian mudstone and muddy radiolarite & $\begin{array}{l}\text { Middle Miocene (with displaced lower } \\
\text { Migcene interval) }\end{array}$ \\
\hline 9 & $5328.5-5338.0$ & $354.5-364.0$ & 9.5 & 9.5 & 100 & Intraclastic marly chalk & Upper lower and lower middle Miocene \\
\hline 10 & $5347.5-5357.0$ & $373.5-383.0$ & 9.5 & 9.5 & 100 & Intraclastic marly chalk & Upper lower and lower middle Miocene \\
\hline 11 & $5385.5-5395.0$ & $411.5-421.0$ & 9.5 & 8.7 & 92 & Intraclastic chalk & Upper lower and lower middle Miocene \\
\hline 12 & $5442.5-5452.0$ & $468.5-478.0$ & 9.5 & 9.5 & 100 & Intraclastic chalk and marly intraelastic chalk & Lower Miocene \\
\hline 13 & $5449.5-5509.0$ & $525.5-535.0$ & 9.5 & 9.5 & 100 & Siliceous mudstone, chalk, and marly chalk & Lower Miocene \\
\hline 14 & $5509.0-5518.5$ & $535.0-544.5$ & 9.5 & 0.01 & $<1$ & Chalk & Lower Miocene \\
\hline 15 & $5518.5-5528.0$ & $544.5-554.0$ & 9.5 & 0.05 & $<1$ & Chalk & Lower Miocene \\
\hline 16 & $5528.0-5537.5$ & $554.0-563.5$ & 9.5 & 2.2 & 23 & Limestone and siliccous mudstone & Lower Miocene \\
\hline 17 & $5537.5-5547.0$ & $563.5-573.0$ & 9.5 & 5.0 & 53 & Chalk and siliceous mudstone & Lower Miocene \\
\hline 18 & $5547.0-5556.5$ & $573.0-582.5$ & 9.5 & 0.1 & 1 & Mudstone & Lower Miocene \\
\hline 19 & $5556.5-5566.0$ & $582.5-592.0$ & 9.5 & 5.2 & 55 & Claystone, chalk and marly chalk & Lower Miocene \\
\hline 20 & $5613.5-5623.0$ & $639.5-649.0$ & 9.5 & 8.3 & 87 & Claystone and nannofossil chalk & Lower Miocene \\
\hline 21 & $5623.0-5632.5$ & $649.0-658.5$ & 9.5 & 9.1 & 96 & Silty claystone and claystone & (Indeterminate) \\
\hline Total & 5632.5 & 658.5 & 199.5 & 129.96 & 65 & & \\
\hline Hole $391 \mathrm{C}$ & & & & & & & \\
\hline 1 & $5309.5-5319.0$ & $335.5 \cdot 345.0$ & 9.5 & 3.1 & 33 & Nannofossil and foram ooze, and nannofossil chalk & (Displaced Pleistocene) \\
\hline 2 & $5585.0-5594.5$ & $611.0-620.5$ & 9.5 & 9.5 & 100 & Intraclastic chalk & Lower Miocene \\
\hline 3 & $5632.5-5642.0$ & $658.5-668.0$ & 9.5 & 0.2 & 2 & Chalk & (Indeterminate) \\
\hline 4 & $5642.0-5651.5$ & $668.0-677.5$ & 9.5 & 0.7 & 7 & Micaceous claystone and sandy silt & (Indeterminate) \\
\hline 5 & $5651.5-5561.0$ & $677.5-687.0$ & 9.5 & 1.0 & 11 & Claystone and silty claystone & Albian-Upper Cretaceous \\
\hline 6 & $5661.0-5670.5$ & $687.0-696.5$ & 9.5 & 9.5 & 100 & Claystone with silt laminae & Albian-Upper Cretaceous \\
\hline 7 & $5699.0-5708.5$ & $725.0-734.5$ & 9.5 & 2.0 & 21 & Claystone and claystone with silt stringers & (Indeterminate) \\
\hline 8 & $5756.0-5765.5$ & $782.0-791.5$ & 9.5 & 2.2 & 23 & Claystone, clayey siltstone, and siltstone & Cretaceous \\
\hline 9 & $5813.0-5822.5$ & $829.5-839.0$ & 9.5 & 4.2 & 44 & Claystone with sideritic marly limestone & Lower Albian-upper Aptian \\
\hline 10 & $5870.0-5879.5$ & $896.0-905.0$ & 9.5 & 3.9 & 41 & Silty claystone with limestone and sideritic chalk & Lower Albian-upper Aptian \\
\hline 11 & $5898.5-5908.0$ & $924.5-934.0$ & 9.5 & 4.7 & 49 & Calcareous claystone and silty calcareous claystone & (?) Upper Aptian \\
\hline 12 & $5927.0-5936.5$ & $953.0-962.5$ & 9.5 & 8.6 & 91 & Calcareous claystone and nannofossil limestone & Aptian \\
\hline 13 & $5955.5-5965.0$ & $981.5-991.0$ & 9.5 & 0.2 & 2 & 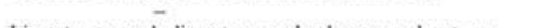 & Aptian \\
\hline 14 & $5974.5-5984.0$ & $1000.5-1010.0$ & 9.5 & 3.8 & 40 & Limestone, marly limestone and calcareous claystone & Batremian \\
\hline 15 & $5984.0-5993.5$ & $1010.0-1019.5$ & 9.5 & 4.2 & 44 & Marly limestone with calcareous and silty claystone & Lower Barremian-Upper Valanginian \\
\hline 16 & $5993.5-6003.0$ & $1019.5-1029.0$ & 9.5 & 5.6 & 59 & Limestone with calcareous claystone and sandy siltstone & Lower Barremian \\
\hline 17 & $6003.0-6012.5$ & $1029.0-1038.5$ & 9.5 & 2.4 & 25 & Sandy limestone and calcareous claystone & Lower Barremian-Upper Valanginian \\
\hline 18 & $6012.5-6022.0$ & $1038.5-1048.0$ & 9.5 & 1.1 & 12 & Sandy limestone and calareous claystone & Lower Barremian-Upper Valanginian \\
\hline 19 & $6022.0-6031.5$ & $1048.0-1057.5$ & 9.5 & 0.0 & 0 & - & - \\
\hline 20 & $6031.5 \cdot 6041.0$ & $1057.5-1067.0$ & 9.5 & 0.4 & 4 & Sandy limestone & Lower Barremian-Upper Valanginian \\
\hline 21 & $6060.0-6069.5$ & $1086.0-1095.5$ & 9.5 & 5.5 & 58 & Silty limestone, marly limestone and calcareous claystone & Lower Barremian-Upper Valanginian \\
\hline 22 & $6069.5-6078.0$ & $1095.5-1104.0$ & 9.5 & 0.05 & 0.6 & - & Lower Barremian-Upper Valanginian \\
\hline 23 & $6088.5-6098.6$ & $1114.5-1124.0$ & 9.5 & 0.0 & 0 & 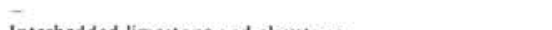 & - \\
\hline 24 & $6098.0-6107.5$ & $1124.0-1133.5$ & 9.5 & 8.5 & 89 & Interbedded limestone and claystone & Lower Valanginian-Upper Berriasian \\
\hline 25 & $6107.5-6117.0$ & $1133.5-1143.0$ & 9.5 & 5.7 & 60 & Interbedded limestone and claystone & Lower Valanginian-Upper Berriasian \\
\hline 26 & $6117.0-6126.5$ & $1143.0-1152.5$ & 9.5 & 5.0 & 53 & Interbedded limestone and claystone & Lower Valanginian-Upper Berriasian \\
\hline 27 & $6126.5-6136.0$ & $1152.5 \cdot 1162.0$ & 9.5 & 5.7 & 60 & Interbedded limestone and claystone & Lower Valanginian-Upper Berriasian \\
\hline 28 & $6136.0-6145.5$ & $1162.0-1171.5$ & 9.5 & 4.7 & 49 & Interbedded limestone and claystone & Lower Valanginian-Upper Berriasian \\
\hline 29 & $6145.5-6155.0$ & $1171.5-1181.0$ & 9.5 & 7.1 & 75 & Interbedded limestone and claystone & Lower Valanginian-Upper Berriasian \\
\hline 30 & $6155,0-6164.5$ & $1181.0-1190.5$ & 9.5 & 5.1 & 54 & Interbedded limestone and claystone & Lower Valanginian-Upper Berriasian \\
\hline 31 & $6164.5-6174.0$ & $1190.5-1200.0$ & 9.5 & 8.5 & 89 & Laminated limestone within claystone beds & Lower Valanginian-Upper Berriasian \\
\hline 32 & $6174.0-6183.5$ & $1200.0-1209.5$ & 9.5 & 5.1 & 54 & Interbedded laminated and bioturbated limestone & Lower Valanginian-Berriasian \\
\hline 33 & $6183.5-6193.0$ & $1209.5-1219.0$ & 9.5 & 3.8 & 40 & Interbedded laminated and bioturbated limestone & Lower Valanginian-Berriasian \\
\hline 34 & $6193.0-6202.5$ & $1219.0-1228.5$ & 9.5 & 5.1 & 54 & Clayey limestone & Lower Berriasian-Upper Tithonian \\
\hline 35 & $6202.5-6212.0$ & $1228.5-1238.0$ & 9.5 & 6.1 & 64 & Clayey limestone with laminated limestone beds & Lower Berriasian-Upper Tithonian \\
\hline 36 & $6212.0-6221.5$ & $1238.0-1247.5$ & 9.5 & 7.1 & 75 & Clayey limestone with laminated limestone beds & Lower Berriasian-Upper Tithonian \\
\hline 37 & $6221.5-6231.0$ & $1247.5-1257.0$ & 9.5 & 2.0 & 21 & Interbedded laminated and bioturbated limestone & Lower Berriasian-Upper Tithonian \\
\hline 38 & $6231.0-6240.5$ & $1257.0-1266.5$ & 9.5 & 6.0 & 63 & Limestone with clayey stringers and chert & Lower Berriasian-Upper Tithonian \\
\hline 39 & $6240.5-6250.0$ & $1266.5 \cdot 1276.0$ & 9.5 & 0.3 & 66 & Limestone with clayey stringers and thin claystone beds & Lower Berriasian-Upper Tithonian \\
\hline 40 & $6250.0-6259.5$ & $1276.0-1285.5$ & 9.5 & 6.3 & 66 & Limestone with clayey stringers and thin claystone beds & Lower Berriasian-Upper Tithonian \\
\hline 41 & $6259.5-6269.0$ & $1285.5 \cdot 1295.0$ & 9.5 & 6.1 & 64 & Limestone with clayey stringers and thin claystone beds & Lower Berriasian-Upper Tithonian \\
\hline 42 & $6269.0-6278.5$ & $1295.0-1304.5$ & 9.5 & 7.1 & 74 & Limestone with clayey stringers and thin claystone beds & Lower Berriasian-Upper Tithonian \\
\hline 43 & $6278.5-6288.0$ & $1304.5-1314.0$ & 9.5 & 6.0 & 63 & Limestone with clayey stringers and thin claystone beds & Lower Berriasian-Upper Tithonian \\
\hline 44 & $6288.0-6297.5$ & $1314.0-1323.5$ & 9.5 & 8.0 & 84 & Limestone with clayey stringers and thin claystone beds & Lower Berriasian-Upper Tithonian \\
\hline 45 & $6297.5-6307.0$ & $1323.5-1333.0$ & 9.5 & 4.2 & 44 & $\begin{array}{l}\text { Limestone with clayey stringers and green and red } \\
\text { limestone beds }\end{array}$ & Lower Tithonian \\
\hline 46 & $6307.6-6316.5$ & $1333.0-1342.5$ & 9.5 & 1.3 & 15 & Interbedded clayey limestone and calcalcareous claystone & Lower Tithonian \\
\hline 47 & $6316.5-6326.0$ & $1342.5 \cdot 1352.0$ & 9.5 & 1.0 & 11 & Limestone, clayey limestone, and calcareous claystone & Lower Tithonian \\
\hline 48 & $6326.0-6335.5$ & $1352.0-1361.5$ & 9.5 & 1.9 & 20 & Limestone with calcareous claystone and clay stringers & Lower Tithonian \\
\hline 49 & $6335.5 \cdot 6345.0$ & $1361.5-1371.0$ & 9.5 & 1.7 & 18 & Limestone and calcareous claystone & Lower Tithonian \\
\hline 50 & $6345.0-6354.5$ & $1371.0-1380.5$ & 9.5 & 1.3 & 14 & Calcareous claystone with calcareous silt and clay stringers & Lower Tithonian \\
\hline 51 & $6354.5-6359.5$ & $1380.5-1385.5$ & 5.0 & 1.7 & 34 & Calcareous claystone & Lower Tithonian \\
\hline 52 & $6364.0-6373.5$ & 1390.0-1399.5 & 9.5 & 5.0 & 53 & Calcareous claystone with silt stringers & Lower Tithonian \\
\hline 53 & $6373.5-6383.0$ & $1399.5 \cdot 1409.0$ & 9.5 & 4.1 & $\Delta$ & Claystone & Lower Tithonian \\
\hline 54 & $6383.0-6386.0$ & $1409.0 \cdot 1412.0$ & 3.0 & 4.1 & 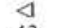 & Claystone & Lower Tithonian \\
\hline Total & 6386.0 & 1412.0 & 502.0 & 216.25 & 43 & & \\
\hline
\end{tabular}

${ }^{a}$ See Operations and Lithology sections for explanation of why sub-bottom depth less than Core 1. 
TABLE 2

Summary of Lithologic Units, Site 391

\begin{tabular}{|c|c|c|c|c|c|c|}
\hline Unit & Lithology & Time-Rock Unit & $\begin{array}{l}\text { Apparent } \\
\text { Thickness } \\
\text { (m) }\end{array}$ & $\begin{array}{l}\text { Sub-bottom } \\
\text { Depth of Top } \\
(\mathrm{m})\end{array}$ & $\begin{array}{l}\text { Recovery } \\
(\%)\end{array}$ & Cores \\
\hline 1 & Silty clay, gray to brown, with some nannofossil and foraminifer ooze & Quaternary & 146.9 & 0 & 59 & $\begin{array}{l}\text { 391-1; 391A-1, 2, 3, Section } 1 ; 391 \mathrm{~B}-1 \text { : } \\
391 \mathrm{C}-1 \text { (displaced downhole) }\end{array}$ \\
\hline \multirow[t]{6}{*}{2} & Intraclastic, chalk, mudstone, and carbonate silt & Upper to lower Miocene & 502,1 & 146.9 & 21 & 391A-3, Section 2 through $20 ; 391 \mathrm{C}-2$ \\
\hline & 2a. Calcareous silt, white & Upper Miocene & $(56.6)$ & (146.9) & (14) & 391A-3, 4 , Section 1 \\
\hline & $\begin{array}{l}\text { 2b. Intraclastic chalk, light gray with dark greenish gray clasts. Marly chalk, } \\
\text { light bluish gray with light gray mottles; occurs at top of subunit }\end{array}$ & Middle Miocene & (122.5) & (203.5) & (19) & $391 \mathrm{~A}-4-2$, through $391 \mathrm{~A}$, Section 6 \\
\hline & 2c. Radiolarian mudstone, olive-gray to dark olive-gray & Middle Miocene & (28.5) & $(326.0)$ & (30) & $391 \mathrm{~A}-7$ through 8 \\
\hline & $\begin{array}{l}\text { 2d. Intraclastic chalk, light gray with dark greenish gray clasts; clasts in } \\
\text { basal } 6 \mathrm{~m} \text { include white limestone fragments }\end{array}$ & Middle to lower Miocene & $(171.0)$ & $(354.5)$ & (22) & $391 \mathrm{~A}-9$ through 12 \\
\hline & $\begin{array}{l}\text { 2e. Mudstones, olive-gray, alternating with light gray chalk, intraclastic } \\
\text { near base; intervals with Bouma sequences }\end{array}$ & Lower Miocene & (123.5) & $(525.5)$ & (32) & $391 \mathrm{~A}-13$ through $20 ; 391 \mathrm{C}-2$ \\
\hline \multirow[t]{4}{*}{3} & Claystone & $\begin{array}{l}\text { Upper Cretaceous to } \\
\text { upper Valanginian }\end{array}$ & 352.3 & 649.0 & 13 & $391 \mathrm{~A}-21,391 \mathrm{C}-3$ through 13 \\
\hline & 3a. Variegated claystone & Upper Cretaceous to Albian & $(76.0)$ & $(649.0)$ & (14) & $391 \mathrm{~A}-21 ; 391 \mathrm{C}-3$ through 6 \\
\hline & 3b. Claystone, dark greenish gray, olive-gray, and black; silty stringers & $\begin{array}{l}\text { Upper Cretaceous to upper } \\
\text { Albian }\end{array}$ & $(199.5)$ & (725) & (6) & $391 \mathrm{C}-7$ through 10 \\
\hline & $\begin{array}{l}\text { 3c. Claystone, very dark gray, calcareous, microlaminated; sparse interbeds } \\
\text { of limestone }\end{array}$ & $\begin{array}{l}\text { Aptian and lower Barremian- } \\
\text { upper Valanginian }\end{array}$ & $(76.8)$ & $(924.5)$ & (18) & $391 \mathrm{C}-11$ through 13 \\
\hline \multirow[t]{5}{*}{4} & Limestone (and shale) & $\begin{array}{l}\text { (Barremian?) Hauterivian to } \\
\text { upper Tithonian }\end{array}$ & 322.9 & 1001.3 & 46 & $391 \mathrm{C}-14$ to 45 \\
\hline & $\begin{array}{l}\text { 4a. Limestone, gray to olive-gray; olive gray shale; limestones are in part } \\
\text { quartz sandy with traces of oolite, along with turbidite structures; very } \\
\text { thin black silty shales are cross laminated }\end{array}$ & $\begin{array}{l}\text { Lower Barremian to upper } \\
\text { Valanginian }\end{array}$ & $(122.7)$ & (1001.3) & (20) & $391 \mathrm{C}-14$ through 23 \\
\hline & $\begin{array}{l}\text { 4b. Limestone and shale. Five lithologies: (1) mm-laminated calcilutite, } \\
\text { light gray; ( } 2 \text { bioturbated calcilutite, light bluish gray; ( } 3 \text { massive } \\
\text { calcilutite, shades of brown; (4) black shale; (5) mm-laminated } \\
\text { calcilutite, dark gray }\end{array}$ & $\begin{array}{l}\text { Lower Barremian-upper } \\
\text { Berriasian to lower } \\
\text { Valganian-upper } \\
\text { Berriasian }\end{array}$ & $(95.8)$ & $(1124.0)$ & (59) & $391 \mathrm{C}-24$ through 33 \\
\hline & $\begin{array}{l}\text { 4c. Limestone, blue white to medium bluish green, bioturbated; dark } \\
\text { olive-gray clay as wispy stringers and as rare } 2-3 \mathrm{~cm} \text { intervals }\end{array}$ & $\begin{array}{l}\text { Lower Valangian to upper } \\
\text { Berriasian }\end{array}$ & (37.3) & $(1219.8)$ & (53) & $391 C-34$ through 37 \\
\hline & $\begin{array}{l}\text { 4d. Limestone, white calcilutite, bioturbated; } 1-3 \mathrm{~cm} \text { greenish gray shale } \\
\text { intervals }\end{array}$ & $\begin{array}{l}\text { Lower Berriasian to upper } \\
\text { Tithonian }\end{array}$ & $(67.1)$ & (1257.1) & (39) & $391 \mathrm{C}-38$ through 44 \\
\hline \multirow[t]{3}{*}{5} & Limestone and claystone & Lower Tithonian & 87.8 & 1324.2 & 26 & $391 \mathrm{C}-45$ through 52 \\
\hline & 5a. Limestone, variegated argillaceous calcilutite & Lower Tithonian & (47.0) & $(1324.2)$ & (21) & $391 \mathrm{C}-45$ through 49 \\
\hline & 5b. Calcareous claystone, very dark red; sparsely fossiliferous & Lower Tithonian & $(40.8)$ & (1371.2) & (39) & $391 \mathrm{C}-50$ through 54 \\
\hline
\end{tabular}

In addition to silty clay, unit 1 includes scattered thin $(<$ $9 \mathrm{~cm}$ ) layers of light gray (5Y 7/1) marly nannofossil ooze totaling 3 meters ( $2 \%$ of the unit's thickness). The paucity suggests that unit 1 foraminifers and calcareous nannofossils, along with the low total $\mathrm{CaCO}_{3}$ content, suggests that unit accumulated near the compensation depth of calcium carbonate (CCD) with some contribution by gravity transport from more shallow-water environments.

\section{Unit 2}

Unit 2 was sampled in Holes 391A and 391C (Table 2). In Hole $391 \mathrm{~A}$, its base falls between contiguous Cores 20 and 21 at a sub-bottom depth of 649 meters. In Hole 391C the bottom contact falls within a "washed" interval between Cores 391C-2 and 3. Unit 2 comprises 502.1 meters of carbonate silt, intraclastic chalk and limestone, and terrigenous claystone and mudstone. Constituent particle composition is shown in Table 4. A 56.6-meter-thick interval of carbonate silt in the uppermost part of the unit is unique, both in lithology and in stratigraphic position. This interval is designated sub-unit $2 \mathrm{a}$ and is included in the chalks of Table 4.

Sub-unit 2a: Sub-unit 2a extends from the base of unit 1, 146.9 meters to 203.5 meters sub-bottom. The 56.6-meter bed consists of remarkably uniform white (5Y 8/1 to 8/2) clay-size and silt-size carbonate of uncertain origin and lesser amounts of foraminifers and nannofossils. The average $\mathrm{CaCO}_{3}$ content (LECO determination) is 91 per cent. Sub-unit 2a is less consolidated ("soft" to "stiff") than other sub-units of unit 2 .

The carbonate layers in sub-unit $2 \mathrm{a}$ probably were transported by turbidity flows and deposited above the CCD. A single catastrophic event probably did not produce the entire sub-unit. Although no changes in sedimentation are discernible within the cored parts of sub-unit $2 \mathrm{a}, 51$ meters separate the two cores in which the unit was examined. We do not know what type of gravity transport (turbidity current, debris flow, etc.) was responsible for the deposition and with the exception of a scoured surface in Core 391A-4-1, sub-unit 2 a lacks the grading and cross-lamination usually expected in turbidity-current deposits.

Sub-unit 2b: Sub-unit 2b is largely intraclastic chalk, with 3.7 meters of mottled chalk in its uppermost part and limestone in Section 391A-6-6. The mottled chalk is underlain by $13 \mathrm{~cm}$ of dark greenish gray (5GY 4/1) claystone that contains 7 to 15 per cent terrigenous silt and a few microfossils. The intraclastic chalk contains numerous millimetric to $3-\mathrm{cm}$, evenly distributed, crudely discoidal, well-oriented (horizontally), clasts. The clasts consist of muddy siliceous ooze (Table 4) of three main colors; dark greenish gray (5GY $4 / 1$ to $5 \mathrm{G} 4 / 1$ ), olive-gray (5Y $4 / 2$ ), and 

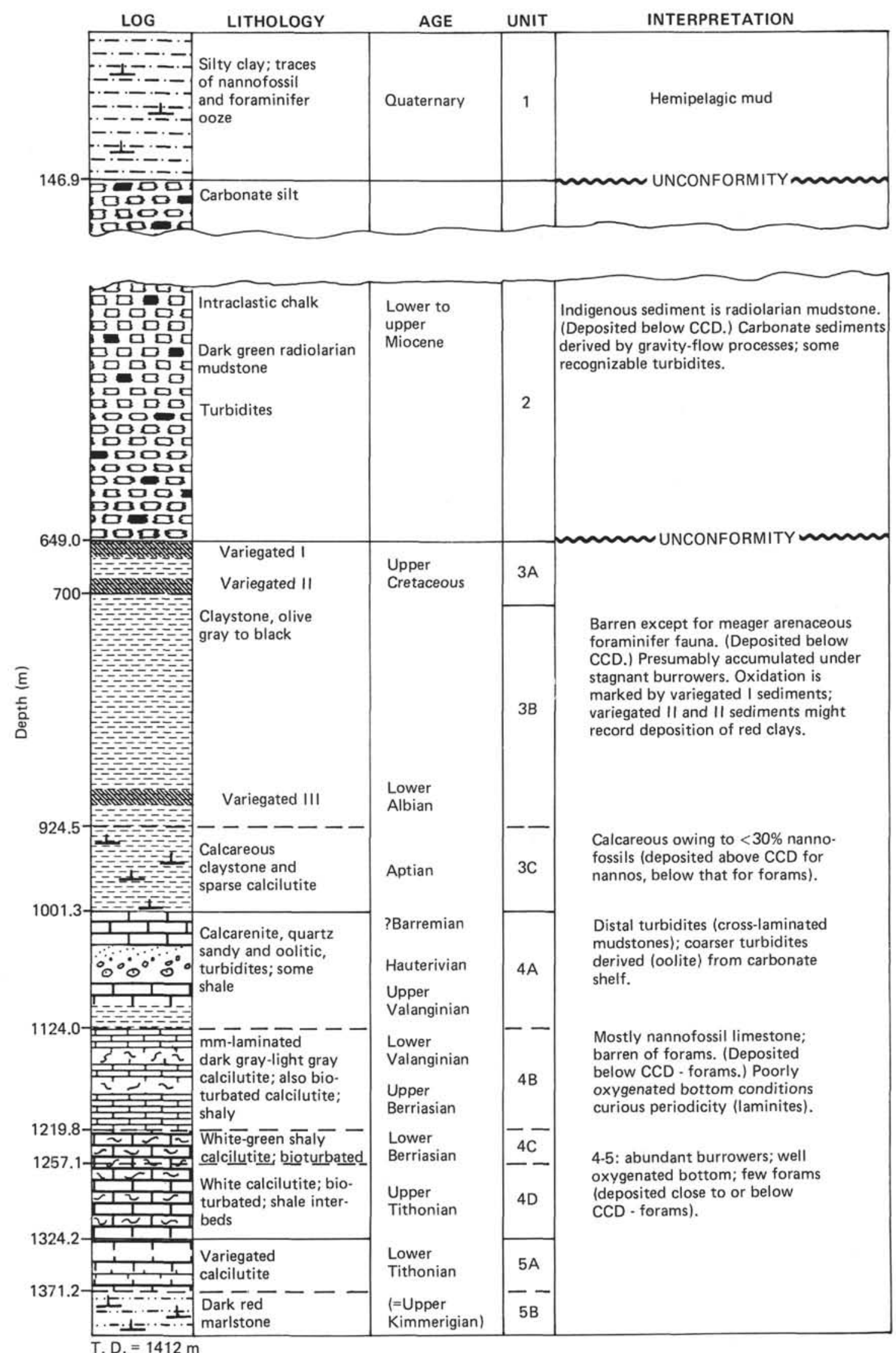

Figure 9. Summary of lithologic units, Site 391. 
DOMINANT LITHOLOGY
SMEAR SLIDE SUMMARY

SITE 391

RARE

391A EXOGENIC AUTHIGENIC-DIAGENIC COBNON = 25.49 DOMINANT $=-50.74$

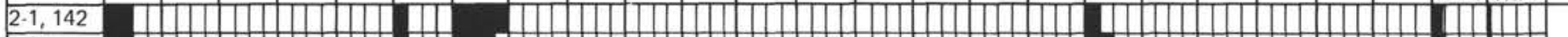

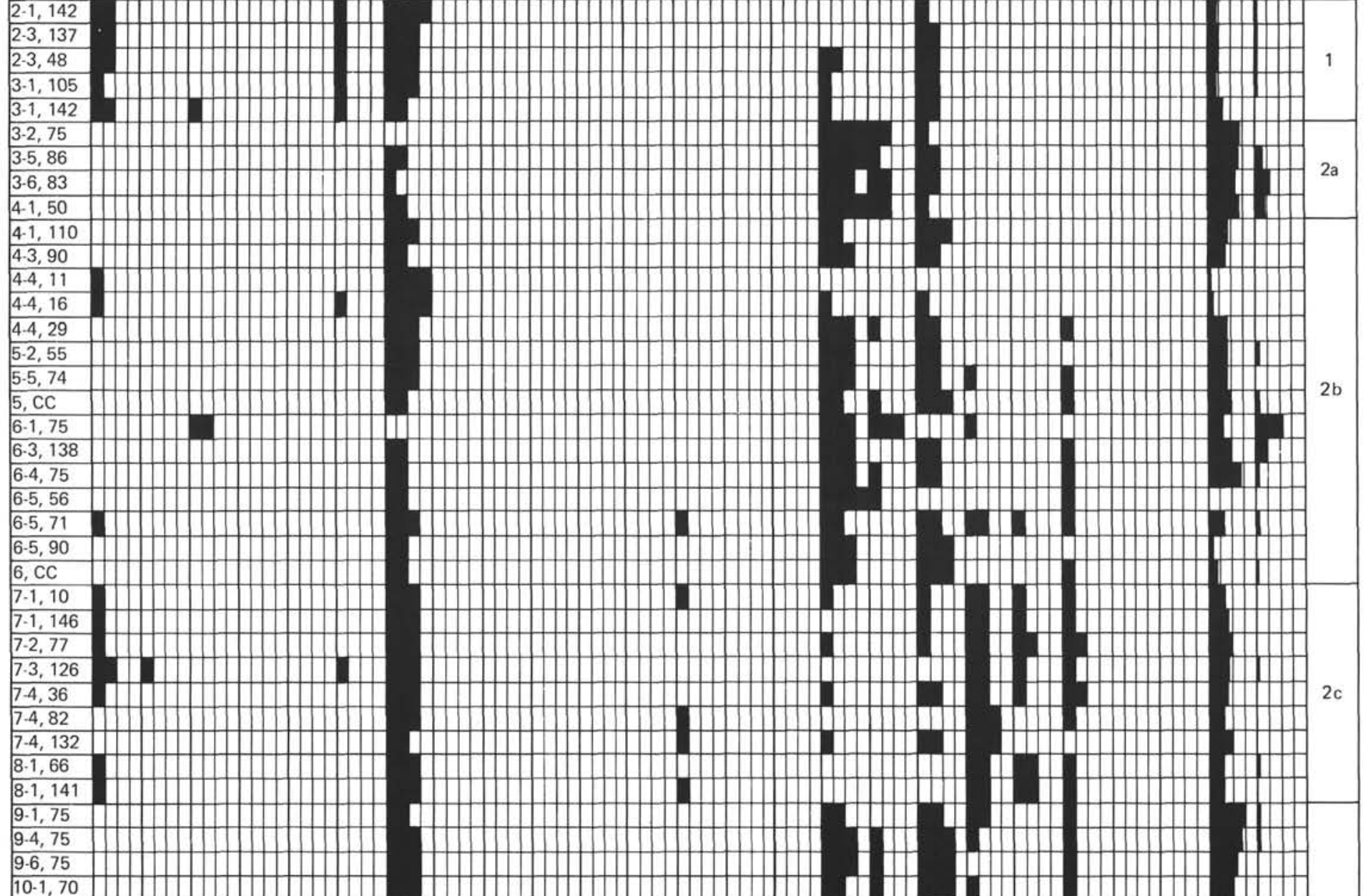

Figure 10. Estimate of major components in dominant lithologies from smear slides, Hole $391 \mathrm{~A}$. 


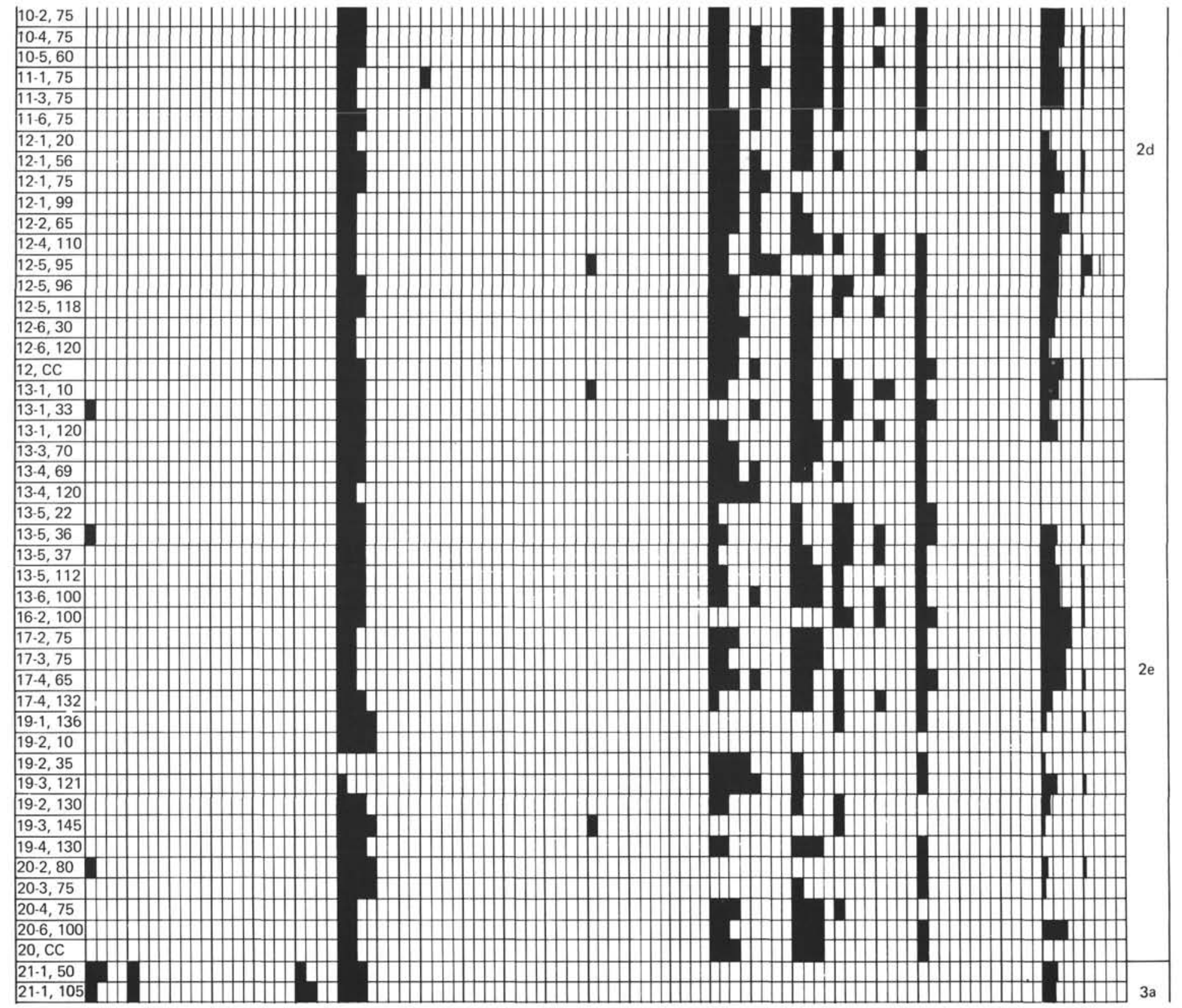

Figure 10. Continued. 


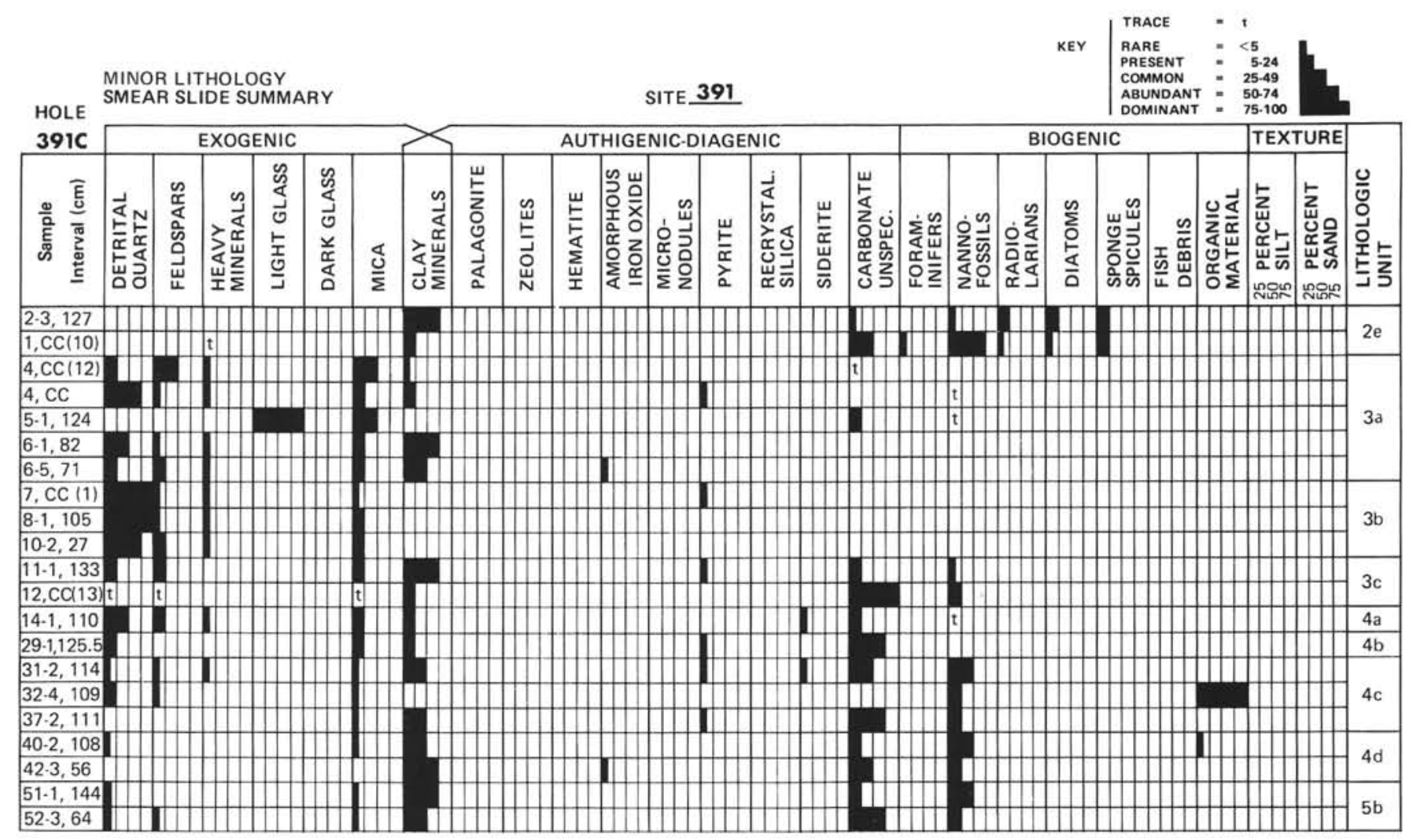

Figure 12. Estimate of major components in minor lithologies, Hole 391C.

TABLE 3

Constituent Particle Composition, Unit 1

\begin{tabular}{cccccccc}
\hline Clay & Quartz & Mica & Unspecified Carbonate & Nannofossils & Foraminifers & Siliceous Fossils & Miscellaneous \\
\hline 60.5 & 8 & 3.6 & 9 & 12.6 & 1.9 & 0.3 & 4 \\
$(22.8)$ & $(4.5)$ & $(3.5)$ & $(15)$ & $(17.7)$ & 1.9 & 0.3 & 4 \\
63.5 & 8 & 3.6 & 7.9 & 10.7 & 1.9 & 4 \\
\hline
\end{tabular}

Note: Average percentages determined on basis of 22 smear-slide analyses (standard deviation in parenthesis), followed by averages adjusted with carbonate "bomb" analyses. Adjustment was made by apportioning total carbonate discrepancy among nannofossils and unspecified carbonate. Complementary adjustment was made in quartz percentage to maintain total carbonate value.

TABLE 4

Constituent Particle Composition of Unit 2

\begin{tabular}{|c|c|c|c|c|c|c|c|}
\hline Lithology & Clay & Quartz & Mica & Unspecified Carbonate & Nannofossils & Foraminifers & Siliceous Fossils \\
\hline $\begin{array}{c}\text { Chalk } \\
\text { (54 samples) }\end{array}$ & $\begin{array}{c}23.8 \\
(11.7) \\
13\end{array}$ & - & - & $\begin{array}{c}44.3 \\
(22.2) \\
50.5\end{array}$ & $\begin{array}{c}24.9 \\
(17.4) \\
28.8\end{array}$ & $\begin{array}{c}3.5 \\
(6.8) \\
3.5\end{array}$ & $\begin{array}{c}3.5 \\
(4.9) \\
3.5\end{array}$ \\
\hline $\begin{array}{c}\text { Clasts } \\
\text { (12 samples) }\end{array}$ & $\begin{array}{c}65.1 \\
(15.2) \\
65.1\end{array}$ & $\begin{array}{l}0.3 \\
0.3\end{array}$ & - & $\begin{array}{c}4.5 \\
(8.5) \\
4.5\end{array}$ & $\begin{array}{c}4.0 \\
(5.4) \\
4.0\end{array}$ & $\begin{array}{l}0.3 \\
0.3\end{array}$ & $\begin{array}{c}25.8 \\
(15.3) \\
25.8\end{array}$ \\
\hline $\begin{array}{l}\text { Claystone } \\
\text { (25 samples) }\end{array}$ & $\begin{array}{c}69.6 \\
(17.8) \\
62.4\end{array}$ & $\begin{array}{c}2.0 \\
(3.5) \\
2.0\end{array}$ & - & $\begin{array}{c}2.9 \\
(5) \\
5.9\end{array}$ & $\begin{array}{c}3.9 \\
(4.6) \\
8.1\end{array}$ & $\begin{array}{l}0.1 \\
0.1\end{array}$ & $\begin{array}{c}20.5 \\
(15.3) \\
20.5\end{array}$ \\
\hline
\end{tabular}

Note: Standard deviation shown in parentheses followed by averages adjusted with carbonate "bomb" analyses.

medium bluish gray (5B 5/1). Siliceous fossils within the clasts are largely radiolarians. The intraclasts were apparently at least partly indurated at the time of their deposition, as indicated by their lack of distortion. In fact, the platy shape of many intraclasts suggests that they may have been somewhat fissile. The radiolarians in the intraclasts are older but within the same biostratigraphic zone as those of the host chalk (see Biostratigraphy). 
Any interpretation of the origin of the intraclastic chalk must take into account four points: (1) the intraclasts "float" in the chalk matrix, (2) the platy intraclasts are oriented nearly horizontally, (3) the lithology of the intraclasts is remarkably uniform, and (4) the age of the intraclasts is essentially the same as that of the host chalk.

The lithologic similarity of the clasts suggests that they were derived from an intra-basinal source - presumably one situated along the path of a gravity-induced current. The host sediment was apparently transported by gravity flow which eroded and incorporated fragments of older siliceous mudstone. This similarity in age of the clasts and the host chalk corroborates the theory of intra-basinal origin for the intraclasts. Also, the lithology of the intraclasts is identical to that of certain Miocene radiolarian mudstones present lower in the section.

Sub-unit 2c: Sub-unit $2 c$ consists of 28.5 meters of dark olive-gray (5Y 3/2) radiolarian mudstone. Megascopically, this sub-unit is structureless. It contains a varied biota of radiolarians (up to $38 \%$ ), sponge spicules, diatoms, and calcareous nannofossils. Total constituent particle composition is given, along with other fine-grained unit 2 rocks, in Table 4 under "Claystone."

Sub-unit 2d: Sub-unit $2 \mathrm{~d}$ comprises intraclastic chalks indistinguishable from those of sub-unit $2 \mathrm{~b}$ and thin $(<8$ $\mathrm{cm}$ ) interbeds of dark olive-gray ( $5 \mathrm{Y} 3 / 2)$ siliceous mudstones similar to those of sub-unit $2 \mathrm{c}$ near the base of the sub-unit. In Core 12, Section 1, the intraclastic chalk lithology grades downward into polymictic conglomeratic chalk (Figure 13). In contrast to the intraclastic chalk, the conglomeratic chalk is marked by the occurrence of varicolored limestone granules (pinkish gray, 5 YR $8 / 1$; light bluish gray, 5B 7/1; olive-brown, 5 Y 4/4), along with the olive-gray siliceous claystone clasts described above. We recognized the following rock types from petrographic analyses of thin sections of the limestone pebbles.

1) Intraclastic-foraminifer lime packstone: includes red algae, echinoderms, and miliolids.

2) Pelletoidal packstone: miliolids, ostracodes, and trace opaline silica.

3) Pelletoidal grainstone: miliolids and mollusks.

Unlike the intraclastic chalks, the conglomeratic chalk includes detritus derived from a shallow-water carbonate platform.

Sub-unit 2e: Sub-unit $2 \mathrm{e}$ is more variable than any of the preceding subdivisions of unit 2 . In addition to lithologies similar to those described from sub-units $2 b$ through $2 d$, sub-unit $2 \mathrm{e}$ includes intervals with erosional bases and partial Bouma sequences indicative of turbidite deposition (Figures 14 and 15). Sub-unit 2e lacks the limestone granules that occur in $2 \mathrm{~d}$, and the claystone clasts are much smaller (millimeter in scale) than those above. An exception to the latter occurs in Core 2 of Hole 391C. This core, on the basis of the interval from which it was cored, fits between Cores 19 and 20 of Hole 391A, but consists of intraclastic chalk indistinguishable from those of sub-units $2 \mathrm{~b}$ and $2 \mathrm{~d}$.

\section{Unit 3}

Unit 3 consists of variegated dark greenish gray and olive-gray, black, and variegated claystones that grade downward into calcareous laminated mudstone and

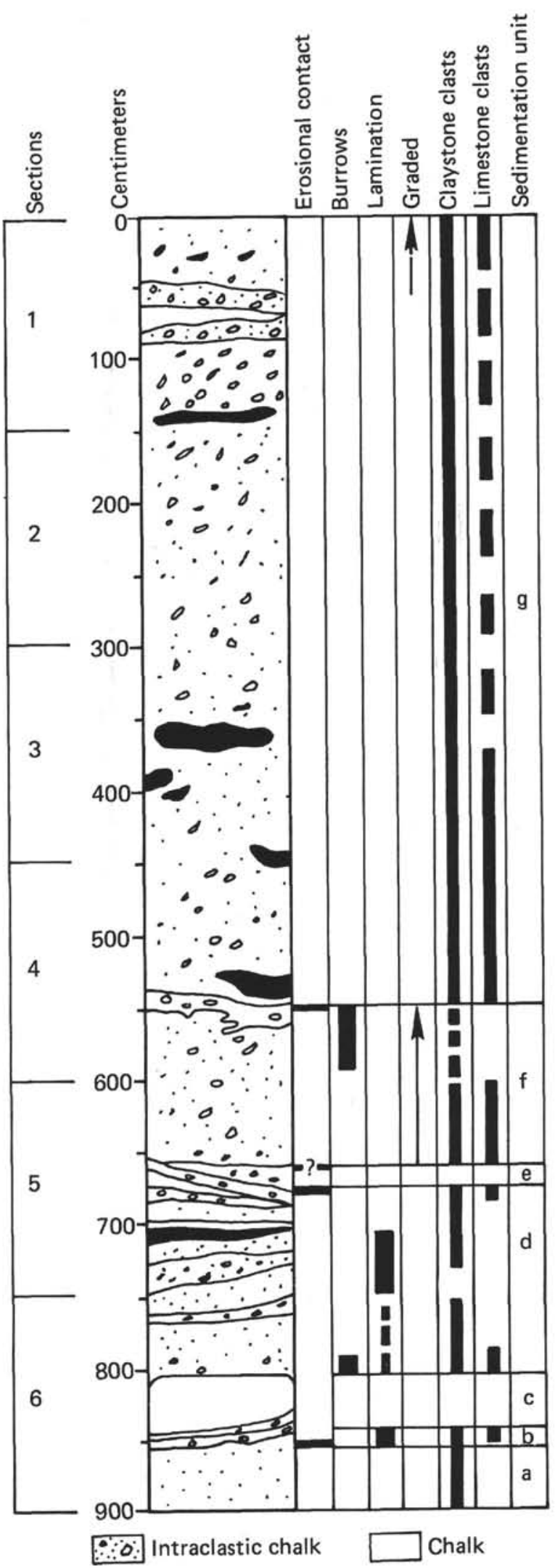

Figure 13. Conglomeratic chalk of sub-unit $2 d$. Grading in upper part and at 5.5 meters might be turbidites. Core 391A-12. 


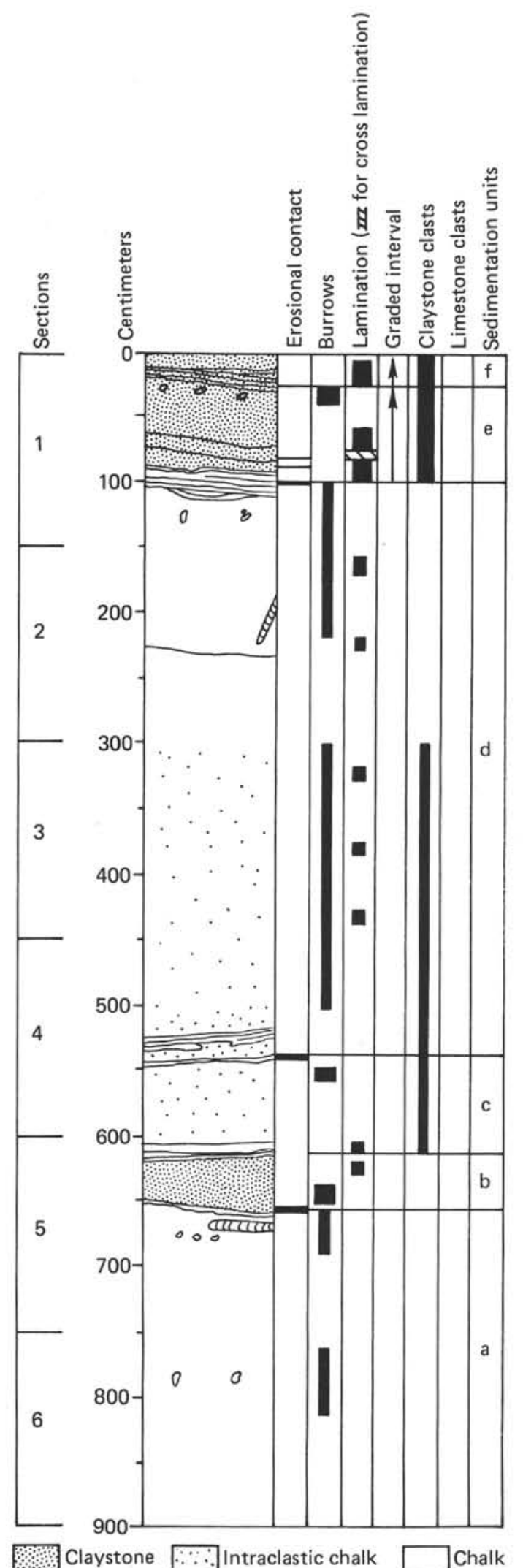

Figure 14. Sub-unit 2e. The two graded beds at the top of the core are probably turbidites. Core 391A-13.

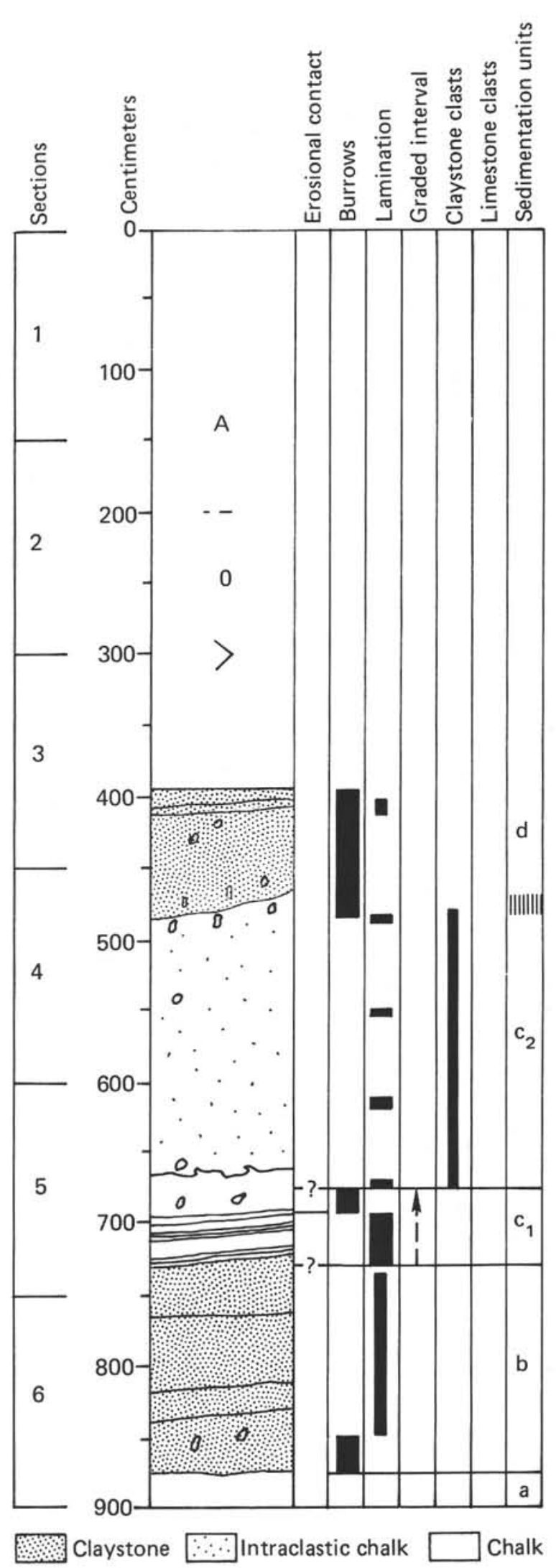

Figure 15. Sub-unit 2e. The beds between 4.9 and 7.2 meters are probably turbidites. Core 391A-19. 
limestone. These three broad subdivisions comprise sub-units 3a, 3b, and 3c. Differences in constituent particle composition are shown in Table 5, and carbonate percentage of limestones and claystones of unit 3 are shown in Table 6.

The limestones of unit 3 appear to be indigenous as they contain no allochthonous gravity-flow debris. The unit was probably deposited in water depths shallower than the carbonate compensation depth for nannofossils.
Sub-unit 3a: Sub-unit 3a consists mainly of variegated claystones of yellowish brown (10YR 5/4), dark brown (7.5YR 4/4), yellowish red (5Y 4/8), dark greenish brown $(2.5 \mathrm{Y} 3 / 2)$, dark gray (2.5Y $3 / 0)$, and light olive-gray ( $5 \mathrm{Y}$ $5 / 2$ ). Variegated claystones occur in Core 21, Sections 2, 5 , 6 of Hole 391A; and in Core 6 of Hole 391C. Similar sediments also occur in Core 10, Sections 2 and 3 of Hole 391C. The variegated intervals record oxidation of bottom sediments that presumably took place during periods of

TABLE 5

Constituent Particle Composition of Site 391 Sub-Units 3a Through 4d

\begin{tabular}{|c|c|c|c|c|c|c|c|}
\hline $\begin{array}{c}\text { Sub-Unit } \\
\text { (No. of Samples) }\end{array}$ & Clay & Quartz & Mica & $\begin{array}{l}\text { Unspecified } \\
\text { Carbonate }\end{array}$ & Nannofossils & Foraminifers & $\begin{array}{l}\text { Siliceous } \\
\text { Fossils }\end{array}$ \\
\hline $\begin{array}{c}3 a+b \\
(37)\end{array}$ & $\begin{array}{c}61.8 \\
(26.2) \\
\text { Plus feldspar: } \\
3.5( \pm 6.3)\end{array}$ & $\begin{array}{c}7.6 \\
(10.1)\end{array}$ & $\begin{array}{c}8.8 \\
(8.5)\end{array}$ & $\begin{array}{c}6.7 \\
(16.9) \\
\text { Plus siderite: } \\
4.6( \pm 12.7)\end{array}$ & 1.8 & - & 0.1 \\
\hline $\begin{array}{l}3 c \\
(10)\end{array}$ & $\begin{array}{l}50.6 \\
(32)\end{array}$ & 0.3 & 0.9 & $\begin{array}{c}22.4 \\
(29) \\
\text { Plus siderite: } \\
2.1\end{array}$ & $\begin{array}{c}22.4 \\
(18.9)\end{array}$ & - & - \\
\hline $\begin{array}{c}4 \mathrm{a} \\
(30\end{array}$ & $\begin{array}{c}33.3 \\
(31.4) \\
\text { Plus feldspar: } \\
1.4( \pm 2.7)\end{array}$ & $\begin{array}{c}6.6 \\
(10.9)\end{array}$ & $\begin{array}{l}1.5 \\
(8.5)\end{array}$ & $\begin{array}{l}48 \\
(35.3)\end{array}$ & $\begin{array}{c}7.4 \\
(9.2)\end{array}$ & 0.7 & - \\
\hline $\begin{array}{l}4 \mathrm{~b} \\
(38)\end{array}$ & $\begin{array}{l}41.9 \\
(26.8)\end{array}$ & $\begin{array}{c}1.3 \\
(3.7)\end{array}$ & $\begin{array}{l}1.6 \\
(2.6)\end{array}$ & $\begin{array}{c}\quad 36.3 \\
(32.4) \\
\text { Plus siderite: } \\
2.8( \pm 6.6)\end{array}$ & $\begin{array}{l}11.9 \\
(9.3)\end{array}$ & - & 0.1 \\
\hline $\begin{array}{l}4 c \\
(9)\end{array}$ & $\begin{array}{c}42.1 \\
(11.1)\end{array}$ & - & 0.1 & $\begin{array}{c}36.1 \\
(17.3)\end{array}$ & $\begin{array}{l}21.7 \\
(9.7)\end{array}$ & - & - \\
\hline $\begin{array}{l}4 d \\
(18)\end{array}$ & $\begin{array}{c}32.8 \\
(19.5)\end{array}$ & 0.1 & 0.2 & $\begin{array}{r}54.3 \\
(23.8\end{array}$ & $\begin{array}{l}11.5 \\
(8.8)\end{array}$ & - & 0.8 \\
\hline
\end{tabular}

Note: Standard deviation shown in parentheses followed by averages adjusted with carbonate "bomb" analysis.

TABLE 6

Calcium Carbonate Contents of Sub-Units 3a Through $5 \mathrm{~b}$ on Basis of Carbonate Bomb Data ${ }^{a}$ (sub-units, except sub-unit $5 \mathrm{~b}$, are collectively divided into specific lithologies)

\begin{tabular}{|c|c|c|c|c|c|}
\hline Sub-Unit & $\begin{array}{l}\text { No. of } \\
\text { Samples }\end{array}$ & $\begin{array}{c}\text { Range } \\
\mathrm{CaCO}_{3}(\%)\end{array}$ & $\begin{array}{c}\text { Average } \\
\mathrm{CaCO}_{3}(\%)\end{array}$ & Lithology & \\
\hline $3 a, 3 b, 3 c$ & $\begin{array}{r}4 \\
10\end{array}$ & $\begin{array}{r}70-95.2 \\
5.1-9.7\end{array}$ & $\begin{array}{r}78.6 \\
7.3\end{array}$ & $\begin{array}{l}\text { Limestones } \\
\text { Claystone }\end{array}$ & \\
\hline $4 \mathrm{a}$ & $\begin{array}{l}5 \\
3 \\
1\end{array}$ & $\begin{array}{c}74.3-97.1 \\
21-32.4 \\
67\end{array}$ & $\begin{array}{l}85 \\
28.1 \\
67\end{array}$ & $\begin{array}{l}\text { Limestone } \\
\text { Calcareous claystone ("shale") } \\
\text { Sandy limestone }\end{array}$ & \\
\hline $4 b$ & $\begin{array}{l}8 \\
5 \\
2\end{array}$ & $\begin{array}{l}79.4-93.1 \\
16-32.5 \\
45.1-55\end{array}$ & $\begin{array}{l}87.3 \\
21.1 \\
50\end{array}$ & $\begin{array}{l}\text { No. } 1,2 \text {, and } 3 \text { limestone types } \\
\text { Calcareous claystone } \\
\text { No. } 5 \text { marly limestone type }\end{array}$ & \\
\hline $4 \mathrm{c}$ & $\begin{array}{l}6 \\
4\end{array}$ & $\begin{array}{l}50.7-68.6 \\
83.9-95.6\end{array}$ & $\begin{array}{l}57 \\
91.7\end{array}$ & $\begin{array}{l}\text { Marly limestone } \\
\text { Limestone }\end{array}$ & \\
\hline $4 d$ & $\begin{array}{l}5 \\
3\end{array}$ & $\begin{array}{l}50.7-61.5 \\
83.9-95.6\end{array}$ & $\begin{array}{l}54.6 \\
93.1\end{array}$ & $\begin{array}{l}\text { Marly limestone } \\
\text { Limestone }\end{array}$ & \\
\hline $5 \mathrm{a}$ & $\begin{array}{l}3 \\
2\end{array}$ & $\begin{array}{l}19.5-25.6 \\
63.4-83.9\end{array}$ & $\begin{array}{l}22.9 \\
73.6\end{array}$ & $\begin{array}{l}\text { Calcareous claystone } \\
\text { Marly limestone and limestone }\end{array}$ & \\
\hline $5 b$ & 5 & $36.6-45.5$ & 41.6 & Calcareous claystone & \\
\hline
\end{tabular}

${ }^{a}$ Calcium carbonate contents were determined on board ship with the carbonate bomb technique. Values are generally higher than those given by the Leco 70-second analyzer (Appendix I). 
retarded rates of sedimentation or erosion and subsequent exposure.

Sub-unit 3b: Sub-unit 3b consists of dark greenish gray (5GY 4/1), olive-gray (5Y 3/2), and black 2.5YR N 2.5) claystones of Hole $391 \mathrm{C}$, Cores 7, 8, 9, and Core 10, Sections 2 and 3 . The claystone contains virtually no fossils (Table 5) which reflects either its accumulation below the $\mathrm{CCD}$ or accumulation at unusually rapid rates. The apparent lack of siliceous fossils, as well as of calcareous fossils, suggests the latter possibility and indicates unsuitable environmental conditions for proliferation or preservation of benthic and planktonic organisms. A sparse foraminifer fauna near the base of sub-unit $3 b$ is of Albian age. Lamination, mottling, and burrowing are common in the sub-unit.

Sub-unit 3c: Sub-unit $3 c$ is an Aptian sequence transitional into the carbonates of unit 4 below. In sub-unit $3 \mathrm{c}$, the claystones are millimeter-laminated and very calcareous, and include thin (few $\mathrm{cm}$ ) interbeds of dark calcilutite.

The carbonate in the gray $(2.5 \mathrm{Y} \mathrm{N} 5 /)$ to black (7.5YR $\mathrm{N} 2.5$ ), claystones comes from the numerous calcareous nannofossils which comprise 15 to 20 per cent of the sediment. Sub-unit $3 \mathrm{c}$ includes three thin $(\sim 1 \mathrm{~cm})$ intervals of cross-laminated mudstones. An ammonite was found in Core 12 , Section 1 , at $133 \mathrm{~cm}$.

\section{Unit 4}

Unit 4 is the most complex unit within the Mesozoic beds of Site 391. It consists of a variety of limestones, mudstones, and shales and is divisible into four sub-units. The upper three record a fairly complete Neocomian (Hauterivian to Berriasian) section; the lowest unit is uppermost Jurassic (Tithonian)).

Sub-unit 4a: Sub-unit $4 \mathrm{a}$ is characterized by limestone and mudstone containing quartz sand and silt. Thin $(1-2 \mathrm{~cm})$ intervals of cross-laminated mudstones (distal turbidites?) are present along with sandy cross-laminated limestones that show partial Bouma sequences (Figure 16). A few coated grains (superficial oolite) are present in some of the sandy limestones. Limestones of sub-unit $4 \mathrm{a}$ are gray (5Y $5 / 1$ ) to olive-gray ( $5 \mathrm{Y} 5 / 2)$, and the mudstones are dark olive-gray (5Y $3 / 2)$ to black (5Y 2.5/1).

Sub-unit 4b: Sub-unit $4 \mathrm{~b}$ consists of four main lithologies, in order of decreasing abundance:

1) Thinly laminated light gray $(5 Y 6 / 1)$ to olive-gray $(5 \mathrm{Y} 5 / 2)$ and dark gray $(2.5 \mathrm{Y} \mathrm{N} / 4)$ to very dark gray $(5 \mathrm{Y}$ 3/1) calcilutite.

2) Light bluish gray (5B 7/1) bioturbated calcilutite.

3) Black (2.5Y N2.5/) to very dark gray (2.5Y N3/) shale.

4) Olive-gray ( $5 Y$ 5/2) massive calcilutite (rare).

The units do no occur in any systematic sequence and we detected no cyclicity.

The laminations of type 1 appear to be about a millimeter thick and are so evenly spaced that they suggest an origin similar to that of varves. However, detailed examination of $21 \mathrm{~cm}$ of typical laminites showed that the "millimeter laminae" are themselves compound and that the actual average is 67 laminations $/ \mathrm{cm}$. The thickness of lamination coupled with a sediment accumulation rate of $2.1 \mathrm{~cm} / 1000$

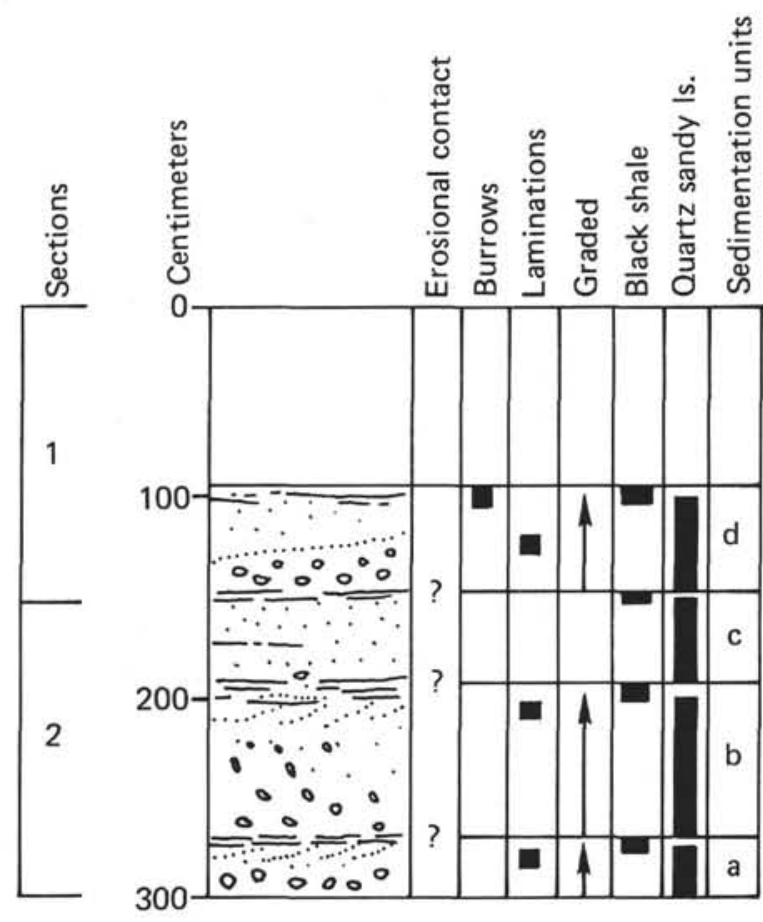

Figure 16. Bouma sequences in limestones of subunit $4 a$ (underlying and overlying rocks not shown). Core 391C-17.

years indicatess a duration of about 7.1 years per lamina. This does not correspond to known climatic cycles. Aptychi are common in the millimeter laminites.

Sub-unit 4c: Sub-unit 4c consists mainly of bioturbated calcilutite like that of lithology 2 in sub-unit 4b. Olive-gray (5Y 4/1) clay occurs both as wispy stringers and as a few 2-3-cm-thick beds. Traces of millimeter-laminated calcilutite like that of lithology 1 of sub-unit $4 \mathrm{~d}$ also occur.

Sub-unit 4d: Sub-unit $4 d$ is similar to $4 c$, but the clay and carbonate are better segregated. The bioturbated calcilutites of sub-unit $4 \mathrm{~d}$ are white (7.5YR N 8) to light bluish gray (5B 7/1). Calcitized radiolarians (calcispheres) are common, and stylolites occur sparsely in this sub-unit. Greenish gray $(5 G 6 / 1)$ to dark green $(5 G 4 / 1)$ shale is present in a few thin (few $\mathrm{cm}$ ) intervals as wispy "partings.,"

\section{Unit 5}

Unit 5 consists of lower Tithonian red limestone and calcareous claystone divisible into two sub-units.

Sub-unit 5a: Sub-unit $5 \mathrm{a}$ is texturally like the white limestone of sub-unit $4 \mathrm{~d}$, but differs markedly in color. The calcilutites of $5 \mathrm{a}$ are pale red $(2.5 \mathrm{YR} 6 / 2,2.5 \mathrm{YR} 4 / 2)$, reddish brown $(2.5 \mathrm{YR} 4 / 4)$, bluish white (5B 9/1), and greenish gray (5GY 6/1). The different colored lithologies are indistinguishable texturally. Dark reddish brown (5YR $3 / 2$ ) calcareous claystone is present in small amounts.

Sub-unit 5b: Sub-unit 5 b is reddish brown (5YR 3/2) calcareous claystone. A few of mollusk fragments (one apparently consisting of nacreous aragonite) and several Phylloceras sp. were found within this sub-unit. We detected a single questionable cross-laminated layer $1-\mathrm{cm}$ 
thick. Calcareous nannofossils, which range up to 30 per cent in sub-unit $5 \mathrm{~b}$ account for most of the $\mathrm{CaCO}_{3}$ content.

\section{SUMMARY}

At Site 391, surface sediments (unit 1) consist of 146.9 meters of Quaternary hemipelagic silty clay with traces of nannofossil and foraminifer ooze. This sequence rests comformably on 502.1 meters of Miocene carbonate gravity-flow deposits and indigenous radiolarian mudstone (unit 2). The Miocene deposits apparently accumulated below the CCD.

Unconformably underlying the Miocene sequence is a 352.3-meter section of variegated and dark Cretaceous claystone (unit 3 ) that becomes progressively more calcareous toward its base. A meager arenaceous foraminifer fauna together with a bountiful nannofossil flora (up to $30 \%$ ) suggests that unit 3 accumulated below the foraminifer CCD, but above the nannofossil CCD. Bottom conditions were apparently somewhat stagnant, but intermittently sufficiently oxygenated to support burrowing organisms. Rapid rates of sediment accumulation probably are responsible for both the dark color of the sediments and the apparent absence of fossils. Three intervals of variegated sediments record retarded sedimentation rates or erosion, and related oxidation of bottom sediments.

Underlying the dark claystone is 122.7 meters of turbidite-bearing limestone, mudstone, and shale (sub-unit 4a). The coarser quartzose turbidites contain oolites derived from a carbonate shelf. Thin intervals of cross-laminated mudstones are distal turbidites.

A 95.8-meter-thick interval of unusual carbonate laminites and bioturbated calcilutites (sub-unit $4 \mathrm{~b}$ ) underlies the turbidites. The laminations (which average 67 per $\mathrm{cm}$ ) appear too regular to have been deposited by bottom currents.

Sub-units $4 \mathrm{c}$ through $5 \mathrm{~b}$ consist of 192.2 meters of lower Berriasian to lower Tithonian calcilutites. The sediments are light gray to varicolored, and this, along with a thoroughly bioturbated fabric, reflects oxygenated bottom conditions. The presence of only a few foraminifers indicates the unit was deposited in water deeper than or close to the foraminifer CCD.

\section{GEOCHEMISTRY}

We had three main objectives in our geochemistry program at Site 391: (1) to sample the Cretaceous black claystones for detailed study of their organic geochemistry, (2) to deterine major cations, $p \mathrm{H}$, alkalinity, salinity, and chlorinity of their interstitial water at approximately 50 -meter intervals, and (3) to determine the presence of gassy sediment.

\section{Organic Geochemistry}

The discovery of Middle to Upper Cretaceous organic carbon-rich "black" sediments in the northwestern (Sites 11-105, 11-101, 43-387); northeastern (Sites 41-367, 41-368, 14-135, 14-138, and 14-140); southwestern (Site 36-327); and southeastern (Sites 40-361, 40-363, 40-364, 40-365) Atlantic Ocean indicates that reducing conditions at or just beneath the sediment-water interface occurred over vast areas of the Atlantic Ocean during Cretaceous time.
The inferrence is further supported by the presence of pyrite, siderite, and fish skeletons and the lack of burrows in these sediments (Site 41-368). Although plant material has been reported in this formation (Site 41-368), preliminary studies of the hydrocarbons and fatty acids in the soluble organic matter is marine organisms, rather than terrestrial plants (Simoneit et al., 1973). Samples were collected at Site 391 for studies of the source, the stage of diagenesis, and the petroleum-bearing potential of the organic matter in the Cretaceous black claystone. Detailed analyses of these samples has been completed by several workers and the results of these studies are presented in Part V (Organic Geochemistry) of this volume.

\section{Interstitial Water Chemistry (Victor Sotelo, analyst)}

Twelve samples from Site 391 were analyzed for $p \mathrm{H}$, alkalinity, salinity, chlorinity, and calcium and magnesium contents. The procedures used were, with minor modification, those of Gieskes (1974) and Gieskes and Lawrence (1976). The data are given in Table 7 and plotted indepth in Figure 17. Sediments below 905 meters are indurated and no samples were taken. The sample from 391B-1-5, 140-150 cm is from Quaternary hemipelagic mud. Those taken between 150 and 600 meters were from Miocene turbidite sediments. The samples taken below 650 meters were all from Cretaceous black carbonaceous claystone; those below 692 meters yielded only enough interstitial water for analysis of salinity, chlorinity, and major cations.

The relationship between $\mathrm{Ca}^{++}$and $\mathrm{Mg}^{++}$at Site 391 is highly irregular (Figure 18), rather than linear as would be expected if the concentrations were controlled by one simple reaction (e.g., the displacement of $\mathrm{Ca}^{++}$by $\mathrm{Mg}^{++}$ during dolomitization). Because of this complexity the $\mathrm{Ca}^{++}$values were recalculated for data from Site 391 using the method of Geiskes (1974) in which the calcium concentration is to a small degree dependent on the $\mathrm{Mg} / \mathrm{Ca}$ ratio in solution.

$$
\begin{aligned}
& \mathrm{Mg}=\left(\mathrm{D}_{\mathrm{t}}-0.9558 \mathrm{Ca} / 1.0087\right) \\
& \mathrm{Ca}=0.9558 \mathrm{Ca}+0.0087 \mathrm{Mg}
\end{aligned}
$$

where

$\mathrm{D}_{\mathrm{t}}=$ total alkaline earths

$\mathrm{Ca}_{\mathrm{t}}=$ calcium titration value .

The Ca values, however, were only slightly changed.

We do not know what mechanisms are responsible for the pore-water concentrations of $\mathrm{Mg}^{++}$and $\mathrm{Ca}^{++}$but the presence of two different sediment types (turbidites and pelagic clay) may account for part of the complex relationship.

\section{Gas}

Expansion of the sediment in one core of the carbonaceous claystones indicated the presence of small amounts of gas in that unit; this was the only occurrence of gas at Site 391.

\section{PHYSICAL PROPERTIES}

Sonic velocity, wet bulk density, water content, and porosity were determined for samples from Holes 391A and $391 \mathrm{C}$ in the Blake-Bahama Basin.

Hole $391 \mathrm{~A}$ was drilled to 658.5 meters sub-bottom in Holocene to Albian sediments, but was abandoned when a 
TABLE 7

Summary of Interstitial Water Data, Site 391

\begin{tabular}{|c|c|c|c|c|c|c|c|}
\hline $\begin{array}{c}\text { Sample } \\
\text { (Interval in } \mathrm{cm} \text { ) }\end{array}$ & $\begin{array}{l}\text { Sub-Bottom } \\
\text { Depth }(\mathrm{m})\end{array}$ & $\mathrm{pH}$ & $\begin{array}{r}\text { Alkalinity } \\
(\mathrm{meg} / \mathrm{kg})\end{array}$ & $\begin{array}{l}\text { Salinity } \\
(\% \circ)\end{array}$ & $\begin{array}{c}\mathrm{Ca}^{++} \\
(\mathrm{mmoles} / 1)\end{array}$ & $\begin{array}{c}\mathrm{Mg}^{++} \\
(\mathrm{mmoles} / 1)\end{array}$ & $\begin{array}{l}\mathrm{Cr}^{-} \\
(\% \circ)\end{array}$ \\
\hline $\begin{array}{l}\text { IAPSO Std } \\
\text { Seawater }\end{array}$ & - & 7.94 & 2.40 & 35.2 & 10.5 & 54.0 & 19.4 \\
\hline $\begin{array}{l}\text { Surface } \\
\text { Seawater }\end{array}$ & - & 8.34 & 2.38 & 36.3 & 10.7 & 54.9 & 19.8 \\
\hline \multicolumn{8}{|l|}{ Hole 391B } \\
\hline $1-5,140-150$ & 7.7 & 7.74 & 7.74 & 35.2 & 9.9 & 49.5 & 19.2 \\
\hline \multicolumn{8}{|l|}{ Hole 391A } \\
\hline $\begin{array}{r}3-4,140-150 \\
4-2,140-150 \\
5-4,140-150 \\
6-4,140-150 \\
10-4,140-150 \\
12-5,140-150 \\
19-1,140-150 \\
21-4,140-150\end{array}$ & $\begin{array}{l}151.7 \\
205.7 \\
265.7 \\
322.7 \\
379.7 \\
476.2 \\
584.2 \\
655.2\end{array}$ & $\begin{array}{l}7.27 \\
7.35 \\
7.46 \\
7.38 \\
7.31 \\
7.20 \\
8.06 \\
-\end{array}$ & $\begin{array}{r}12.55 \\
8.94 \\
7.98 \\
8.53 \\
8.70 \\
10.02 \\
11.97 \\
-\end{array}$ & $\begin{array}{l}34.6 \\
34.6 \\
34.1 \\
34.1 \\
34.4 \\
34.1 \\
35.2 \\
33.6\end{array}$ & $\begin{array}{l}12.0 \\
11.3 \\
11.6 \\
11.3 \\
11.3 \\
12.9 \\
19.4 \\
21.6\end{array}$ & $\begin{array}{l}40.5 \\
39.5 \\
37.6 \\
36.6 \\
34.3 \\
32.8 \\
31.7 \\
34.3\end{array}$ & $\begin{array}{l}20.1 \\
19.2 \\
20.0 \\
20.0 \\
20.4 \\
20.4 \\
20.4 \\
19.8\end{array}$ \\
\hline \multicolumn{8}{|l|}{ Hole 391C } \\
\hline $\begin{array}{l}6-4,0-10 \\
9-2,140-150 \\
10-3,100-110\end{array}$ & $\begin{array}{l}687.3 \\
832.7 \\
900.8\end{array}$ & $\begin{array}{c}8.15 \\
- \\
-\end{array}$ & $\begin{array}{l}- \\
-\end{array}$ & $\begin{array}{l}35.2 \\
35.8 \\
36.0\end{array}$ & $\begin{array}{l}25.1 \\
37.4 \\
40.2\end{array}$ & $\begin{array}{l}34.8 \\
36.9 \\
34.6\end{array}$ & $\begin{array}{l}20.1 \\
20.8 \\
21.1\end{array}$ \\
\hline
\end{tabular}

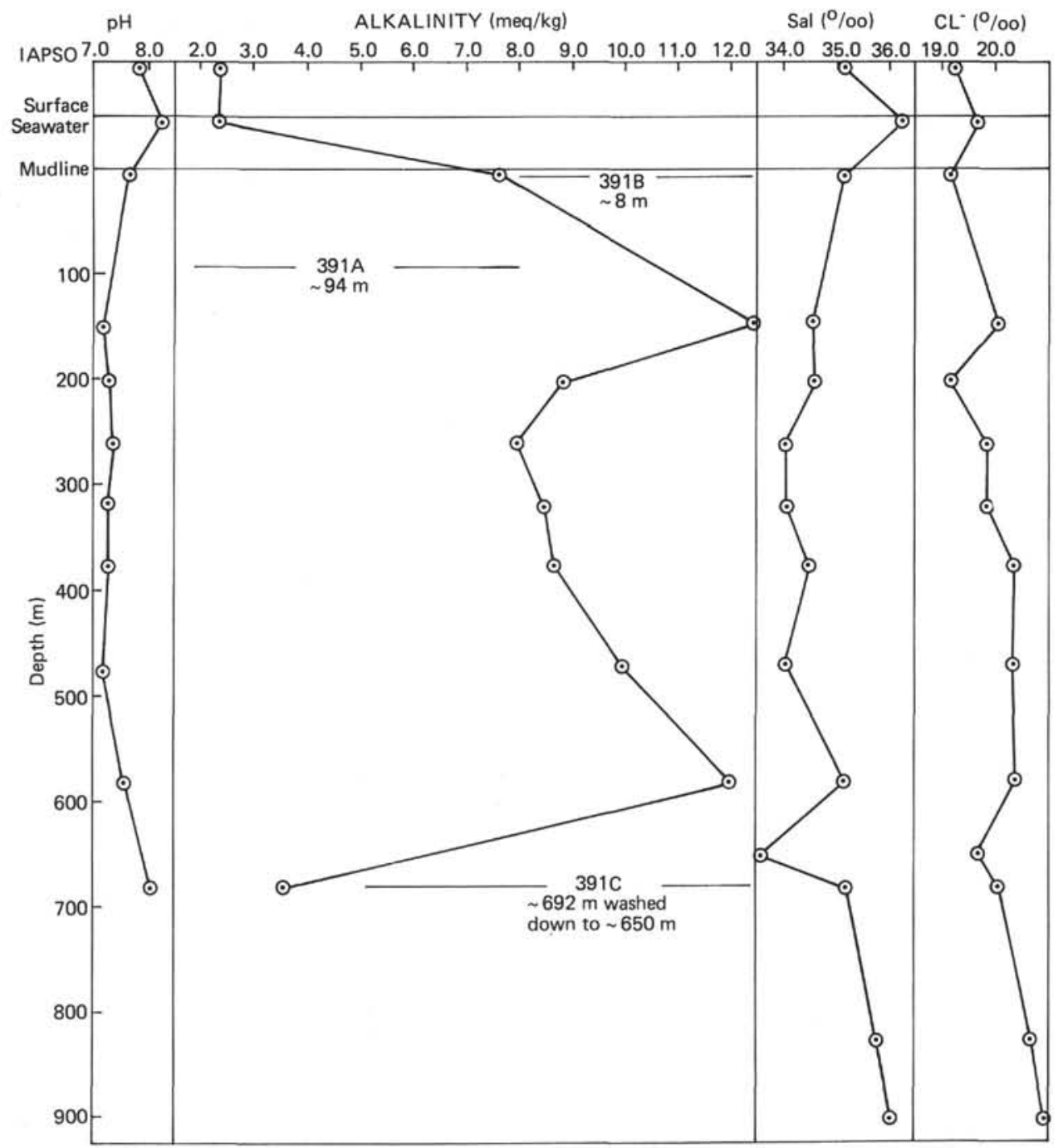

Figure 17. pH, alkalinity, salinity, and chlorinity, Site 391. 


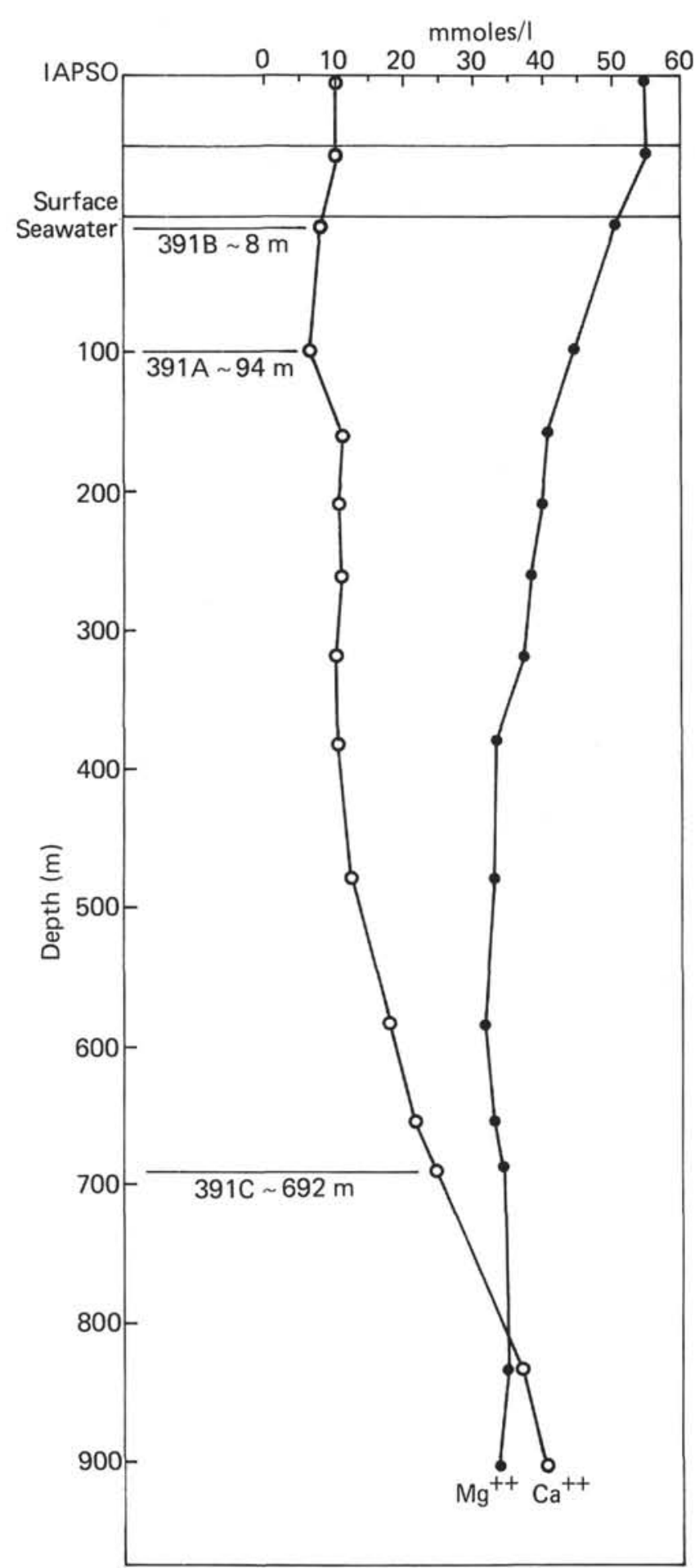

Figure 18. Calcium versus magnesium concentrations versus depth, after Gieskes (1977) method.

core barrel became wedged in the pipe. Hole 391C, drilled when attempts to re-enter $391 \mathrm{~A}$ failed, penetrated to 1412 meters sub-bottom and extended the section to lower Tithonian rocks.

Five major lithologic units (comprising 15 sub-units) and six seismic horizons were recognized from the cored interval. The seismic horizons closely correspond to the lithologic boundaries. The physical properties data are related to "acoustic units" which are mainly defined by the seismic horizons. In one case (unit V), the seismic interval was subdivided into two sub-units, parallel to lithologic boundaries, to isolate properties of somewhat different rocks. (See Figure 24 in correlation of seismic Reflection Profile with Drilling Results.)

\section{Sonic Velocity and Impedance}

We determined sonic velocities using the Hamilton Frame Velocimeter; the procedure is described in Boyce (1973). Accuracy of the technique is \pm 2 per cent and precision of the velocimeter was verified with 10 repeated measurements each of lucite and brass standards. Measurements were made at $5.0 \mathrm{microsec} / \mathrm{cm}$ on split sediment sections. We measured velocities parallel to bedding in the upper unconsolidated sediments of Hole 391A (above Core 13), and perpendicular to bedding in the firm to hard sediments from the lower part of the hole. Both parallel and perpendicular velocities were measured (126 comparable measurements) in the hard chalk, limestone, mudstone, and claystone of Hole 391C. Generally, velocities measured parallel to bedding were about 6.8 per cent lower than those measured to bedding.

Impendance is defined as sonic velocity times density and is recorded for samples were both velocity and density measurements were made from the same or adjacent samples. We determined wet bulk density by "syringe" and "chunk" techniques as described below. We used velocities measured perpendicular to bedding in the impedance calculations where available; otherwise we used values measured parallel to bedding. Sonic velocity and impedance values are given on Table 8 and average values for each acoustic unit are shown on Table 9. Figure 19 is a plot of impedance and velocity versus depth.

Velocity and impedance increase with depth to the base of acoustic unit III (base of intraclastic limestone at $649 \mathrm{~m}$ sub-bottom). A jump in velocity occurs at the base of unit I between unconsolidated calcareous silt and clay, and hard intraclastic chalk. We detected no sharp break between units II and III although this boundary corresponds to a seismic horizon at $0.32 \mathrm{sec}$ (two-way reflection time). Within unit III, however, at about 500 meters sub-bottom a slight velocity reduction occurs. This falls at the boundary between lithologic sub-units $2 \mathrm{~d}$ (limestone with clay and limestone clasts) and $2 \mathrm{e}$ (sequence of alternating mudstones and chalks).

There are but few data points for acoustic units IVA (upper boundary is horizon $A$ ) and IVB (lower boundary is horizon $\beta$ ). Velocities, however, appear to be somewhat, though perhaps not significantly, higher in the upper part of the unit (Albian claystone) and show a velocity inversion in the lower part of the unit (Aptian silty calcareous claystone).

Velocities and impedance in the Cretaceous gray laminated and bioturbated limestones (= acoustic unit VA) are markedly higher than in overylying unit IVB. This break falls at horizon $\beta$. There is also a distinct break between VA and the underlying white (Tithonian) limestone (= acoustic unit VB) in which velocities perpendicular to bedding average $3.34 \mathrm{~km} / \mathrm{sec}$ - the highest of the cored interval. 
TABLE 8

Sonic Velocity and Impedance Measurements, Site 391

\begin{tabular}{|c|c|c|c|c|c|c|}
\hline $\begin{array}{c}\text { Sample } \\
\text { (Interval in (m)) }\end{array}$ & $\begin{array}{l}\text { Depth in } \\
\text { Hole (m) }\end{array}$ & $\begin{array}{l}\text { Velocity } \\
(\mathrm{km} / \mathrm{sec})\end{array}$ & $\begin{array}{c}\text { Impedance } \\
\left(\mathrm{g} / \mathrm{cm}^{2} \sec \times 10^{5}\right)\end{array}$ & $\begin{array}{c}\text { Lithologic } \\
\text { Unit }\end{array}$ & $\begin{array}{l}\text { Acoustic } \\
\text { Unit }\end{array}$ & Lithology \\
\hline \multicolumn{7}{|l|}{ Hole 391A } \\
\hline $1-2,105.0$ & 88.55 & 1.49 (in liner) & 2.16 & 1 & I & Silty clay \\
\hline $1-2,124.0$ & 88.74 & 1.49 (in liner) & & 1 & I & Silty clay \\
\hline $1-5,14.0$ & 92.14 & 1.49 (in liner) & & 1 & I & Silty clay \\
\hline $1-5,90.0$ & 92.90 & 1.49 (in liner) & & 1 & I & Silty clay \\
\hline $1-6,13.0$ & 93.63 & 1.52 (in liner) & & 1 & I & Silty clay \\
\hline $1-6,76.0$ & 94.26 & 1.52 (in liner) & 2.63 & 1 & I & Silty clay \\
\hline $1-6,110.0$ & 94.60 & 1.52 (in liner) & & 1 & I & Silty clay \\
\hline $4-2,37.0$ & 204.37 & 1.70 (in liner) & & $2 \mathrm{~b}$ & II & Marly chalk \\
\hline $4-2,93.5$ & 204.93 & 1.62 (in liner) & 3.09 & $2 \mathrm{~b}$ & II & Marly chalk \\
\hline $4-2,132.5$ & 205.33 & 1.70 (in liner) & & $2 \mathrm{~b}$ & II & Marly chalk \\
\hline $5-1,27.0$ & 260.17 & 1.72 (in liner) & & $2 \mathrm{~b}$ & II & Intraclastic marly chalk \\
\hline $5-1,106.0$ & 260.96 & 1.79 (in liner) & & $2 \mathrm{~b}$ & II & Intraclastic marly chalk \\
\hline $5-2,34.0$ & 261.74 & 1.71 (in liner) & & $2 \mathrm{~b}$ & II & Intraclastic marly chalk \\
\hline $5-2,90.0$ & 262.30 & 1.69 (in liner) & & $2 b$ & II & Intraclastic marly chalk \\
\hline $5-3,42.0$ & 263.32 & 1.70 (in liner) & & $2 \mathrm{~b}$ & II & Intraclastic marly chalk \\
\hline $5-3,94.0$ & 263.84 & 1.68 (in liner) & & $2 \mathrm{~b}$ & II & Intraclastic marly chalk \\
\hline $5-4,56.0$ & 264.96 & 1.78 (in liner) & & $2 \mathrm{~b}$ & II & Intraclastic marly chalk \\
\hline $5-4,112.0$ & 265.52 & 1.87 (in liner) & & $2 b$ & II & Intraclastic marly chalk \\
\hline $5-5,75.0$ & 266.65 & 1.85 (in liner) & & $2 b$ & II & Intraclastic marly chalk \\
\hline $5-6,68.0$ & 268.08 & 1.82 (in liner) & & $2 \mathrm{~b}$ & II & Intraclastic marly chalk \\
\hline $6-1,30.0$ & 316.80 & 1.81 (in liner) & & $2 \mathrm{~b}$ & II & Intraclastic marly chalk \\
\hline $6-1,100.0$ & 317.50 & 1.73 (in liner) & & $2 b$ & II & Intraclastic marly chalk \\
\hline $6-1,107.0$ & 317.57 & 1.75 (in liner) & & $2 b$ & II & Intraclastic marly chalk \\
\hline $6-2,36.0$ & 318.36 & 1.75 (in liner) & 3.29 & $2 \mathrm{~b}$ & II & Intraclastic marly chalk \\
\hline $6-2,116.0$ & 319.16 & 1.81 (in liner) & & $2 b$ & II & Intraclastic marly chalk \\
\hline $6-3,48.0$ & 319.98 & 1.83 (in liner) & & $2 \mathrm{~b}$ & II & Intraclastic marly chalk \\
\hline $6-3,86.0$ & 320.36 & 1.85 (in liner) & & $2 b$ & II & Intraclastic marly chalk \\
\hline $6-4,70.0$ & 321.70 & 2.24 (in liner) & & $2 b$ & II & Intraclastic marly chalk \\
\hline $6-4,76.0$ & 321.76 & 2.12 (in liner) & 4.24 & $2 b$ & II & Intraclastic marly chalk \\
\hline $6-4,119.0$ & 322.19 & 1.92 (in liner) & & $2 \mathrm{~b}$ & II & Intraclastic marly chalk \\
\hline $6-5,106.0$ & 323.56 & 2.03 (in liner) & & $2 b$ & II & Intraclastic marly chalk \\
\hline $7-1,11.0$ & 326.11 & 1.66 (in liner) & & $2 \mathrm{c}$ & II & Radiolarian mudstone \\
\hline $9-1,32.0$ & 355.32 & 1.79 (in liner) & & $2 d$ & III & Intraclastic marly chalk \\
\hline $9-1,69.0$ & 355.69 & 1.83 (in liner) & & $2 d$ & III & Intraclastic marly chalk \\
\hline $9-2,36.0$ & 356.86 & 1.77 (in liner) & & $2 \mathrm{~d}$ & III & Intraclastic marly chalk \\
\hline $9-2,119.0$ & 357.69 & 1.75 (in liner) & & $2 \mathrm{~d}$ & III & Intraclastic marly chalk \\
\hline $9-3,43.0$ & 358.43 & 1.78 (in liner) & & $2 \mathrm{~d}$ & III & Intraclastic marly chalk \\
\hline $9-3,120.0$ & 359.20 & 1.78 (in liner) & & $2 \mathrm{~d}$ & III & Intraclastic marly chalk \\
\hline $9-4,53.0$ & 360.03 & 1.85 (in liner) & & $2 \mathrm{~d}$ & III & Intraclastic marly chalk \\
\hline $9-4,127.0$ & 360.77 & 1.79 (in liner) & & $2 \mathrm{~d}$ & III & Intraclastic marly chalk \\
\hline $9-5,80.0$ & 361.80 & 1.81 (in liner) & & $2 \mathrm{~d}$ & III & Intraclastic marly chalk \\
\hline $9-6,83.0$ & 363.33 & 1.78 (in liner) & & $2 \mathrm{~d}$ & III & Intraclastic marly chalk \\
\hline $10-1,26.0$ & 374.16 & 1.87 (out of liner) & & $2 \mathrm{~d}$ & III & Intraclastic marly chalk \\
\hline $10-1,145.0$ & 375.35 & $1.87^{\mathrm{a}}$ (out of liner) & & $2 \mathrm{~d}$ & III & Intraclastic marly chalk \\
\hline $10-2,98.0$ & 376.38 & $1.85^{\mathrm{a}}$ (out of liner) & & $2 \mathrm{~d}$ & III & Intraclastic marly chalk \\
\hline $10-3,7.0$ & 376.97 & $1.85^{\mathrm{a}}$ (out of liner) & & $2 \mathrm{~d}$ & III & Intraclastic marly chalk \\
\hline $10-4,73.0$ & 379.13 & $1.87 \mathrm{a}$ (out of liner) & 3.42 & $2 \mathrm{~d}$ & III & Intraclastic marly chalk \\
\hline $10-5,17.0$ & 380.07 & $1.85^{\mathrm{a}}$ (out of liner) & & $2 \mathrm{~d}$ & III & Intraclastic marly chalk \\
\hline $10-5,123.0$ & 381.13 & 1.89 (out of liner) & & $2 d$ & III & Intraclastic marly chalk \\
\hline $10-6,17.0$ & 381.57 & 1.86 (out of liner) & 3.44 & $2 \mathrm{~d}$ & III & Intraclastic marly chalk \\
\hline $11-1,109.0$ & 413.09 & 1.91 (out of liner) & & $2 d$ & III & Intraclastic marly chalk \\
\hline $11-2,10.0$ & 413.60 & 1.90 (out of liner) & & $2 \mathrm{~d}$ & III & Intraclastic marly chalk \\
\hline $11-2,10.0$ & 413.60 & 1.91 (out of liner) & & $2 \mathrm{~d}$ & III & Intraclastic marly chalk \\
\hline $11-2,90.0$ & 414.40 & 1.94 (out of liner) & 3.57 & $2 d$ & III & Intraclastic marly chalk \\
\hline $11-2,113.0$ & 414.63 & 1.94 (out of liner) & & $2 \mathrm{~d}$ & III & Intraclastic marly chalk \\
\hline $11-3,10.0$ & 415.10 & 1.95 (out of liner) & & $2 d$ & III & Intraclastic marly chalk \\
\hline $11-3,127.0$ & 416.27 & 1.92 (out of liner) & & $2 \mathrm{~d}$ & III & Intraclastic marly chalk \\
\hline $11-4,132.0$ & 417.82 & 1.95 (out of liner) & & $2 \mathrm{~d}$ & III & Intraclastic marly chalk \\
\hline $11-5,21.0$ & 418.21 & 1.98 (out of liner) & & $2 d$ & III & Intraclastic marly chalk \\
\hline $11-6,82.0$ & 420.32 & 1.98 (out of liner) & & $2 \mathrm{~d}$ & III & Intraclastic marly chalk \\
\hline $11-6,133.0$ & 420.83 & 1.92 (out of liner) & & $2 \mathrm{~d}$ & III & Intraclastic marly chalk \\
\hline $12-2,147.0$ & 471.97 & 2.09 (out of liner) & & $2 \mathrm{~d}$ & III & Intraclastic marly chalk \\
\hline $12-6,63.0$ & 477.13 & $2.36^{\mathrm{a}}$ (out of liner) & & $2 \mathrm{~d}$ & III & Intraclastic marly chalk \\
\hline $13-1,11.0$ & 526.11 & $1.65^{a}$ (out of liner) & & $2 \mathrm{e}$ & III & Siliceous mudstone \\
\hline $13-1,11.0$ & 526.11 & $1.67^{\mathrm{a}}$ (out of liner) & & $2 \mathrm{e}$ & III & Siliceous mudstone \\
\hline $13-1,20.0$ & 526.20 & $1.77 \mathrm{a}$ (out of liner) & & $2 \mathrm{e}$ & III & Siliceous mudstone \\
\hline
\end{tabular}


TABLE 8 - Continued

\begin{tabular}{|c|c|c|c|c|c|c|}
\hline $\begin{array}{c}\text { Sample } \\
\text { (Interval in }(\mathrm{m}))\end{array}$ & $\begin{array}{l}\text { Depth in } \\
\text { Hole (m) }\end{array}$ & $\begin{array}{l}\text { Velocity } \\
(\mathrm{km} / \mathrm{sec})\end{array}$ & $\begin{array}{c}\text { Impedance } \\
\left(\mathrm{g} / \mathrm{cm}^{2} \sec \times 10^{5}\right)\end{array}$ & $\begin{array}{l}\text { Lithologic } \\
\text { Unit }\end{array}$ & $\begin{array}{l}\text { Acoustic } \\
\text { Unit }\end{array}$ & Lithology \\
\hline $13-2,8.0$ & 527.58 & $1.91^{\mathrm{a}}$ (out of liner) & 3.63 & $2 \mathrm{e}$ & III & Nannofossil chalk \\
\hline $13-3,7.0$ & 529.07 & $1.93^{\mathrm{a}}$ (out of liner) & & $2 \mathrm{e}$ & III & Nannofossil chalk \\
\hline $13-4,9.0$ & 530.59 & $1.98^{\mathrm{a}}$ (out of liner) & & $2 \mathrm{e}$ & III & Marly chalk \\
\hline $13-5,145.0$ & 533.45 & $1.94^{\mathrm{a}}$ (out of liner) & & $2 \mathrm{e}$ & III & Marly nannofossil chalk \\
\hline $13-6,8.0$ & 533.58 & $1.90^{\mathrm{a}}$ (out of liner) & & $2 \mathrm{e}$ & III & Marly nannofossil chalk \\
\hline $16-1,122.0$ & 555.22 & $1.77^{\mathrm{a}}$ (out of liner) & & $2 \mathrm{e}$ & III & Siliceous mudstone \\
\hline $16-2,95.0$ & 556.45 & $1.70^{\mathrm{a}}$ (out of liner) & 2.67 & $2 \mathrm{e}$ & III & Siliceous mudstone \\
\hline $17-1,142.0$ & 569.92 & $1.94^{\mathrm{a}}$ (out of liner) & & $2 \mathrm{e}$ & III & Nannofossil chalk \\
\hline $17-2,72.0$ & 570.72 & $1.98^{\mathrm{a}}$ (out of liner) & 3.90 & $2 \mathrm{e}$ & III & Nannofossil chalk \\
\hline $17-3,83.0$ & 572.33 & $1.91^{\mathrm{a}}$ (out of liner) & & $2 \mathrm{e}$ & III & Nannofossil chalk \\
\hline $17-4,77.0$ & 573.77 & $3.33^{\mathrm{a}}$ (out of liner) & 7.63 & $2 \mathrm{e}$ & III & Chalk \\
\hline $17-4,77.0$ & 573.77 & $3.34^{\mathrm{a}}$ (out of liner) & & $2 \mathrm{e}$ & III & Chalk \\
\hline $17-4,82.0$ & 573.82 & $3.68^{\mathrm{a}}$ (out of liner) & & $2 \mathrm{e}$ & III & Chalk \\
\hline $17-4,125.0$ & 574.25 & $1.75^{\mathrm{a}}$ (out of liner) & & $2 \mathrm{e}$ & III & Siliceous mudstone \\
\hline $19-2,144.0$ & 585.44 & $2.01^{\text {a }}$ (out of liner) & 3.94 & $2 \mathrm{e}$ & III & Chalk \\
\hline $19-3,143.0$ & 586.93 & $1.91^{\mathrm{a}}$ (out of liner) & & $2 \mathrm{e}$ & III & Claystone \\
\hline $19-4,37.0$ & 587.37 & $1.91^{\mathrm{a}}$ (out of liner) & & $2 \mathrm{e}$ & III & Claystone \\
\hline $19-4,134.0$ & 588.34 & $1.93^{\mathrm{a}}$ (out of liner) & & $2 \mathrm{e}$ & III & Marly nannofossil chalk \\
\hline $20-1,133.0$ & 640.83 & $1.69^{\mathrm{a}}$ (out of liner) & & $2 \mathrm{e}$ & III & Claystone \\
\hline $20-2,124.0$ & 642.24 & $1.75^{\mathrm{a}}$ (out of liner) & & $2 \mathrm{e}$ & III & Claystone \\
\hline $20-3,106.0$ & 643.56 & $1.69 \mathrm{a}$ (out of liner) & 2.79 & $2 \mathrm{e}$ & III & Claystone \\
\hline $20-4,140.0$ & 645.40 & $2.05^{\mathrm{a}}$ (out of liner) & & $2 \mathrm{e}$ & III & Nannofossil chalk \\
\hline $20-5,139.0$ & 646.89 & $2.06^{\mathrm{a}}$ (out of liner) & 4.18 & $2 \mathrm{e}$ & III & Nannofossil chalk \\
\hline \multicolumn{7}{|l|}{ Hole 391B } \\
\hline $1-2,58.0$ & 2.28 & 1.47 (in liner) & & 1 & I & Clay \\
\hline $1-2,119.5$ & 2.90 & 1.47 (in liner) & 2.19 & 1 & I & Clay \\
\hline $1-4,24.0$ & 4.94 & 1.48 (in liner) & 2.41 & 1 & I & Clay \\
\hline $1-4,123.5$ & 5.94 & 1.48 (in liner) & & 1 & I & Clay \\
\hline $1-6,32.0$ & 8.02 & 1.48 (in liner) & 2.44 & 1 & I & Foraminifer-nannofossil ooze \\
\hline $1-6,95.0$ & 8.65 & 1.47 (in liner) & & 1 & 1 & Silty clay \\
\hline \multicolumn{7}{|l|}{ Hole 391C } \\
\hline $2-1,143.0$ & 612.83 & 1.82 (out of liner) & & $2 \mathrm{e}$ & III & Intraclastic chalk \\
\hline $2-1,143.0$ & 612.83 & $1.81^{\mathrm{a}}$ (out of liner) & 3.35 & $2 \mathrm{e}$ & III & Intraclastic chalk \\
\hline $2-2,140.0$ & 614.30 & $1.85^{\mathrm{a}}$ (out of liner) & & $2 \mathrm{e}$ & III & Intraclastic chalk \\
\hline $2-2,140.0$ & 614.30 & 1.86 (out of liner) & & $2 \mathrm{e}$ & III & Intraclastic chalk \\
\hline $2-3,142.0$ & 615.82 & $1.84^{\mathrm{a}}$ (out of liner) & 3.42 & $2 \mathrm{e}$ & III & Intraclastic chalk \\
\hline $2-3,142.0$ & 615.82 & 1.84 (out of liner) & & $2 \mathrm{e}$ & III & Intraclastic chalk \\
\hline $2-4,12.0$ & 616.02 & $1.84^{\mathrm{a}}$ (out of liner) & & $2 \mathrm{e}$ & III & Intraclastic chalk \\
\hline $2-4,12.0$ & 616.02 & 1.87 (out of liner) & & $2 \mathrm{e}$ & III & Intraclastic chalk \\
\hline $2-5,135.0$ & 618.75 & $1.82^{\mathrm{a}}$ (out of liner) & 3.39 & $2 \mathrm{e}$ & III & Intraclastic chalk \\
\hline $2-5,135.0$ & 618.75 & 1.85 (out of liner) & & $2 \mathrm{e}$ & III & Intraclastic chalk \\
\hline $2-6,8.0$ & 618.98 & $1.81^{\mathrm{a}}$ (out of liner) & & $2 \mathrm{e}$ & III & Intraclastic chalk \\
\hline $2-6,8.0$ & 618.98 & 1.84 (out of liner) & & $2 \mathrm{e}$ & III & Intraclastic chalk \\
\hline $4-1,140.0$ & 669.40 & $1.85^{\mathrm{a}}$ (out of liner) & 3.63 & $3 \mathrm{a}$ & IV & Sandy silt \\
\hline $4-1,140.0$ & 669.40 & 1.87 (out of liner) & & $3 a$ & IV & Sandy silt \\
\hline $9-1,40.0$ & 839.40 & $2.27^{\mathrm{a}}$ (out of liner) & 5.88 & $3 b$ & IV & Claystone \\
\hline $9-1,40.0$ & 839.40 & 2.36 (out of liner) & & $3 \mathrm{~b}$ & IV & Claystone \\
\hline $9-2,62.0$ & 841.12 & $2.20^{\mathrm{a}}$ (out of liner) & & $3 \mathrm{~b}$ & IV & Marly limestone \\
\hline $9-2,62.0$ & 841.12 & 2.47 (out of liner) & & $3 b$ & IV & Marly limestone \\
\hline $11-1,42.0$ & 924.92 & $1.84^{\mathrm{a}}$ (out of liner) & 3.77 & $3 \mathrm{c}$ & IV & Calcareous claystone \\
\hline $11-1,42.0$ & 924.92 & 1.98 (out of liner) & & $3 \mathrm{c}$ & IV & Calcareous claystone \\
\hline $11-2,91.0$ & 926.91 & $2.01^{\mathrm{a}}$ (out of liner) & & $3 \mathrm{c}$ & IV & Calcareous claystone \\
\hline $11-2,91.0$ & 926.91 & 2.62 (out of liner) & & $3 \mathrm{c}$ & IV & Calcareous claystone \\
\hline $11-3,46.0$ & 927.96 & 1.97 (out of liner) & & $3 \mathrm{c}$ & IV & Calcareous claystone \\
\hline $11-3,46.0$ & 927.96 & $2.31^{\mathrm{a}}$ (out of liner) & & $3 \mathrm{c}$ & IV & Calcareous claystone \\
\hline $12-1,140.5$ & 954.81 & $2.12^{\mathrm{a}}$ (out of liner) & 4.41 & $3 \mathrm{c}$ & IV & Nannofossil limestone \\
\hline $12-1,140.5$ & 954.81 & 1.91 (out of liner) & & $3 \mathrm{c}$ & IV & Nannofossil limestone \\
\hline $14-2,93.0$ & 1002.93 & $1.88^{a}$ (out of liner) & 3.91 & $4 a$ & VA & Limestone \\
\hline $14-2,93.0$ & 1002.93 & 2.18 (out of liner) & & $4 a$ & VA & Limestone \\
\hline $14-3,64.0$ & 1004.14 & $4.47^{\mathrm{a}}$ (out of liner) & & $4 a$ & VA & Marly limestone \\
\hline $14-3,64.0$ & 1004.14 & 4.51 (out of liner) & & $4 a$ & VA & Marly limestone \\
\hline $15-1,81.0$ & 1010.81 & $2.09^{\mathrm{a}}$ (out of liner) & 4.70 & $4 a$ & VA & Marly limestone \\
\hline $15-1,81.0$ & 1010.81 & 2.47 (out of liner) & & $4 a$ & VA & Marly limestone \\
\hline $15-2,137.0$ & 1012.87 & $2.07^{a}$ (out of liner) & & $4 a$ & VA & Marly limestone \\
\hline $15-2,137.0$ & 1012.87 & 2.21 (out of liner) & & $4 a$ & VA & Marly limestone \\
\hline $15-3,2.0$ & 1013.02 & $2.54^{\mathrm{a}}$ (out of liner) & 5.99 & $4 a$ & VA & Marly limestone \\
\hline $15-3,2.0$ & 1013.02 & 3.04 (out of liner) & & $4 a$ & VA & Marly limestone \\
\hline
\end{tabular}


TABLE 8 - Continued

\begin{tabular}{|c|c|c|c|c|c|c|}
\hline $\begin{array}{c}\text { Sample } \\
\text { (Interval in }(\mathrm{m}))\end{array}$ & $\begin{array}{l}\text { Depth in } \\
\text { Hole }(\mathrm{m})\end{array}$ & $\begin{array}{l}\text { Velocity } \\
(\mathrm{km} / \mathrm{sec})\end{array}$ & $\begin{array}{c}\text { Impedance } \\
\left(\mathrm{g} / \mathrm{cm}^{2} \sec \times 10^{5}\right)\end{array}$ & $\begin{array}{c}\text { Lithologic } \\
\text { Unit }\end{array}$ & $\begin{array}{l}\text { Acoustic } \\
\text { Unit }\end{array}$ & Lithology \\
\hline $15-3,40.0$ & 1013.40 & $5.43^{\mathrm{a}}$ (out of liner) & & $4 a$ & VA & Marly limestone \\
\hline $15-3,40.0$ & 1013.40 & 5.17 (out of liner) & & $4 a$ & VA & Marly limestone \\
\hline $16-1,118.0$ & 1020.68 & $2.03^{\mathrm{a}}$ (out of liner) & & 4a & VA & Marly limestone \\
\hline $16-1,118.0$ & 1020.68 & 2.25 (out of liner) & & $4 \mathrm{a}$ & VA & Marly limestone \\
\hline $16-2,90.0$ & 1021.90 & $2.09^{a}$ (out of liner) & 4.39 & $4 \mathrm{a}$ & VA & Marly limestone \\
\hline $16-2,90.0$ & 1021.90 & 2.57 (out of liner) & & $4 a$ & VA & Marly limestone \\
\hline $16-3,129.0$ & 1023.79 & $4.53^{\mathrm{a}}$ (out of liner) & & $4 \mathrm{a}$ & VA & Sandy siltstone \\
\hline $16-3,129.0$ & 1023.79 & 4.61 (out of liner) & & $4 a$ & VA & Sandy siltstone \\
\hline $16-4,92.0$ & 1024.92 & $1.47 \mathrm{a}$ (out of liner) & 3.23 & $4 a$ & VA & Sandy siltstone \\
\hline $16-4,92.0$ & 1024.92 & 2.48 (out of liner) & & $4 a$ & VA & Sandy siltstone \\
\hline $17-1,123.0$ & 1030.23 & $3.61^{\mathrm{a}}$ (out of liner) & & $4 a$ & VA & Sandy limestone \\
\hline $17-1,123.0$ & 1030.23 & 3.64 (out of liner) & & $4 a$ & VA & Sandy limestone \\
\hline $17-2,83.0$ & 1031.33 & $4.87^{a}$ (out of liner) & & $4 a$ & VA & Sandy limestone \\
\hline $17-2,83.0$ & 1031.33 & 4.77 (out of liner) & & $4 \mathrm{a}$ & VA & Sandy limestone \\
\hline $17-2,138.0$ & 1031.88 & $5.06^{\mathrm{a}}$ (out of liner) & & $4 a$ & VA & Sandy limestone \\
\hline $17-2,138.0$ & 1031.88 & 5.10 (out of liner) & & $4 a$ & VA & Sandy limestone \\
\hline $21-4,84.0$ & 1091.34 & $2.19^{\mathrm{a}}$ (out of liner) & & $4 a$ & VA & Calcareous claystone \\
\hline $21-4,84.0$ & 1091.34 & 2.46 (out of liner) & & $4 a$ & VA & Calcareous claystone \\
\hline $24-2,107.5$ & 1126.58 & 2.83 (out of liner) & & $4 \mathrm{~b}$ & VA & Limestone \\
\hline $24-2,107.5$ & 1126.58 & $2.15^{a}$ (out of liner) & 4.86 & $4 b$ & VA & Limestone \\
\hline $24-4,101.0$ & 1129.51 & 2.27 (out of liner) & & $4 b$ & VA & Limestone \\
\hline $24-4,101.0$ & 1129.51 & $1.97 \mathrm{a}$ (out of liner) & 4.29 & $4 \mathrm{~b}$ & VA & Limestone \\
\hline $24-6,105.5$ & 1132.56 & 2.30 (out of liner) & & $4 b$ & VA & Claystone \\
\hline $24-6,105.5$ & 1132.56 & $2.19^{\mathrm{a}}$ (out of liner) & & $4 b$ & VA & Claystone \\
\hline $25-1,137.0$ & 1134.87 & 4.20 (out of liner) & & $4 \mathrm{~b}$ & VA & Limestone \\
\hline $25-1,137.0$ & 1134.87 & $4.15^{\mathrm{a}}$ (out of liner) & 10.42 & $4 \mathrm{~b}$ & VA & Limestone \\
\hline $25-2,88.0$ & 1135.88 & $3.23^{\mathrm{a}}$ (out of liner) & & $4 b$ & VA & Limestone \\
\hline $25-2,88.0$ & 1135.88 & 3.74 (out of liner) & & $4 b$ & VA & Limestone \\
\hline $25-3,102.0$ & 1137.52 & $2.43^{\mathrm{a}}$ (out of liner) & 5.35 & $4 \mathrm{~b}$ & VA & Limestone \\
\hline $25-3,102.0$ & 1137.52 & 2.92 (out of liner) & & $4 \mathrm{~b}$ & VA & Limestone \\
\hline $25-4,142.0$ & 1139.42 & $3.29^{\mathrm{a}}$ (out of liner) & & $4 \mathrm{~b}$ & VA & Limestone \\
\hline $25-4,142.0$ & 1139.42 & 3.64 (out of liner) & & $4 b$ & VA & Limestone \\
\hline $26-1,112.0$ & 1144.12 & $2.19^{\mathrm{a}}$ (out of liner) & & $4 b$ & VA & Limestone \\
\hline $26-1,112.0$ & 1144.12 & 2.47 (out of liner) & & $4 \mathrm{~b}$ & VA & Limestone \\
\hline $26-2,49.0$ & 1144.99 & $3.67^{a}$ (out of liner) & & $4 b$ & VA & Limestone \\
\hline $26-2,49.0$ & 1144.99 & 3.85 (out of liner) & & $4 \mathrm{~b}$ & VA & Limestone \\
\hline $26-3,104.0$ & 1147.04 & $2.52^{\mathrm{a}}$ (out of liner) & & $4 \mathrm{~b}$ & VA & Limestone \\
\hline $26-3,104.0$ & 1147.04 & 2.96 (out of liner) & & $4 \mathrm{~b}$ & VA & Limestone \\
\hline $26-4,106.0$ & 1148.56 & $3.48^{a}$ (out of liner) & 4.79 & $4 b$ & VA & Limestone \\
\hline $26-4,106.0$ & 1148.56 & 3.70 (out of liner) & & $4 \mathrm{~b}$ & VA & Limestone \\
\hline $27-1,140.0$ & 1153.90 & $4.45^{\mathrm{a}}$ (out of liner) & & $4 \mathrm{~b}$ & VA & Limestone \\
\hline $27-1,140.0$ & 1153.90 & 4.45 (out of liner) & & $4 b$ & VA & Limestone \\
\hline $27-2,49.0$ & 1154.49 & $3.86^{\mathrm{a}}$ (out of liner) & 9.42 & $4 \mathrm{~b}$ & VA & Limestone \\
\hline $27-2,49.0$ & 1154.49 & 3.87 (out of liner) & & $4 \mathrm{~b}$ & VA & Limestone \\
\hline $27-2,138.0$ & 1155.38 & $2.65^{a}$ (out of liner) & & $4 \mathrm{~b}$ & VA & Limestone \\
\hline $27-2,138.0$ & 1155.38 & 3.23 (out of liner) & & $4 b$ & VA & Limestone \\
\hline $27-3,16.0$ & 1155.66 & $3.82^{\mathrm{a}}$ (out of liner) & & $4 b$ & VA & Limestone \\
\hline $27-3,16.0$ & 1155.66 & 4.02 (out of liner) & & $4 \mathrm{~b}$ & VA & Limestone \\
\hline $27-4,92.0$ & 1157.92 & $2.33^{\mathrm{a}}$ (out of liner) & 5.36 & $4 \mathrm{~b}$ & VA & Limestone \\
\hline $27-4,92.0$ & 1157.92 & 3.12 (out of liner) & & $4 b$ & VA & Limestone \\
\hline $28-2,128.0$ & 1164.78 & $3.17^{\mathrm{a}}$ (out of liner) & 7.58 & $4 b$ & VA & Limestone \\
\hline $28-2,128.0$ & 1164.78 & 3.75 (out of liner) & & $4 \mathrm{~b}$ & VA & Limestone \\
\hline $28-2,148.0$ & 1164.98 & $2.65^{\mathrm{a}}$ (out of liner) & & $4 b$ & VA & Limestone \\
\hline $28-2,148.0$ & 1164.98 & 3.12 (out of liner) & & $4 \mathrm{~b}$ & VA & Limestone \\
\hline $28-3,55.0$ & 1165.55 & $2.61^{\mathrm{a}}$ (out of liner) & & $4 \mathrm{~b}$ & VA & Claystone \\
\hline $28-3,55.0$ & 1165.55 & 3.08 (out of liner) & & $4 \mathrm{~b}$ & VA & Claystone \\
\hline $28-4,119.0$ & 1167.69 & $2.42^{\mathrm{a}}$ (out of liner) & 5.44 & $4 \mathrm{~b}$ & VA & Limestone \\
\hline $28-4,119.0$ & 1167.69 & 2.84 (out of liner) & & $4 b$ & VA & Limestone \\
\hline $29-1,100.0$ & 1172.50 & 2.98 (out of liner) & & $4 \mathrm{~b}$ & VA & Limestone \\
\hline $29-1,100.0$ & 1172.50 & $2.63^{\mathrm{a}}$ (out of liner) & & $4 \mathrm{~b}$ & VA & Limestone \\
\hline $29-2,36.0$ & 1173.36 & 2.69 (out of liner) & & $4 b$ & VA & Limestone \\
\hline $29-2,36.0$ & 1173.36 & $2.31^{\mathrm{a}}$ (out of liner) & & $4 b$ & VA & Limestone \\
\hline $29-3,30.0$ & 1174.80 & 3.44 (out of liner) & & $4 b$ & VA & Limestone \\
\hline $29-3,30.0$ & 1174.80 & $2.97^{\mathrm{a}}$ (out of liner) & 6.89 & $4 \mathrm{~b}$ & VA & Limestone \\
\hline $29-4,72.0$ & 1176.72 & 2.66 (out of liner) & & $4 \mathrm{~b}$ & VA & Limestone \\
\hline $29-4,72.0$ & 1176.72 & $2.28^{\mathrm{a}}$ (out of liner) & & $4 b$ & VA & Limestone \\
\hline $29-5,99.0$ & 1178.49 & $3.84^{\mathrm{a}}$ (out of liner) & & $4 b$ & VA & Limestone \\
\hline $29-5,99.0$ & 1178.49 & 3.30 (out of liner) & & $4 \mathrm{~b}$ & VA & Limestone \\
\hline $30-1,137.0$ & 1182.37 & $2.84^{\mathrm{a}}$ (out of liner) & & $4 \mathrm{~b}$ & VA & Limestone \\
\hline
\end{tabular}


TABLE 8 - Continued

\begin{tabular}{|c|c|c|c|c|c|c|}
\hline $\begin{array}{c}\text { Sample } \\
\text { (Interval in }(\mathrm{m}))\end{array}$ & $\begin{array}{l}\text { Depth in } \\
\text { Hole }(\mathrm{m})\end{array}$ & $\begin{array}{l}\text { Velocity } \\
(\mathrm{km} / \mathrm{sec})\end{array}$ & $\begin{array}{c}\text { Impedance } \\
\left(\mathrm{g} / \mathrm{cm}^{2} \sec \times 10^{5}\right)\end{array}$ & $\begin{array}{l}\text { Lithologic } \\
\text { Unit }\end{array}$ & $\begin{array}{l}\text { Acoustic } \\
\text { Unit }\end{array}$ & Lithology \\
\hline $30-1,137.0$ & 1182.37 & 3.27 (out of liner) & & $4 \mathrm{~b}$ & VA & Limestone \\
\hline $30-2,33.0$ & 1182.83 & $2.33^{\mathrm{a}}$ (out of liner) & & $4 b$ & VA & Limestone \\
\hline $30-2,33.0$ & 1182.83 & 2.59 (out of liner) & & $4 b$ & VA & Limestone \\
\hline $30-3,16.0$ & 1184.16 & $2.08^{a}$ (out of liner) & & $4 b$ & VA & Limestone \\
\hline $30-3,16.0$ & 1184.16 & 2.43 (out of liner) & & $4 \mathrm{~b}$ & VA & Limestone \\
\hline $30-4,17.0$ & 1185.67 & $3.51^{\mathrm{a}}$ (out of liner) & & $4 \mathrm{~b}$ & VA & Limestone \\
\hline $30-4,17.0$ & 1185.67 & 3.75 (out of liner) & & $4 \mathrm{~b}$ & VA & Limestone \\
\hline $31-1,116.0$ & 1191.66 & $3.41^{\mathrm{a}}$ (out of liner) & & $4 \mathrm{~b}$ & VA & Clayey limestone \\
\hline $31-1,116.0$ & 1191.66 & 3.79 (out of liner) & & $4 \mathrm{~b}$ & VA & Clayey limestone \\
\hline $31-2,104.0$ & 1193.04 & $2.29^{\mathrm{a}}$ (out of liner) & 5.08 & $4 \mathrm{~b}$ & VA & Clayey limestone \\
\hline $31-2,104.0$ & 1193.04 & 2.63 (out of liner) & & $4 b$ & VA & Clayey limestone \\
\hline $31-3,35.0$ & 1193.85 & $3.40^{\mathrm{a}}$ (out of liner) & 8.09 & $4 b$ & VA & Clayey limestone \\
\hline $31-4,29.0$ & 1195.29 & $2.30^{\mathrm{a}}$ (out of liner) & 5.15 & $4 \mathrm{~b}$ & VA & Clayey limestone \\
\hline $31-4,29.0$ & 1195.29 & 2.67 (out of liner) & & $4 b$ & VA & Clayey limestone \\
\hline $31-5,68.0$ & 1197.18 & $2.33^{\mathrm{a}}$ (out of liner) & & $4 \mathrm{~b}$ & VA & Clayey limestone \\
\hline $31-6,84.0$ & 1198.84 & $3.21^{\mathrm{a}}$ (out of liner) & 7.54 & $4 \mathrm{~b}$ & VA & Clayey limestone \\
\hline $31-6,84.0$ & 1198.84 & 3.59 (out of liner) & & $4 b$ & VA & Clayey limestone \\
\hline $32-1,144.0$ & 1201.44 & $2.73^{\mathrm{a}}$ (out of liner) & & $4 \mathrm{~b}$ & VA & Clayey limestone \\
\hline $32-1,144.0$ & 1201.44 & 3.06 (out of liner) & & $4 \mathrm{~b}$ & VA & Clayey limestone \\
\hline $32-2,61.0$ & 1202.11 & $3.12^{\mathrm{a}}$ (out of liner) & 7.55 & $4 b$ & VA & Clayey limestone \\
\hline $32-2,61.0$ & 1202.11 & 3.41 (out of liner) & & $4 \mathrm{~b}$ & VA & Clayey limestone \\
\hline $32-3,60.0$ & 1203.60 & $3.24^{\mathrm{a}}$ (out of liner) & 7.74 & $4 \mathrm{~b}$ & VA & Clayey limestone \\
\hline $32-3,60.0$ & 1203.60 & 3.66 (out of liner) & & $4 b$ & VA & Clayey limestone \\
\hline $32-4,145.0$ & 1205.95 & $3.52^{\mathrm{a}}$ (out of liner) & 8.41 & $4 \mathrm{~b}$ & VA & Clayey limestone \\
\hline $32-4,145.0$ & 1205.95 & 3.08 (out of liner) & & $4 \mathrm{~b}$ & VA & Clayey limestone \\
\hline $33-1,96.0$ & 1210.46 & $4.05^{\mathrm{a}}$ (out of liner) & 10.17 & $4 \mathrm{~b}$ & VA & Limestone \\
\hline $33-1,96.0$ & 1210.46 & 3.84 (out of liner) & & $4 b$ & VA & Limestone \\
\hline $33-2,52.0$ & 1211.52 & $2.70^{\mathrm{a}}$ (out of liner) & & $4 b$ & VA & Clayey limestone \\
\hline $33-2,52.0$ & 1211.52 & 2.98 (out of liner) & & $4 \mathrm{~b}$ & VA & Clayey limestone \\
\hline $33-3,37.0$ & 1212.87 & $3.02^{\mathrm{a}}$ (out of liner) & 7.13 & $4 \mathrm{~b}$ & VA & Clayey limestone \\
\hline $33-3,37.0$ & 1212.87 & 3.34 (out of liner) & & $4 b$ & VA & Clayey limestone \\
\hline $34-1,92.0$ & 1219.92 & $3.00^{\mathrm{a}}$ (out of liner) & & $4 \mathrm{~b}$ & VA & Clayey limestone \\
\hline $34-1,92.0$ & 1219.92 & 3.23 (out of liner) & & $4 \mathrm{c}$ & VA & Clayey limestone \\
\hline $34-2,137.0$ & 1221.87 & $2.79^{\mathrm{a}}$ (out of liner) & 6.64 & $4 c$ & VA & Clayey limestone \\
\hline $34-2,137.0$ & 1221.87 & 2.99 (out of liner) & & $4 \mathrm{c}$ & VA & Clayey limestone \\
\hline $34-3,53.0$ & 1222.53 & $3.40^{\mathrm{a}}$ (out of liner) & 8.26 & $4 c$ & VA & Clayey limestone \\
\hline $34-3,53.0$ & 1222.53 & 3.52 (out of liner) & & $4 \mathrm{c}$ & VA & Clayey limestone \\
\hline $34-4,88.0$ & 1224.38 & $2.90^{\mathrm{a}}$ (out of liner) & 6.90 & $4 \mathrm{c}$ & VA & Clayey limestone \\
\hline $34-4,88.0$ & 1224.38 & 3.07 (out of liner) & & $4 \mathrm{c}$ & VA & Clayey limestone \\
\hline $35-1,92.0$ & 1229.42 & $3.11^{\mathrm{a}}$ (out of liner) & 7.53 & $4 \mathrm{c}$ & VA & Clayey limestone \\
\hline $35-1,92.0$ & 1229.42 & 3.32 (out of liner) & & $4 \mathrm{c}$ & VA & Clayey limestone \\
\hline $35-2,123.0$ & 1231.23 & $2.59^{\mathrm{a}}$ (out of liner) & 6.01 & $4 \mathrm{c}$ & VA & Clayey limestone \\
\hline $35-2,123.0$ & 1231.23 & 2.82 (out of liner) & & $4 \mathrm{c}$ & VA & Clayey limestone \\
\hline $35-3,30.0$ & 1231.80 & $2.70^{\mathrm{a}}$ (out of liner) & 6.43 & $4 \mathrm{c}$ & VA & Clayey limestone \\
\hline $35-3,30.0$ & 1231.80 & 3.00 (out of liner) & & $4 \mathrm{c}$ & VA & Clayey limestone \\
\hline $35-4,98.0$ & 1233.98 & $3.45^{\mathrm{a}}$ (out of liner) & & $4 c$ & VA & Clayey limestone \\
\hline $35-4,98.0$ & 1233.98 & 3.59 (out of liner) & & $4 \mathrm{c}$ & VA & Clayey limestone \\
\hline $36-1,94.0$ & 1238.94 & $3.30^{\mathrm{a}}$ (out of liner) & & $4 c$ & VA & Clayey limestone \\
\hline $36-1,94.0$ & 1238.94 & 3.47 (out of liner) & & $4 \mathrm{c}$ & VA & Clayey limestone \\
\hline $36-2,25.0$ & 1239.75 & $2.57^{\mathrm{a}}$ (out of liner) & 5.89 & $4 \mathrm{c}$ & VA & Clayey limestone \\
\hline $36-2,25.0$ & 1239.75 & 3.09 (out of liner) & & $4 c$ & VA & Clayey limestone \\
\hline $36-3,82.0$ & 1241.82 & $3.06^{\mathrm{a}}$ (out of liner) & ' & $4 c$ & VA & Clayey limestone \\
\hline $36-3,82.0$ & 1241.82 & 3.25 (out of liner) & & $4 \mathrm{c}$ & VA & Clayey limestone \\
\hline $36-4,93.0$ & 1243.43 & $3.03^{a}$ (out of liner) & & $4 \mathrm{c}$ & VA & Clayey limestone \\
\hline $36-4,93.0$ & 1243.43 & 3.32 (out of liner) & & $4 c$ & VA & Clayey limestone \\
\hline $36-5,50.0$ & 1244.50 & 2.44 (out of liner) & & $4 \mathrm{c}$ & VA & Clayey limestone \\
\hline $36-5,50.0$ & 1244.50 & $2.79^{\mathrm{a}}$ (out of liner) & 6.50 & $4 c$ & VA & Clayey limestone \\
\hline $37-1,130.5$ & 1248.81 & 2.72 (out of liner) & & $4 c$ & VA & Clayey limestone \\
\hline $37-1,130.5$ & 1248.81 & $2.19^{\mathrm{a}}$ (out of liner) & & $4 \mathrm{c}$ & VA & Clayey limestone \\
\hline $37-2,137.0$ & 1250.37 & 2.97 (out of liner) & & $4 \mathrm{c}$ & VA & Clayey limestone \\
\hline $37-2,137.0$ & 1250.37 & $2.55^{\mathrm{a}}$ (out of liner) & 5.99 & $4 \mathrm{c}$ & VA & Clayey limestone \\
\hline $38-1,99.0$ & 1257.99 & 3.54 (out of liner) & & $4 d$ & VB & Clayey limestone \\
\hline $38-1,99.0$ & 1257.99 & $3.23^{\mathrm{a}}$ (out of liner) & & $4 d$ & VB & Clayey limestone \\
\hline $38-2,129.0$ & 1259.79 & 3.29 (out of liner) & & $4 d$ & VB & Clayey limestone \\
\hline $38-2,129.0$ & 1259.79 & $3.15^{\mathrm{a}}$ (out of liner) & 7.50 & $4 d$ & VB & Clayey limestone \\
\hline $38-3,101.0$ & 1261.01 & 3.49 (out of liner) & & $4 d$ & VB & Clayey limestone \\
\hline $38-3,101.0$ & 1261.01 & $3.23^{\mathrm{a}}$ (out of liner) & & $4 d$ & VB & Clayey limestone \\
\hline $38-4,80.0$ & 1262.30 & $3.67^{\mathrm{a}}$ (out of liner) & 8.88 & $4 d$ & VB & Clayey limestone \\
\hline $38-4,80.0$ & 1262.30 & 3.39 (out of liner) & & $4 d$ & VB & Clayey limestone \\
\hline
\end{tabular}


TABLE 8 - Continued

\begin{tabular}{|c|c|c|c|c|c|c|}
\hline $\begin{array}{c}\text { Sample } \\
\text { (Interval in (m)) }\end{array}$ & $\begin{array}{l}\text { Depth in } \\
\text { Hole }(m)\end{array}$ & $\begin{array}{l}\text { Velocity } \\
(\mathrm{km} / \mathrm{sec})\end{array}$ & $\begin{array}{c}\text { Impedance } \\
\left(\mathrm{g} / \mathrm{cm}^{2} \sec \times 10^{5}\right)\end{array}$ & $\begin{array}{c}\text { Lithologic } \\
\text { Unit }\end{array}$ & $\begin{array}{l}\text { Acoustic } \\
\text { Unit }\end{array}$ & Lithology \\
\hline $39-2,35.0$ & 1268.35 & $3.22^{\mathrm{a}}$ (out of liner) & 7.73 & $4 d$ & VB & Clayey limestone \\
\hline $39-2,35.0$ & 1268.35 & 3.49 (out of liner) & & $4 \mathrm{~d}$ & VB & Clayey limestone \\
\hline $39-2,135.0$ & 1269.35 & $3.77^{\mathrm{a}}$ (out of liner) & & $4 d$ & VB & Limestone \\
\hline $39-2,135.0$ & 1269.35 & 3.91 (out of liner) & & $4 d$ & VB & Limestone \\
\hline $39-4,102.0$ & 1272.02 & $2.95^{\mathrm{a}}$ (out of liner) & 7.14 & $4 d$ & VB & Claystone \\
\hline $39-4,102.0$ & 1272.02 & 3.22 (out of liner) & & $4 d$ & VB & Claystone \\
\hline $39-5,73.0$ & 1273.23 & $3.55^{\mathrm{a}}$ (out of liner) & & $4 d$ & VB & Limestone \\
\hline $39-5,73.0$ & 1273.23 & 3.84 (out of liner) & & $4 \mathrm{~d}$ & VB & Limestone \\
\hline $40-2,48.0$ & 1277.98 & $3.98^{\mathrm{a}}$ (out of liner) & 7.68 & $4 d$ & VB & Limestone \\
\hline $40-2,48.0$ & 1277.98 & 3.97 (out of liner) & & $4 d$ & VB & Limestone \\
\hline $40-3,110.0$ & 1280.10 & $3.00^{\mathrm{a}}$ (out of liner) & & $4 d$ & VB & Limestone \\
\hline $40-3,110.0$ & 1280.10 & 3.23 (out of liner) & & $4 d$ & VB & Limestone \\
\hline $40-4,29.0$ & 1280.79 & $3.45^{\mathrm{a}}$ (out of liner) & 12.83 & $4 d$ & VB & Limestone \\
\hline $40-4,29.0$ & 1280.79 & 3.61 (out of liner) & & $4 d$ & VB & Limestone \\
\hline $40-5,33.0$ & 1282.33 & $3.37^{\mathrm{a}}$ (out of liner) & & $4 \mathrm{~d}$ & VB & Limestone \\
\hline $40-5,33.0$ & 1282.33 & 3.71 (out of liner) & & $4 d$ & VB & Limestone \\
\hline $41-1,24.0$ & 1285.74 & $3.12^{\mathrm{a}}$ (out of liner) & 7.30 & $4 d$ & VB & Limestone \\
\hline $41-1,24.0$ & 1285.74 & 3.23 (out of liner) & & $4 d$ & VB & Limestone \\
\hline $41-2,26.0$ & 1287.26 & $3.11^{\mathrm{a}}$ (out of liner) & & $4 d$ & VB & Limestone \\
\hline $41-2,26.0$ & 1287.26 & 3.35 (out of liner) & & $4 d$ & VB & Limestone \\
\hline $41-3,76.0$ & 1289.26 & $2.93^{\mathrm{a}}$ (out of liner) & & $4 d$ & VB & Limestone \\
\hline $41-3,76.0$ & 1289.26 & 3.12 (out of liner) & & $4 d$ & VB & Limestone \\
\hline $41-4,127: 0$ & 1291.27 & $3.53^{\mathrm{a}}$ (out of liner) & 8.51 & $4 d$ & VB & Limestone \\
\hline $41-4,127.0$ & 1291.27 & 3.63 (out of liner) & & $4 \mathrm{~d}$ & VB & Limestone \\
\hline $42-1,101.0$ & 1296.01 & $3.11^{\mathrm{a}}$ (out of liner) & & $4 d$ & VB & Limestone \\
\hline $42-1,101.0$ & 1296.01 & 3.23 (out of liner) & & $4 d$ & VB & Limestone \\
\hline $42-2,106.0$ & 1297.56 & 3.35 (out of liner) & & $4 d$ & VB & Limestone \\
\hline $42-2,106.0$ & 1297.56 & $3.27^{\mathrm{a}}$ (out of liner) & 7.72 & $4 d$ & VB & Limestone \\
\hline $42-3,127.0$ & 1299.27 & 3.37 (out of liner) & & $4 d$ & VB & Limestone \\
\hline $42-3,127.0$ & 1299.27 & $3.24^{\mathrm{a}}$ (out of liner) & & $4 d$ & VB & Limestone \\
\hline $42-4,60.0$ & 1300.10 & $3.79^{\mathrm{a}}$ (out of liner) & 9.40 & $4 d$ & VB & Limestone \\
\hline $42-4,60.0$ & 1300.10 & 3.81 (out of liner) & & $4 d$ & VB & Limestone \\
\hline $42-5,20.0$ & 1301.20 & $3.28^{\mathrm{a}}$ (out of liner) & & $4 d$ & VB & Claystone \\
\hline $42-5,20.0$ & 1301.20 & 3.42 (out of liner) & & $4 d$ & VB & Claystone \\
\hline $43-1,92.0$ & 1305.42 & $2.99^{a}$ (out of liner) & 7.23 & $4 d$ & VB & Claystone \\
\hline $43-1,92.0$ & 1305.42 & 3.34 (out of liner) & & $4 d$ & VB & Claystone \\
\hline $43-2,70.0$ & 1306.70 & $3.29^{\mathrm{a}}$ (out of liner) & & $4 d$ & VB & Limestone \\
\hline $43-2,70.0$ & 1306.70 & 3.51 (out of liner) & & $4 d$ & VB & Limestone \\
\hline $43-3,36.0$ & 1307.86 & $3.31^{\mathrm{a}}$ (out of liner) & 7.91 & $4 d$ & VB & Limestone \\
\hline $43-3,36.0$ & 1307.86 & 3.45 (out of liner) & & $4 d$ & VB & Limestone \\
\hline $43-4,124.0$ & 1310.24 & $3.38^{\mathrm{a}}$ (out of liner) & & $4 d$ & VB & Limestone \\
\hline $43-4,124.0$ & 1310.24 & 3.45 (out of liner) & & $4 d$ & VB & Limestone \\
\hline $44-2,136.0$ & 1316.86 & $3.54^{\mathrm{a}}$ (out of liner) & 8.67 & $4 d$ & VB & Limestone \\
\hline $44-2,136.0$ & 1316.86 & 3.77 (out of liner) & & $4 d$ & VB & Limestone \\
\hline $44-3,135.0$ & 1318.35 & $3.53^{\mathrm{a}}$ (out of liner) & & $4 d$ & VB & Limestone \\
\hline $44-3,135.0$ & 1318.35 & 3.78 (out of liner) & & $4 d$ & VB & Limestone \\
\hline $44-4,133.0$ & 1319.83 & $3.47^{\mathrm{a}}$ (out of liner) & 8.57 & $4 d$ & VB & Limestone \\
\hline $44-4,133.0$ & 1319.83 & 3.56 (out of liner) & & $4 d$ & VB & Limestone \\
\hline $44-5,116.0$ & 1321.16 & $3.62^{\mathrm{a}}$ (out of liner) & & $4 d$ & VB & Limestone \\
\hline $44-5,116.0$ & 1321.16 & 3.75 (out of liner) & & $4 d$ & VB & Limestone \\
\hline $44-6,120.0$ & 1322.70 & $3.25^{\mathrm{a}}$ (out of liner) & 7.90 & $4 d$ & VB & Limestone \\
\hline $44-6,120.0$ & 1322.70 & 3.50 (out of liner) & & $4 d$ & VB & Limestone \\
\hline $45-1,59.0$ & 1324.09 & $3.62^{\mathrm{a}}$ (out of liner) & 8.91 & $5 \mathrm{a}$ & VI & Limestone \\
\hline $45-1,59.0$ & 1324.09 & 3.83 (out of liner) & & 5 a & VI & Limestone \\
\hline $45-2,32.0$ & 1325.32 & 3.67 (out of liner) & & $5 \mathrm{a}$ & VI & Limestone \\
\hline $45-2,32.0$ & 1325.32 & $3.45^{\mathrm{a}}$ (out of liner) & 8.45 & $5 \mathrm{a}$ & VI & Limestone \\
\hline $45-3,67.0$ & 1327.17 & $3.76^{\mathrm{a}}$ (out of liner) & 9.32 & $5 a$ & VI & Limestone \\
\hline $45-3,67.0$ & 1327.17 & 3.90 (out of liner) & & $5 \mathrm{a}$ & VI & Limestone \\
\hline $46-1,63.0$ & 1333.63 & $2.69^{\mathrm{a}}$ (out of liner) & & $5 \mathrm{a}$ & VI & Limestone \\
\hline $46-1,63.0$ & 1333.63 & 3.11 (out of liner) & & $5 \mathrm{a}$ & VI & Limestone \\
\hline $46-1,65.0$ & 1333.65 & $2.50^{\mathrm{a}}$ (out of liner) & & $5 \mathrm{a}$ & VI & Limestone \\
\hline $46-1,65.0$ & 1333.65 & 2.95 (out of liner) & & $5 a$ & VI & Limestone \\
\hline $47-1,55.0$ & 1343.05 & 3.24 (out of liner) & & $5 \mathrm{a}$ & VI & Limestone \\
\hline $47-1,55.0$ & 1343.05 & $2.93^{\mathrm{a}}$ (out of liner) & 6.21 & $5 \mathrm{a}$ & VI & Calcareous claystone \\
\hline $48-2,144.0$ & 1354.94 & 4.57 (out of liner) & & $5 \mathrm{a}$ & VI & Calcareous claystone \\
\hline $48-2,144.0$ & 1354.94 & $4.80^{\mathrm{a}}$ (out of liner) & & $5 \mathrm{a}$ & VI & Limestone \\
\hline $49-2,16.0$ & 1363.16 & 5.11 (out of liner) & & $5 \mathrm{a}$ & VI & Limestone \\
\hline $49-2,16.0$ & 1363.16 & $5.12^{\mathrm{a}}$ (out of liner) & 13.57 & $5 \mathrm{a}$ & VI & Limestone \\
\hline
\end{tabular}


TABLE 8 - Continued

\begin{tabular}{|c|c|c|c|c|c|c|}
\hline $\begin{array}{c}\text { Sample } \\
\text { (Interval in (m)) }\end{array}$ & $\begin{array}{l}\text { Depth in } \\
\text { Hole }(\mathrm{m})\end{array}$ & $\begin{array}{l}\text { Velocity } \\
(\mathrm{km} / \mathrm{sec})\end{array}$ & $\begin{array}{c}\text { Impedance } \\
\left(\mathrm{g} / \mathrm{cm}^{2} \sec \times 10^{5}\right)\end{array}$ & $\begin{array}{c}\text { Lithologic } \\
\text { Unit }\end{array}$ & $\begin{array}{l}\text { Acoustic } \\
\text { Unit }\end{array}$ & Lithology \\
\hline $49-2,89.0$ & 1363.89 & 2.38 (out of liner) & & $5 \mathrm{a}$ & VI & Calcareous claystone \\
\hline $49-2,89.0$ & 1363.89 & $2.75^{\mathrm{a}}$ (out of liner) & 6.46 & $5 \mathrm{a}$ & VI & Calcareous claystone \\
\hline $50-1,84.0$ & 1371.84 & $3.10^{\mathrm{a}}$ (out of liner) & 7.59 & $5 b$ & VI & Calcareous claystone \\
\hline $50-1,84.0$ & 1371.84 & 3.50 (out of liner) & & $5 b$ & VI & Calcareous claystone \\
\hline $51-2,84.0$ & 1382.84 & 2.69a (out of liner) & 5.59 & $5 b$ & VI & Calcareous claystone \\
\hline $51-2,84.0$ & 1382.84 & 3.20 (out of liner) & & $5 b$ & VI & Calcareous claystone \\
\hline $52-2,93.0$ & 1392.43 & $2.32^{\mathrm{a}}$ (out of liner) & & $5 \mathrm{~b}$ & VI & Calcareous claystone \\
\hline $52-2,93.0$ & 1392.43 & 2.63 (out of liner) & & $5 b$ & VI & Calcareous claystone \\
\hline $52-3,72.0$ & 1393.72 & $2.71^{\mathrm{a}}$ (out of liner) & & $5 b$ & VI & Calcareous claystone \\
\hline $52-3,72.0$ & 1393.72 & 3.16 (out of liner) & & $5 b$ & VI & Calcareous claystone \\
\hline $52-4,85.0$ & 1395.35 & $2.69^{\mathrm{a}}$ (out of liner) & 6.56 & $5 \mathrm{~b}$ & VI & Calcareous claystone \\
\hline $52-4,85.0$ & 1395.35 & 3.11 (out of liner) & & $5 \mathrm{~b}$ & VI & Calcareous claystone \\
\hline
\end{tabular}

${ }^{\mathrm{a}}$ Velocity measured perpendicular to bedding (all others measured parallel to bedding).

The lowermost lithologic unit 5 ( = acoustic unit VI) is variegated limestones and dark red calcareous claystones. A well-defined break occurs between this and overlying unit VB; the acoustic Unit VI sediments have a lower average velocity of $3.22 \mathrm{~km} / \mathrm{sec}$ perpendicular to bedding.

Velocity and impedance data generally support the seismic/lithologic correlation except perhaps at the 0.32-sec reflector where we noted no significant change, and spanning horizon $A$ where we do not have sufficient data points.

\section{Water Content, Porosity, and Wet Bulk Density}

Water content, porosity, and wet bulk density were measured on small $(<1 \mathrm{cc})$ "water content" samples by the "syringe" technique (soft sediments) or "chunk" technique (hard sediments). The volume of sediment is measured directly from the $\mathrm{ml}$ syringe sampler in the syringe technique. Volume of hard sediment is determined by difference in weights between air and water (Jolly-type balance) in the chunk technique. A sample which is incompletely indurated may disaggregate when submerged in water and/or absorb rather than displace water. Consequently, chunk volume determinations and resulting porosity and density determinations can be somewhat less reliable than the syringe technique. Density determinations below Core 4 (Hole 391A) and Core 6 (391C) were made with chunk samples weighed on the Jolly-type balance. Most of the Hole 391C samples, however, were sufficiently hard to provide reliable data.

Water content is expressed at wet weight of the sample.

$$
\text { Water content }=\frac{\text { wt. evaporated water }}{\text { wt. wet sediment }} \times 100
$$

Porosity was determined by measuring weight of evaporated water (assuming that pore space was filled with water) and volume.

$$
\% \text { porosity }=\frac{\text { wt. water }}{\text { volume wet sediment }}
$$

Wet bulk density (wt. wet sediment/vol. wet sediment) was determined by syringe and chunk methods.
Water content, wet bulk density, and porosity were determined on 32 samples from Hole $391 \mathrm{~A}$ and 98 samples from Hole 391C; data are presented in Table 10.

Average water contents, wet bulk densitys and porosity for each lithologic unit are shown in Tables 11, 12, and 13, respectively.

\section{GRAPE}

Measurements of wet bulk density and porosity were taken on samples of known dimensions with the Gamma Ray Attenuation Porosity Evaluator (GRAPE). Sediments from Holes 391A and 391C were hard and could be removed from the liners allowing special two-minute counts to be made on selected samples diminishing the variation encountered by continuous scan. GRAPE data were collected on 10 sections Hole $391 \mathrm{~A}$ and 100 sections Hole 391C. These data are presented with the visual core descriptions and core photos at the end of this chapter.

\section{BIOSTRATIGRAPHY}

\section{Summary}

Four holes at Site 391 were drilled in the Blake-Bahama Basin at a water depth of 4874 meters. A combination of Holes $391 \mathrm{~A}$ and $391 \mathrm{C}$ gives a fairly complete stratigraphic record to a sub-bottom depth of 1412 meters. Five lithologic units are recognized; the first two units were extensively sampled from Hole 391A (Quaternary, Miocene), and the three deeper units were sampled from Hole 391C (Lower Cretaceous-uppermost Jurassic).

The uppermost 20 cores of Hole 391A contain Quaternary and Miocene sediments. The sedimentary sequence consists of silty clays, intraclastic chalk, carbonate turbidites, and hemipelagic and pelagic mudstones. Nearly all of the carbonate sediments at this site are allochthonous and thus age determinations within the units are made on the basis of the youngest age of any microfossil group - unless down-hole contamination was obvious. The sequence cored at Hole 391A yielded abundant nannofossils, foraminifers, and radiolarians at different intervals. The carbonate sediments were dated primarily on the basis of foraminifers and nannofossils; the mudstones, upon radiolarians and nannofossils. A summary 
TABLE 9

Average Velocity and Impedance for Each Acoustic Unit

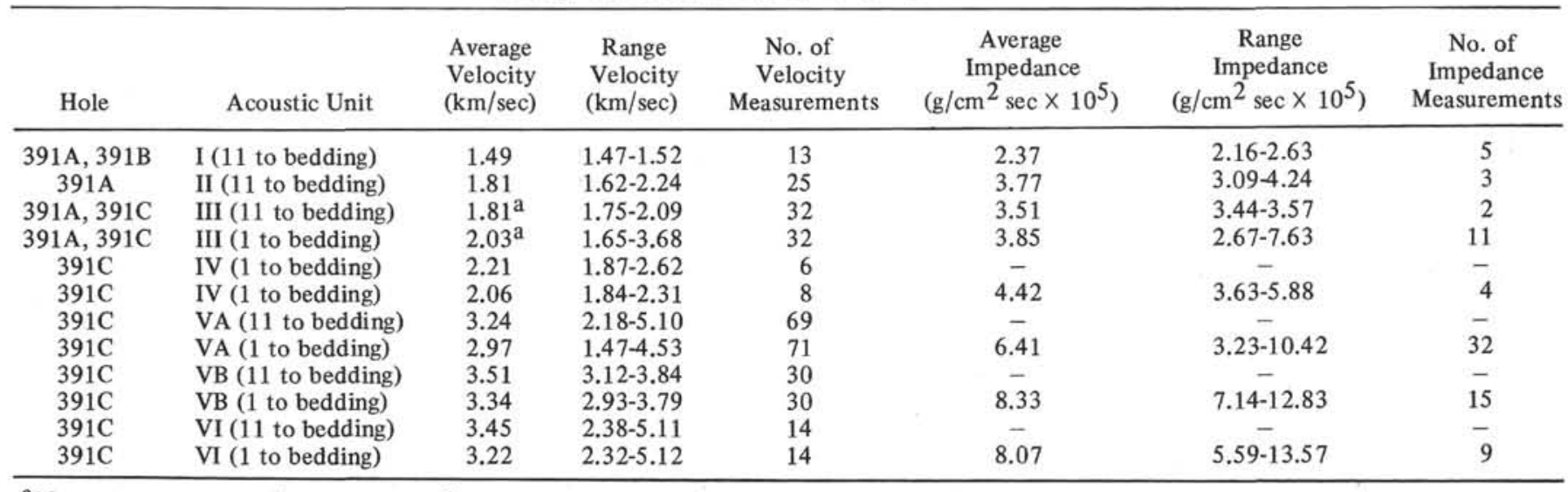

${ }^{\mathrm{a}}$ Measurements not made on same sample.

of the preliminary paleontological results is presented in Figure 20.

\section{Quaternary}

Quaternary sediments were recovered from Hole 391A Core 1 to Core 3, Section 1 (lithological unit 1). Calcareous nannofossils and foraminifers are abundant and moderately well preserved throughout this interval. These Cores fall within the $G$. truncatulinoides and $G$. calida foraminifer zones (N.22 and N.23), and within the P. lacunosa and $G$. oceanica/E. huxleyi nannofossil zones (NN 19 and NN 21). Radiolarians occur in Sample 2, CC and the assemblage is diagnostic of the Quaternary Lamprocyrtis haysi Zone of Riedel and Sanfilippo (1974). All the Quaternary sediments contain some reworked older species (see also below).

\section{Upper Miocene}

Lithologic sub-unit 2a (Core 3, Section 2 to Core 4, Section 2) consists of calcareous ooze, chalk, and marly chalk. Abundant but poorly preserved nannofossils occur throughout the interval. Most of the discoasters are heavily overgrown, but some specimens of $D$. quinqueramus are recognizable and the unit is assigned to the $D$. quinqueramus Zone (NN 11). A diverse assemblage of planktonic foraminifers also occurs within this interval; it is assigned to the $G$. plesiotumida Zone (N.17). Only Core 4, Section 1 contains radiolarians. The assemblage is middle Miocene and is probably reworked/worked from older sedimentary sequences. All of the Pliocene missing which suggests that an unconformity exists in Core 3 (Figure 20).

\section{Middle Miocene}

Middle Miocene sediments recovered in Hole 391A, Core 4, Section 2 through Core 12 at Hole 391A are composed of intraclastic chalk, chalk, and mudstone. Except for the mudstone units in Core 4, Section 4, Core 7, and the upper portion of Core 8 , the middle Miocene sequence consists of displaced sediments. Mudstone clasts within the intraclastic chalks in most cases appear to be basinal sediments that were eroded and redeposited within the carbonate sediments. As expected, these sediments contain many reworked fossils. Consequently, we dated these cores by the age of the youngest fossil group present, regardless of discrepancies in interzonal correlations between nannofossils, foraminifers, and radiolarians.

The mudstone clasts of the intraclastic chalks are rich in radiolarians and some also contain nannofossils. Numerous intraclasts, especially in Hole 391A Cores 4 through 11, were sampled to determine whether these sediments are the same age as the chalks, and to establish if they are in proper stratigraphic order. Generally the clasts are from the same nannofossil zone as the chalk matrix (NN 5). An exception is in Core 391A-8 in which a bluish mudstone layer and a clast of the same color are older (NN 2). Thus an older mudstone (as clasts of various size) is entrapped in sediments of younger age.

The interval from Hole 391A Core 4, CC to Core 6, Section 3, contains abundant and well preserved foraminifers diagnostic of the Sph. subdehiscens Zone (N.13). Core 6, Section 4 contains abundant foraminifers with components of both the G. fohsi and Sph. subdehiscens zones present (N.12 and N.13). The nannofossils within this interval are too poorly preserved to give a reliable age. Radiolarians, however, are diagnostic of the Dorcadospyris alata Zone (middle Miocene), which is in agreement with the foraminifer data.

Core 7 and 8 are dominantly siliceous mudstone and all three microfossil groups are present to some extent. Nannofossils characteristic of the $S$. hetermorphus (NN 5) Zone, foraminifers representative of the $G$. peripheroronda and $G$. peripheroacuta zones (N.9 to N.10), and radiolarians of the Dorcadospyris alata Zone are present (Figure 20). Core 8, Section 1 below $135 \mathrm{~cm}$ and Sample 8, $\mathrm{CC}$ yielded nannofossils and radiolarians diagnostic of earliest Miocene sediments (NN 2 and the Cyrotocapsella tetrapera Zone). These sediments, which could be clasts, are obviously allochthonous within the middle Miocene sediments recovered at this hole.

Hole 391A, Cores 9 through 11 consist of intraclastic chalk and are assigned to the $G$. peripheroronda to $G$. sicanus foraminifer zones (N.8 to N.9). Calcareous nannofossils characteristic of the $S$. heteromorphus Zone (NN 5) are still present within these cores. Radiolarians are abundant and well preserved throughout Cores 9 through 12 , and are tentatively assigned to the Calocycletta costata Zone. This zone is somewhat older than those indicated by 
the foraminifer and nannofossil data which suggests the older radiolarians were reworked into younger sediments via the mudstone clasts.

Eocene and Cretaceous microfossils are reworked throughout the Miocene section recovered at Hole 391A. In many cases these reworked specimens are so numerous that they dominate the younger forms (see below).

\section{Lower Miocene}

We recovered lower Miocene sediments in Cores 12 through 20 in Hole 391A. Nannofossils and radiolarians are abundant and well preserved throughout the interval, but foraminifers are numerous only in Cores 18 and 19. Core 12 , CC through Core 20 are characterized by the sequential progression of nannofossil zones from the $H$. ampliaperta (NN 4) down through the Triquetrorhabdulus carinatus zones (NN 1). Core 13 falls within the Calocycletta costata radiolarian zone and Core 16 is assigned to the Stichocorys delmontense Zone of Riedel and Sanfilippo (1974). Cores 17-19 belong to the $C$. tetrapera Zone and Core 20 is assigned to the L. elongata Zone. The lower Miocene $G$. kugleri (N.4) foraminifer zone is recognized in Cores 18 and 19.

Core 21 is black shale, similar to that identified as mid-Cretaceous in other parts of the North and South Atlantic basins. The unit is unfossiliferous at Hole 391A and if the lithostratigraphic comparison is correct a major unconformity exists between Cores 20 and 21 where lower Miocene sediments rest on Mid-Cretaceous shale. This apparent unconformity correlates with reflecting horizon $A$ in the Blake-Bahama Basin.

\section{Cretaceous-Upper Jurassic}

In Hole 391C we sampled the section below that cored in Hole 391A. We took three "spot" cores in the interval covered by $391 \mathrm{~A}$, then began drilling Hole $391 \mathrm{C}$ in earnest in the dark claystone at a depth of 658.5 meters. Cores 4 to 54 sampled Cretaceous-Upper Jurassic sediments to a sub-bottom depth of 1412 meters. The three lithologic units cored are unit 3, noncalcareous and calcareous claystone (Upper Cretaceous?-Aptian); unit 4, white calcilutite and shaley intercalations of varying character (upper Tithonian-Barremain); and unit 5, variegated calcilutite and red marlstone (lower Tithonian).

Nannofossils are generally common and well preserved in Cores 1 to 54 . We found few foraminifers, both in numbers of species and specimens, in Cores 4 to 54. Preservation is much worse than at Sites 390 and 392, and most of the sediment at Site 391 seems to lack tests.

Below Core 11 pyritized and calcified spheres are common and are probably replaced radiolarians. Ammonite aptychi are present in most of the Cretaceous and Upper Jurassic cores.

In Cores 5 to 8 , an arenaceous foraminifer fauna, the Plectorecurvoides assemblage, indicates general Albian to Upper Cretaceous (?) sediments.

Core 11 contains a meager upper Aptian-lower Albian fauna of planktonic foraminifers. Core 14 correlates to the lower part of the upper Barremian Hedbergella sigali Zone (LC8 pp).

Foraminifers in Cores 24 to 26 indicate Valanginian sediments. Cores 50 to 52 correlate to the Epistomina mosquensis Zone in the Grand Banks of Newfoundland, thought to be of Oxfordian to Kimmeridgian age, and to Oxfordian to Kimmeridgian/Tithonian beds in DSDP Leg 11 , Sites 100 and 105.

A succession of calcareous nannofossil zone shows that the interval from Cores 9 to 54 (929.5-1412 m) contains lower Albian-lower Tithonian sediments. Most of the zonal sequences of Thierstein $(1971,1973)$ for the Lower Cretaceous and of Barnard and Hay (1974) for the Jurassic are recognized in this interval Figure 21.

\section{Depositional Environment}

Most of the sediments between Cores 3 and 20 at Hole $391 \mathrm{~A}$ are composed of deep water pelagic foraminifers, nannoplankton, and radiolarians. At various intervals the sequence also contains appreciable amounts of reworked Miocene, Eocene, and Cretaceous planktonic microfossils. Cores $3,5,6,11$, and 18 contain Miocene (?) benthic foraminifers, and Core 12 contains Eocene larger foraminifers which indicate shallow-water depositional environments. Further evidence of shallow-water sediments within the carbonate sequence is the abundance of uniaxial (monaxon) sponge spicules throughout this sequence. Uniaxial sponge spicules are restricted to the monactinellid sponges. They occur from the littoral zone down to abyssal depths, but are only abundant down to several hundred meters.

Paleontological evidence therefore suggests that carbonate at Hole 391A was displaced from both shallow and deeper marine source areas. The Bahama channels, e.g. the NE and NW Providence Channels and possibly the Tongue of the Ocean may have provided shallow-marine Eocene and Miocene debris (see also Foraminifers, this chapter). Deeper marine sediments were redeposited from the adjacent Blake Plateau. The largest volume of sediment probably was derived from the latter region.

Because of the scarcity of foraminifers and ostracodes and the relative abundance of nannofossils in the Tithonian to lower Albian sediments (Hole 391C), we conclude that the sea floor near Site 391 during that time was between the CCD for foraminifers and nannofossils. At present this depth is between 4.5 and $5.5 \mathrm{~km}$.

The equation of sea-floor depth as a function of age of the ocean crust (Le Pichon et al., 1973, fig. 18) shows that the Tithonian water depth was about $4 \mathrm{~km}$ and the Albian depth was about $4.5 \mathrm{~km}$. The "'backtracking"' method works best for relatively young crust and exceptions do occur to this empirical relationship, consequently, these figures should be treated with caution.

The Albian-Upper Cretaceous(?) dark shale, characterized by an "impoverished" arenaceous fauna and lack of nannofossils, was probably deposited below the $\mathrm{CCD}$, for all calcareous fossils at a depth close to the present one.

\section{Foraminifers}

\section{Hole 391A}

The upper 20 cores of Hole 391A contain Quaternary and Miocene foraminifer assemblages. No Pliocene faunas were found. The Quaternary, penetrated by Cores 1 through 3-1, corresponds to lithologic unit 1 . It is approximately 155 


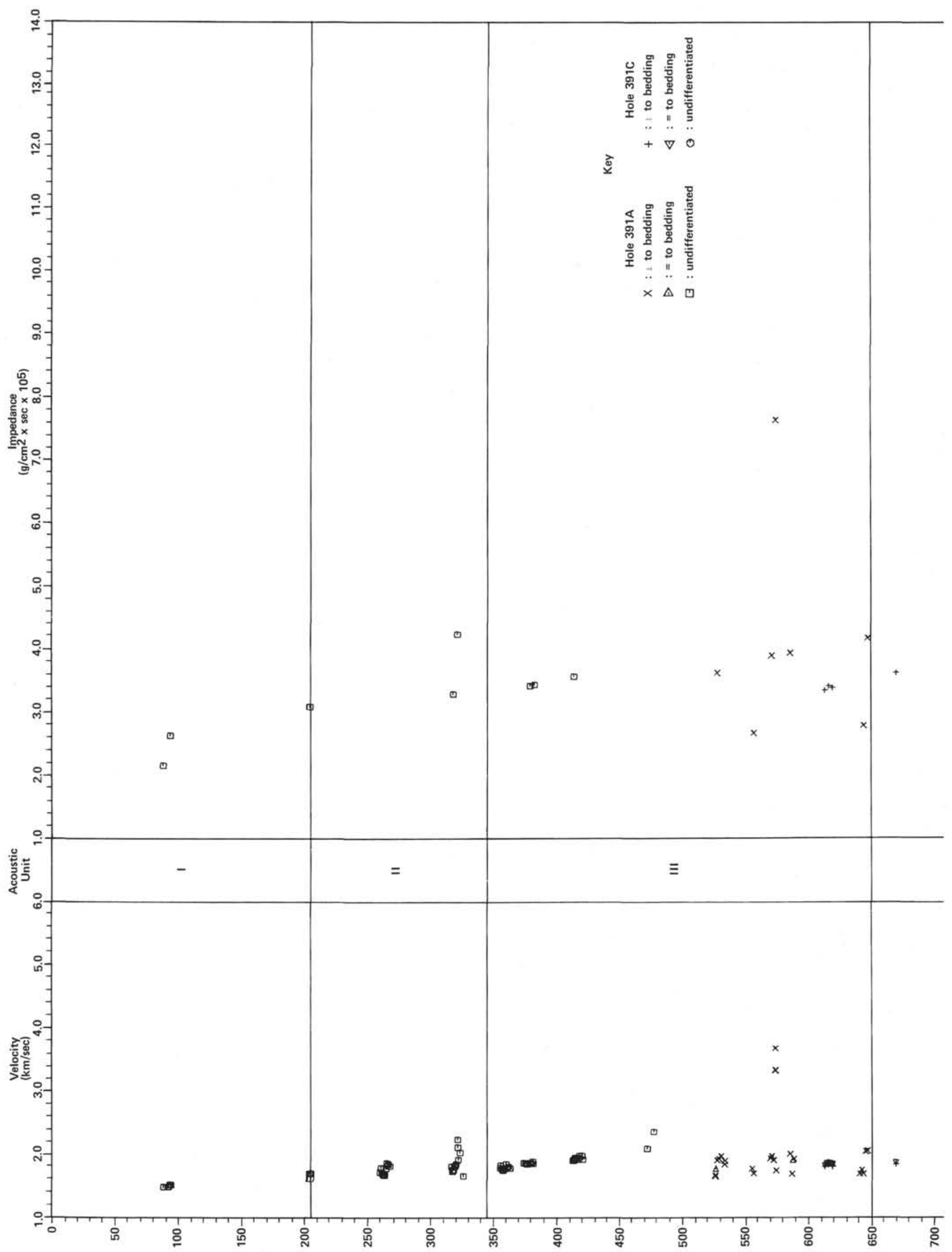

Figure 19. Impedance and velocity versus depth, Site 391. 


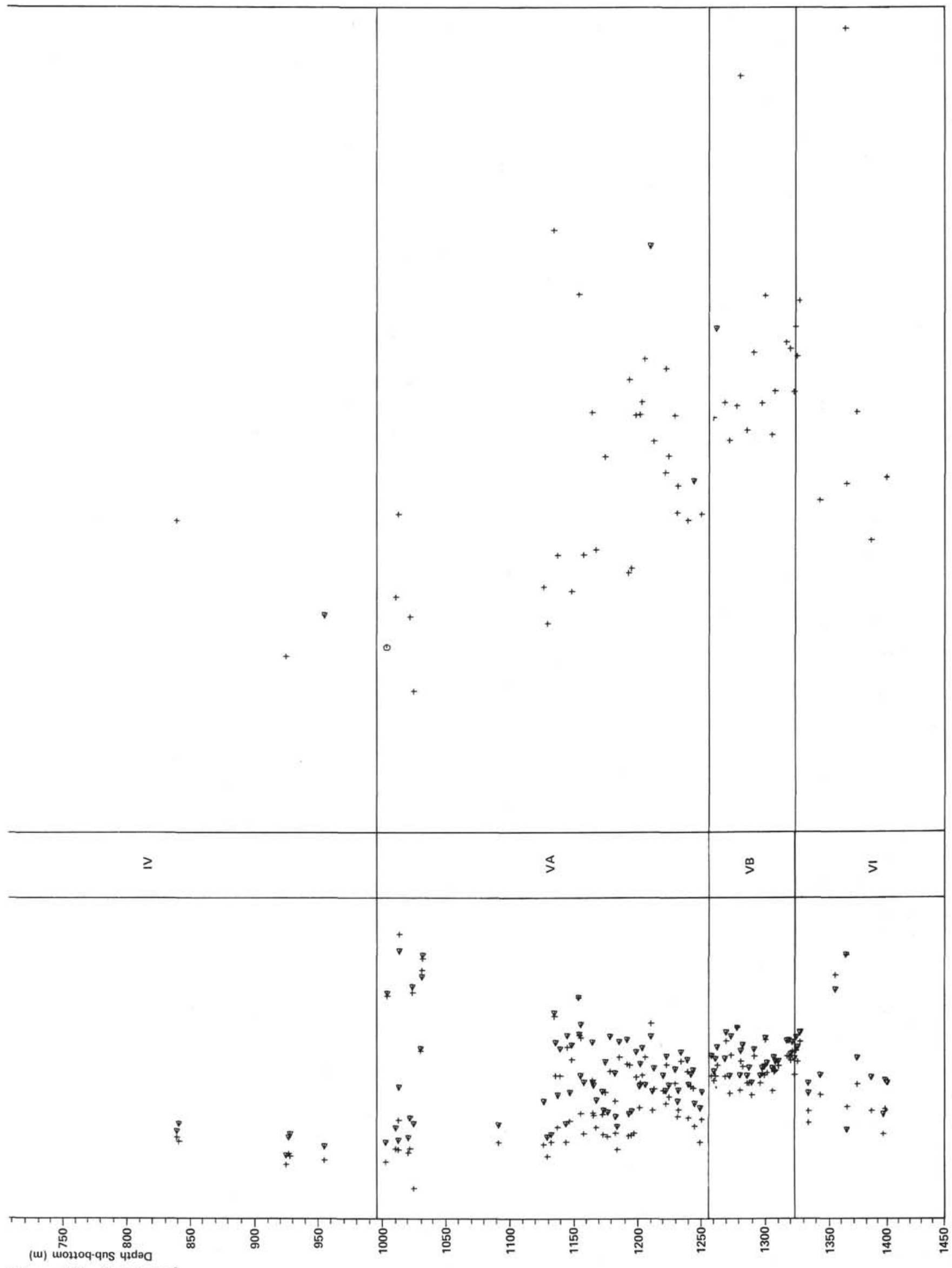

Figure 19. Continued. 
TABLE 10

Water Content, Porosity, and Wet Bulk Density, Part 1 Site 391

\begin{tabular}{|c|c|c|c|c|c|c|}
\hline $\begin{array}{c}\text { Sample } \\
\text { (Interval in } \mathrm{cm} \text { ) }\end{array}$ & $\begin{array}{l}\text { Depth in } \\
\text { Hole }(m)\end{array}$ & $\begin{array}{c}\text { Water Content } \\
(\%)\end{array}$ & $\begin{array}{l}\text { Wet Bulk Density } \\
(\mathrm{g} / \mathrm{cc})\end{array}$ & $\begin{array}{l}\text { Porosity } \\
(\%)\end{array}$ & $\begin{array}{l}\text { Lithologic } \\
\text { Unit }\end{array}$ & Lithology \\
\hline \multicolumn{7}{|l|}{ Hole 391A } \\
\hline $1-2,107.5$ & 88.58 & 24.4 & 1.44 & 35.1 & 1 & Silty clay \\
\hline $1-6,77.5$ & 94.28 & 28.2 & 1.73 & 48.7 & 1 & Silty clay \\
\hline Core 2 averages & & 26.3 & 1.58 & 41.9 & & \\
\hline $3-3,60.5$ & 149.11 & 30.0 & 1.79 & 53.7 & $2 \mathrm{a}$ & Calcareous ooze \\
\hline $3-5,59.5$ & 152.10 & 24.7 & 1.94 & 48.0 & $2 \mathrm{a}$ & Calcareous ooze \\
\hline Core 3 averages & & 27.3 & 1.87 & 50.9 & & \\
\hline $4-2,92.5$ & 204.93 & 25.3 & 1.91 & 48.3 & $2 \mathrm{a}$ & Marly chalk \\
\hline $4-4,81.5$ & 207.82 & 26.7 & 1.91 & 50.9 & $2 b$ & Intraclastic marly chalk \\
\hline Core 4 averages & & 26.0 & 1.92 & 49.6 & & \\
\hline $5-2,81.0$ & 262.21 & 30.3 & 1.80 & 54.4 & $2 \mathrm{~b}$ & Intraclastic marly chalk \\
\hline $5-4,74.5$ & 265.15 & 31.1 & 1.77 & 55.2 & $2 b$ & Intraclastic marly chalk \\
\hline $5-6,83.5$ & 268.24 & 27.9 & 1.84 & 51.4 & $2 b$ & Intraclastic marly chalk \\
\hline Core 5 averages & & 29.7 & 1.81 & 53.7 & & \\
\hline $6-2,37.5$ & 318.38 & 25.3 & 1.89 & 47.6 & $2 b$ & Intraclastic chalk \\
\hline $6-4,75.5$ & 321.76 & 20.5 & 2.00 & 41.7 & $2 b$ & Intraclastic marly chalk \\
\hline Core 6 averages & & 22.9 & 1.94 & 44.3 & & \\
\hline $7-1,81.5$ & 326.82 & 42.3 & 1.53 & 64.7 & $2 \mathrm{c}$ & Radiolarian mudstone \\
\hline $7-4,34.5$ & 330.85 & 41.2 & 1.55 & 63.9 & $2 \mathrm{c}$ & Radiolarian mudstone \\
\hline $7-5,37.5$ & 332.38 & 43.6 & 1.47 & 64.0 & $2 c$ & Radiolarian mudstone \\
\hline Core 7 averages & & 42.4 & 1.52 & 64.2 & & \\
\hline $8-1,90.5$ & 336.41 & 45.5 & 1.48 & 67.3 & $2 \mathrm{c}$ & Radiolarian mudstone \\
\hline $9-2,76.5$ & 357.27 & 27.3 & 1.81 & 49.4 & $2 d$ & Intraclastic marly chalk \\
\hline $9-6,65.6$ & 363.16 & 27.5 & 1.81 & 49.7 & $2 \mathrm{~d}$ & Intraclastic marly chalk \\
\hline Core 9 averages & & 27.4 & 1.81 & 49.5 & & \\
\hline $10-2,71.0$ & 376.11 & 26.5 & 1.84 & 48.8 & $2 d$ & Intraclastic marly chalk \\
\hline $10-4,69.0$ & 379.09 & 26.8 & 1.83 & 49.0 & $2 \mathrm{~d}$ & Intraclastic marly chalk \\
\hline $10-6,13.0$ & 381.53 & 26.1 & 1.85 & 48.3 & $2 d$ & Intraclastic marly chalk \\
\hline Core 10 averages & & 26.4 & 1.84 & 48.7 & & \\
\hline $11-2,85.0$ & 414.35 & 26.2 & 1.84 & 48.3 & $2 \mathrm{~d}$ & Intraclastic chalk \\
\hline $12-4,109.0$ & 474.59 & 22.4 & 1.93 & 43.3 & $2 \mathrm{~d}$ & Intraclastic chalk \\
\hline $13-2,7.0$ & 527.57 & 23.5 & 1.90 & 44.7 & $2 \mathrm{e}$ & Nannofossil chalk \\
\hline $16-2,95.0$ & 556.45 & 40.4 & 1.57 & 63.3 & $2 \mathrm{e}$ & Siliceous mudstone \\
\hline $17-2,74.0$ & 570.74 & 20.6 & 1.97 & 40.7 & $2 \mathrm{e}$ & Nannofossil chalk \\
\hline $17-4,78.0$ & 573.78 & 9.7 & 2.29 & 22.1 & $2 \mathrm{e}$ & Chalk \\
\hline Core 17 averages & & 15.1 & 2.13 & 31.4 & & \\
\hline $19-2,145.0$ & 585.45 & 20.9 & 1.96 & 40.9 & $2 \mathrm{e}$ & Chalk \\
\hline $20-3,106.0$ & 643.56 & 36.4 & 1.65 & 60.1 & $2 \mathrm{e}$ & Claystone \\
\hline $20-5,144.0$ & 646.94 & 18.9 & 2.03 & 38.4 & $2 \mathrm{e}$ & Nannofossil chalk \\
\hline Core 20 averages & & 27.6 & 1.84 & 49.2 & & \\
\hline $21-1,96.0$ & 649.96 & 23.5 & 1.62 & 38.0 & $3 \mathrm{a}$ & Silty claystone \\
\hline $21-3,103.0$ & 653.03 & 21.4 & 2.00 & 42.7 & $3 a$ & Claystone \\
\hline $21-5,91.0$ & 655.91 & 22.3 & 1.95 & 43.5 & $3 a$ & Silty claystone \\
\hline Core 21 averages & & 22.4 & 1.85 & 41.4 & & \\
\hline \multicolumn{7}{|l|}{ Hole 391B } \\
\hline $1-2,118.5$ & 2.88 & 52.1 & 1.49 & 77.6 & 1 & Clay \\
\hline $1-4,26.5$ & 4.97 & 57.2 & 1.63 & 93.6 & 1 & Clay \\
\hline $1-6,32.5$ & 8.03 & 53.5 & 1.65 & 88.4 & 1 & Silty clay \\
\hline Core 1 averages & & 54.2 & 1.59 & 86.5 & & \\
\hline \multicolumn{7}{|l|}{ Hole 391C } \\
\hline $1-1,69.5$ & 336.20 & 33.0 & 1.79 & 59.1 & 1 & Nannofossil ooze \\
\hline $1-2,105.5$ & 338.06 & 32.0 & 1.98 & 63.3 & 1 & Foraminifer ooze \\
\hline Core 1 averages & & 32.5 & 1.88 & 61.2 & & \\
\hline $2-1,142.0$ & 612.82 & 26.5 & 1.85 & 49.1 & $2 \mathrm{e}$ & Intraclastic chalk \\
\hline $2-3,140.0$ & 615.80 & 26.5 & 1.86 & 49.3 & $2 \mathrm{e}$ & Intraclastic chalk \\
\hline $2-5,131.0$ & 618.71 & 26.5 & 1.86 & 49.2 & $2 \mathrm{e}$ & Intraclastic chalk \\
\hline Core 2 averages & & 26.5 & 1.86 & 49.2 & & \\
\hline $4-1,138.0$ & 669.38 & 23.9 & 1.96 & 46.8 & $3 a$ & Micaceous claystone \\
\hline $5-1,117.5$ & 678.67 & 18.6 & 2.01 & 37.4 & $3 a$ & Variegated claystone \\
\hline $6-2,92.5$ & 689.92 & 21.2 & 1.98 & 42.0 & $3 a$ & Variegated claystone with silt laminae \\
\hline $6-4,93.5$ & 692.94 & 19.3 & 1.95 & 37.7 & $3 a$ & Claystone with silt laminae \\
\hline $6-6,93.5$ & 695.94 & 22.9 & 1.88 & 43.0 & $3 \mathrm{a}$ & Claystone with silt laminae \\
\hline Core 6 averages & & 21.1 & 1.97 & 40.9 & & \\
\hline $7-2,6.0$ & 726.56 & 25.8 & 1.92 & 49.5 & $3 b$ & Claystone \\
\hline $8-1,120.0$ & 783.20 & 27.3 & 1.87 & 51.3 & $3 b$ & Claystone \\
\hline
\end{tabular}


TABLE 10 - Continued

\begin{tabular}{|c|c|c|c|c|c|c|}
\hline $\begin{array}{c}\text { Sample } \\
\text { (Interval in } \mathrm{cm} \text { ) }\end{array}$ & $\begin{array}{l}\text { Depth in } \\
\text { Hole }(\mathrm{m})\end{array}$ & $\begin{array}{c}\text { Water Content } \\
(\%)\end{array}$ & $\begin{array}{l}\text { Wet Bulk Density } \\
\qquad(\mathrm{g} / \mathrm{cc})\end{array}$ & $\begin{array}{l}\text { Porosity } \\
(\%)\end{array}$ & $\begin{array}{l}\text { Lithologic } \\
\text { Unit }\end{array}$ & Lithology \\
\hline $9-1,40.0$ & 839.40 & 10.2 & 2.59 & 26.4 & $3 b$ & Claystone \\
\hline $9-1,79.0$ & 839.79 & 21.9 & 1.97 & 43.2 & $3 b$ & Claystone \\
\hline Section 1 averages & & 16.0 & 2.28 & 34.8 & & \\
\hline $9-2,79.0$ & 841.29 & 22.4 & 1.99 & 44.7 & $3 b$ & Claystone \\
\hline Core 9 averages & & 18.2 & 2.19 & 38.1 & & \\
\hline $10-1,121.0$ & 897.21 & 24.4 & 1.96 & 47.9 & $3 b$ & Claystone \\
\hline $10-2,24.0$ & 897.74 & 20.1 & 2.06 & 41.3 & $3 b$ & Claystone \\
\hline $10-3,74.0$ & 899.74 & 22.4 & 2.00 & 44.7 & $3 b$ & Claystone \\
\hline Core 10 averages & & 22.3 & 2.00 & 44.7 & & \\
\hline $11-1,43.0$ & 924.93 & 19.7 & 2.05 & 40.3 & $3 c$ & Calcareous claystone \\
\hline $11-3,37.0$ & 927.87 & 18.0 & 2.06 & 37.1 & $3 c$ & Calcareous claystone \\
\hline Core 11 averages & & 18.8 & 2.06 & 38.7 & & \\
\hline $12-1,141.0$ & 954.81 & 16.7 & 2.08 & 34.8 & $3 \mathrm{c}$ & Nannofossil limestone \\
\hline $12-6,68.0$ & 961.58 & 16.9 & 2.07 & 35.1 & $3 c$ & Calcareous claystone \\
\hline Core 12 averages & & 16.8 & 2.08 & 34.9 & & \\
\hline $14-2,92.5$ & 1002.92 & 17.0 & 2.08 & 35.3 & $4 a$ & Limestone \\
\hline $14-2,100.0$ & 1003.00 & 10.4 & 2.32 & 24.1 & $4 a$ & Limestone \\
\hline Section 2 averages & & 13.9 & 2.20 & 29.7 & & \\
\hline $14-3,121.0$ & 1004.71 & 16.6 & 2.17 & 36.0 & $4 \mathrm{a}$ & Claystone \\
\hline Core 14 averages & & 14.7 & 2.19 & 31.8 & & \\
\hline $15-1,81.0$ & 1010.81 & 13.2 & 2.25 & 29.6 & $4 a$ & Limestone \\
\hline $15-3,3.0$ & 1013.03 & 9.6 & 2.36 & 22.5 & $4 \mathrm{a}$ & Marly limestone \\
\hline Core 15 averages & & 11.4 & 2.30 & 26.1 & & \\
\hline $16-2,89.5$ & 1021.90 & 15.3 & 2.10 & 32.0 & $4 a$ & Limestone \\
\hline $16-4,89.5$ & 1024.90 & 13.5 & 2.20 & 29.7 & $4 a$ & Sandy siltstone \\
\hline Core 16 averages & & 14.4 & 2.15 & 30.9 & & \\
\hline $17-1,64.0$ & 1029.64 & 17.5 & 2.10 & 36.7 & $4 a$ & Sandy limestone \\
\hline $18-1,81.0$ & 1039.31 & 17.5 & 2.12 & 37.0 & $4 a$ & Sandy limestone \\
\hline $21-4,113.5$ & 1091.64 & 11.4 & 2.32 & 26.2 & $4 a$ & Calcareous claystone \\
\hline $24-2,106.0$ & 1126.56 & 11.4 & 2.26 & 25.8 & $4 b$ & Limestone \\
\hline $24-4,103.0$ & 1129.53 & 15.8 & 2.18 & 34.6 & $4 b$ & Claystone \\
\hline $24-6,117.0$ & 1132.67 & 15.0 & 2.19 & 32.8 & $4 b$ & Claystone \\
\hline Core 24 averages & & 14.2 & 2.21 & 31.1 & & \\
\hline $25-1,138.0$ & 1134.88 & 5.3 & 2.51 & 13.2 & $4 b$ & Limestone \\
\hline $25-3,95.5$ & 1137.46 & 13.8 & 2.22 & 30.6 & $4 \mathrm{~b}$ & Claystone \\
\hline Section 3 averages & & 13.9 & 2.21 & 30.7 & & \\
\hline Core 25 averages & & 11.0 & 2.31 & 24.9 & & \\
\hline $26-4,105.0$ & 1148.55 & 6.9 & 2.43 & 16.8 & $4 b$ & Limestone \\
\hline Core 26 averages & & 6.9 & 1.76 & 12.2 & & \\
\hline $27-2,8.0$ & 1154.08 & 16.3 & 2.13 & 34.6 & $4 \mathrm{~b}$ & Limestone \\
\hline $27-2,50.0$ & 1154.50 & 6.9 & 2.44 & 16.9 & $4 b$ & Limestone \\
\hline Section 2 averages & & 11.6 & 2.29 & 25.8 & & \\
\hline $27-4,57.0$ & 1157.57 & 11.7 & 1.02 & 11.9 & $4 b$ & Claystone \\
\hline $27-4,93.0$ & 1157.93 & 11.6 & 2.30 & 26.5 & $4 b$ & Limestone \\
\hline Section 4 averages & & 11.6 & 1.65 & 19.2 & & \\
\hline Core 27 averages & & 11.6 & 1.97 & 22.5 & & \\
\hline $28-2,129.0$ & 1164.79 & 8.4 & 2.39 & 20.0 & $4 b$ & Limestone \\
\hline $28-4,119.0$ & 1167.69 & 12.3 & 2.25 & 27.8 & $4 b$ & Limestone \\
\hline Core 28 averages & & 10.9 & 2.32 & 23.9 & & \\
\hline $29-3,29.0$ & 1174.79 & 9.8 & 2.32 & 22.6 & $4 \mathrm{~b}$ & Limestone \\
\hline $30-2,85.0$ & 1183.35 & 15.5 & 2.15 & 33.5 & $4 b$ & Limestone \\
\hline $30-4,81.0$ & 1186.31 & 9.7 & 2.35 & 22.7 & $4 b$ & Limestone \\
\hline $30-4,117.0$ & 1186.67 & 13.5 & 2.22 & 30.1 & $4 b$ & Claystone \\
\hline Section 4 averages & & 11.6 & 2.29 & 26.4 & & \\
\hline Core 30 averages & & 12.9 & 2.24 & 28.7 & & \\
\hline $31-2,104.0$ & 1193.04 & 13.6 & 2.22 & 30.2 & $4 b$ & Limestone \\
\hline $31-3,34.0$ & 1193.84 & 8.5 & 2.38 & 20.3 & $4 b$ & Limestone \\
\hline $31-4,28.0$ & 1195.28 & 12.9 & 2.24 & 28.9 & $4 b$ & Limestone \\
\hline $31-6,83.0$ & 1198.83 & 9.1 & 2.35 & 21.3 & $4 b$ & Limestone \\
\hline Core 31 averages & & 11.0 & 2.30 & 25.1 & & \\
\hline $32-2,61.0$ & 1202.11 & 8.0 & 2.42 & 19.4 & $4 b$ & Limestone \\
\hline $32-3,57.0$ & 1203.57 & 8.9 & 2.39 & 21.1 & $4 \mathrm{~b}$ & Clayey limestone \\
\hline $32-4,145.0$ & 1205.95 & 8.0 & 2.39 & 19.1 & $4 b$ & Clayey limestone \\
\hline Core 32 averages & & 8.3 & 2.40 & 19.9 & & \\
\hline $33-1,96.0$ & 1210.46 & 5.3 & 2.51 & 13.3 & $4 b$ & Limestone \\
\hline $33-3,37.0$ & 1212.87 & 9.0 & 2.36 & 21.2 & $4 b$ & Clayey limestone \\
\hline Core 33 averages & & 7.1 & 2.44 & 17.2 & & \\
\hline $34-2,138.0$ & 1221.88 & 9.4 & 2.38 & 22.3 & $4 \mathrm{c}$ & Clayey limestone \\
\hline $34-3,57.0$ & 1222.57 & 7.5 & 2.43 & 18.1 & $4 c$ & Clayey limestone \\
\hline $34-4,88.0$ & 1224.38 & 9.5 & 2.38 & 22.7 & $4 c$ & Clayey limestone \\
\hline
\end{tabular}


TABLE 10 - Continued

\begin{tabular}{|c|c|c|c|c|c|c|}
\hline $\begin{array}{c}\text { Sample } \\
\text { (Interval in } \mathrm{cm} \text { ) }\end{array}$ & $\begin{array}{l}\text { Depth in } \\
\text { Hole }(\mathrm{m})\end{array}$ & $\begin{array}{l}\text { Water Content } \\
(\%)\end{array}$ & $\begin{array}{l}\text { Wet Bulk Density } \\
(\mathrm{g} / \mathrm{cc})\end{array}$ & $\begin{array}{l}\text { Porosity } \\
(\%)\end{array}$ & $\begin{array}{l}\text { Lithologic } \\
\text { Unit }\end{array}$ & Lithology \\
\hline $35-1,92.0$ & 1229.42 & 7.9 & 2.42 & 19.2 & $4 c$ & Clayey nannofossil limestone \\
\hline $35-2,124.0$ & 1231.24 & 11.4 & 2.32 & 26.4 & $4 c$ & Clayey nannofossil limestone \\
\hline $35-3,31.0$ & 1231.81 & 9.5 & 2.38 & 22.6 & $4 \mathrm{c}$ & Clayey nannofossil limestone \\
\hline Core 35 averages & & 9.6 & 2.37 & 22.7 & & \\
\hline $36-2,24.0$ & 1239.74 & 11.5 & 2.39 & 26.4 & $4 \mathrm{c}$ & Clayey nannofossil limestone \\
\hline $36-4,92.0$ & 1243.42 & 7.9 & 2.42 & 19.1 & $4 \mathrm{c}$ & Clayey nannofossil limestone \\
\hline $36-5,51.0$ & 1244.51 & 10.9 & 2.33 & 25.4 & $4 \mathrm{c}$ & Clayey nannofossil limestone \\
\hline Core 36 averages & & 10.1 & 2.35 & 23.6 & & \\
\hline $37-2,136.0$ & 1250.36 & 9.7 & 2.35 & 22.8 & $4 \mathrm{c}$ & Clayey limestone \\
\hline $38-2,129.0$ & 1259.79 & 8.9 & 2.38 & 21.2 & $4 \mathrm{~d}$ & Clayey limestone \\
\hline $38-3,5.0$ & 1260.05 & 9.7 & 2.34 & 22.6 & $4 d$ & Clayey limestone \\
\hline $38-4,80.0$ & 1262.30 & 8.0 & 2.42 & 19.3 & $4 d$ & Clayey limestone \\
\hline Core 38 averages & & 8.9 & 2.38 & 21.1 & & \\
\hline $39-2,33.0$ & 1268.33 & 8.6 & 2.40 & 20.7 & $4 d$ & Clayey limestone \\
\hline $39-4,102.0$ & 1272.02 & 7.7 & 2.42 & 18.6 & $4 d$ & Clayey limestone \\
\hline Core 39 averages & & 8.2 & 2.41 & 19.7 & & \\
\hline $40-2,49.0$ & 1277.99 & 5.8 & 1.93 & 11.2 & $4 d$ & Clayey limestone \\
\hline $40-4,29.0$ & 1280.79 & 5.2 & 3.72 & 19.2 & $4 d$ & Clayey limestone \\
\hline Core 40 averages & & 5.5 & 2.83 & 15.2 & & \\
\hline $41-1,24.0$ & 1285.74 & 10.1 & 2.34 & 23.7 & $4 \mathrm{~d}$ & Clayey limestone \\
\hline $41-4,128.0$ & 1291.28 & 7.7 & 2.41 & 18.5 & $4 \mathrm{~d}$ & Clayey limestone \\
\hline Core 41 averages & & 8.9 & 2.37 & 21.1 & & \\
\hline $42-2,107.0$ & 1297.57 & 9.3 & 2.36 & 21.9 & $4 d$ & Clayey limestone \\
\hline $42-4,60.0$ & 1300.10 & 6.3 & 2.48 & 15.6 & $4 d$ & Clayey limestone \\
\hline Core 42 averages & & 7.8 & 2.42 & 18.7 & & \\
\hline $43-1,92.0$ & 1305.42 & 7.5 & 2.42 & 18.1 & $4 d$ & Clayey limestone \\
\hline $43-3,36.0$ & 1307.86 & 8.3 & 2.39 & 19.8 & $4 d$ & Clayey limestone \\
\hline Core 43 averages & & 7.9 & 2.42 & 19.0 & & \\
\hline $44-2,136.0$ & 1316.86 & 6.7 & 2.45 & 16.4 & $4 \mathrm{~d}$ & Clayey limestone \\
\hline $44-4,135.0$ & 1319.85 & 6.4 & 2.47 & 15.7 & $4 d$ & Clayey limestone \\
\hline $44-6,119.0$ & 1322.69 & 7.2 & 2.43 & 17.5 & $4 d$ & Clayey limestone \\
\hline Core 44 averages & & 6.8 & 2.45 & 16.5 & & \\
\hline $45-1,63.0$ & 1324.13 & 5.9 & 2.46 & 14.6 & $5 \mathrm{a}$ & White limestone with greenish stringers \\
\hline $45-2,31.0$ & 1325.31 & 6.4 & 2.45 & 15.7 & $5 \mathrm{a}$ & White limestone with greenish stringers \\
\hline $45-3,68.0$ & 1327.18 & 5.8 & 2.48 & 14.3 & 5 a & Greenish gray limestone \\
\hline Core 45 averages & & 6.2 & 2.46 & 14.1 & & \\
\hline $46-1,88.0$ & 1333.88 & 9.8 & 2.35 & 23.1 & $5 \mathrm{a}$ & Clayey limestone \\
\hline $46-1,137.0$ & 1334.37 & 6.5 & 2.47 & 16.9 & $5 \mathrm{a}$ & Calcareous claystone \\
\hline Core 46 averages & & 8.2 & 2.41 & 19.6 & & \\
\hline $47-1,59.0$ & 1343.09 & 18.0 & 2.12 & 38.1 & $5 \mathrm{a}$ & Calcareous claystone \\
\hline $48-2,88.5$ & 1354.39 & 4.4 & 2.54 & 11.3 & $5 \mathrm{a}$ & Greenish gray limestone \\
\hline $49-2,16.0$ & 1363.16 & 1.7 & 2.65 & 4.5 & $5 \mathrm{a}$ & Greenish gray limestone \\
\hline $49-2,89.0$ & 1363.89 & 9.8 & 2.35 & 23.1 & $5 \mathrm{a}$ & Greenish gray limestone \\
\hline Core 49 averages & & 5.8 & 2.50 & 13.8 & & \\
\hline $50-1,83.0$ & 1371.83 & 7.2 & 2.47 & 17.7 & $5 b$ & Calcareous claystone \\
\hline $51-2,90.0$ & 1382.90 & 9.4 & 2.41 & 22.7 & $5 b$ & Calcareous claystone \\
\hline $52-2,98.0$ & 1392.48 & 13.5 & 2.26 & 30.6 & $5 b$ & Calcareous claystone \\
\hline $52-4,86.0$ & 1395.36 & 7.5 & 2.44 & 18.2 & $5 b$ & Calcareous claystone \\
\hline Core 52 averages & & 10.5 & 2.35 & 24.4 & & \\
\hline
\end{tabular}

meters thick and is composed of silty clay with nannofossil ooze and calcareous sand intercalations.

Core 3 , Section 1 through Core 20 consists of approximately 500 meters of Miocene sediments. The lithology is mainly an alternating chalk breccia and claystone with a few thin limestone beds; only the uppermost few meters are ooze. Grain size and sorting of the Miocene sediments vary considerably, as do the abundance and diversity of foraminifer tests. The evidence suggests that most of the Miocene sediment has been displaced by gravity flow to below the CCD. (See also "Reworking and Depositional Environment,'” below).

Despite dissolution, gravity flow deposition, and reworking, a rather detailed foraminiferal biostratigraphy could be established. The zonation follows Blow (1967). Table 14 summarizes the lithology, foraminifer test dissolution, type of reworking, and the foraminifer biostratigraphy in the Miocene-Quaternary interval of Hole $391 \mathrm{~A}$.

\section{Quaternary Foraminifers}

Assemblages of rich and well-preserved planktonic foraminifers occur, with some dissolution features in Samples 391A-1-5, 60-62 cm, and 1, CC; dissolution impoverished assemblages occur in Samples 391A-2, CC, and 3-1, 134-136 cm. All four samples contain Globorotalia truncatulinoides, indicative of Quaternary sediments. In addition, Samples 391A-1-5, 60-62 cm, and 1 , CC also have $G$. tosaensis which indicates lower Pleistocene sediments (N.22, G. truncatulinoides Zibe). Additional taxa in the samples are $G$. crassaformis, $G$. hirsuta, G. multicamerata, G. tumida, G. menardii, $G$. inflata (relatively rare), Globigerina dutertrei, Globigerinoides trilobus, G. extremus, G. sacculifera, $G$. 
TABLE 11

Average Water Content for Each Lithologic Unit, Site 391

\begin{tabular}{|c|c|c|c|c|c|c|c|c|c|}
\hline \multirow[b]{2}{*}{$\begin{array}{l}\text { Lithologic } \\
\text { Unit }\end{array}$} & \multicolumn{3}{|c|}{ Hole 391A } & \multicolumn{3}{|c|}{ Hole 391C } & \multicolumn{3}{|c|}{ Hole 391B } \\
\hline & $\begin{array}{l}\text { Average Water } \\
\text { Content } \\
(\%)\end{array}$ & $\begin{array}{c}\text { Range } \\
(\%)\end{array}$ & $\begin{array}{l}\text { No. of } \\
\text { Measure- } \\
\text { ments }\end{array}$ & $\begin{array}{c}\text { Average Water } \\
\text { Content } \\
(\%)\end{array}$ & $\begin{array}{c}\text { Range } \\
(\%)\end{array}$ & $\begin{array}{l}\text { No. of } \\
\text { Measure- } \\
\text { ments }\end{array}$ & $\begin{array}{l}\text { Average Water } \\
\text { Content } \\
(\%)\end{array}$ & $\begin{array}{c}\text { Range } \\
(\%)\end{array}$ & $\begin{array}{l}\text { No. of } \\
\text { Measure- } \\
\text { ments }\end{array}$ \\
\hline 1 & 26.3 & $24.4-28.2$ & 2 & 32.5 & $32.0-33.0$ & 2 & 54.5 & $52.7-57.2$ & 3 \\
\hline $2 a$ & 26.7 & $24.7-30.0$ & 3 & & & & & & \\
\hline $2 \mathrm{~b}$ & 26.9 & $20.5-31.1$ & 6 & & & & & & \\
\hline $2 \mathrm{c}$ & 43.1 & $41.2-42.4$ & 4 & & & & & & \\
\hline $2 d$ & 26.1 & $22.4-27.5$ & 7 & & & & & & \\
\hline $2 \mathrm{e}$ & 24.3 & $9.7-40.4$ & 7 & 26.5 & $26.5-26.5$ & 3 & & & \\
\hline $3 a$ & 22.4 & $21.4-23.5$ & 3 & 21.2 & $18.6-23.9$ & 5 & & & \\
\hline $3 b$ & & & & 21.8 & $10.2-27.3$ & 8 & & & \\
\hline $3 c$ & & & & 17.8 & $16.7-19.7$ & 4 & & & \\
\hline $4 a$ & & & & 14.2 & $9.6-17.0$ & 10 & & & \\
\hline $4 b$ & & & & 10.8 & $5.3-16.3$ & 26 & & & \\
\hline $4 c$ & & & & 9.5 & $7.5-11.5$ & 10 & & & \\
\hline $4 d$ & & & & 7.7 & $5.2-10.1$ & 16 & & & \\
\hline $5 a$ & & & & 7.6 & $1.7-18.0$ & 9 & & & \\
\hline $5 b$ & & & & 9.4 & $7.2-13.5$ & 4 & & & \\
\hline
\end{tabular}

TABLE 12

Average Wet Bulk Density for Each Lithologic Unit, Site 391

\begin{tabular}{|c|c|c|c|c|c|c|c|c|c|}
\hline \multirow[b]{2}{*}{$\begin{array}{l}\text { Lithologic } \\
\text { Unit }\end{array}$} & \multicolumn{3}{|c|}{ Hole 391A } & \multicolumn{3}{|c|}{ Hole 391C } & \multicolumn{3}{|c|}{ Hole 391B } \\
\hline & $\begin{array}{c}\text { Average Wet } \\
\text { Bulk Density } \\
(\mathrm{g} / \mathrm{cc})\end{array}$ & $\begin{array}{l}\text { Range } \\
(\mathrm{g} / \mathrm{cc})\end{array}$ & $\begin{array}{l}\text { No. of } \\
\text { Measure- } \\
\text { ments }\end{array}$ & $\begin{array}{c}\text { Average Wet } \\
\text { Bulk Density } \\
(\mathrm{g} / \mathrm{cc})\end{array}$ & $\begin{array}{l}\text { Range } \\
(\mathrm{g} / \mathrm{cc})\end{array}$ & $\begin{array}{l}\text { No. of } \\
\text { Measure- } \\
\text { ments }\end{array}$ & $\begin{array}{l}\text { Average Wet } \\
\text { Bulk Density } \\
\text { (g/cc) }\end{array}$ & $\begin{array}{r}\text { Range } \\
(\mathrm{g} / \mathrm{cc})\end{array}$ & $\begin{array}{l}\text { No. of } \\
\text { Measure- } \\
\text { ments }\end{array}$ \\
\hline 1 & 1.59 & $1.44-1.73$ & 2 & 1.88 & $1.79-1.98$ & 2 & 1.59 & $1.49-1.65$ & 3 \\
\hline $2 a$ & 1.88 & $1.79-1.94$ & 3 & & & & & & \\
\hline $2 \mathrm{~b}$ & 1.87 & $1.77-2.00$ & 6 & & & & & & \\
\hline $2 \mathrm{c}$ & 1.51 & $1.47-1.55$ & 4 & & & & & & \\
\hline $2 d$ & 1.84 & $1.81-1.93$ & 7 & & & & & & \\
\hline $2 \mathrm{e}$ & 1.91 & $1.57-2.29$ & 7 & 1.85 & $1.85-1.86$ & 3 & & & \\
\hline $3 a$ & 1.86 & $1.62-2.00$ & 3 & 1.96 & $1.88-2.01$ & 5 & & & \\
\hline $3 \mathrm{~b}$ & & & & 1.92 & $1.87-2.59$ & 8 & & & \\
\hline $3 c$ & & & & 2.07 & $2.05-2.08$ & 4 & & & \\
\hline $4 \mathrm{a}$ & & & & 2.19 & $2.08-2.36$ & 10 & & & \\
\hline $4 \mathrm{~b}$ & & & & 2.26 & $1.02-2.51$ & 26 & & & \\
\hline $4 \mathrm{c}$ & & & & 2.37 & $2.32-2.43$ & 10 & & & \\
\hline $4 d$ & & & & 2.31 & $1.93-3.72$ & 16 & & & \\
\hline $5 \mathrm{a}$ & & & & 2.43 & $2.12-2.65$ & 9 & & & \\
\hline $5 b$ & & & & 2.39 & $2.26-2.45$ & 4 & & & \\
\hline
\end{tabular}

TABLE 13

Average Porosity for Each Lithologic Unit, Site 391

\begin{tabular}{|c|c|c|c|c|c|c|c|c|c|}
\hline \multirow[b]{2}{*}{$\begin{array}{l}\text { Lithologic } \\
\text { Unit }\end{array}$} & \multicolumn{3}{|c|}{ Hole 391A } & \multicolumn{3}{|c|}{ Hole 391C } & \multicolumn{3}{|c|}{ Hole 391B } \\
\hline & $\begin{array}{c}\text { Average } \\
\text { Porosity } \\
(\%)\end{array}$ & $\begin{array}{c}\text { Range } \\
(\%)\end{array}$ & $\begin{array}{l}\text { No. of } \\
\text { Measure- } \\
\text { ments }\end{array}$ & $\begin{array}{c}\text { Average } \\
\text { Porosity } \\
(\%)\end{array}$ & $\begin{array}{c}\text { Range } \\
(\%)\end{array}$ & $\begin{array}{l}\text { No. of } \\
\text { Measure- } \\
\text { ments }\end{array}$ & $\begin{array}{c}\text { Average } \\
\text { Porosity } \\
\text { (\%) }\end{array}$ & $\begin{array}{l}\text { Range } \\
(\%)\end{array}$ & $\begin{array}{l}\text { No. of } \\
\text { Measure- } \\
\text { ments }\end{array}$ \\
\hline 1 & 41.9 & $48.7-35.1$ & 6 & 62.3 & $61.2-63.3$ & 2 & 86.5 & $77.6-93.6$ & 3 \\
\hline $2 a$ & 50.0 & $48.0-53.7$ & 3 & & & & & & \\
\hline $2 b$ & 50.1 & $41.1-54.4$ & 6 & & & & & & \\
\hline $2 c$ & 65.0 & $63.9-67.3$ & 4 & & & & & & \\
\hline $2 d$ & 48.1 & $43.3-49.7$ & 7 & & & & & & \\
\hline $2 \mathrm{e}$ & 44.3 & $22.1-63.3$ & 7 & 49.2 & $49.1-49.3$ & 3 & & & \\
\hline $3 a$ & 41.4 & $38.0-43.5$ & 3 & 42.1 & $37.4-46.8$ & 5 & & & \\
\hline $3 \mathrm{~b}$ & & & & 43.6 & $26.4-51.3$ & 8 & & & \\
\hline $3 c$ & & & & 36.8 & $34.8-40.3$ & 4 & & & \\
\hline $4 a$ & & & & 30.9 & $24.1-36.7$ & 10 & & & \\
\hline $4 b$ & & & & 24.1 & $11.9-34.6$ & 26 & & & \\
\hline $4 c$ & & & & 22.5 & $18.1-26.4$ & 10 & & & \\
\hline $4 d$ & & & & 18.7 & $11.2-22.6$ & 16 & & & \\
\hline $5 \mathrm{a}$ & & & & 17.9 & $4.5-38.1$ & 9 & & & \\
\hline $5 b$ & & & & 22.3 & $17.7-30.6$ & 4 & & & \\
\hline
\end{tabular}




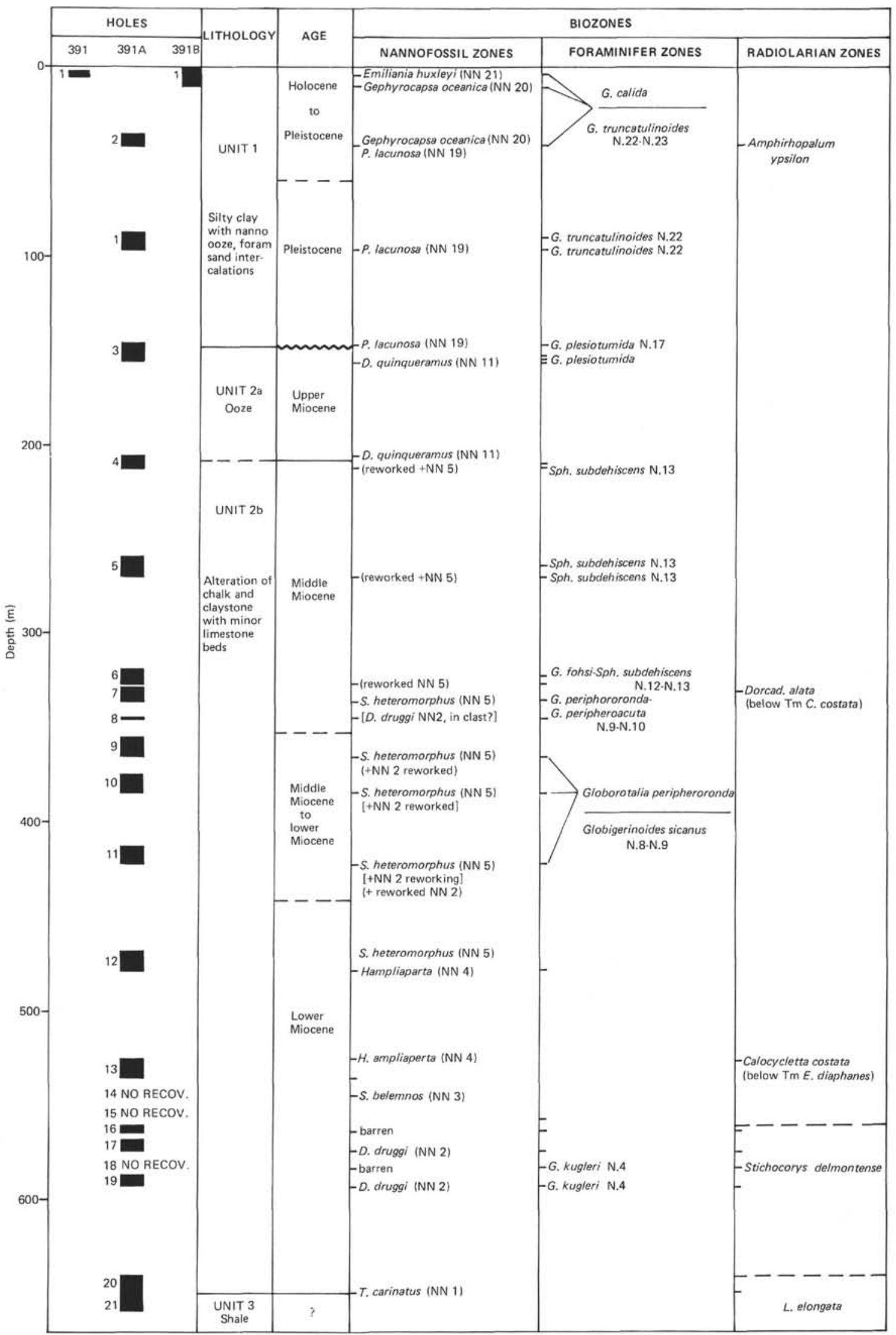

Figure 20. Biostratigraphic summary, 0-670 meters, Site 391. 


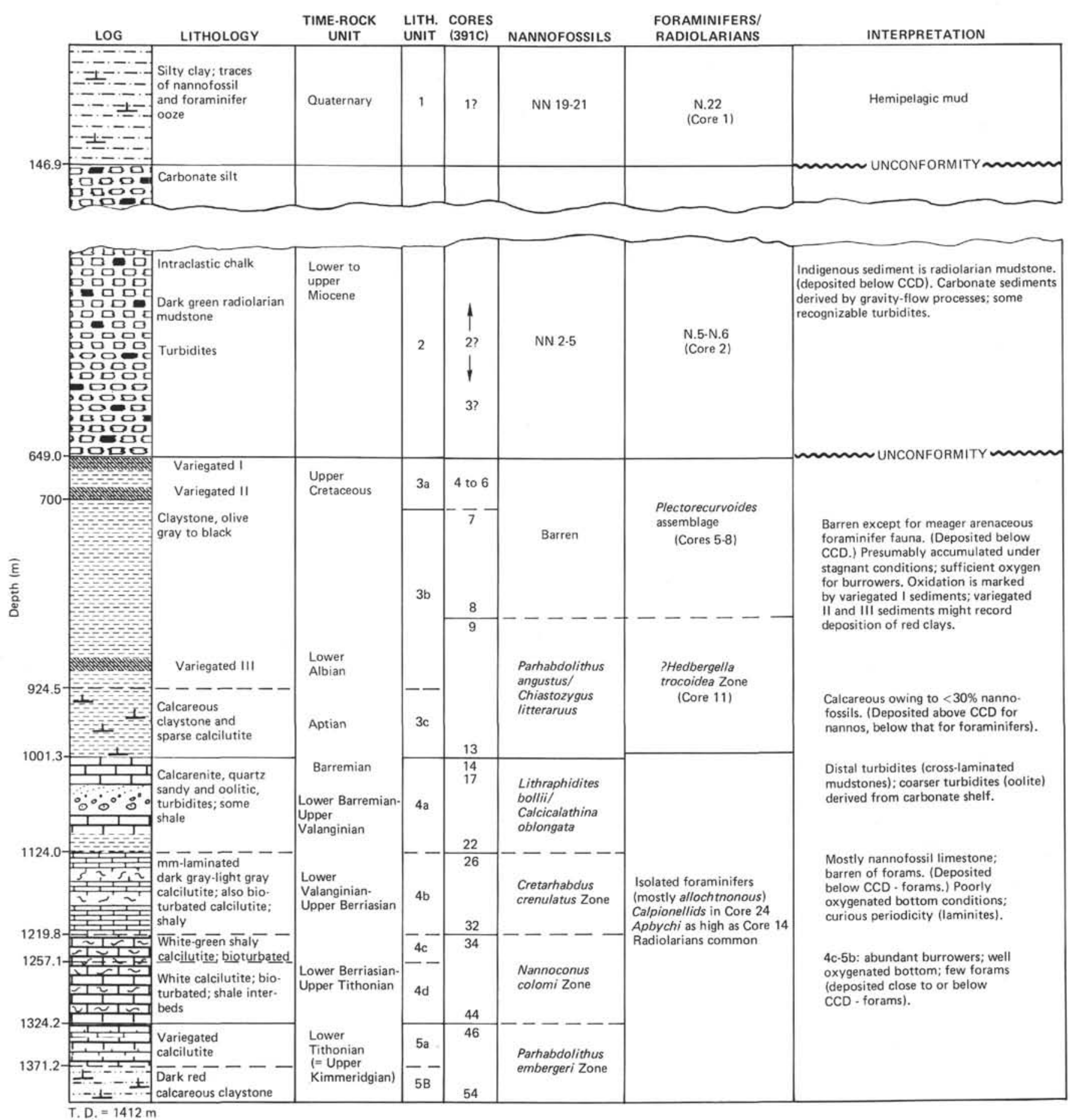

Figure 21. Biostratigraphic summary, Hole 391C.

ruber, G. conglobatus, Candeina nitida, Pulleniatina obliquiloculata, and sphaeroidinella dehiscens.

Few benthic foraminifers were found in Hole 391A. They are mostly Cibicides wuellerstorfi and Pullenia which may be of deep-water origin.

\section{Miocene Planktonic Foraminifers}

Out of 22 core samples studied from between \pm 150 and 650 meters, 10 yielded sufficiently diversified assemblages to allow detailed Miocene biostratigraphic determinations.
Six yielded Miocene assemblages with less biostratigraphic value and six others contain no foraminifers.

Samples 391A-3-4, 33-34 cm;

3-6, $40-42 \mathrm{~cm} ; 3$, CC: Globorotalia plesiotumida Zone, N.17, upper Miocene

Diversified assemblage with the zonal markers Globorotalia acostaensis, G. miocenica, G. plesiotumida, G. margaritae, G. aff. miozea dibaoensis, Globigerinoides extremus, and Candeina nitida. The overlap in ranges 
indicates Zone N.17. Additional species are Globorotalia menardii, Hastigerina aequilateralis, Globoquadrina dehiscens, and $G$. altispira.

Sample 391A-4-4, 60-62 cm:

The presence of Globorotalia siakensis indicates sediments not younger than N.14, middle Miocene.

Sample 391A-4-CC; 5-2, 117-119 cm;

5, CC; 6-4, 80-82 cm: Sphaeroidinella subdehiscens Zone (N.13), middle Miocene

The presence of Hastigerina aequilateralis ( $H$. siphonifera group sensu Blow), Globigerinoides subquadratus (one specimen only), Globorotalia fohsi, G. menardii-praemenardii and $G$. siakensis indicate Zone N.13 in Blow's zonation. Sample 6-4, 80-82 cm, with only Globorotalia fohsi and G. siakensis may belong to Zones N.12-13.

Additional species are Globorotalia aff. continuosa, $G$. scitula group, Globigerina aff. praebulloides, Sphaeroidinella seminula, Globigerinoides obliquus, and Globoquadrina supp.

Sample 391A-7 CC: Globortalia peripheroronda-G. G. peripheroacuta zones (N.9-N.10)

Diagnostic species are Globorotalia peripheroronda, $G$. peripheroacuta, G. archeomenardii, and Globigerinoides sicanus, which indicates middle Miocene, Zones N.9-N-10.

Samples 391A-9, CC; 10, CC, 11, CC:

Globigerinoides sicanus-Globorotalia peripheroronda zones (N.8-N.9), early-middle Miocene

These samples contain Praeorbulina glomerosa,
Globigerinoides sicanus, Globigerinatella insueta, Globorotalia peripheroronda, and $G$. archeomenardii which place them in Zones N.8-N.9 at the boundary of lower and middle Miocene.

Additional species are Globorotalia siakensis, G. scitula, $G$. aff. continuosa, Cassigerinella chipolensis, Globigerina venezuelana, and Globoquadrina supp.

Samples 391A-18, CC; 19, CC: Globorotalia kugleri Zone (N.4), lower Miocene

Sample 19, CC contains foraminifers only in the 60-125 $\mu \mathrm{m}$ fraction. Species include Globorotalia kugleri and Globigerina praebulloides. This indicates that Sample 19, CC falls in the lower Miocene Zone N.4. Sample 18, CC with Globigerinoides primordius also may belong to this zone.

\section{Miocene Benthic Foraminifers}

The Miocene environment at Site 391 was unfavorable to most of the benthic foraminifers. This is evidenced by numerous intervals lacking foraminifers and dissolution features in foraminifers in other beds. Moreover, the present water depth of over $5 \mathrm{~km}$ and the Miocene CCD was above $4 \mathrm{~km}$. A few arenaceous foraminifers might have lived but we did not find any of their tests. In our opinion, the calcareous benthic specimens present in the sediment are part of displaced faunas which escaped dissolution because they were rapidly buried. The same applies to the planktonic assemblages.

Among deep-water taxa of probable Miocene age are: Cibicides wuellerstorfi and Uvigerina senticosa. Miocene taxa from much shallower environments include Cibicides lobatulus, Siphonina, Nonionella, Nonion affine,

TABLE 14

Summary of Lithology, Foraminifer Test Dissolution, Reworking and Biostratigraphy in Hole 391A, Cores 1 Through 20

\begin{tabular}{|c|c|c|c|c|c|c|c|c|}
\hline \multirow{2}{*}{$\begin{array}{c}\text { Sample } \\
\text { (Interval in } \mathrm{cm} \text { ) }\end{array}$} & \multirow[b]{2}{*}{ Lithology } & \multicolumn{3}{|c|}{ Test Dissolution } & \multicolumn{2}{|c|}{ Reworking } & \multirow{2}{*}{\multicolumn{2}{|c|}{$\begin{array}{c}\text { Foraminifer } \\
\text { Biostratigraphy }\end{array}$}} \\
\hline & & Minor & Severe & Total & Cret. Eocene & Neogene & & \\
\hline $\begin{array}{l}2, \mathrm{CC} \\
1-5,60-62 \\
1, \mathrm{CC} \\
3-1,134-136 \\
3-4,33-35\end{array}$ & $\begin{array}{l}\text { Foraminifer sand } \\
\text { Silty clay } \\
\text { Calcareous clay } \\
\text { Calcareous silt }\end{array}$ & $\begin{array}{l}\mathrm{X} \\
\mathrm{X}\end{array}$ & $\begin{array}{l}X \\
X\end{array}$ & & $\mathrm{X}$ & $\begin{array}{l}\text { N.15-N.19 } \\
\text { N.15-N.19 }\end{array}$ & $\begin{array}{l}\text { N.22-N.23 } \\
\text { N.22 } \\
\text { N.22 } \\
\text { N.22 } \\
\text { N.17 }\end{array}$ & $\begin{array}{l}3 \text { Quaternary } \\
\text { Lower Quaternary } \\
\text { Lower Quaternary } \\
\text { Lower Quaternary } \\
\text { Upper Miocene }\end{array}$ \\
\hline $\begin{array}{l}5-2,117-119 \\
5, \mathrm{CC} \\
6-4,80-82 \\
6, \mathrm{CC} \\
7, \mathrm{CC} \\
8, \mathrm{CC} \\
\end{array}$ & $\begin{array}{l}\text { Olive chalk, green clasts } \\
\text { Gray chalk, green clasts } \\
\text { Marly chalk, tiny clasts } \\
\text { Olive chalk } \\
\text { Radiolarian mudstone } \\
\text { Radiolarian mudstone }\end{array}$ & $\begin{array}{l}X \\
X \\
X \\
X\end{array}$ & $\mathrm{X}$ & & $\begin{array}{l}\mathrm{X} \\
\mathrm{X}\end{array}$ & $?$ & $\begin{array}{l}\text { N.13 } \\
\text { N.13 } \\
\text { N.12-N.13 } \\
\text { N.9-N.10 }\end{array}$ & $\begin{array}{l}\text { Middle Miocene } \\
\text { Middle Miocene } \\
3 \text { Middle Miocene } \\
\text { Middle Miocene }\end{array}$ \\
\hline $\begin{array}{l}16, \mathrm{CC} \\
17, \mathrm{CC} \\
18, \mathrm{CC} \\
19, \mathrm{CC} \\
20, \mathrm{CC}\end{array}$ & $\begin{array}{l}\text { Green-bluish claystone } \\
\text { Dark green mudstone } \\
\text { Dark green mudstone } \\
\text { Marly chalk } \\
\text { Gray chalk, white-green specks }\end{array}$ & & $\begin{array}{l}X \\
X\end{array}$ & $\begin{array}{l}X \\
X\end{array}$ & & & $\begin{array}{l}\text { N.4 } \\
\text { N.4 }\end{array}$ & $\begin{array}{l}\text { Lower Miocene } \\
\text { Lower Miocene }\end{array}$ \\
\hline
\end{tabular}


Elphidium, Rectuvigerina, Angulogerina, Eponides, Gyroidina, Lenticulina, and Tretomphalus.

\section{Reworked Specimens and Depositional Environments}

Reworked planktonic and/or benthic foraminifers occur in 13 out of the 26 Miocene-Quaternary samples studied. The ages of these specimens range from early Cretaceous to early Pliocene. Table 14 shows samples which have reworked Cretaceous-Eocene specimens and reworked Neogene specimens.

Reworked Cretaceous fossils (mostly Upper Cretaceous planktonic foraminifers) occur throughout the section. The occurrence of the shallow-water, Lower Cretaceous benthonic form, Coskinolinoids, in Sample 11, CC is particularly noteworthy.

Reworked Eocene fossils outnumber both Cretaceous and Neogene forms. Some washed samples are composed almost totally of lower-middle Eocene planktonic forms for example Samples 4-1, 97-99 cm, and 5-2, 117-119 cm. The sediment source probably was a planktonic ooze on the nearby slope or the Blake Plateau.

Most of the reworked Eocene benthic foraminifers seem to be from very shallow environments, e.g., the larger foraminifers in Core 12, Sections 1-6. Alveolina, Discocyclina, Assilina, Aktinocyclina, Amphistegina, and various miliolids are tentatively identified. The source of these Paleocene-Eocene shallow-water benthic forms may be the Bahama channels where shallow marine Tertiary sediments crop out.

The displaced Neogene benthic foraminifers comprise both deep- and shallow-water types suggesting both the Blake Plateau and the Bahama channels as possible source areas. The reworked Neogene planktonic foraminifers become progressively younger upward in the sediment column (Table 14). During early-middle Miocene time (close to the boundary) early Miocene planktonic foraminifers were being eroded; by middle Miocene time, early-middle Miocene boundary fossils became re-excavated. By late Miocene time, early-middle Miocene fossils were reworked, and late Miocene-early Pliocene plankton contaminated the in situ Quaternary assemblage. Apparently the individual gravity flows were scouring to only a limited depth, and not re-excavating much deeper older beds.

On the basis of the preceding evidence, we conclude that:

1. Site 391 was below the CCD during Miocene-Quaternary time.

2. Nearly all foraminifers are allochthonous; the foraminiferal biostratigraphy was developed on the basis of an orderly displaced fauna which becomes younger upward. This implies that the biozonation gives a maximum age for the rocks dated: a maximum, however, which probably is reasonably accurate in terms of zones.

3. The sediment had at least two source areas, the Bahama channels and the Blake Plateau as both deep- and shallow-water foraminifers are found in the reworked faunas.

\section{Hole 391B}

Drilling at Hole 391B recovered 9.3 meters of silty clay (lithologic unit 1, see Figure 20) taken immediately below the sea floor. Two samples, 391B-1-6, 70-72 cm, and
391B-1, CC, were studied; both contain moderately well preserved foraminifer assemblages, but tests are dissolved as would be expected at this depth below the CCD. Less dissolution-resistant species apparently have disappeared and mostly tiny specimens are left (especially Sample 391B-1-6, 70-72 cm).

The fauna indicates the Hole 391B sediments are Quaternary Zone N.22, or possibly Zone N.23. Species found are Globorotalia truncatulinoides, G. crassaformis, $G$. inflata, $G$. tumida, $G$. hirsuta, Pulleniatina obliquiloculata, Globigerinoides sacculifera, G. trilobus, $G$. ruber, $G$. conglobatus, $G$. obliquus, Hastigerina aequilateralis, Candeina nitida, Globigerina dutertrei, Globigerinita naparimaensis. Deep-water benthic foraminifers include Nonion pompiloides, Pullenia sp., Pyrgo, Eponides, Cibicides wuellerstorfi. Cibicides spp. and ostracodes may have come from shallower water. Sphaeroidinella seminula and Globigerina nepenthes are reworked Neogene species.

\section{Hole 391C}

\section{Introduction}

One of our main objectives at Site 391, above one of the oldest magnetic anomalies in the North Atlantic Ocean, was penetration of Middle or even Lower Jurassic marine sediments. So far only Upper Jurassic sediments have been positively identified in the ocean floor; the identification of Callovian beds in Site 100, Leg 11, is uncertain.

A modest Late Jurassic foraminifer fauna, recovered during Leg 11, has been skillfully studied by Luterbacher (1972). The presence there of Epistomina species (including E. gr. mosquensis) indicated that the rocks were (Middle-) Upper Jurassic. Aptychi-Saccoma faunas, together with nannofossils, calionellids, and dinoflagellates provided the detailed biostratigraphic framework.

Recovery of a deep marine pre-Late. Jurassic foraminifer fauna, close to the western Atlantic Basin margin, would add considerably to our knowledge of Jurassic deeper water faunas $(2-4 \mathrm{~km}$ water depth according to the empirical equations on depth of the ocean floor as a function of the age of the oceanic crust, e.g., Le Pichon et al., 1973, fig. 18). Previously, as Luterbacher (1972) has pointed out, Jurassic deep-water faunas were known mostly from Italy (Farinacci, 1965) and from Leg 11 sediments. More recently, drilling at Site 367 (Leg 41) penetrated a section similar to that drilled on Leg 11.

Study of Site 391 materials might also provide more data on the geographic distribution of Jurassic foraminifers (Gordon, 1970; Gradstein, in press), and add to the Jurassic foraminifer biostratigraphy. The biostratigraphic aspect is a particularly intriguing one. The epistominids with the genera Epistomina, Garantella, and Reinholdella, some of the (shallow marine) lituolid larger foraminifers, Middle Jurassic planktonic "globigerina" spp., several conspicuous nodosariids and Involutina provide a broad, relatively simple subdivision of the Jurrasic approximate to the stage level.

This biostratigraphic framework which is being developed in the Grand Banks Shelf area (Gradstein et al., 1975; Jansa et al., 1976; Gradstein, in press), where thick fossiliferous Lower, Middle, and Upper Jurassic sediments 
have been found relies heavily on previous studies in the tethyan belt and adjacent region in the boreal realm. Assuming suitable facies (shallow to open marine, ?bathyal and preferably shales and marls) the Grand Banks Jurassic biozonation should be appreciable to the U.S. continental margin. Preliminary data indicate the Jurassic zonation can be extended to the Scotian Shelf, immediately southwest of the Grand Banks (P. Ascoli, personal communication).

Some of the Lower-Middle Jurassic Grand Banks marker species (nodosariids, epistominids, "Globigerina" spp.) might occur in deeper the internal partitions in the chambers are more or less in the plane of coiling which is a characteristic of Epistomina (cf. Pazdro, 1969, p. 19).

Luterbacher (1972) reported specimens of Dorothia (Marsonella) doneziana, Epistomina uhligi (cf. Brotzenia sp. aff. B. uhligi and Brotzenia sp. ex. gr. $B$. parastelligera; see Ohm, 1967, for synonymies), and Lenticulina quenstedti (cf. L. ex. gr. quenstedti) in Upper Jurassic (Oxfordian to Kimmeridgian/Tithonian) beds in DSDP Leg 11, Sites 100 and 105.

\section{Methods}

We recovered fifty-four cores from Hole 391C. Washed residues were studied from about 90 samples, and thin sections were studied from 3 samples. Only about 30 washed residues and one thin section yielded foraminifers. We found age-diagnostic taxa in 11 washed residues (1-CC; 2-CC; 5-CC; 11-3, 45-47 cm; 14-3, 66-68 cm; 24-3, 14-16 $\mathrm{cm} ; 26-3,60-62 \mathrm{~cm} ; 50-1,52-54 \mathrm{~cm} ; 52-2,56-58 \mathrm{~cm} ; 52-3$, 9-11 cm; and 52-4, 100-102 cm). Compared to Sites 105 and 367 (DSDP Legs 11 and 41, respectively) which penetrated a very similar section; the Jurassic-Cretaceous fauna at Site 391 is sparse.

\section{Pleistocene (hemipelagic mud and oozes)}

Core 391C-1 taken at 335.5-345 meters depth yielded a rich foraminifer fauna. All specimens are from the less than $125 \mu \mathrm{m}$ fraction, suggesting that they were deposited in a distal current or gravity flow. The age of the fauna is probably Pleistocene with commonly occurring Globorotalia scitula, Globigerina calida, G. quinqueloba, G. pachyderma, Globigerinoides ruber, G. trilobus, Orbulina universa, and $O$. bilobata.

Poorly preserved Globorotalia cf. kugleri and $G$. aff. plesiotumida may be reworked from Miocene rocks. Small benthic forms, some reworked from a shallow marine environment, are: Elphidium, Cibicides lobatulus, Bolivina, Eponides, Anomalina, Sphaeroidina, Cassidulina, and Pyrgo.

From the section drilled in the adjacent Hole 391A, we know Miocene rocks occur between 149 and 649 meters. Consequently, we conclude that the Pleistocene sediments recovered in Core 391C-1 from 340 meters contain sediments displaced down-hole from above 149 meters.

\section{Miocene (carbonaceous silt; mudstone and intraclastic chalks, unit 2)}

Hole 391A extensively cored in Miocene sediments at this site. Sample 391C-2, CC between 611-620.5 meters is from the only Miocene sediment cored in 391C. The (?sorted) fauna, composed only of tiny specimens includes
Globorotalia kugleri, G. siakensis, and Globoquadrina dehiscens, might be from zones N.5-N.6.

Such a stratigraphic position fits in the lower Miocene stratigraphic succession established in Hole 391A (Figure 20) on the basis of nannofossils and radiolarians. The ?N.4 Zone assemblage in Sample 391A-19, CC at about 580 meters may well be reworked.

\section{Albian-Upper Cretaceous? (dark green-black claystone; 3 variegated claystone beds; unit 3; Cores 391C-3-13, 391A-21; 649-1001m}

Samples from Cores 391C-3, 4, and 391A-21 contain no foraminifers. We recovered an exclusive assemblage composed of tiny siliceous arenaceous specimens in Samples 5, Cc and to a lesser degree in Samples 6, CC; 8, CC; 9 , CC; and 10-2, 105-107 cm; 10-3, 57-59 cm; between 677.5 and \pm 900 meters. The fauna comprises Uvigerammina, Bolivinopsis, Plectorecurvoides (many and well preserved), Ammodiscus, Glomospira, Hormosina, Bathysiphon, Glomospirella, Reophax, ?Texturalaria, Trochammina globigeriniformis, Trochammina sp., Recurvoides sp., and Ammobaculites.

Serpulids are present in Sample 6, CC. In Sample 9-2, $48-50 \mathrm{~cm}$, poorly preserved tiny planktonic foraminifers including Hedbergella and in 10-2, 73-74 cm, Patellina spp., Spirillina, andsponge spicules occur; tiny, well-preserved Globigerina and radiolarians in 5, CC and some deeper samples are considered cavings; 6-2, 113-115 $\mathrm{cm}$; 6-4, 52-54 cm; 9-1, 33-35 cm; and 10-CC are barren. The best preserved and most diversified arenaceous fauna is in vareigated claystone beds (e.g. Sample 5, CC).

The arenaceous fauna may well be characeristic of the variegated clays. It has been found in similar clays at Site 367, Leg 41 (eastern North Atlantic) and at Site 386, Leg 43, (northwestern Atlantic). Krashenninikov (1973) found a more or less similar fauna in variegated clays in the Pacific Ocean during Leg 20. He believes this to be an Upper Cretaceous abyssal fauna which lived below the CCD. The clays from Legs 41 and 43 are tentatively dated as Upper Cretaceous to Paleocene(?). A section of variegated clays at Site 136, Leg 14, was identified as upper Aptian by Beckman and Roth.

On the basis of the presence of Uvigerammina, Bolivinopsis, and Plectorecurvoides, we tentatively date Sample 391-5, CC, to 391-8, CC as Albian-Upper Cretaceous (see Loeblich and Tappan, 1964); Hedbergella in Sample 9, CC is Cretaceous. Following Krashenninikov, the fauna may be from an abyssal depth as evidenced by the isolated, poorly preserved calcareous tests.

Tiny specimens in Sample 11-3, 45-47 $\mathrm{cm}$ of Hedbergella trocoidea, H. spp., Globigerinelloides aff. ferreolensis, and Gavelinella aff. intermedia may be upper Aptian-lower Albian forms.

\section{Lower Cretaceous (light colored limestone; unit 4, Cores 14-45; $1001-1324 \mathrm{~m}$ )}

Rarely occurring and etched specimens of Hedbergella sigali, Gavelinella barremiana, and Lenticulina crepidularis in Sample 14-3, 66-68 cm correlate to the lower part of the Hedbergella sigali Zone (LC8; van Hinte, $1976 \mathrm{a}, \mathrm{b})$ and the informal benthic foraminifer zone of 
Gavelinella barremiana-Lenticulina (M.) sigali as recognized at Sites 390 and 392, Blake Nose. Both are Barremian zones.

Ammonite aptychi occur as high as Sample 14, CC. At Site 105, DSDP Leg 11, the youngest aptychi fauna was of Hauterivian/upper Valanginian, which might also be true of the aptychi from Sample 14, CC.

A thin section in Core 15 revealed some Epistomina, Lenticulina, miliolids, echinoid, crinoid, and ?coral fragments which may in part have been displaced from a shallow marine environment.Samples $21, \mathrm{CC}$ and $22, \mathrm{CC}$ have Dorothia sp. (not D. praehauteriviana) and Pseudonodosaria sp.

Samples 24-3, 14-16 cm; 26-3, 60-62 cm; and 26-4, $30-32 \mathrm{~cm}$ are dated as Valanginian on the basis of the overlap in ranges of small, rare specimens of Conorboides hofkeri, Lenticulina nodosa, and many large specimens of Dorothia praehauteriviana (see Bartenstein, 1976). Also present are Eoguttulina sp., Vaginulopsis sp., Glomospirella, Glomospira sp., Lenticulina sp., Haplophragmoides sp., and radiolarians. The presence of Dorothia praehauteriviana (cf. Marsonellikummi by Bartenstein, 1976) correlates these samples to Leg 11, Site 101A, Cores 10 and 105 and Cores 19-21 which Luterbacher (1972), tentatively dated as Valanginian (cf. Dieni and Massari, 1966). Washed residues of Samples 24-5, 110-112 cm; 25-1, $49-51 \mathrm{~cm} ; 25-2,105-107 \mathrm{~cm} ; 26-1$ $100-102 \mathrm{~cm}$; and $26-2,100 \mathrm{~cm}$ only contain many well-preserved calcified and pyritized radiolarians.

Cores 27 through 50, contain no foraminifers except for isolated specimens of Glomospira, Spirillina, Vaginulopsis, or Ophthalmidium and some arenaceous forms in Samples $28-2$, $45-47 \mathrm{~cm} ; 28$, CC; $35-4,72-73 \mathrm{~cm} ; 36$, CC; $42-4$, $130-132 \mathrm{~cm} ; 42, \mathrm{CC} ; 46, \mathrm{CC} ; 50-1,145-147 \mathrm{~cm}$; and $51-2$, $40-42 \mathrm{~cm}$. No foraminifers were found in Samples 27-3, $15-17 \mathrm{~cm} ; 27-3,97-99 \mathrm{~cm} ; 28-3,56-59 \mathrm{~cm} ; 29-2,26-28 \mathrm{~cm}$; $29-5$, 56-58 cm; 29, CC; 30-2, 6-8 cm; 30-3, 44-46 cm; $31-3,40-42 \mathrm{~cm} ; 31-3,107-109 \mathrm{~cm} ; 31-5,106-108 \mathrm{~cm}$; $32-3$, 30-32 cm; 34-4, $115-117 \mathrm{~cm} ; 35$, CC; 36-5, 48-49 $\mathrm{cm} ; 37-2,72-73 \mathrm{~cm} ; 40-2,59-61 \mathrm{~cm} ; 41-2,79-81 \mathrm{~cm} ; 45-2$, $80-82 \mathrm{~cm} ; 45-3,60-62 \mathrm{~cm}$; and $52, \mathrm{CC}$. Radiolarians are common in some.

\section{Jurassic Red Limestone (unit 5; Cores 45-54; 1324-1412)}

Foraminifers in Samples 50-1, 52-54 cm; 51, CC; 52-2, $56-58 \mathrm{~cm}$; and $52-4,100-102 \mathrm{~cm}$ include Lenticulina quenstedti, Epistomina uhligi, and Dorothia doneziana which correlate to the Epistomina mosquensis Oxfordian-Kimmeridgian Zone on the Grand Banks of Newfoundland (Gradstein, in press). Specimens are etched, in part, and are rare to common in the samples. Specimens of the genera Lingulina, Ammobaculites, Ophthalmidium, Ammodiscus, Vaginulopsis, and Glomospirella are rare.

The dental apertures in some specimens of Epistomina uhligi are less latero-marginal than in $E$. uhligi as known from the Grand Banks of Newfoundland and are superficially similar to Reinholdella. However, the internal partitions in the chambers are more or less in the plane of coiling which is a characteristic of Epistomina (cf. Pazdro, 1969 , p. 19).

Luterbacher (1972) reported specimens of Dorothia (Marsonella) doneziana, Epistomina uhligi (cf. Brotzenia sp. aff. B. uhligi and Brotzenia sp. ex. gr. B. parastelligera; see Ohm, 1967, for synonymies), and Lenticulina quenstedti (cf. L. ex. gr. quenstedti) in Upper Jurassic (Oxfordian to Kimmeridgian/Tithonian) beds in DSDP Leg 11, Sites 100 and 105.

\section{Hole 391C}

\section{Cretaceous-Upper Jurassic}

Below the barren interval of Cores 391C-4 through -8, the first carbonate-bearing layers are encountered intermittently in Cores 391C-9 and 10, in lighter colored grayish claystone. A flora of well preserved, but etched nannofossils found in these layers probably indicates their deposition just above the CCD for nannoplankton. Samples in Cores 9 and 10 from the lower part of sub-unit $3 \mathrm{a}$ are assigned to the upper Aptian to lower Albian Parhabdolithus angustus Zone and to the Chiastozygus litterarius/Parhabdolithus angustus zonal interval, respectively. In samples from the claystone of sub-unit $3 \mathrm{~b}$ (Cores 391C-11 through -13), the nannofossils are strongly etched so that critical index species are sometimes difficult to recognize. Samples in Cores 391C-11 and -12 are referred to the upper Barremian to lower Aptian Micrantholithus hoschulzi/Chiastozygus litterarius zonal interval. Sample 391C-13, CC contains the highest reported occurrence of Calcicalathina oblongata of the underlying Calcicalathina oblongata/lithraphidites bollii zonal interval.

Unit 4 (represented in Cores 391C-14 through -45) consists of limestone with varying numbers of shale or mudstone interbeds. Moderately well to poorly preserved nannofossils occur in the shaly layers. Samples from Cores $391 \mathrm{C}-13$ through -32 are assigned to the combined Calcicalathina oblongata/Lithraphidites bollii zonal interval (upper Valanginian-lower Barremian) on the basis of the total range of Calcicalathina oblongata. Lithraphidites bollii was found in a sample from Core $391 \mathrm{C}-16$ and questionably in samples from Cores 391C-15, -17 , and -21 ; however, this restricted index species occurs too sporadically to recognize a separate Lithraphidites bollii Zone (upper Hauterivian-lower Barremian) with certainty. The co-occurrence of Tubodiscus verenae and Calcicalathina oblongata from samples from Cores 391-25 to -31 indicates the presence of the Calcicalathina oblongata Zone (upper Valanginian-lower Hauterivian), at least in the lower part of the interval.

Samples from Cores $391 \mathrm{C}-33$ to -37 are assigned to the upper Berriasian to lower Valanginian Cretarhabdus crenulatus zone. This zone is defined by the appearance of the zonal marker prior to the appearance of Calcicalathina oblongata. Nannoconus colomii first occurs in Core 391C-45. Cores 391C-34 to -45 are assigned to the upper Tithonian to Berriasian Nannoconus colomii Zone. Nannofossils from the very thin shale partings in this interval are poorly preserved because of calcite overgrowths.

Nannofossils in the reddish marls of unit 5 are moderately well preserved, in contrast to those of unit 4. Cores 491C-46 to -54 are assigned to the Parhabdolithus embergeri Zone, defined by the appearance of the index species prior to the appearance of nannoconids. The Parhabdolithus embergeri zone is either lower Tithonian or a upper Kimmeridgian. 


\section{Radiolarians}

Neogene radiolarians are present in varying abundance and preservation in the upper 20 cores of Hole 391A Figure 22. The lower part of the section (Hole 391C) contained virtually no radiolarians. A single sample of Pleistocene sediment yielded a diverse assemblage of well-preserved radiolarians in which the most characteristic constituents are Amphirhopalum ypsilon (three or four chambers before the bifurcation), Euchitonia mulleri, Ommatartus tetrathalamus, Polysolenia murrayana, P. spinosa, Tetrapyle octacantha, Heliodiscus asteriscus, Druppatractus aquilonius, Lamprocyclas maritalis, Lithopera bacca, Eucrytidium tumidulum, E. acuminatum, Anthocyrtidium ophirense, and Dictyophimus crisae. The nature of the assemblage suggests it falls within the Amphirhopalum ypsilon Zone, which dates the sample as lower Pleistocene. The presence of Stichocorys peregrina, $S$. delmontense, Cyrtocapsella tetrapera, C. isopera, Thyrosocyrtis rhizodon, and Theocampe mongolfieri provide evidence that the sample contains reworked Pliocene, Miocene, and Eocene sediments. Collosphaerids are abundant and well preserved in this sample.

The few meters of sediment immediately below this sample contain no siliceous microfossils. Siliceous microfossils are present again in sediments from the base of 391A Core 5, Section 6, and, except for one sample (11-2, $20 \mathrm{~cm}$ ) and one interval for which no samples were available (Cores 14 and 15), they occur throughout Cores 5 through 20.

Cores $5,6,9,10,11$, and 12 consist of displaced intraclastic carbonate ooze and chalk, the majority of which appears to have been displaced by debris flows and slumping from the Blake Plateau region. Many of the clasts contained within these cores are rich in siliceous microfossils. They were sampled and analyzed in an attempt to date the number of separate depositional events responsible for this large amount of carbonate deposition throughout the Blake-Bahama Basin. Radiolarian age assignments for these cores are thus the ages of the displaced siliceous clasts. Only those sediments from Core 7 and the upper part of Core 8, Section 1 represent undisturbed normal pelagic deposition.

The Dorcadospyris alata Zone comprise the interval from the bottom of Core 5 to approximately halfway down Core 7. Tentatively, the base of this zone is placed between Samples 391A, 7-4, 70-72 cm, and 7-5, 74-76 cm. A short section of the Calocycletta costata Zone is present in Samples 7-5, 74-76 cm and 8-1, 30-40 cm. The rest of Core 8 contains assemblages, characteristic of the Cyrtocapsella tetrapera Zone of the lowermost Miocene. Samples examined from Core 9, however, fall in the next two higher Zones (Stichocorys delmontensis and S. wolfi zones). Cores 10 through 13 again contain assemblages of the Calocycletta costata Zone. No samples were available from Cores 14 and 15 for which there was virtually no recovery. Since the top of Core 16 is placed in the Stichocorys delmontensis Zone and because it appears that the base of the Calocycletta costata Zone lies either at the bottom of Core 13 or just below it, we surmise that the Stichocorys wolffii Zone would be found in the unsampled interval of
Cores 14 and 15 . We could not properly ascertain the base of the Stichocorys delmontensis Zone. Although many radiolarians were found in Cores 17 through 19, they were generally poorly preserved making zone assignments difficult. A further problem is the presence of small numbers of reworked, predominantly middle Eocene radiolarians throughout most of the Miocene section. Detailed analyses of the radiolarians from this interval indicate that the base of the $C$. Tetrapera Zone could lie anywhere between Samples 17-3, 84-86 cm and 19-4, 34-37 $\mathrm{cm}$. The base of the Cyrtocapsella tetrapera Zone is tentatively placed between Samples 20-3, 84-86 cm and $20-4,83-85 \mathrm{~cm}$. The remainder of Core 20 is placed within the Lychnocanoma elongata Zone.

The radiolarian biostratigraphy of Hole 391A, Cores 8 and 9 , is especially interesting. Here several meters of older sediment are found on top of younger sediments. A reasonable explanation for this is that at the time the $C$. costata Zone sediments were being deposited several episodes of large downslope displacements occurred in the Blake-Bahama Basin. The first episode deposited older material of the $S$. delmontense Zone on top of the $C$. costata Zone. Later episodes resulted in the deposition of sequentially older material, exposed upslope on this sediment pile.

\section{SEDIMENT ACCUMULATION RATES}

For each lithologic unit and sub-unit of Site 391, a maximum rate of accumulation is estimated from the ages of the contained groups. The accumulation rates of the Upper Jurassic-Lower Cretaceous sediments were determined mainly on the basis of nannofossil data from Hole 391C. We calculated the accumulation rates during the Miocene and Quaternary of Hole 391A from a comparison of radiolarian, nannofossil, and foraminifer zonations to the time scale of Ryan et al. (1974). Table 15 shows all data for each lithologic unit used to derive the accumulation rate and the sediment accumulation curve (Figure 23). The average rates for some intervals recovered are fairly high for a deep marine realm: lower Tithonian-lower Berriasian, $2.4 \mathrm{~cm} / 1000 \mathrm{yr}$ and the lower-middle Miocene, 3.5-4.3 $\mathrm{cm} / 1000 \mathrm{yr}$.

A more detailed presentation of data is given for Miocene depositional events in Hole 391A (Figure 24). Because of the unusual texture and rapid deposition of the intraclastic chalk in lithologic sub-units $2 \mathrm{~b}$ and $2 \mathrm{~d}$, we have attempted to delineate paleontologically the minimum number of depositional events responsible for their accumulation in the Blake-Bahama Basin. Preliminary analyses indicate that sub-unit $2 \mathrm{~d}$ falls within the N.8 and N.10 foraminifer zones, and within the NN 5 nannofossil zone, while sub-unit $2 b$ lies within the N.12 and N.13 foraminifer zones. We estimate that sub-unit $2 \mathrm{~d}$ was deposited within 1 million years (15 to 16 m.y. B.P.; middle Miocene) and that $2 \mathrm{~b}$ accumulated within 1.25 million years (12.75 to $15 \mathrm{~m} . \mathrm{y}$. B.P.; middle Miocene).

No beds of pelagic or hemipelagic mudstone are present within sub-unit $2 \mathrm{~d}$; however, sub-unit $2 \mathrm{~b}$ contains autochthonous sediments which suggests that a number of depositional events were responsible for its accumulation. Clasts of both pelagic mudstone and hemipelagic mudstone 


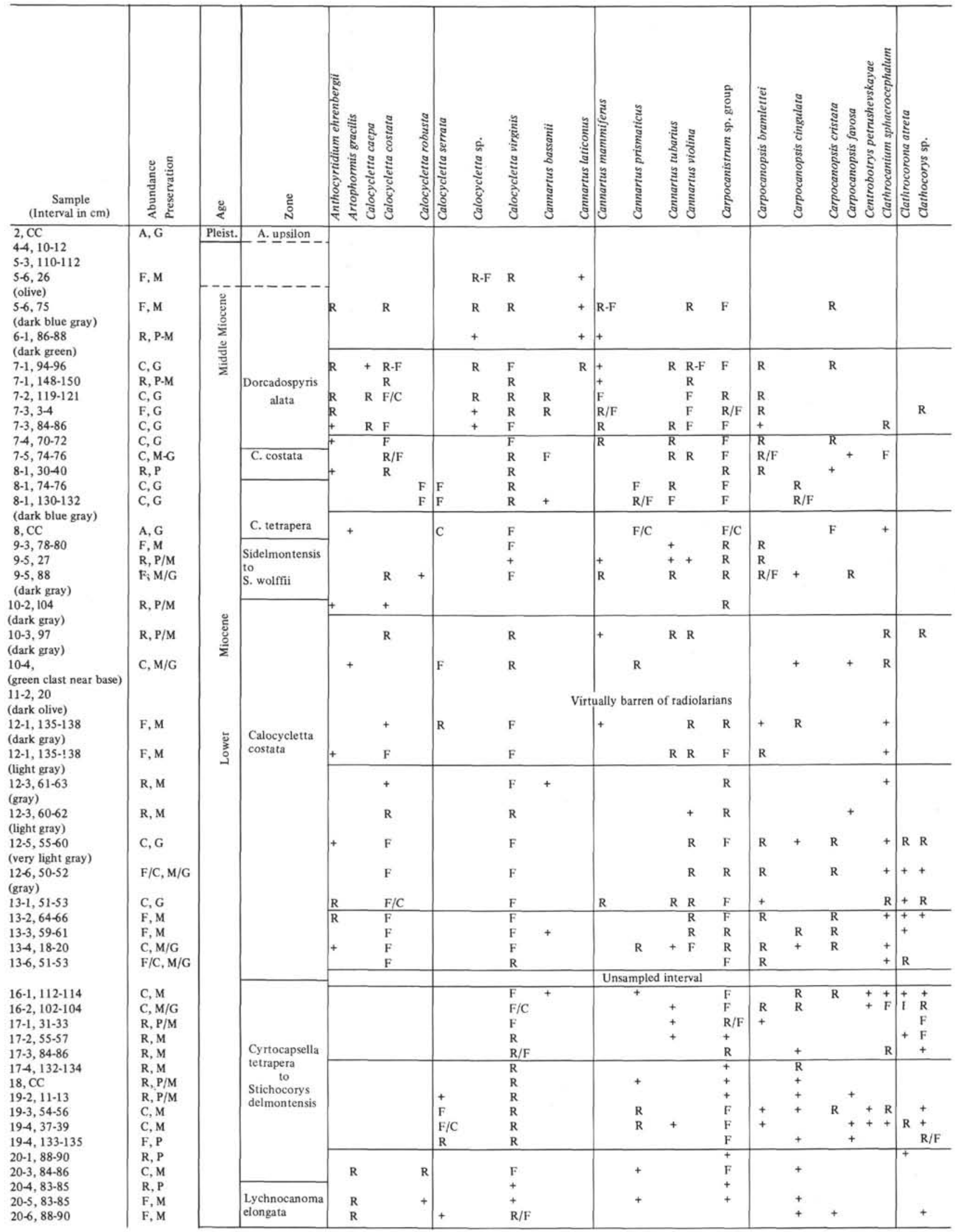

Note: Abundance; A - Abundant; C - Common; F - Few; R - Rare; + - Trace; Preservation; G - Good; M - Moderate; P - Poor.

Figure 22. Distribution of radiolarians, Hole $391 \mathrm{~A}$. 


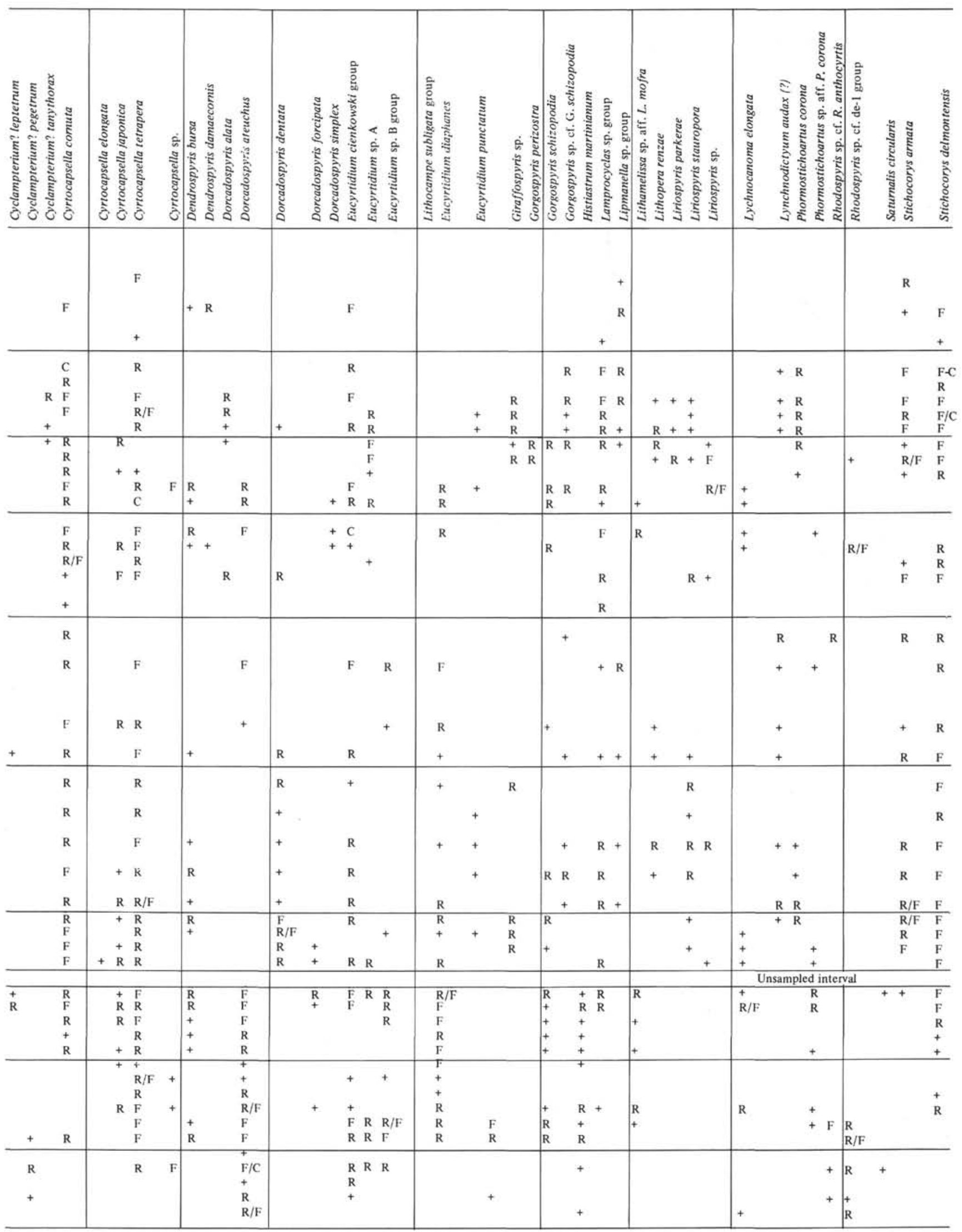

Figure 22. Continued. 


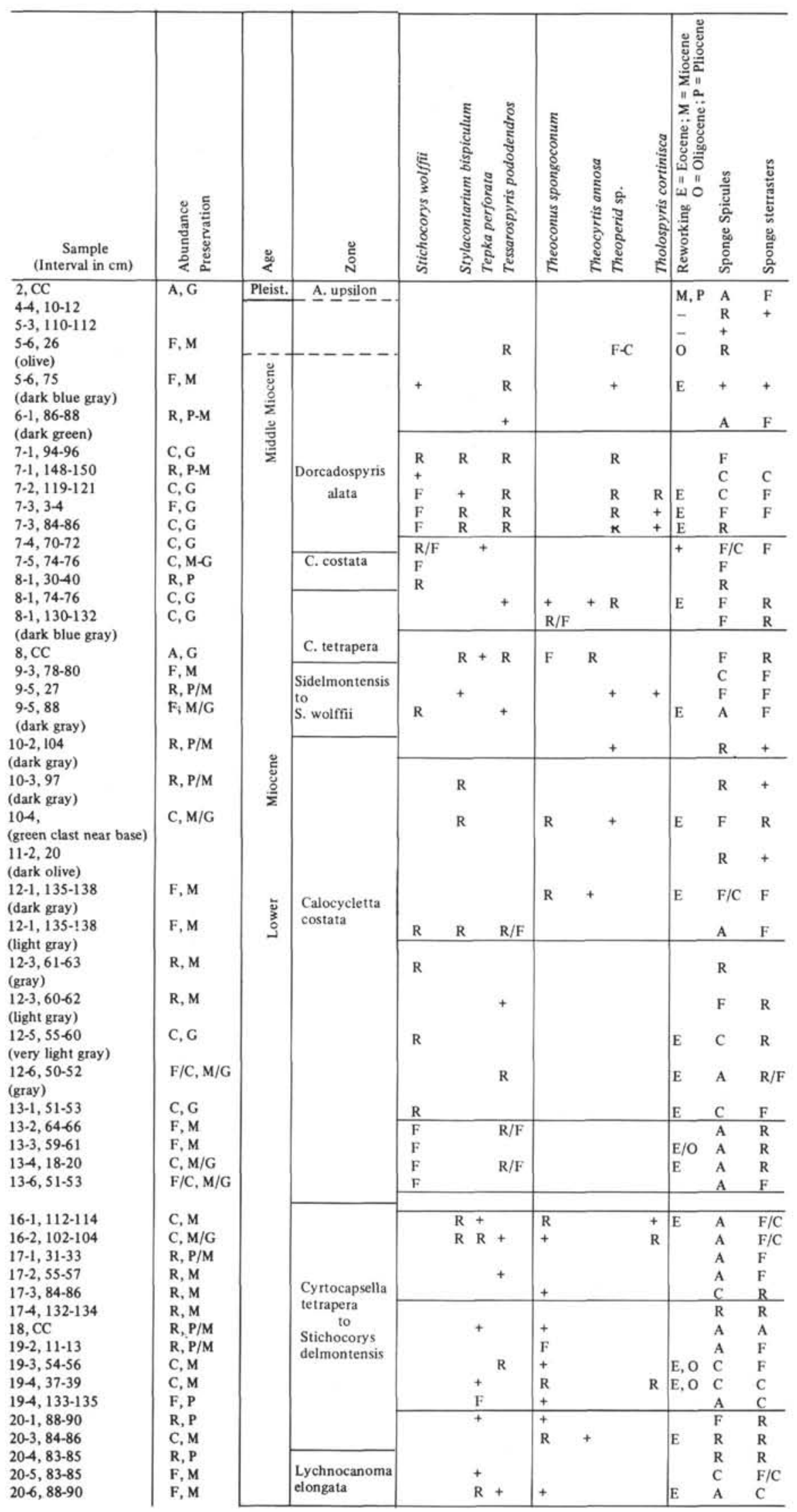

Note: Abundance; A - Abundant; C - Common; F - Few; R - Rare; + - Trace; Preservation; G - Good; M - Moderate; $\mathrm{P}$ - Poor.

Figure 22, Continued. 
were recovered within this sub-unit. Examination of the mudstone clasts in Core 5 indicates that they are slightly younger than the siliceous mudstone recovered in Cores 7 and 8 . This indicates that at least one pelagic depositional event took place within the Blake-Bahama Basin during the accumulation of sub-unit $2 \mathrm{~b}$. In addition, the intraclastic chalk deposition is interrupted in Core 4 , Section 4 by two small beds of barren hemipelagic mudstone which suggests that yet another depositional event interrupted chalk sedimentation between 12.75 and 15 m.y.B.P.

Paleontological data therefore suggest that the massive influx of over 240 meters of allochthonous chalks deposited within Cores 4 through 12 may have been deposited during a number of separate events.

\section{CORRELATION OF THE SEISMIC REFLECTION PROFILE WITH DRILLING RESULTS}

Site 391 was precisely located within one mile of the IFP/USGS multichannel seismic reflection profile, at FC II shot point 620 . The profile, processed with 24 -fold stacking and shot with a Flexichoc sound source, gives an excellent presentation of the reflection horizons down to and including oceanic basement (Dillon et al., 1976). Seven reflectors are identified at $0.21,0.32,0.59,0.97,1.14$, 1.32, and 1.44 sec sub-bottom (Figure 25). All but the last two were cored in Holes $391 \mathrm{~A}$ and $391 \mathrm{C}$.

The shallowest sub-bottom reflector, at $0.21 \mathrm{sec}$, is correlated with the contact between unconsolidated upper Miocene chalk and ooze (of lithologic sub-unit 2a) and the underlying and more consolidated middle Miocene intraclastic chalk-breccia (sub-unit $2 b$ ). On the basis of this correlation the compressional wave velocity for the upper Miocene to Quaternary chalk and clay is calculated as 1.93 $\mathrm{km} / \mathrm{sec}$, which is higher than the $1.49-1.88 \mathrm{~km} / \mathrm{sec}$ range of velocities measured on the core samples from this interval (see Physical Properties), but not unreasonably so.

Note that this reflector can be traced from Site 391 to the base of the Blake Escarpment where it has been exposed probably by deep bottom currents. The reflector had been previously sampled at the base of the escarpment with piston cores and identified as a lower upper Miocene carbonate turbidite beneath Pliocene-Pleistocene clay and ooze (Sheridan et al., 1974). Although slightly older at Site
391, (middle Miocene), the turbiditic nature of this reflector apparently persists over the general region of the Blake-Bahama Basin.

The second deeper reflector at $0.32 \mathrm{sec}$ sub-bottom is correlated with the upper contact of the hard lower Miocene intraclastic chalk breccia of sub-unit $2 \mathrm{~d}$. Such a correlation gives a calculated velocity of $2.58 \mathrm{~km} / \mathrm{sec}$ for the overlying middle Miocene intraclastic chalk breccia which is reasonable for these fairly well consolidated rocks. The measured sonic velocities on the cores for this interval are generally lower, at $1.66-2.24 \mathrm{~km} / \mathrm{sec}$.

The next deeper reflector, at $0.59 \mathrm{sec}$, is horizon $A$ (Markl et al., 1970). It is correlated with the marked unconformity between the Miocene intraclastic chalk and claystone and the Upper Cretaceous variegated and black clays. The hard chalk was cored directly over the contact; oxidized, orange, and fissile variegated claystones lie immediately below. Apparently erosion had exposed some variegated and black claystones enough to oxidize their upper 2 or 3 meters.

This correlation gives a velocity of $2.25 \mathrm{~km} / \mathrm{sec}$ for the lower Miocene chalks, in reasonable agreement with the laboratory measured velocities of $1.62-2.36 \mathrm{~km} / \mathrm{sec}$. The correlation of the horizon $\beta$ reflector, at $0.97 \mathrm{sec}$ sub-bottom, with the base of the Albian-Aptian black to gray carbonaceous clay and claystone gives a calculated velocity of only $1.97 \mathrm{~km} / \mathrm{sec}$ for the Middle to Upper Cretaceous section (a velocity which agrees well with the $1.84-2.31 \mathrm{~km} / \mathrm{sec}$ range of laboratory measurements perpendicular to bedding). The velocity inversion of higher velocity chalks above lower velocity shales produces the high amplitude of reflector $A$.

Understanding the acoustic character of the sediments above and below horizon $A$ is of particular importance in this area. Previous seismic reflection surveys have used the small volume airguns commonly available to oceanographic institutions and have failed to penetrate horizon $A$. The reason is now apparent. The hard Miocene chalk reflects most of the sound energy when contrasted with the thin overlying soft sediments and the deep-water column. Whatever energy remains is then damped out by absorption in the soft fissil Cretaceous clay. Some of the soft clay expanded in the core liners as if gas were present, which

TABLE 15

Rate of Sediment Accumulation at Site 391 From Late Jurassic to Quaternary (The Miocene dates are averages from Hole 391A; the Cretaceous-Jurassic dates, from Hole 391C)

\begin{tabular}{|c|c|c|c|c|}
\hline Interval (m) & Lithologic Unit & Age & $\begin{array}{c}\text { Time Interval } \\
\left(10^{6} \mathrm{y}\right)\end{array}$ & $\begin{array}{c}\text { Sediment } \\
\text { Accumulation } \\
\text { Rate }\left(\mathrm{cm} / 10^{3} \mathrm{y}\right)\end{array}$ \\
\hline $0-147$ & 1 & Quaternary & 1.8 & 9.0 \\
\hline 147- 207 & 2 & Late Miocene & 6.5 & 0.9 \\
\hline $207-400$ & 2 & Middle Miocene & 4.5 & 4.3 \\
\hline $400-649$ & 2 & Early Miocene & 6.5 & 3.9 \\
\hline $649-1001$ & $3 a, 3 b$ & $\begin{array}{l}\text { Late Barremian- } \\
\text { Albian }\end{array}$ & 18.0 & 2.0 \\
\hline $1001-1220$ & $4 a, 4 b$ & $\begin{array}{l}\text { Late Valanginian- } \\
\text { Barremian }\end{array}$ & 10.5 & 2.1 \\
\hline $1220-1340$ & $4 c, 4 d$ & $\begin{array}{l}\text { Late Tithonian- } \\
\text { Early Valanginian }\end{array}$ & 8.0 & 1.5 \\
\hline $1340-1412$ TD & 5 & $\begin{array}{l}\text { Early Tithonian } \\
\text { (= late Kimmeridg.) }\end{array}$ & 3.0 & 2.4 \\
\hline
\end{tabular}




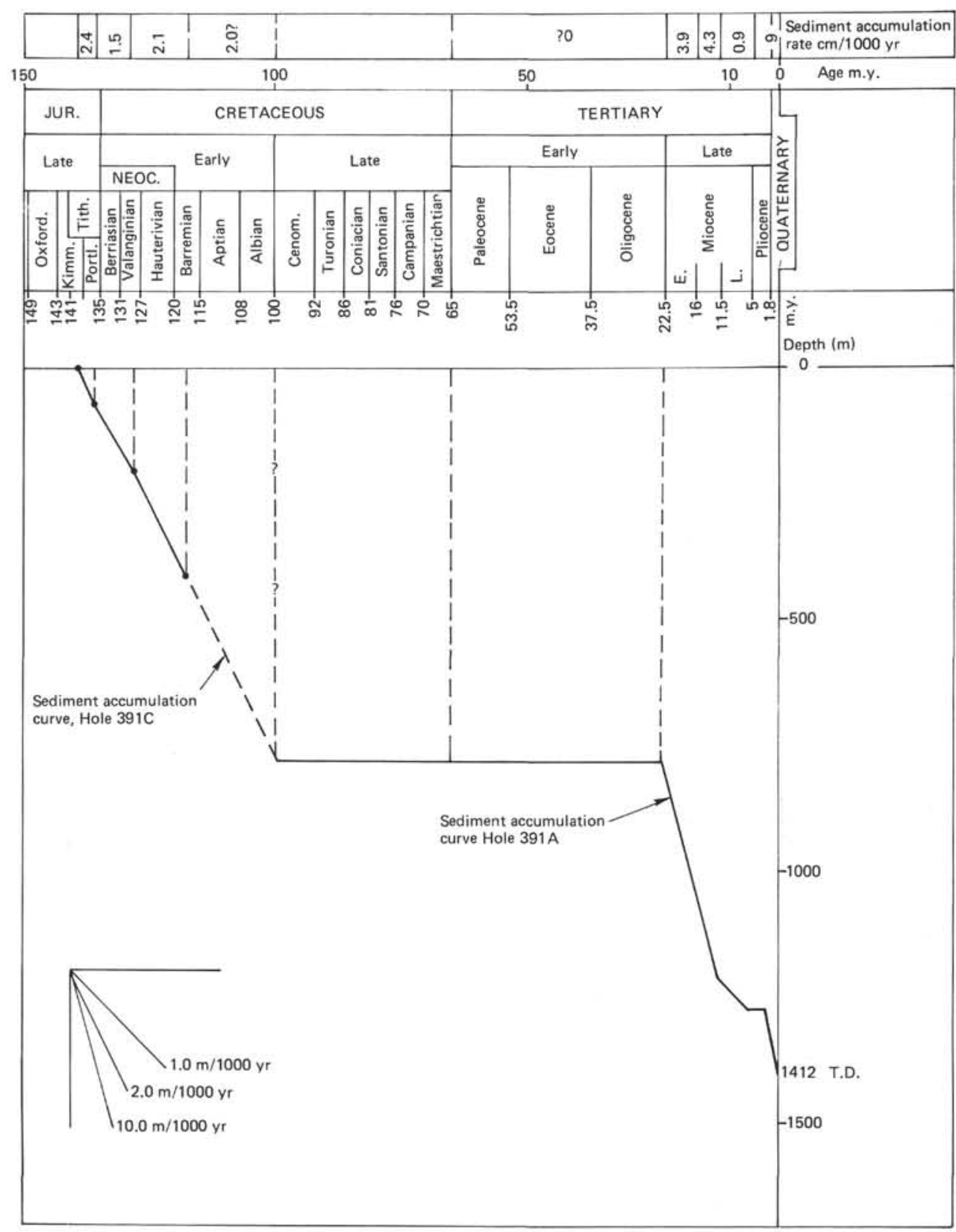

Figure 23. Rate of sediment accumulation from Late Jurassic to Quaternary, Site 391.

may have contributed to the absorption. This combined effect of reflection and absorption prevented detection of the deeper reflectors until greater energy sources were used.

The deepest reflector penetrated at Site 391 is at $1.14 \mathrm{sec}$ sub-bottom. This reflector, named reflector C, is correlated with the top of unit 5, or the interface between the upper Tithonian white and gray limestone and the lower Tithonain red limestone and shale. The physical change between overlying massive limestone and interbedded shale and limestone and softer shale is significant and is the horizon most likely to cause the reflection. This correlation of reflector C results in a calculated velocity of $3.65 \mathrm{~km} / \mathrm{sec}$ for the unit 4 , white and gray thoroughly recrystallized limestones. Laboratory measurements of velocity of these rocks are in agreement with this relatively high value, and with a general range of $2.02-4.05 \mathrm{~km} / \mathrm{sec}$ and some very high values of $4.53-5.43 \mathrm{~km} / \mathrm{sec}$ along particularly hard layers.

Note that the velocity calculation of $3.65 \mathrm{~km} / \mathrm{sec}$ is similar to the $3.64 \mathrm{~km} / \mathrm{sec}$ velocity reported for this depth in the Blake-Bahama Basin by Sheridan et al. (1966). Thus the relatively hard limestone unit beneath horizon $\beta$ apparently extends throughout the basin. The two reflectors bounding this limestone layer, i.e., horizon $\beta$ at the top and horizon $C$ at the bottom, can now be traced on the multichannel IFP/USGS profiles over a wide area (Dillon et al., 1976). Indeed the depth to these reflectors, and their acoustic character has led Dillon et al. (1976) to suggest correlations of horizon $\beta$ with the top of Neocomian limestone and horizon $C$ with top of Upper Jurassic limestone even though no other seismic profiles had tied these reflectors eastward where horizon $\beta$ and hori- 


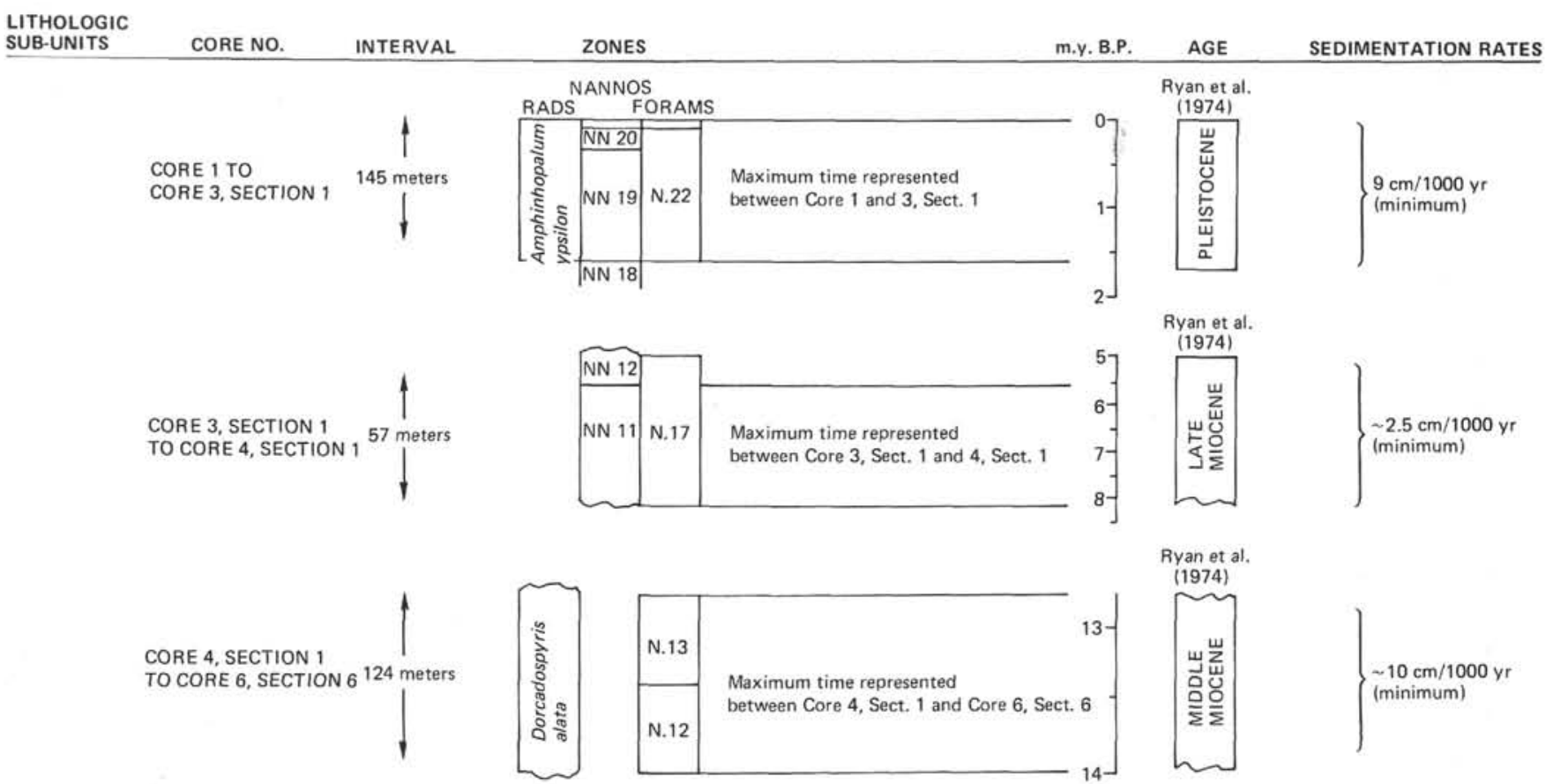

CORES 7 and $8=86$ meters of MIDDLE MIOCENE RADIOLARIAN MUDSTONE
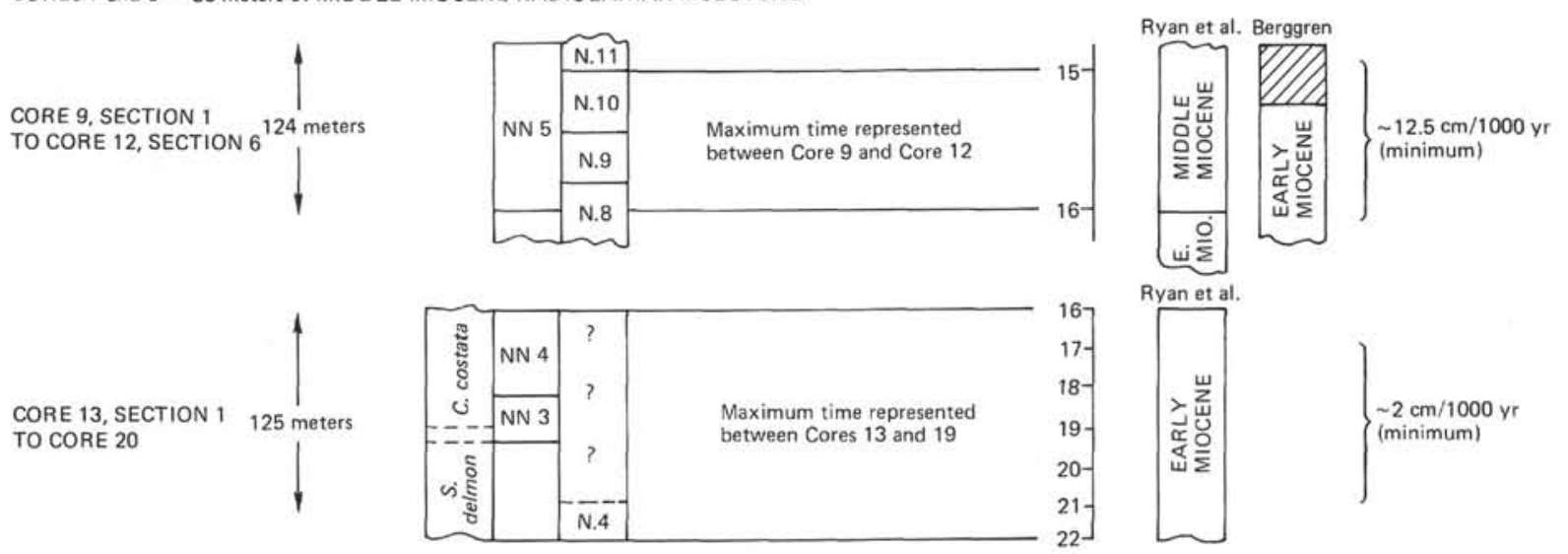

Figure 24. Summary of depositional events related to absolute time.

zon C were present on single-channel profiles, and where they were known to be of these ages. As seen in Figure 25, this seismic identification by Dillon et al. (1976) was substantiated by drilling at Site 391 .

Below the Tithonian limestone reflector $\mathrm{C}$ is a reflector at $1.32 \mathrm{sec}$ sub-bottom that was not reached in Hole 391C. Velocity measurements on the cored Tithonian red limestone and shale range from $2.32-3.50 \mathrm{~km} / \mathrm{sec}$ (excluding some hard layers of $4.57-5.12 \mathrm{~km} / \mathrm{sec}$ ). These velocities are compatible with sonobuoy velocities of 2.81 $\mathrm{km} / \mathrm{sec}$ determined for sediments just above basement in the area of Site 391 (John Ewing, personal communication). Using $2.81 \mathrm{~km} / \mathrm{sec}$ as a velocity for the Tithonian and older sediments, the depth to this $1.32 \mathrm{sec}$ reflector is 1583 meters; the depth to the basement $(1.44 \mathrm{sec})$ is 1752 meters. Near the site, however, the basement reflector rises to 1.35 sec sub-bottom, or at 1625 meters - an even shallower target for future drilling.

\section{SUMMARY AND CONCLUSIONS}

\section{Introduction}

The Blake-Bahama Basin, the westernmost abyssal area in the North Atlantic Ocean, is in the western part of the "magnetic quiet zone" and contains some of the oldest sediments in the Atlantic. DSDP Leg 11 sampled Oxfordian (lower Upper Jurassic) and possibly Callovian (uppermost Middle Jurassic) sediments overlying basement highs on the northwest and southeast margins of the basin. Recently available IFP-USGS seismic data and projection of magnetic anomaly spreading rates suggested that Lower Jurassic sediments possibly as old as Bathonian might be found in the Blake-Bahama Basin.

Drilling in the Blake-Bahama Basin became feasible in 1974 when the IFP/USGS multichannel CDP survey showed that basement was within reach of Challenger's drill string (1600 m to $1900 \mathrm{~m}$ sub-bottom), Dillon et al., 


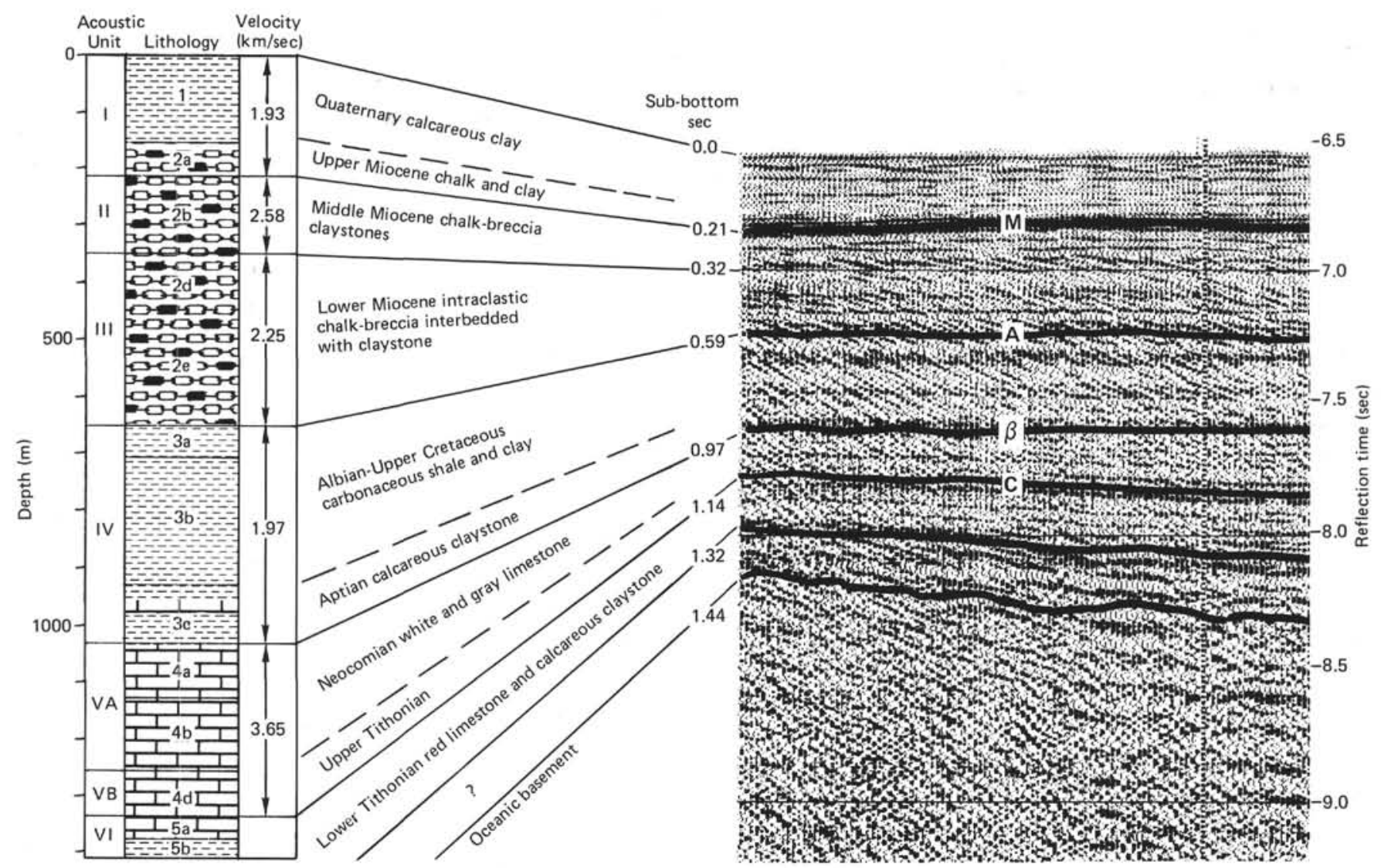

Figure 25. Correlation of lithology with seismic reflection profile MC 1 across Blake-Bahama Basin west of Site 391. Velocities are calculated based on correlations and drilling depth.

1976), and re-entry was possible. Site 391 was thus located in the south-central part of the basin near IFS/USGS profiles FC 11, shot point 620 .

We drilled four holes at the site. Holes 391 and 391B were drilled to verify the depth to the sea floor and to plan the length of casing below the re-entry cone; Hole 391A was drilled in the re-entry cone to a depth of 659 meters. When a technical failure required that the pipe be pulled and re-entry could not be achieved, Hole $391 \mathrm{C}$ was drilled to the destruction of a single bit at a record-setting 1412 meters sub-bottom.

Because of these technical difficulties we were unabłe to complete two of our major objectives of Leg 44: (1) to study the Middle and possibly Lower Jurassic strata thought to exist in the Blake-Bahama Basin, and (2) to determine the age and character of the basement and thereby establish the age of some mid-Early Jurassic magnetic reversals and spreading rates. Fortunately, the deep penetration and judicious coring of the four holes permitted us to complete the other objectives: (1) to establish the nature of the major reflecting horizons, (2) to study the late Cenozoic sedimentation in the basin, especially the turbiditic deposition, and (3) to verify and sample the Cretaceous carbonaceous unit for organic geochemical and petroleum source bed analyses.

Sediments cored included Quaternary through the entire Upper Jurassic sequence. The Pliocene and entire Paleogene are missing. The top 147 meters are Quaternary gray-green hemipelagic mud. These directly overlie a remarkable sequence, 500 meters thick, of Miocene carbonate clastics-turbidites and thick intraclastic chalk breccias. Figure 26 (in back pocket) graphically summarizes drilling at Site 391.

\section{Miocene Turbidites and Gravity Flow Deposits in the Blake-Bahama Basin}

The great thickness of Miocene carbonate conglomerates and chalk breccias found in Hole 391A is intriguing. Between 147 and 649 meters sub-bottom the Miocene interval consists of gravity-flow deposits of three general types (1) carbonate turbidite sequences showing partial Bouma cycles, (2) chalk breccia with a fine-grained carbonate-debris matrix enclosing platy angular clasts of green and brown clay or siliceous ooze, and (3) very coarse-grained conglomerate with fine-grained carbonate matrix enclosing both angular siliceous mudstone clasts and well-rounded shallow-water limestone pebbles.

The chalk breccias and conglomerates are surprisingly homogeneous with little evidence of grading over the length of the entire cores $(9.5 \mathrm{~m})$. Most of the clasts are platy and oriented horizontally (Figure 27). The lack of grading and of basal contacts implies that the mud matrix was dense enough to prevent the clasts from settling to a basal grain-on-grain structure. Rather the entire sediment was deposited more or less en masse from a slurry with the position of the floating clasts "frozen in." Some of the individual slurries may well have beeh more than 9.5 meters thick. 


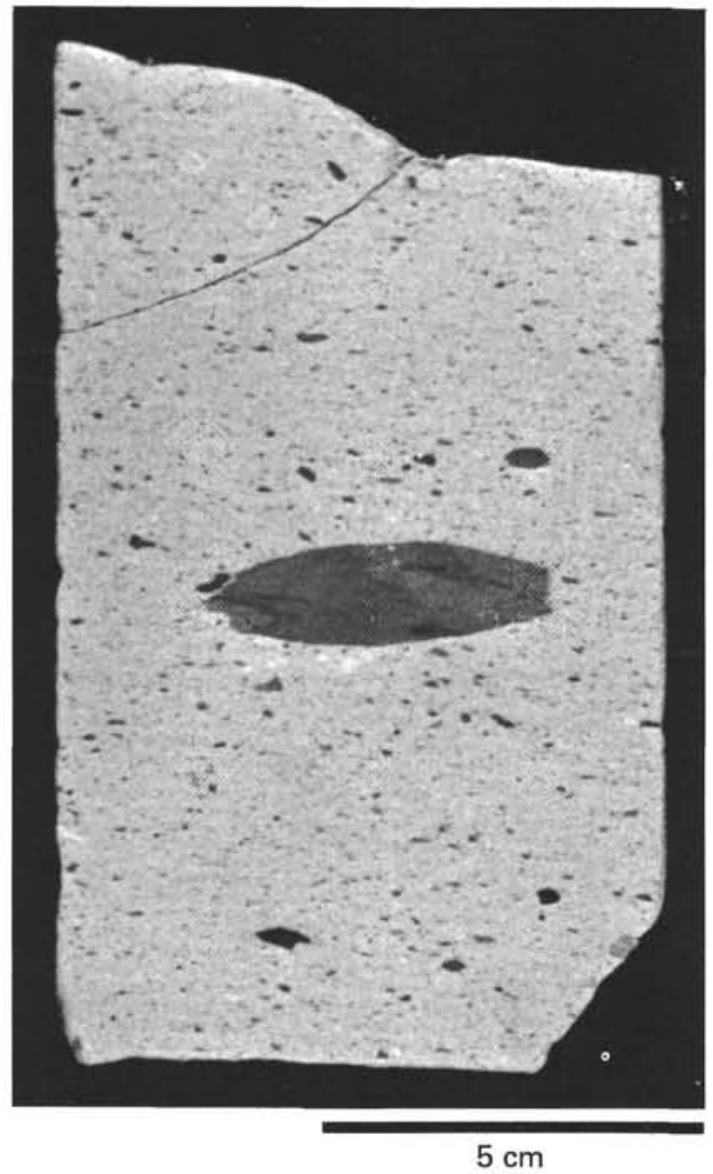

Figure 27. Typical greenish brown intraclast of radiolarian ooze in displaced nannofossil chalk matrix. Sample 391C-2-3, 122-132 cm.

These Miocene deposits accumulated in a remarkably short time. The entire 500 meters was probably deposited in less than 12 million years; individual parts accumulated more rapidly. For example, from 330 to 530 meters sub-bottom the lower Miocene chalk breccias were deposited within the time span of only two nannofossil zones, a maximum of only 2 million years, and a phenomenal sedimentation rate of more than $12 \mathrm{~cm} / 1000 \mathrm{yr}$. A thick interval of chalk breccia, as much as 66 meters (Core 9 to Core 11, Hole 391A), could possibly represent one depositional event.

The Miocene chalk breccias directly overlie the Cretaceous carbonaceous clay; the hiatus correlates with horizon $A$. But some of the incorporated clasts of penecontemporaneous clay and siliceous ooze must derive from a stratigraphically lower layer not present at Site 391 . Apparently, in addition to deposits eroded from further upslope ooze and clay that were deposited in the Blake-Bahama Basin below the CCD in early Miocene time either were eroded by bottom currents prior to deposition of the chalk breccias, or perhaps were stripped by the dense slurry of carbonate debris itself. The latter mechanism would imply a tremendous but not unreasonable erosive energy for the slurries.

Although some of the Miocene beds have features similar to deposits formed by dense turbidity currents - e.g., coarse, cross-bedded sands over a sharp basal contact, upward gradation to fine silt- and clay-size sediment with burrow mottling, and displaced shallow-water faunas (Sheridan et al., 1974) - the origin of the coarse chalk breccias and conglomerates with isolated, floating clasts, is less clear. The nearly horizontal orientation of most of the platy clasts suggests laminar hydraulic transport within the suspensate, which therefore must have been a slurry dense and viscuous enough to prevent settling of the clasts. Such a slurry would probably resemble a mud flow more than a typical turbidity current. This type of a massive gravity flow would satisfy many of the features observed: (1) the great thickness of single depositional units; (2) the lack of graded bedding; (3) the presence of convoluted bedding and internal slump features; and (4) the inferred large eroding and transporting capacity.

We are not certain of the source for such gravity flow deposits. Limestone clasts of an obvious shallow-water facies and certain genera of the displaced fauna such as Elphidium indicate a very shallow-water source, perhaps from water depths of 100 meters or less. The bulk of the displaced biota, however, are radiolarians and nannofossils similar to the assemblages found on the Blake Nose (Hole 390A). Sponge spicules are common also and indicate a slightly deeper water source, such as the Blake Plateau.

Thus these gravity flows and turbidites seem to have at least two sources, one very shallow and one of moderate depth (Figure 28). The very shallow source was probably the Bahama Banks which already existed in the Miocene and whose loose lagoonal sediments, stirred by an occasional hurricane, could easily have been washed down the many deep channels and canyons to the Blake-Bahama Basin. Such erosion would have been enhanced in the Miocene by possible sea-level fluctuations owing to (1) Antarctic glaciations (2) alternations of drying and filling the Mediterranean (Sheridan et al., 1974), or (3) local tectonic uplifts of Cuba (middle Miocene) which may also

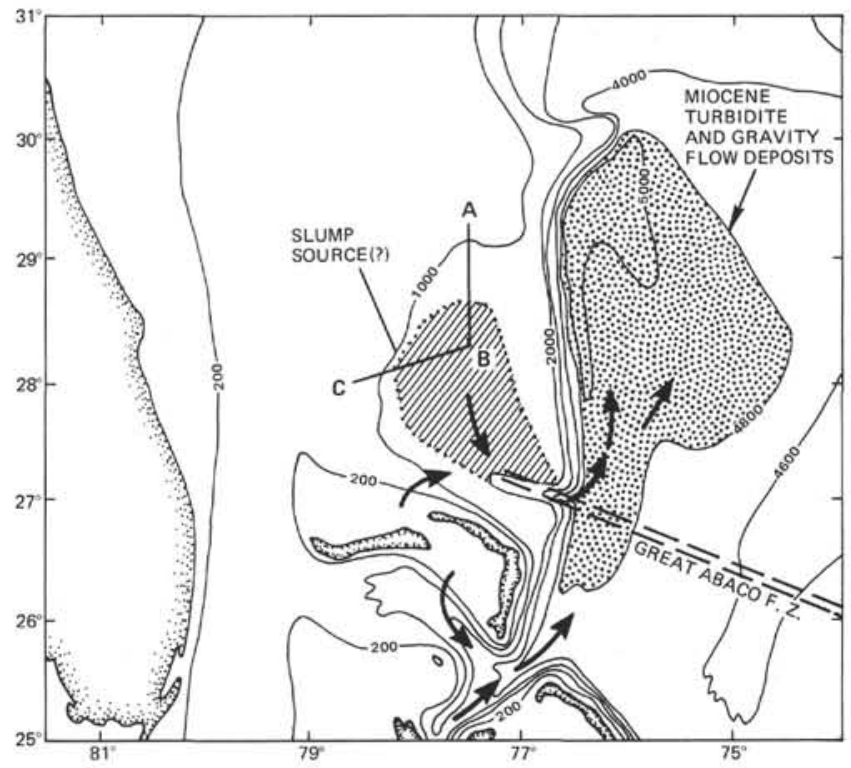

Figure 28. Possible sources for Miocene turbidites and gravity flow deposits in the Blake-Bahama Basin. 
have exposed the Bahama Banks (Goodell and Garman, 1969).

The deeper source may have been the Blake Plateau. The whole southeast quadrant of the plateau slopes eastward toward Great Abaco Canyon. Ewing et al. (1966) have shown that this canyon is an ancient feature and that the relief at the head of the canyon existed even before Miocene time. Their seismic profiles, controlled stratigraphically by JOIDES Hole J-3 (Schlee and Gerard, 1965), show that Miocene sediments have been cut away, exposing the Oligocene beds (Figure 29). Some of the beds are abruptly terminated to form impressive ledges suggesting external truncation. Conceivably the area near the head of the canyon could have contributed large amounts of debris from slumping masses of loosely consolidated carbonate oozes (Figure 28).

Great Abaco Canyon itself has been controlled by faulting that has affected at least Upper Cretaceous limestone deposition on the Blake Plateau (Sheridan et al., 1971). The Great Abaco fracture zone apparently extends from the Atlantic crust and impinges on the Blake Plateau along the canyon's axis. Earthquakes probably shook the area especially in the Miocene when tectonic activity in nearby Cuba created added stress along the fracture zone. The shocks could have distrubed the loosely consolidated oozes to the point of spontaneous liquefaction, causing abrupt avalanches of sediments down the canyon. Velocities of the flows would have increased as the canyon funneled the massive flows down to the ancient Miocene Blake-Bahama abyssal plain to strip off Miocene abyssal sediments and ultimately deposit the massive gravity flow sediments. These massive gravity flows and turbidity currents were unique to the Miocene and restricted to the Blake-Bahama Basin; they apparently did not occur in the rest of the western North Atlantic. Apparently, the ancient Miocene foundations of the Blake and Bahama Outer Ridges trapped these gravity flows in the Blake-Bahama Basin (Figure 30). The model just presented is admittedly speculative, but it does explain the observed features of these interesting deposits.

\section{Upper Cretaceous Sediments and Correlation of Major Seismic Reflection Horizons A, $\beta$, and C}

The Miocene breccias lie unconformably on dark green to black carbonaceous clay that elsewhere in the western North Atlantic have been identified as mid-Cretaceous deposits. At Site 391 the upper black clay is unfossiliferous, the lowermost clay has a sparse Albian fauna. The
Miocene/Cretaceous unconformity correlates with reflecting horizon $A$. We suspect that there was submarine weathering at this position because of the presence of some bright orange, oxidized shale layers in the uppermost 2-3 meters of the Cretaceous unit.

Below the reduced black clay a 75-meter thick "transition"' zone of Aptian claystone, at the top, grades downward into limestone. The base of this series probably correlates with reflecting horizon $\beta$.

Below horizon $\beta$ another prominent reflector $\mathrm{C}$ correlates with the top of Tithonian limestones. This reflector is basin-wide and also occurs elsewhere in the Atlantic.

\section{Lower Cretaceous and Jurassic}

We recovered the most complete Lower Cretaceous upper Tithonian sequence found thus far in the deep oceans. Equivalent beds were found during Leg 11 (Sites 101, 105), but at Site 101 the base of the unit was not reached. Moreover, Sites 101 and 105 were on the seaward structural margins of the basin warped deeper toward the continent and their total thickness is about half that of Site 391.

The white and gray Neocomian limestones are of several types: carbonate turbidites, calcilutites, and an unusual sequence of very finely laminated beds whose origin is somewhat puzzling. No sharp break marks the Jurassic/Cretaceous boundary, which falls in the light colored limestone near the bottom of lithologic unit 4 .

Below 1324 meters, the light colored upper Tithonian limestone gives way to lower Tithonian, red and greenish limestone and at 1371 meters these are underlain by lower Tithonian (and upper Kimmeridgian) dark red ammonite-bearing marls.

The Lower Cretaceous section is expanded and the transition across the Cretaceous/Jurassic boundary is gradual. Because of this and the good to excellent preservation of the nannofossil assemblages in this limestone, Hole $391 \mathrm{C}$ offered an excellent opportunity to establish the biostratigraphic control for comparison with the land zonations presently tied to the type section. Indeed, the expanded section and good fossil preservation make Site 391 ideal for an even better-defined zonation than the equivalent land section in France.

\section{Western North Atlantic Lithologic Synthesis}

On the basis of this excellent section at Site 391, a more precise time-stratigraphic correlation between western North Atlantic DSDP holes which have penetrated the Lower Cretaceous/Jurassic is now possible (Figure 31). The

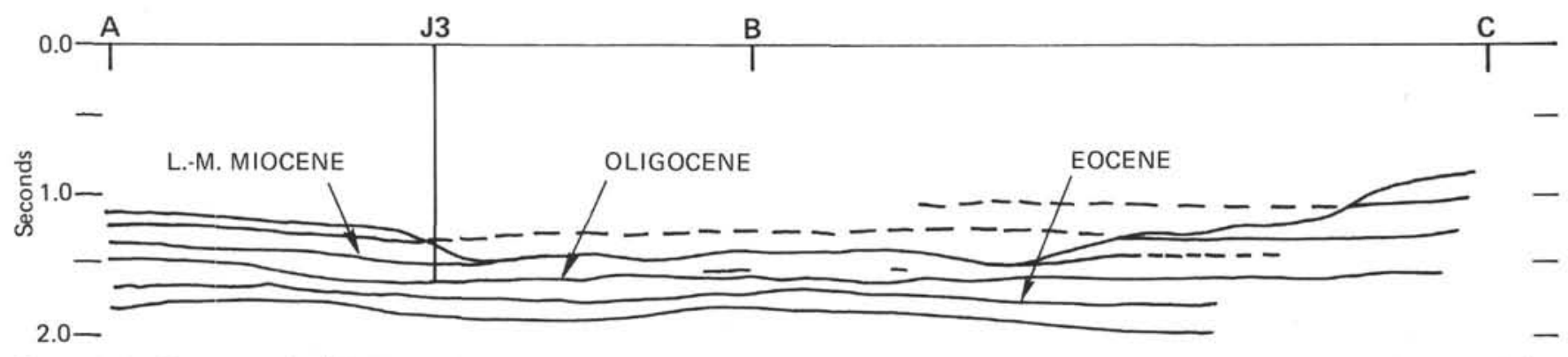

Figure 29. Tracing of $R / V$ Conrad seismic reflection profile showing missing Miocene section on the Blake Plateau (after Ewing et al., 1966). Position of JOIDES Hole J3 is also shown. 


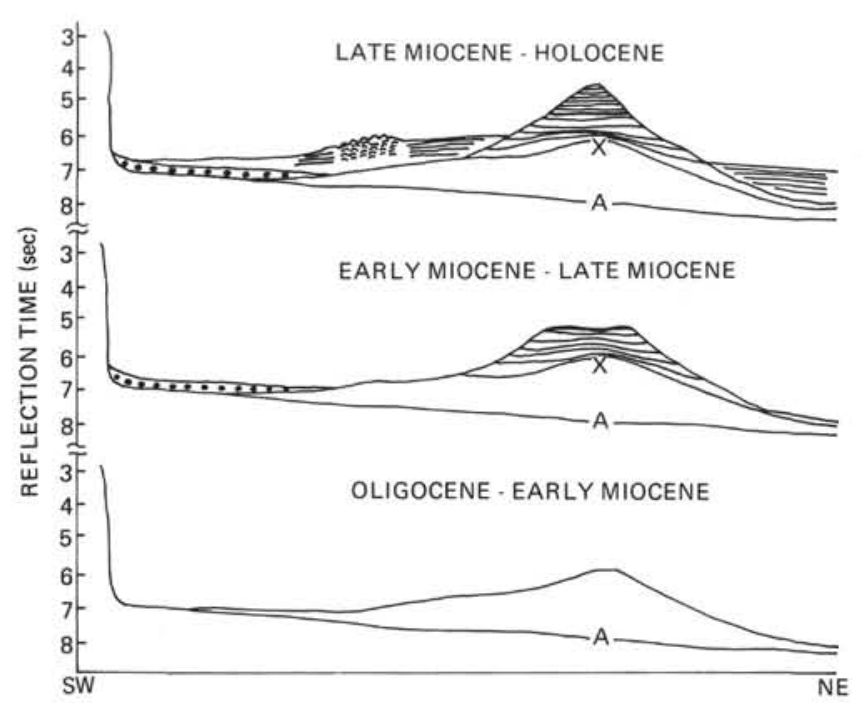

Figure 30. Diagrammatic cross-sections of Blake Outer Ridge showing reconstruction of sedimentary build-up through middle and late Tertiary and Quaternary (modified after Ewing and Hollister, 1972). Early-late Miocene turbidite sequence is shown as heavy line representing ponding of this layer west of the ancient Blake Outer Ridge (after Sheridan et al., 1974).

nannofossil stratigraphic zones, as defined by Thierstein (1973), restrict the age of most of the white and gray limestone to Neocomian (Lowest Cretaceous), specifically Berriasian through Barremian, with only the lower unit (4d) being upper Tithonian (uppermost Jurassic). Previously, the entire white and gray limestone unit was lumped in the Neocomian-Tithonian. Also, in the uppermost Jurassic at previously drilled sites there was some confusion about the Tithonian/Kimmeridgian/Oxfordian boundaries and the ?Callovian limestone recovered at Site 100 did not seem to fit in this new nannofossil zonation. Now that the Tithonian-Kimmeridgian time equivalency is apparently accepted, some adjustment is required in the stratigraphic nomenclature used at Sites 100 and 105.

Within the basin bounded on the northwest by the continental slope, on the northeast by Kelvin Seamounts, on the southeast by Bermuda Rise, and on the southwest by the Blake-Bahama Escarpment, the sedimentary units are correlative lithologically as well as paleontologically and may have broad mappable lateral extent (Figure 31). Lancelot et al. (1972) in their synthesis of Leg 11 defined eight basic sedimentary units on the basis of data from Sites 99, 100, 101, 105, and 106 (Figure 31). The units, which they numbered 2 through 9 , are as follows:

2) Oxfordian gray-green limestone

3) Kimmeridgian-Oxfordian red clayey limestone

4) Neocomian-Tithonian white and gray limestone

5) Neocomian-Tithonian nannofossil chalk

6) Cenomanian-Aptian black carbonaceous clay

7) Upper Cretaceous-lower Tertiary variegated oozes

8) Miocene-Pliocene gray-green hemipelagic mud

9) Pleistocene-Holocene hemipelagic clay and sand

On Leg 44 at Sites 388 and 391 we cored Leg 11 units 3, 4, 6, 8, and 9 (Lancelot et al., 1972); we did not penetrate Leg 11 unit 2, which was beyond the reach of the drill by probably less than 50 meters. Nor did we sample Leg 11 unit 5 which is present locally in the Cat Gap area where it is semi-consolidated - probably because of shallow burial. We cored only a very attenuated unit 7 which had possibly been eroded under the horizon $A$ unconformity.

The unusual Miocene turbidites and gravity flows cored at Site 391, unique to that epoch and confined to the Blake-Bahama Basin, represent a distinctly different stratigraphic unit to be added to the Lancelot et al. (1972) grouping. In addition, the seismic reflection profile in the Blake-Bahama Basin clearly shows an additional sedimentary unit below a deep reflector which probably represents a distinct formation below what might be projected as Lancelot et al. (1972) unit 2.

We have attempted to integrate the Site 391 stratigraphy into the previously defined stratigraphic framework. Thus, we have modified and expanded the definition of lithologic units in the Western Atlantic beyond what has been done by Lancelot et al. (1972). We have synthesized these data in a cross-section which shows our redefined units and related data from our Leg 44 sites to those of Leg 11 and the more recently drilled sites of Leg 43 (Tucholke, Vogt et al., 1975) (Figure 31).

The newly defined lithological units are (Figure 31):

Lithofacies 1: An as yet unsampled lithologic unit deposited during the early opening of the Atlantic. It is identified to date only as well-defined layers on seismic profiles - especially those taken in the Blake-Bahama Basin. Knowledge of the lithology of these units awaits future drilling in the Blake-Bahama Basin.

Lithofacies 2: Gray-green Oxfordian limestone (unit 2 of Lancelot et al., 1972) and Kimmeridgian and Oxfordian red marl and clayey limestone (unit 3 of Lancelot et al., 1972).

Lithofacies 3: Gray and white Neocomian and uppermost Tithonian limestones (unit 4 of Lancelot et al., 1972).

Lithofacies 3a: A chalk/limestone equivalent in age to unit 3 , but apparently less well consolidated and confined to the Cat Gap area.

Lithofacies 4: A sequence of dark green to black clays probably the most easily recognized and persistent formation in the western North Atlantic Basin (unit 6 of Lancelot et al., 1972). The formation comprises Aptian upward through Cenomanian and possibly younger sediments.

Lithofacies 5: This lithologic unit encompasses Upper Cretaceous variegated clays cored at Site 105 (Lancelot et al., 1972) and more recently at Sites 386 and 387 of Leg 43 (Tucholke, Vogt et al., 1975). It is best developed and documented at Site 386 on the Bermuda Rise, where it is about 100 meters thick and is often missing or greatly thinned below the horizon $A$ unconformity (e.g., at Sites 391 and 101).

Lithofacies 6: Paleocene-Eocene siliceous ooze and chert which includes the cherts of horizon $A$. Lithofacies 6 has been best sampled in the eastern part of the basin; it is completely missing in the southwestern part of the basin at Sites 100,101 , and 391.

Lithofacies 7: Miocene through Pleistocene hemipelagic sediments. The hemipelagic sediments cored at Sites 102, 103 and 104 best typify this unit. The topographic continental rise off Cape Hatteras is a prism formed of this 

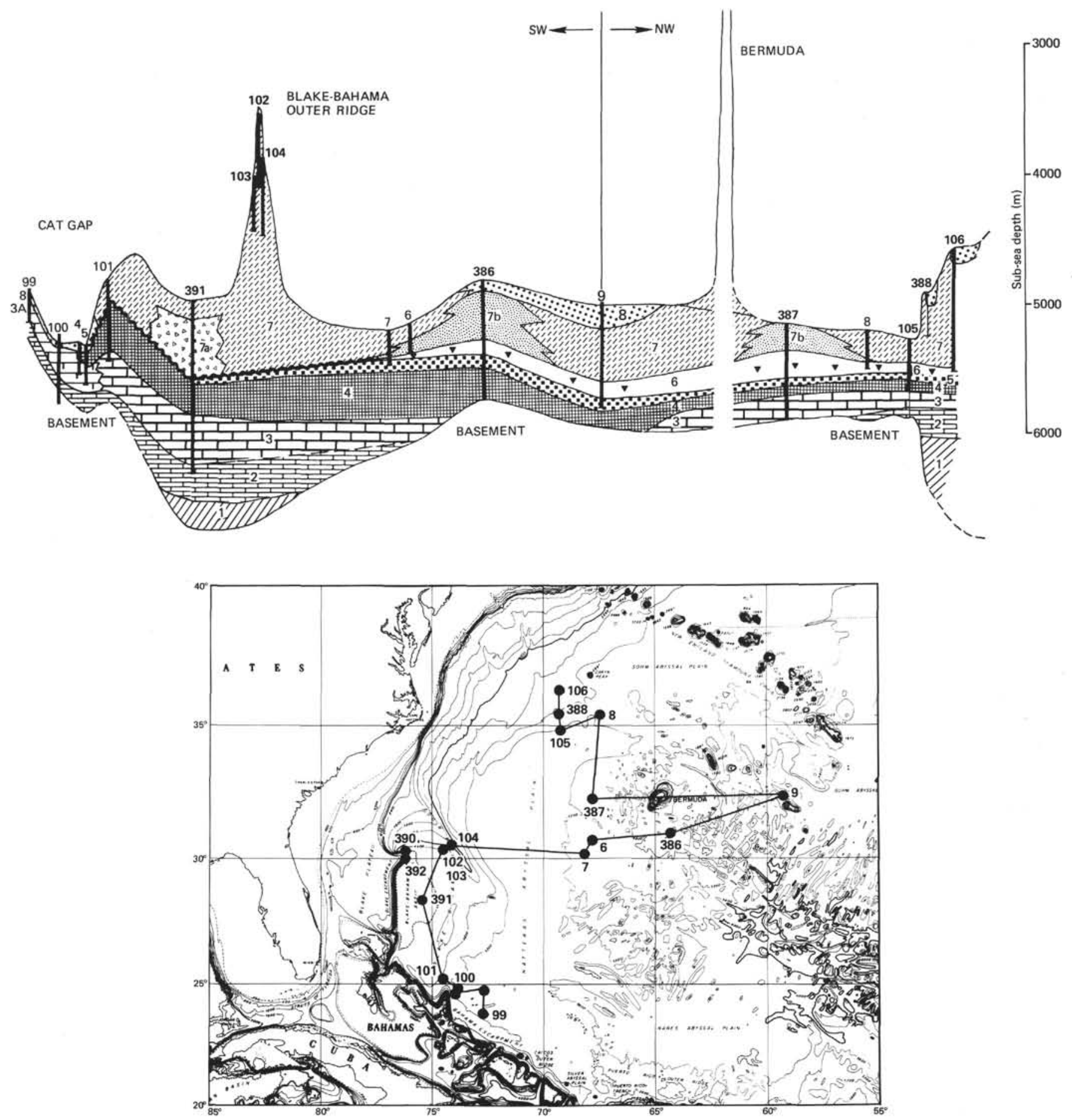

Figure 31. Synthesis of deep-sea drilling results in the western North Atlantic.

sediment, much of which may have piled on the rise by contour currents.

Lithofacies 7a: A $\mp 500$-meter-thick turbidite and gravity flow deposit confined to the Blake-Bahama Basin. It was cored for the first time and extensively sampled at Site 391 . The Great Abaco Canyon probably acted as a conduit for these sediments as they flushed from the Blake Plateau. Lithofacies $7 \mathrm{a}$ reflects a local variation of the overall Miocene depositional environment.

Lithofacies 7b: This unit has a highly variable lithology and includes predominantly zeolitic clays with graded carbonate sands, graded biogenic silica and radiolarian mud. It was deposited over a long time span - from middle Eocene through Pleistocene - and is best developed on the Bermuda Rise at Sites 386-387 (Tucholke, Vogt, et al., 1975).

Lithofacies 8: Pleistocene-Holocene sands and turbidites (unit 9 of Lancelot et al., 1972). This lithofacies is well developed at Site 106 where it was probably deposited by turbidity currents from the nearby Hudson submarine canyon.

A more detailed description of the lithofacies described above is presented in Sheridan, Enos, Gradstein, and Benson (synthesis chapter of this volume). 


\section{REFERENCES}

Bernard, T. and Hay, W. W., 1974. On Jurassic coccoliths: A tentative zonation of the Jurassic of Southern England and North France: Eclog. Geol. Helv., v. 67, p. 563-585.

Barrett, D. L. and Keen, C. E., 1976. Mesozoic magnetic lineations, the Magnetic Quiet Zone, and sea floor spreading in the Northwest Atlantic: J. Geophys. Res., v. 81, p. $4875-4884$.

Bartenstein, H., 1976. Practical applicability of a zonation with benthonic foraminifera in the worldwide Lower Cretaceous: Geol. Mijnbouw, v. 55, p. 83-86.

Blow, W. H., 1967. Late middle Eocene to Recent planktonic foraminiferal biostratigraphy: Plankt. Conf. Proc. I, Geneva, v. 1, p. $199-422$.

Boyce, R.E., 1973. Physical properties-methods. In Edgar, N.T., Saunders, J.B., et al., Initial Reports of the Deep Sea Drilling Project, Volume 15: Washington (U.S. Government Printing Office), p. 1115-1124.

Dieni, I. and Massari, F., 1966. I Foraminiferi del Valanginiano Superiore di Orosei (Sardegna): Palaeont. Italica, v. 61, p. 75-186.

Dillon, W. P., Sheridan, R. E., and Fail, J. P., 1976. Structure of the western Blake-Bahama Basin as Shown by 24 Channel CDP profiling: Geology, v. 4, p. 459-462.

Drake, C. L., Heirtzler, J. R., and Hirschman, J., 1963. Magnetic anomalies off Eastern North America: J. Geophys. Res., v. 68, p. 5259-5275.

Ewing, J. I., Ewing, M., and Leyden, R., 1966. Seismic-profiler survey of Blake Plateau: Am. Assoc. Petrol. Geol. Bull., v. 50 , p. $1948-1971$.

Ewing, J.I. and Hollister, C.D., 1972. Regional aspects of deep sea drilling in the western North Atlantic. In Hollister, C.D., Ewing, J.I., et al., Initial Reports of the Deep Sea Drilling Project, Volume 11: Washington (U.S. Government Printing Office), p. 951-973.

Farinacci, A., 1965. I foraminiferi di un livello marnoso nei calcari dia springni del Malm (Monti Martani, Umbria): Geol. Romano, v. 4, p. 229.

Gieskes, J. M., 1974. Interstitial water studies, Leg 25. In Vallier, T.L., White, S.M., et al., Initial Reports of the Deep Sea Drillig Project, Volume 25: Washington (U.S. Goverment Printing Office), p. 361-374.

Gieskes, J.M. and Lawrence, J.R., 1976. Interstitial water studies, Leg 35. In Hollister, C.D., Craddock, C., et al., Initial Reports of the Deep Sea Drilling Project, Volume 35: Washington (U.S. Goverment Printing Office), p. 407-424.

Goodell, H. G. and Garman, R. K., 1969. Carbonate geochemistry of superior Deep Test Well, Andros Island, Bahamas: Am. Assoc. Pet. Geol. Bull., v. 53, p. 513-536.

Gordon, W. A., 1970. Biogeography of Jurassic Foraminifera: Geol. Soc. Am. Bull., v. 81, p. 1689-1704.

Gradstein, F. M., Williams, G. L., Jenkins, W. A. M., and Ascoli, P., 1975. Mesozoic and Cenozoic stratigraphy of the Atlantic Continental Margin, Eastern Canada. In Yorath, C. J., Parker, E. R., and Glass, D. J. (eds.), Canada's Continental Margins and Offshore Petroleum Exploration: Canadian Soc. Petrol. Geol., Memoir 4, p. 103-133.

Gradstein, F. M., in press. Biostratigraphy and biogeography of Jurassic Grand Banks foraminifera: Proc. I Benthonic Conf., "'Benthonics "'75", Halifax, N.S., 1975.

Hollister, C. D., Ewing, J. I., et al., 1972. Initial Reports of the Deep Sea Drilling Project, Volume II: Washington (U.S. Government Printing Office).

Jansa, L. F., Gradstein, F. M., Harris, I. M., Jenkins, W. A. M. and Williams, G. L., 1976. Stratigraphy of the Amoco IOE
Murre G-67 Well, Grand Banks of Newfoundland: Geol. Surv. Canada, Paper 75-30.

Krasheninnikov, V. A., 1973. Cretaceous benthonic foraminifera, Leg 20, Deep Sea Drilling Project. In Heezen, G. C., MacGregor, I. D., et al., Initial Reports of the Deep Sea Drilling Project, Volume 20: Washington (U.S. Government Printing Office), p. 205-219.

Lancelot, Y., Hathaway, J. C., and Hollister, C. D., 1972. Lithology of sediments from the Western North Atlantic Leg 11 Deep Sea Drilling Project. In Hollister, C. D., Ewing, J. J., et al., Initial Reports of the Deep Sea Drilling Project, Volume 11: Wasinington (U.S. Government Printing Office), p. 901-949.

Larson, R. L. and Hilde, 1975. A revised time scale of magnetic reversals for the Early Cretaceous, Late Jurassic: J. Geophys. Res., v. 80, p. 2586-2594.

Loeblich, A. R. and Tappan, H., 1964. Treatise on Invertebrate Paleontology. In Moore, R. C. (Ed.), pt. C, protista 2 (Sarcodina, chiefly "Thecamoebians" and Foraminiferida), $\mathrm{XXXI},+900 \mathrm{p}$.

LePichon, X., Francheteau, J., and Bonnin, J., 1973. Plate tectonics (developments in geotectonics 6): New York (Elsevier Sci. Publ. Company), p. 1-300.

Luterbacher, H.P. (1972) Foraminifera from the Lower Cretaceous and Upper Jurassic of the Northwestern Atlantic. In Hollister, C. D., Ewing, J. I., et al., Initial Reports of the Deep Sea Drilling Project, Volume 11: Washington (U.S. Government Printing Office), p. 561-593.

Markl, R. G., Bryan, G. M., and Ewing, J. I., 1970. Structure of the Blake-Bahama Outer Ridge: J. Geophys. Res., v. 75, p. $4539-4555$

Ohm, U., 1967. Zur Kenntnis der Gattungen Reinholdella, Garantella und Epistomina (Foramin.): Palaeontographica A, no. 127 , p. $103-188$.

Osburn, W. L., 1975. Geophysical Study of the Great Abaco Fracture Zone: Ph.D. Dissertation, University of Delaware.

Pazdro, O., 1969. Middle Jurassic Epistominidae (Foraminifera) of Poland: Studia Geologica Polonica, v. 27, p. 1-92.

Pazdrowa, O., 1969. Bathonian Globigerina of Poland: Ann. Soc. Geol. Pologne, v. 39, p. 41-56.

Riedel, W. R. and Sanfilippo, A., 1974. Radiolarian biostratigraphy (Planktonic Conf. Kiel, in press).

Ryan, W.B.F., Cita, M.B., Dreyfus Rawson, M., Burckle, L.H., and Saito, J., 1974. A paleomagnetic assignment of Neogene stage boundaries and the development of isochronous datum planes between the Mediterranean, the Pacific and Indian Oceans in order to investigate the response of the world ocean to the Mediterranean "salinity crisis,"' Riv. Ital. Paleontol. v. 80 , p. $631-688$.

Schlee, J. and Gerard, R., 1965. Cruise report and preliminary core Log M/V Caldrill I, 17 April to 17 May 1975: Tech. Rept. NSF Grant GP-4233.

Sheridan, R. E., Drake, C. L., Nafe, J. E., and Hennion, J., 1966. Seismic refraction study of Continental Margin East of Florida: Am. Assoc. Petrol. Geol. Bull., v. 50, p. 1972-1991.

Sheridan, R. E., Berman, R. M. and Corman, D. B., 1971. Faulted limestone block dredged from Blake Escarpment: $\mathrm{Am}$. Assoc. Pet. Geol. Bull., v. 82, p. 199-206.

Sheridan, R. E., Golovchenko, X., and Ewing, J. I., 1974. Late Miocene turbidite horizon in the Blake-Bahama Basin: $\mathrm{Am}$. Assoc. Petrol. Geol. Bull., v. 58, p. 1797-1805.

Sheridan, R. E. and Osburn, W. L., 1975. Marine Geological and Geophysical Investigations of the Florida-Blake Plateau-Bahamas Area: Canadian Soc. Petrol. Geol., Mem. 4, p. $9-32$.

Simoneit, B. R., Scott, E. S., and Burlingame, A. L., 1973. 
Preliminary organic analysis of DSDP Cores, Leg 14, Atlantic Ocean: Initial Reports of the Deep Sea Drilling Project, Volume 16, 17

Taylor, P. T., Zietz, I., and Dennis, L. S., 1968. Geologic implications of aeromagnetic data for the Eastern Continental Margin of the United States: Geophysics, v. 33, p. 755-780.

Thierstein, H. R., 1971. Tentative Lower Cretaceous Nannoplankton Zonation: Eclog. Geol. Helv., v. 64, p. $459-488$.
(1973). Lower Cretaceous calcareous nannoplankton biostratigraphy: Abh. Geol. Bundesanstalt Wien, v. 29, p. $1-52$.

Tucholke, B. and Vogt, P., et al., 1975. Glomar Challenger drills in the North Atlantic: Geotimes, v. 20, p. 18-21.

van Hinte, J. E., 1976a. A Jurassic Time Scale: Am. Assoc. Petrol. Geol., v. 60, p. 489-497.

1976b. A Cretaceous Time Scale: Amer. Assoc. Petrol. Geol. Bull., v. 60, p. 498-516. 


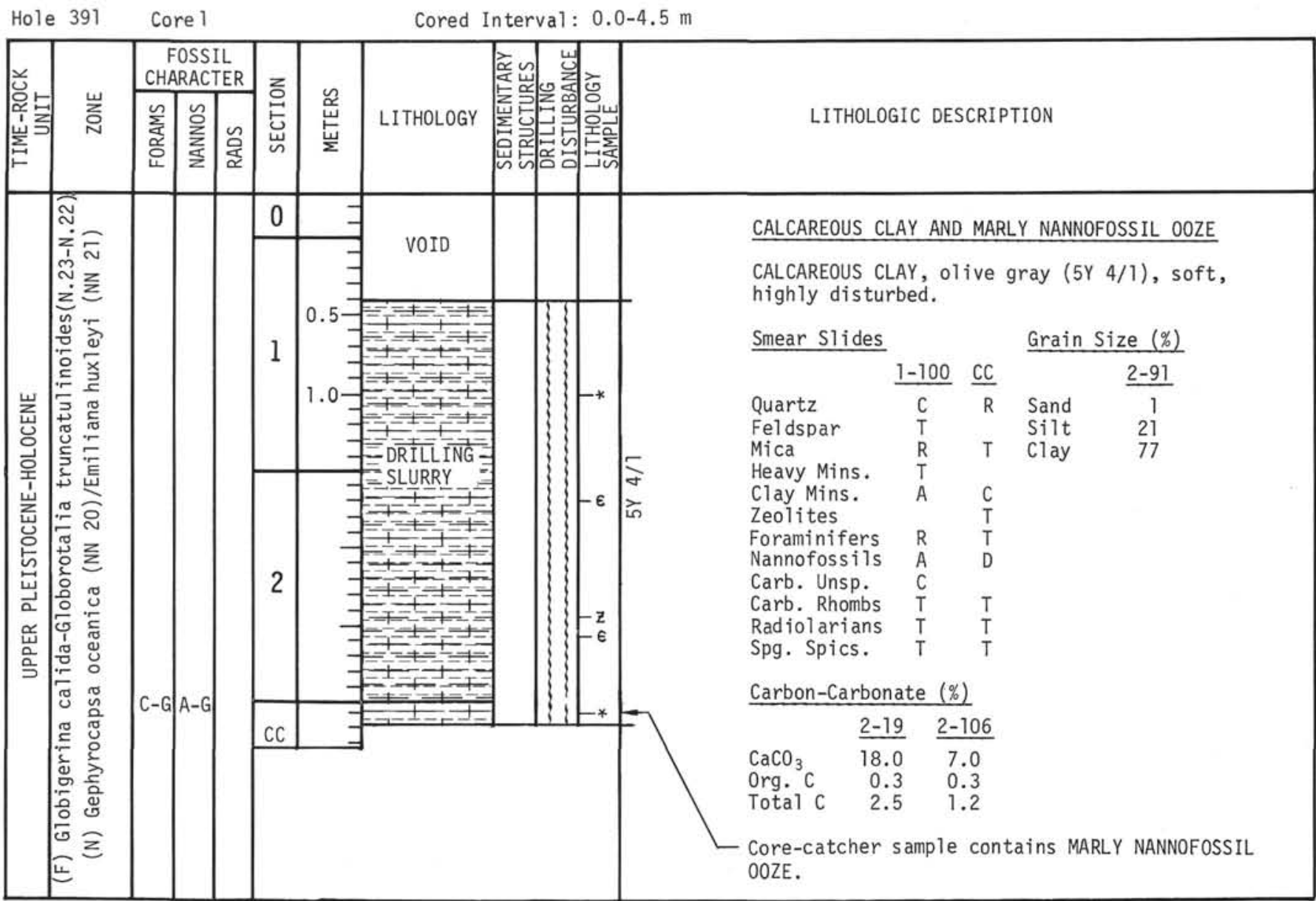




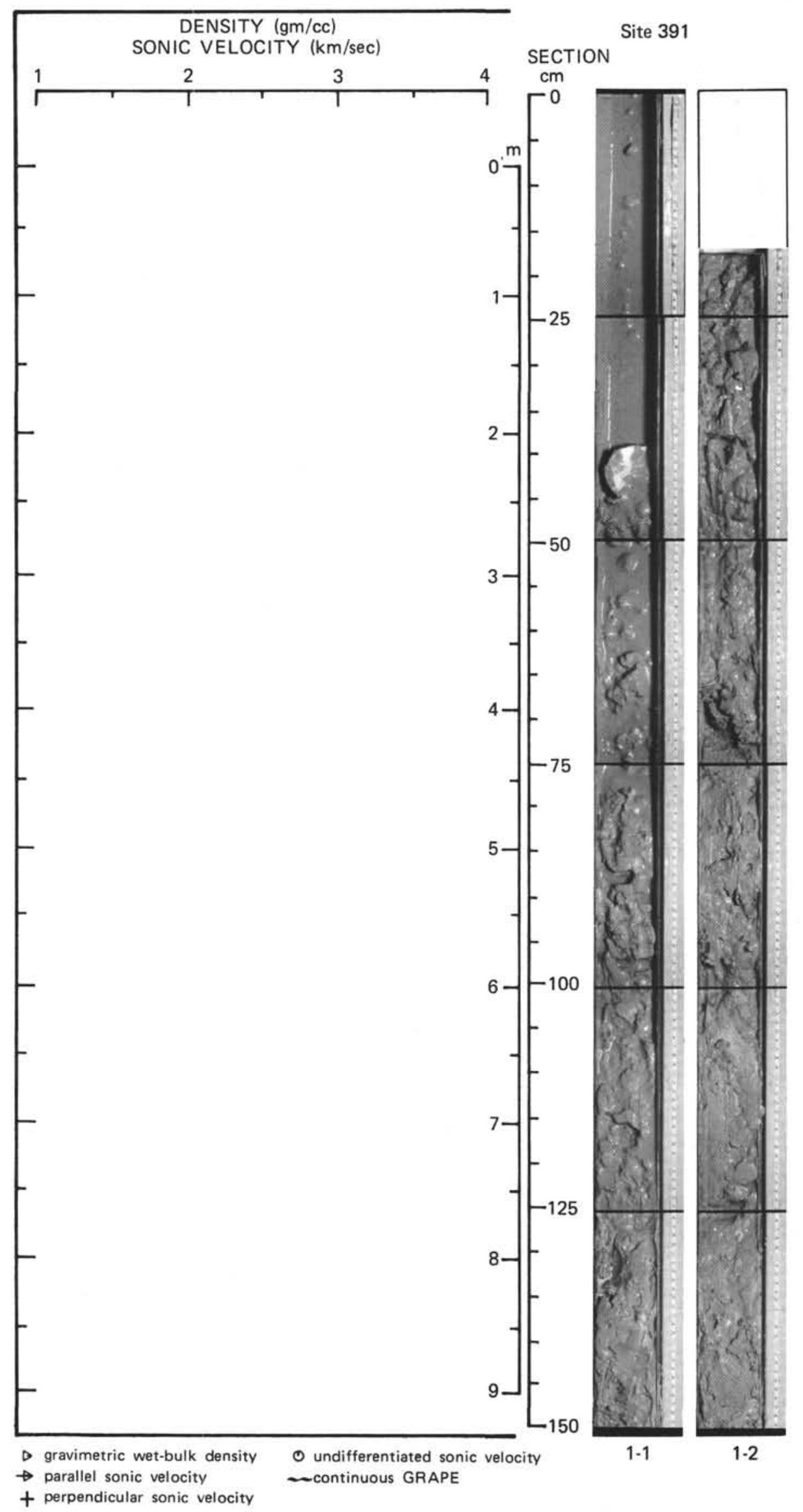


Hole $391 \mathrm{~A}$ Core 1 Cored Interval: 86.0-95.5 m

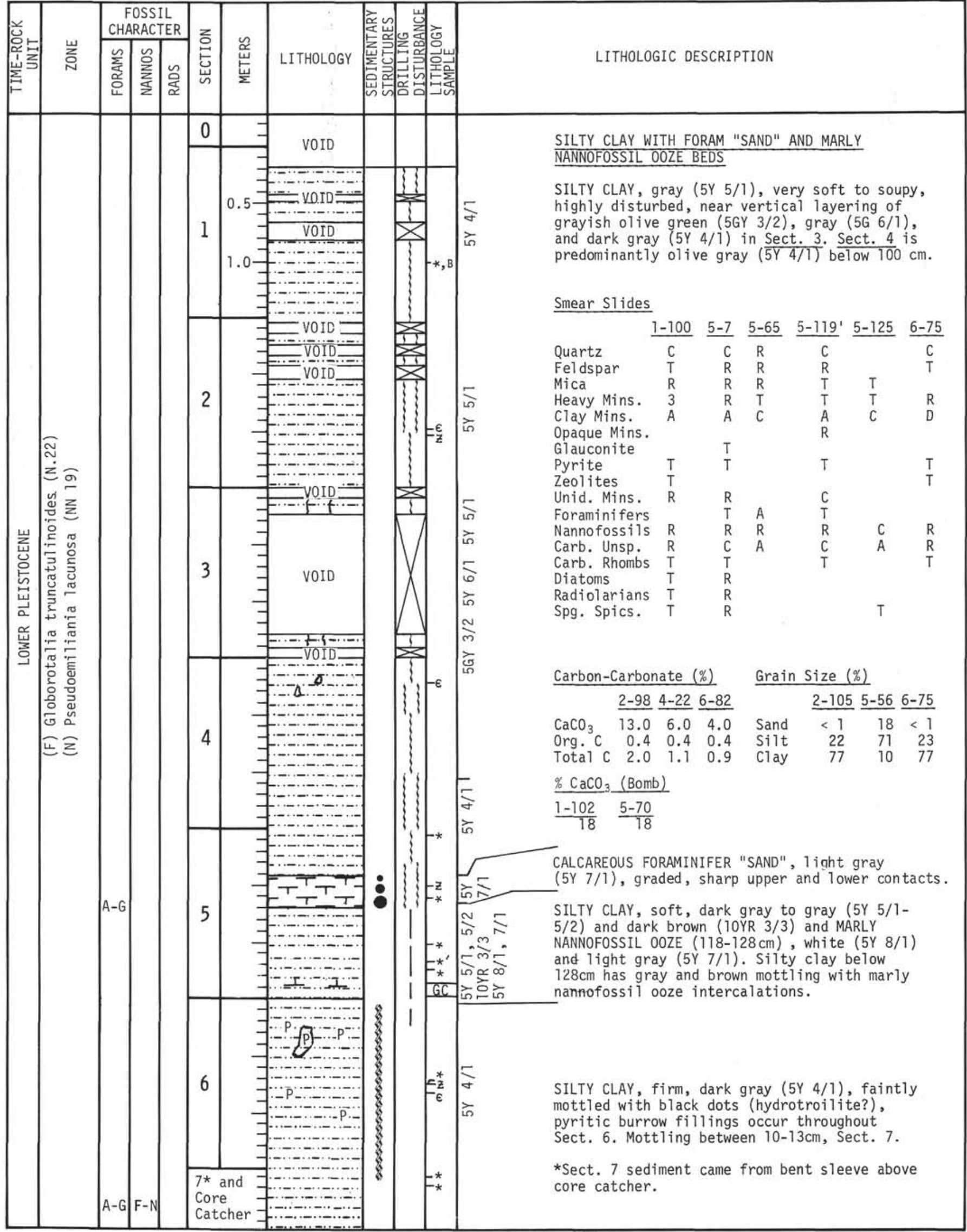




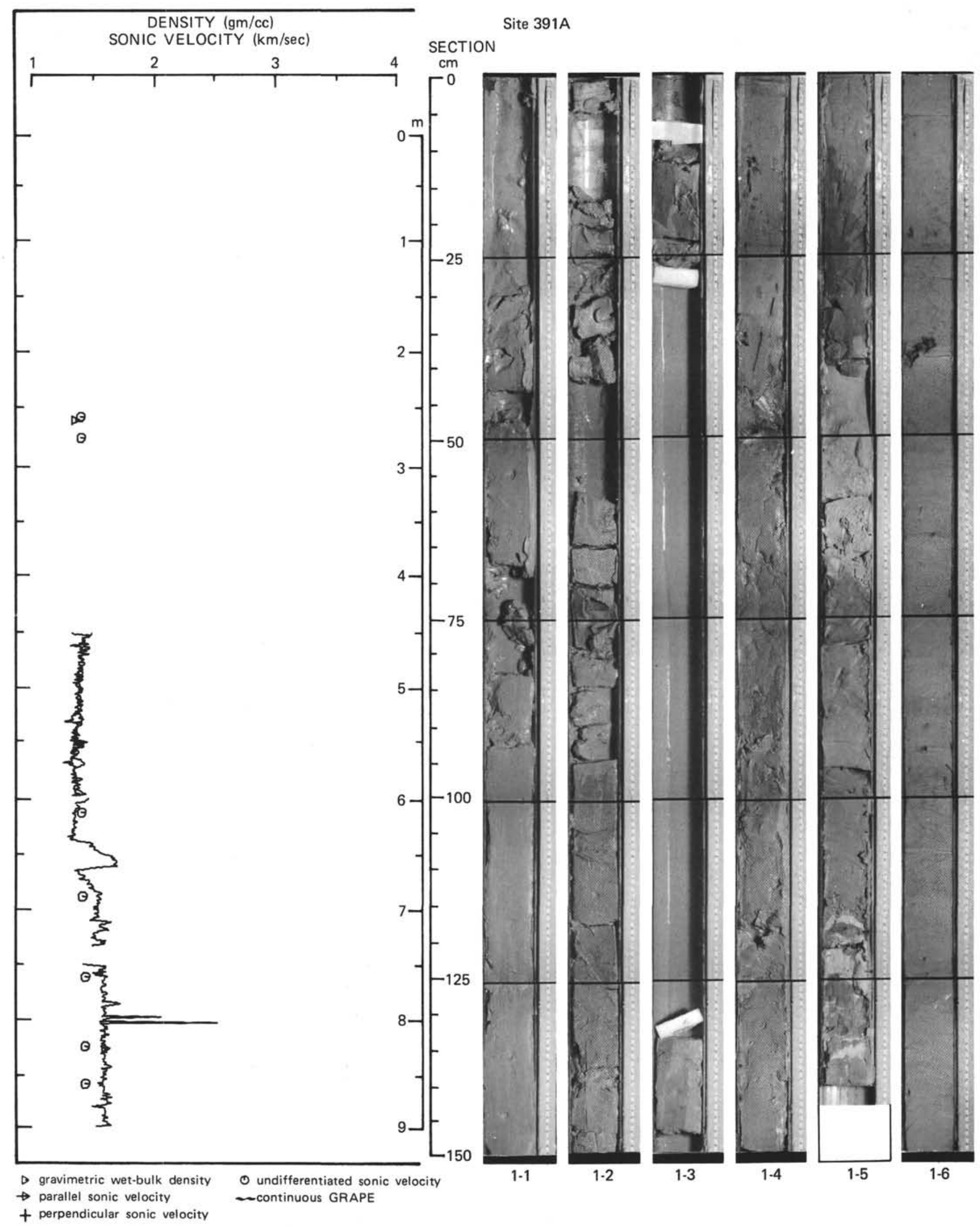


Hole 391A Core 2

Cored Interval: $31.5-41.0 \mathrm{~m}$

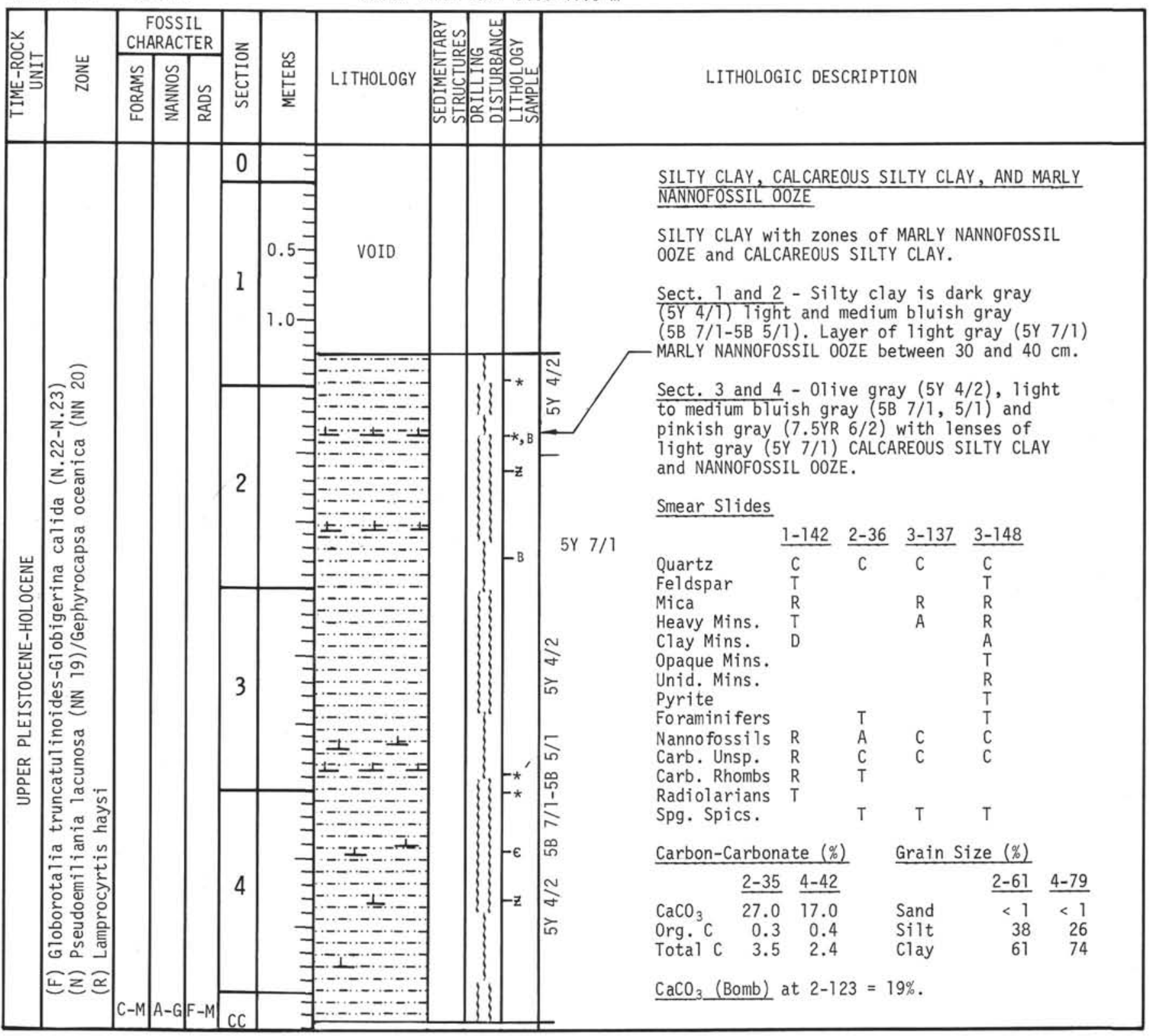




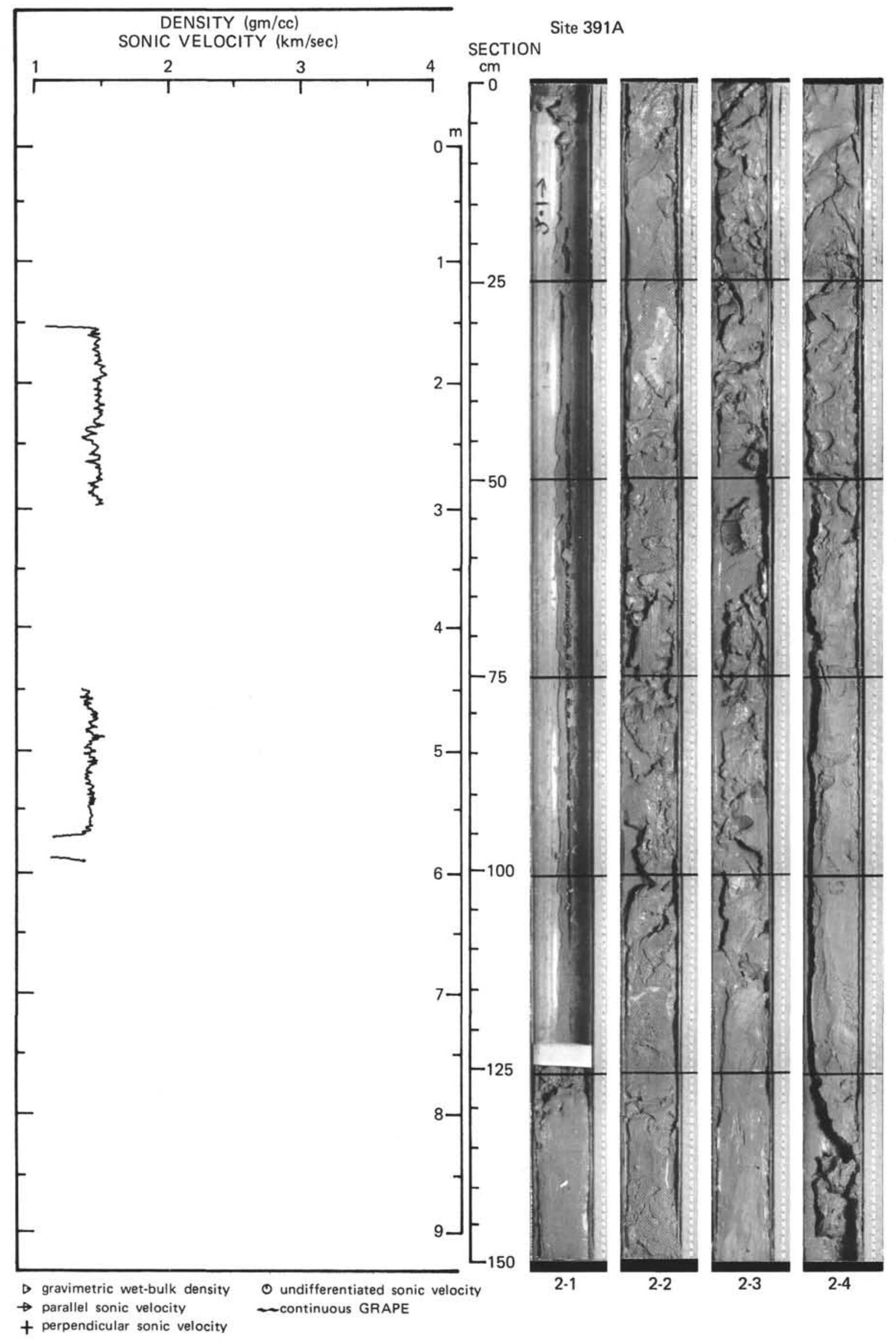




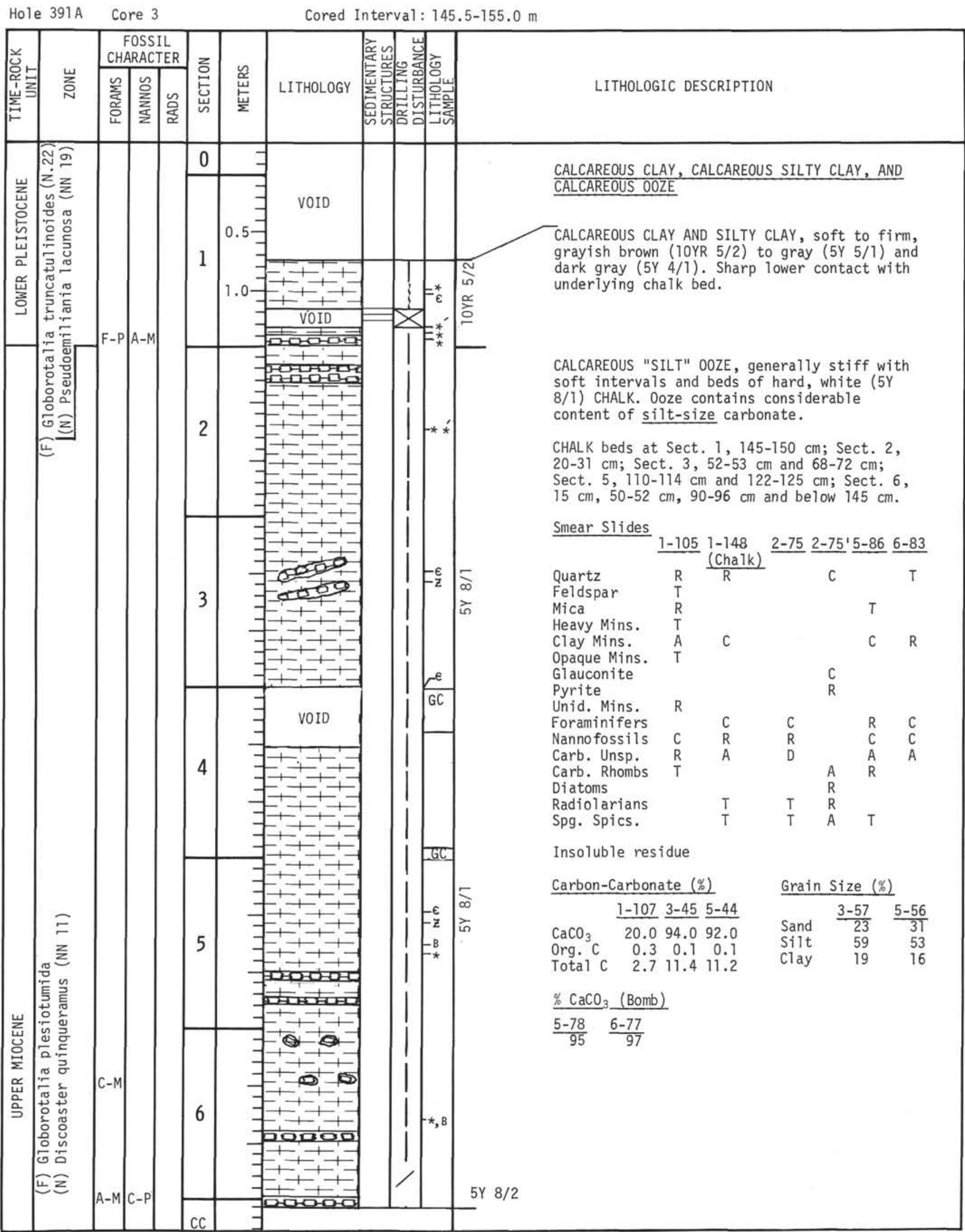




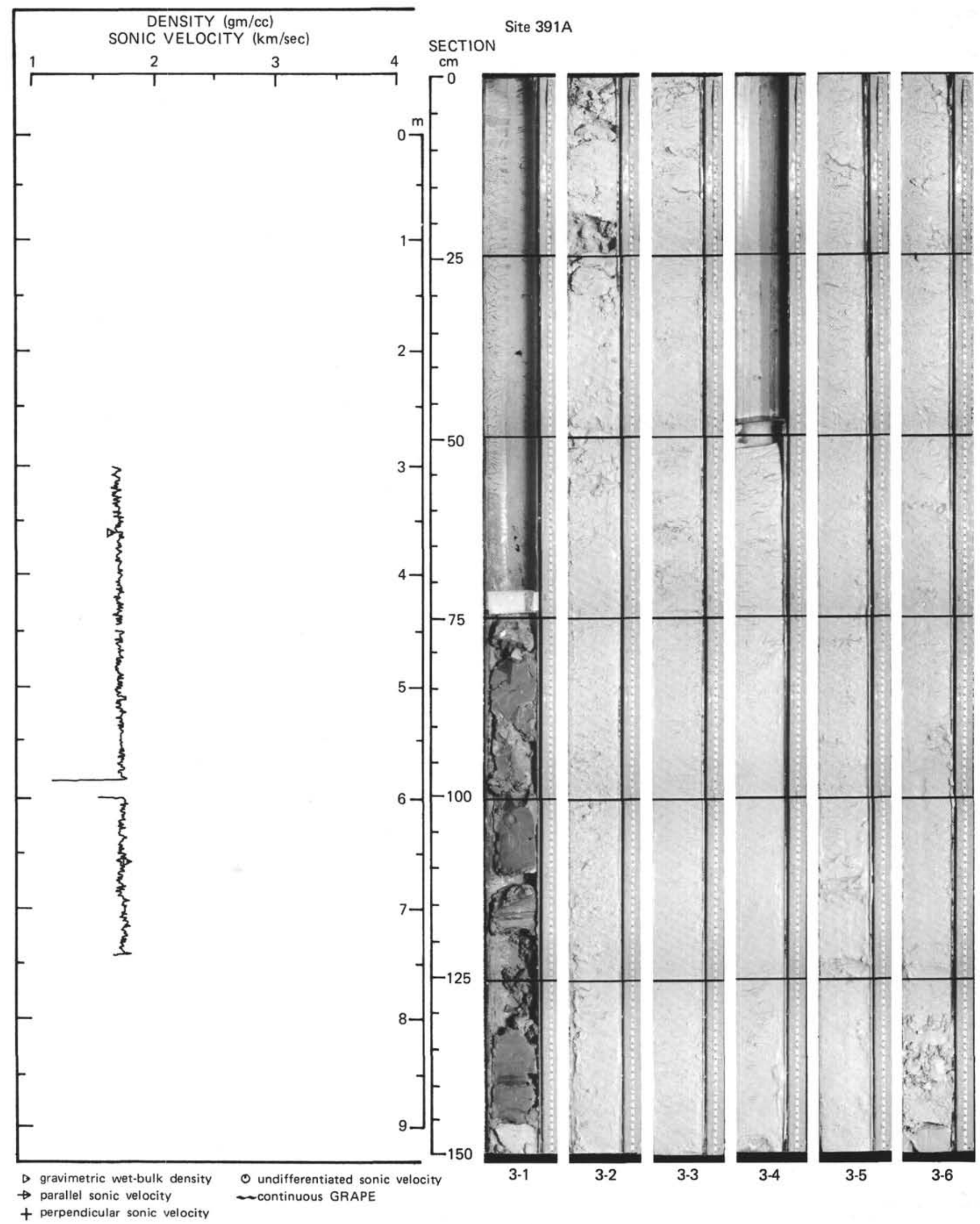




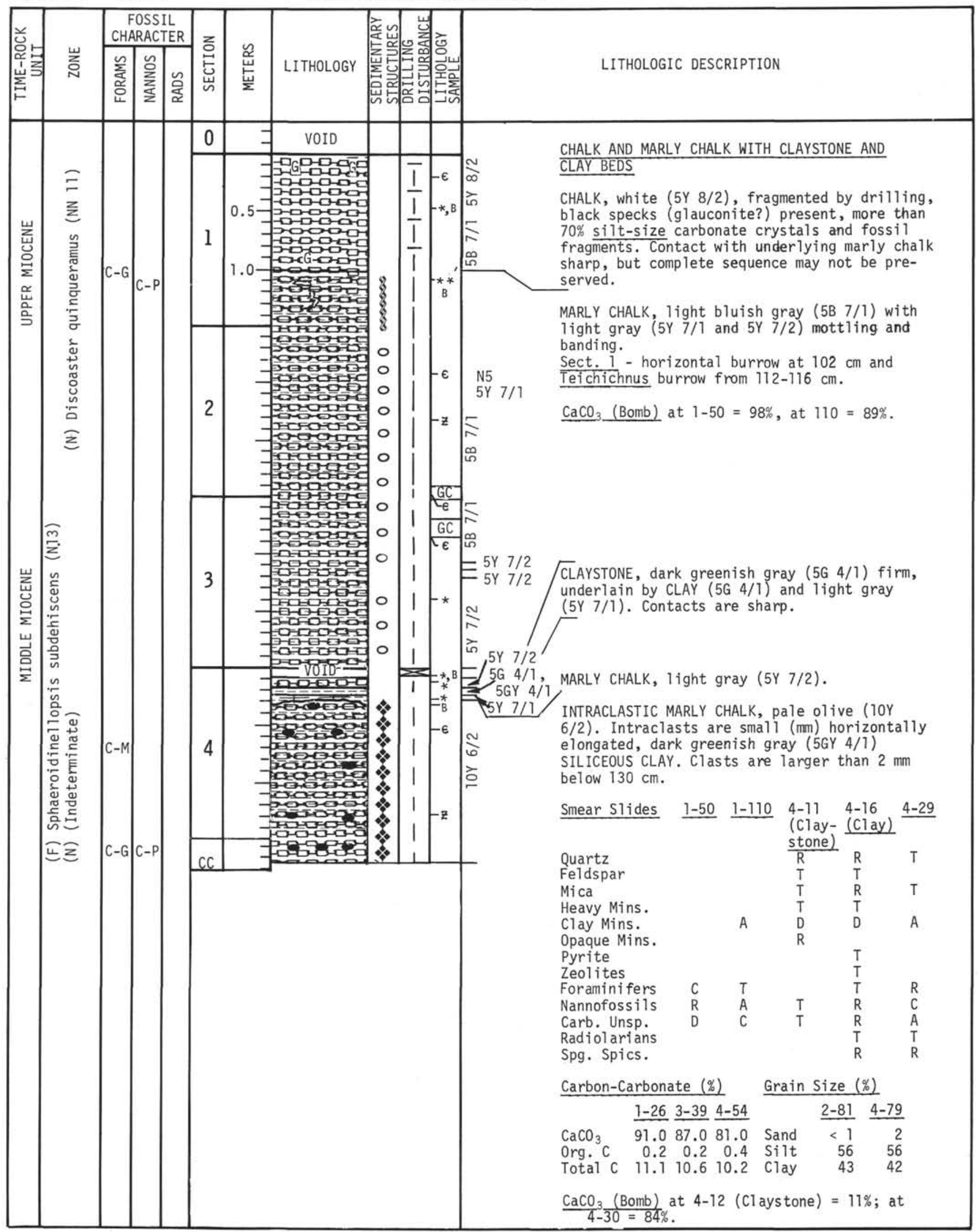




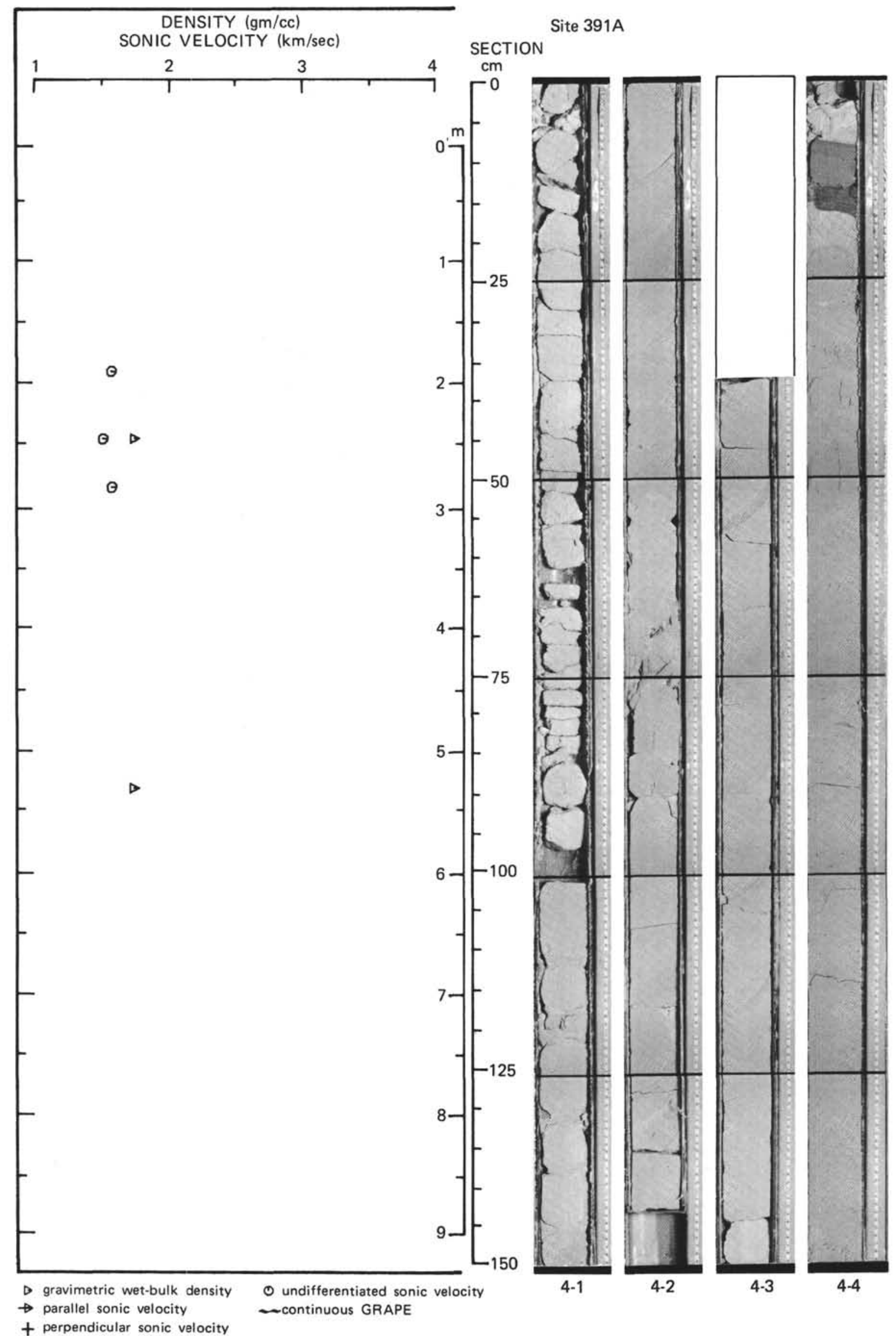


Hole 391 A Core 5

Cored Interval: 259.5-269.0 m

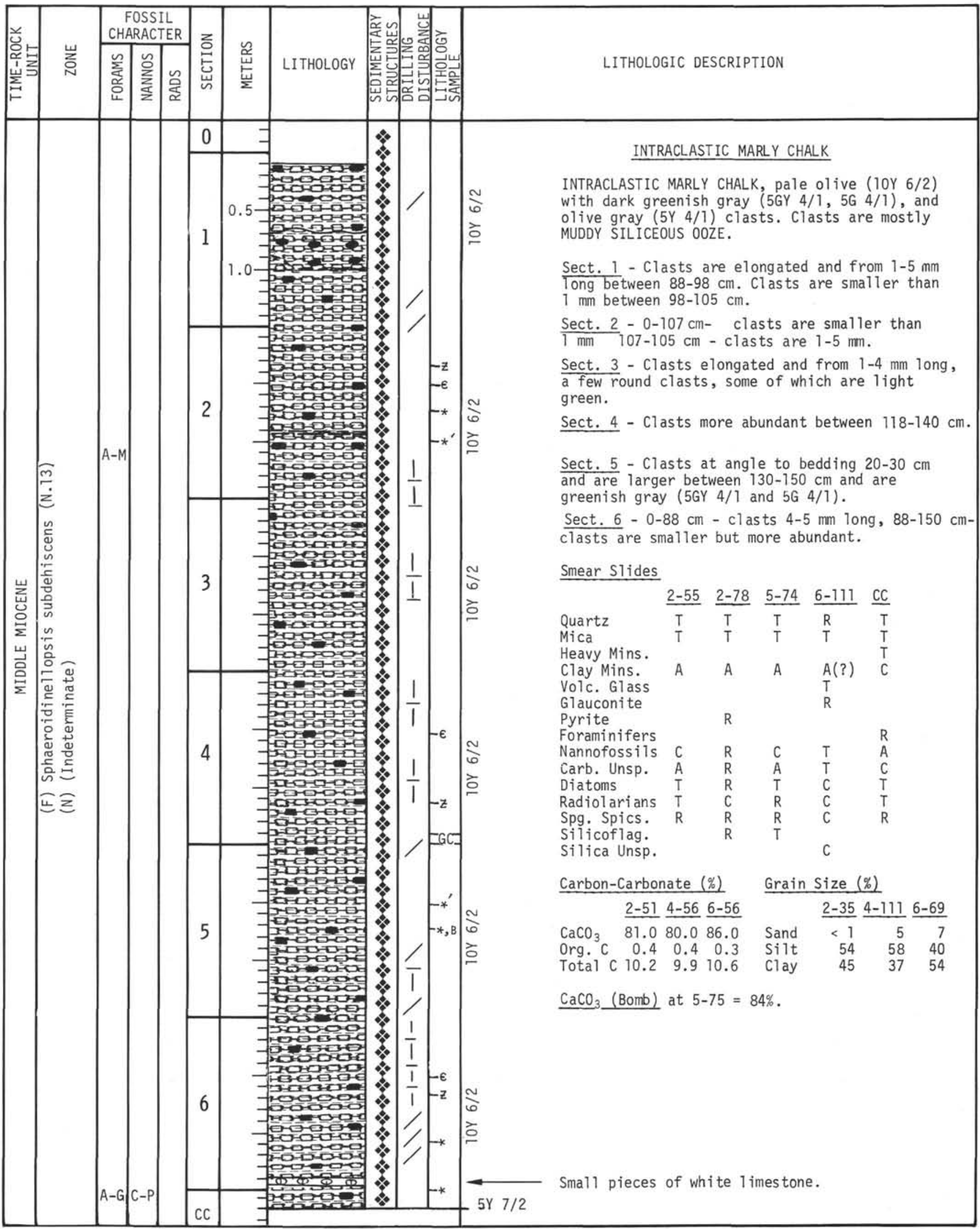




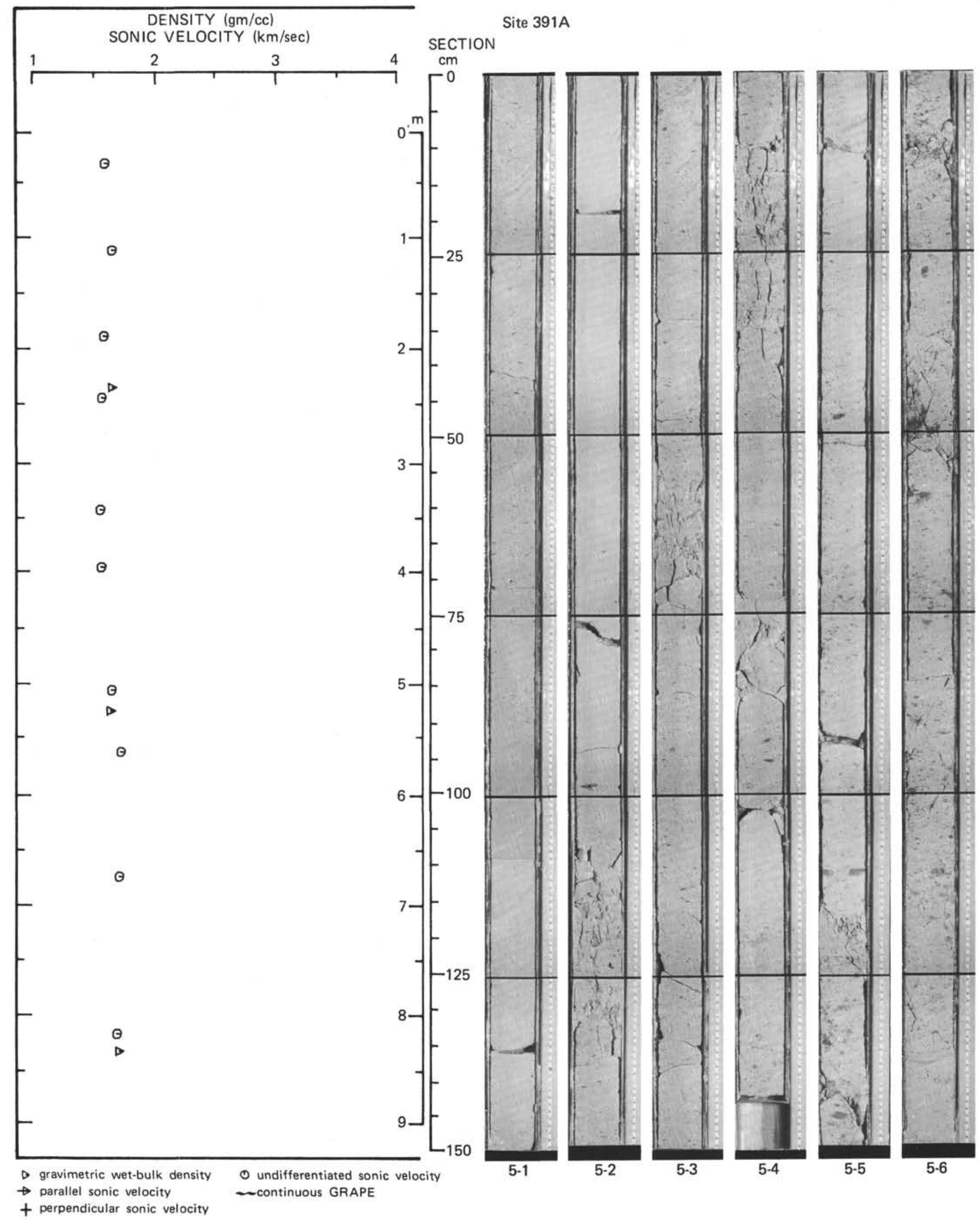


Hole 391 A Core 6

Cored Interval: $316.5-326.0 \mathrm{~m}$

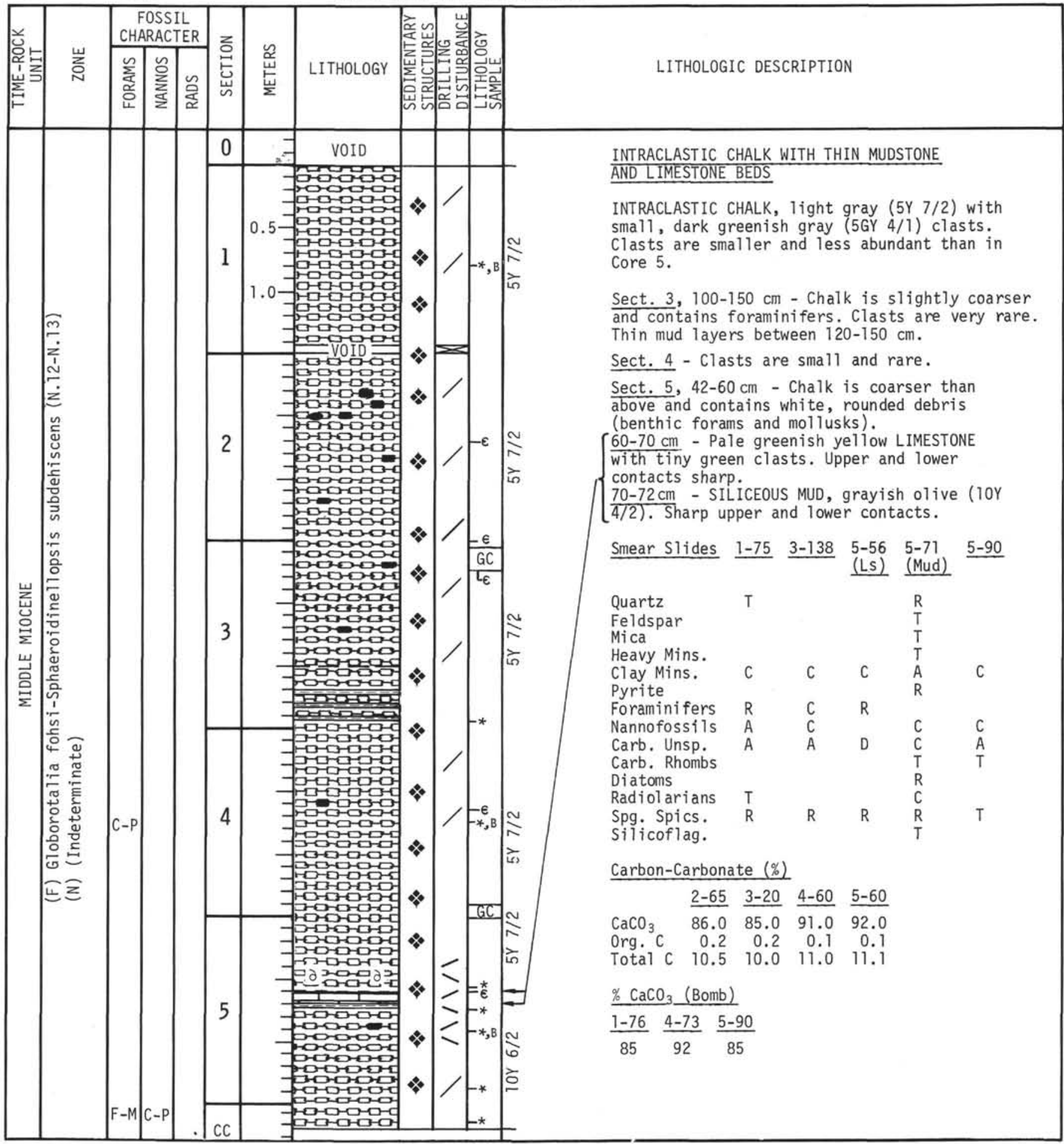


Hole 391A Core 7

Cored Interval: $326.0-335,5 \mathrm{~m}$

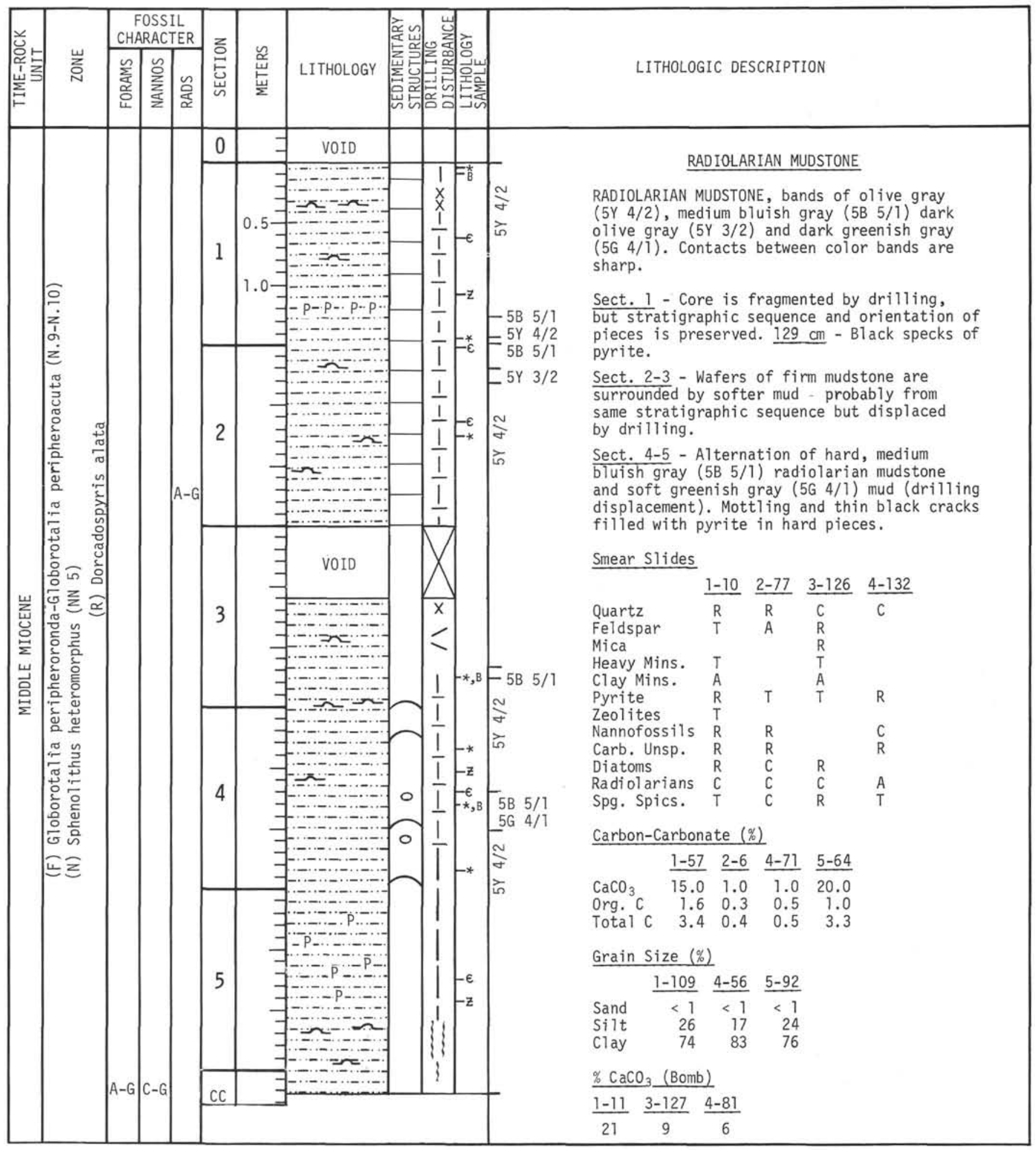




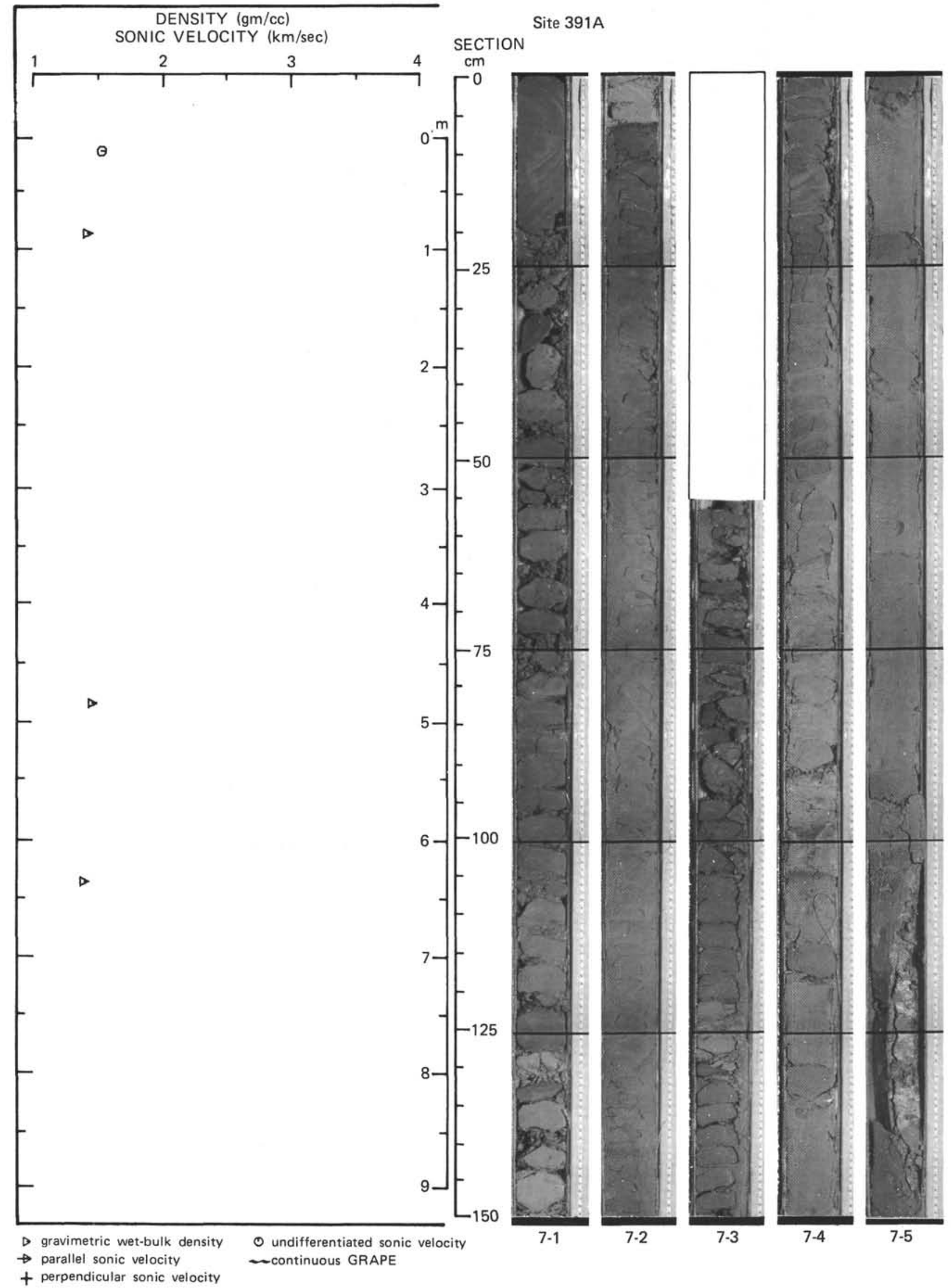




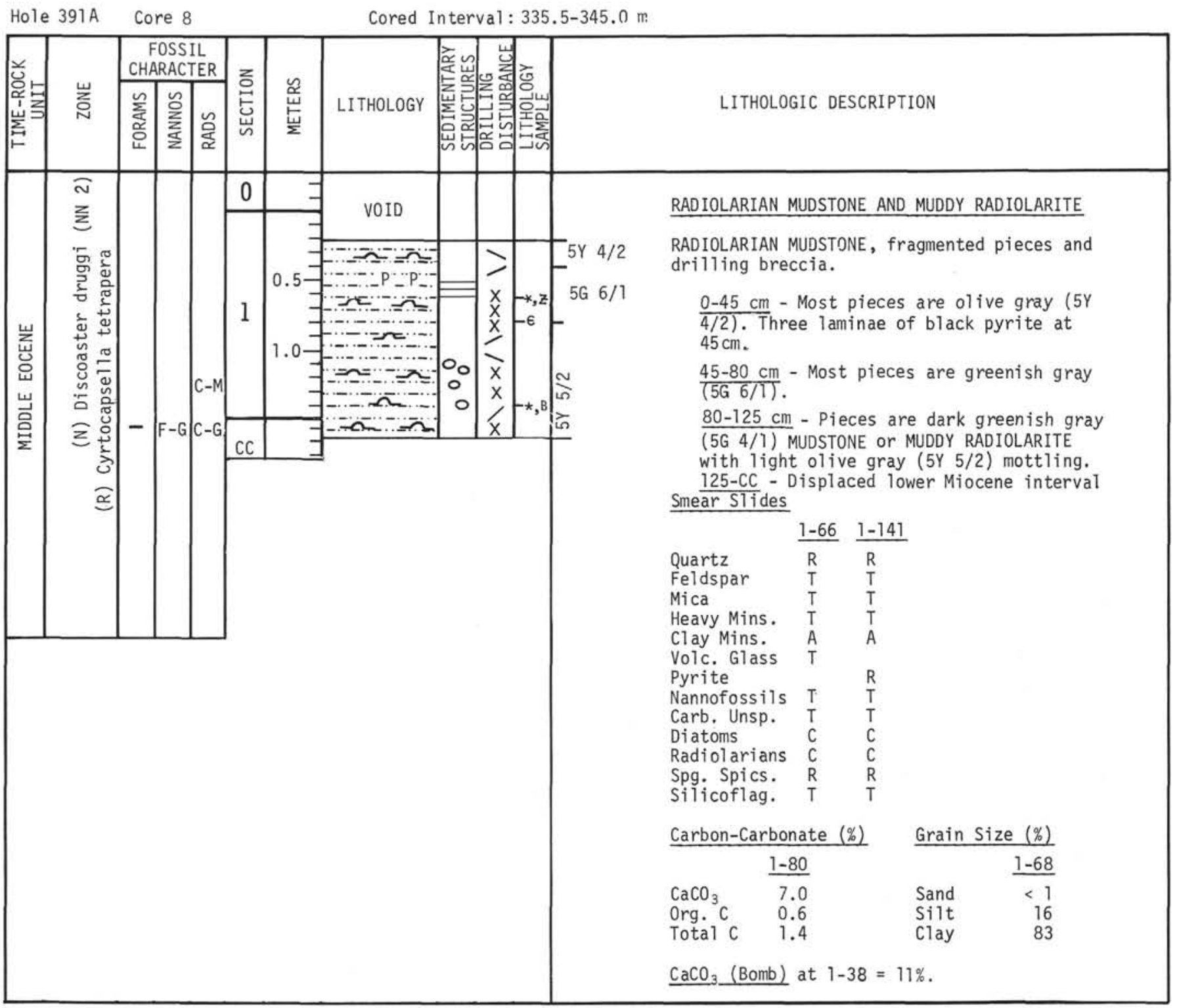




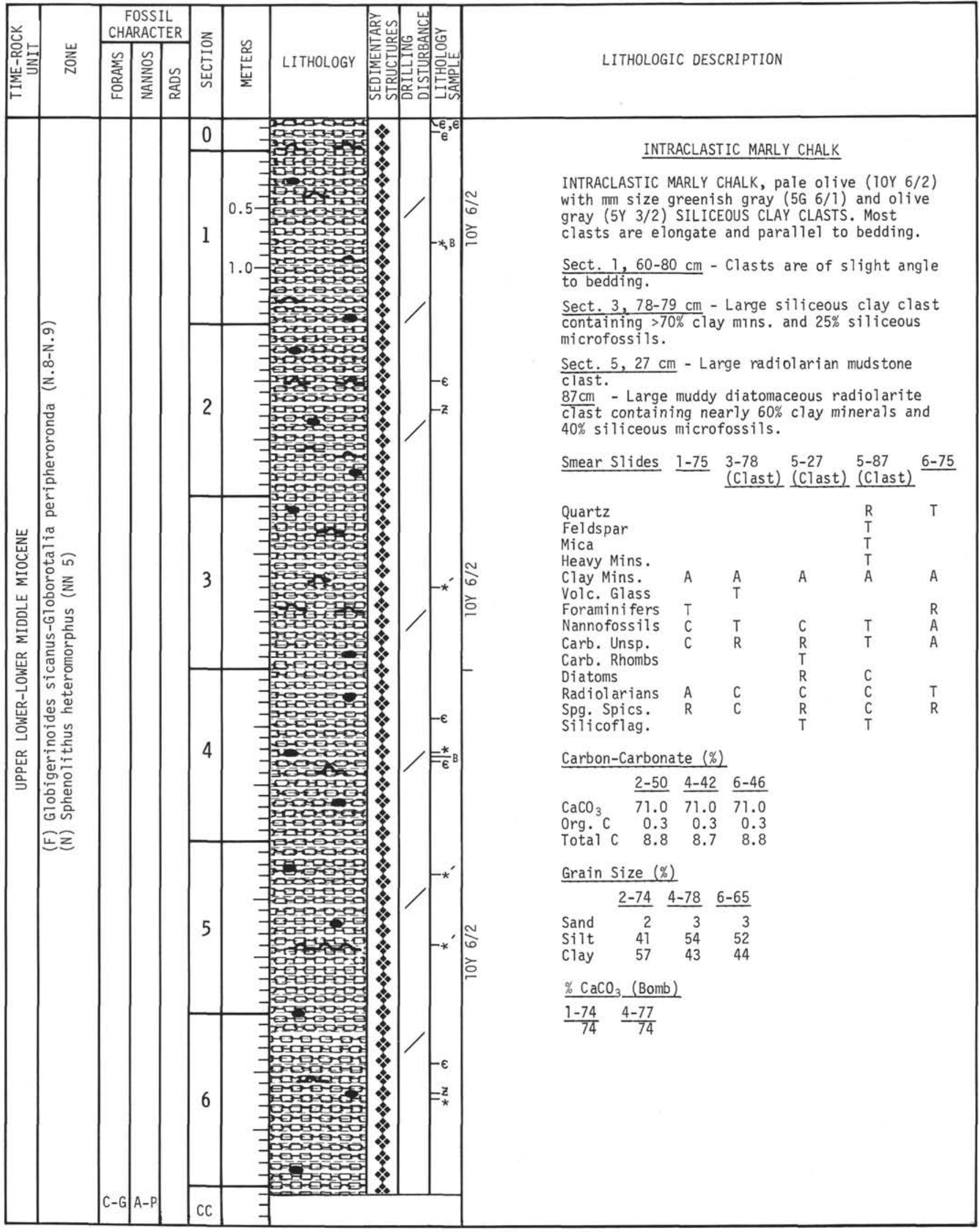




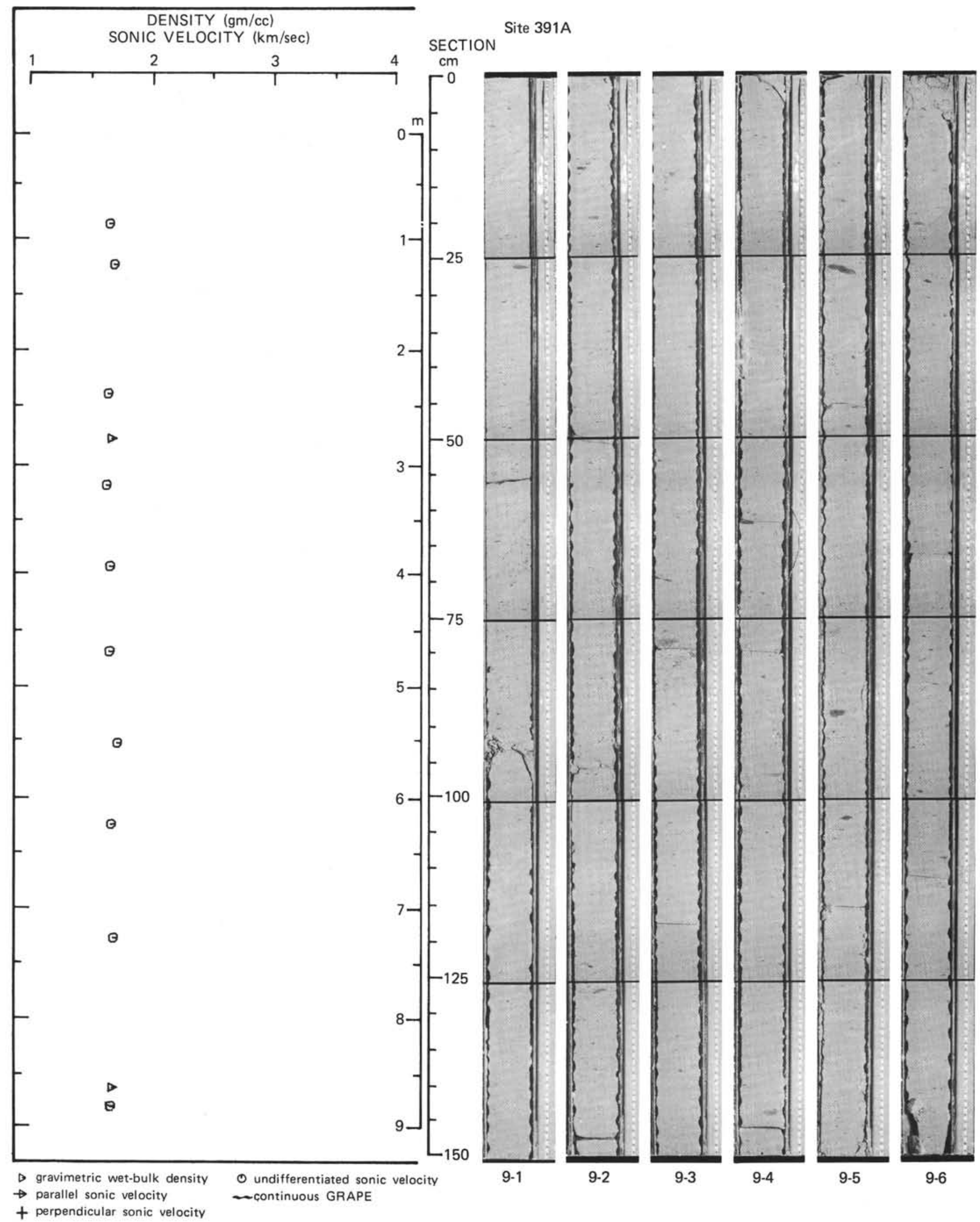




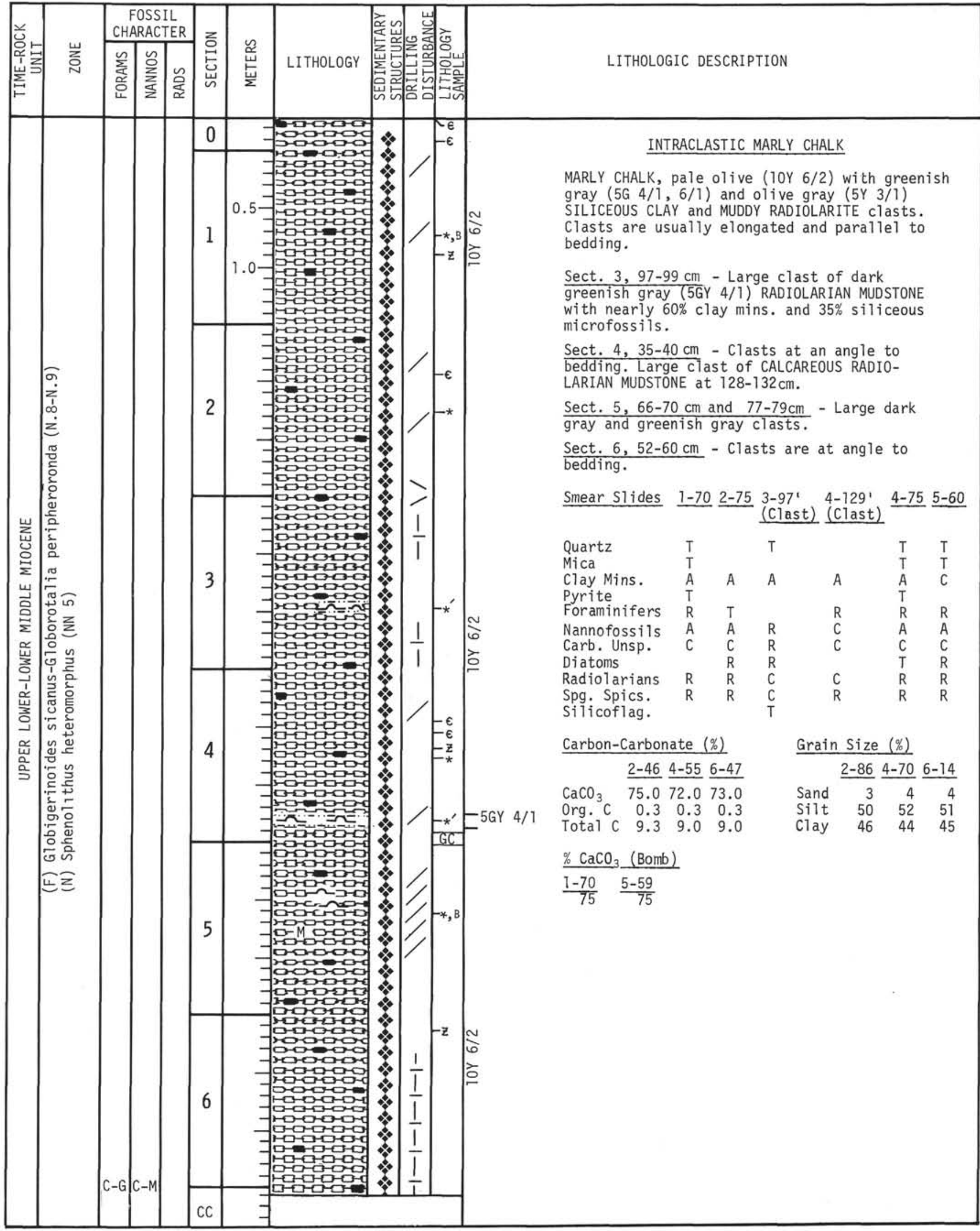




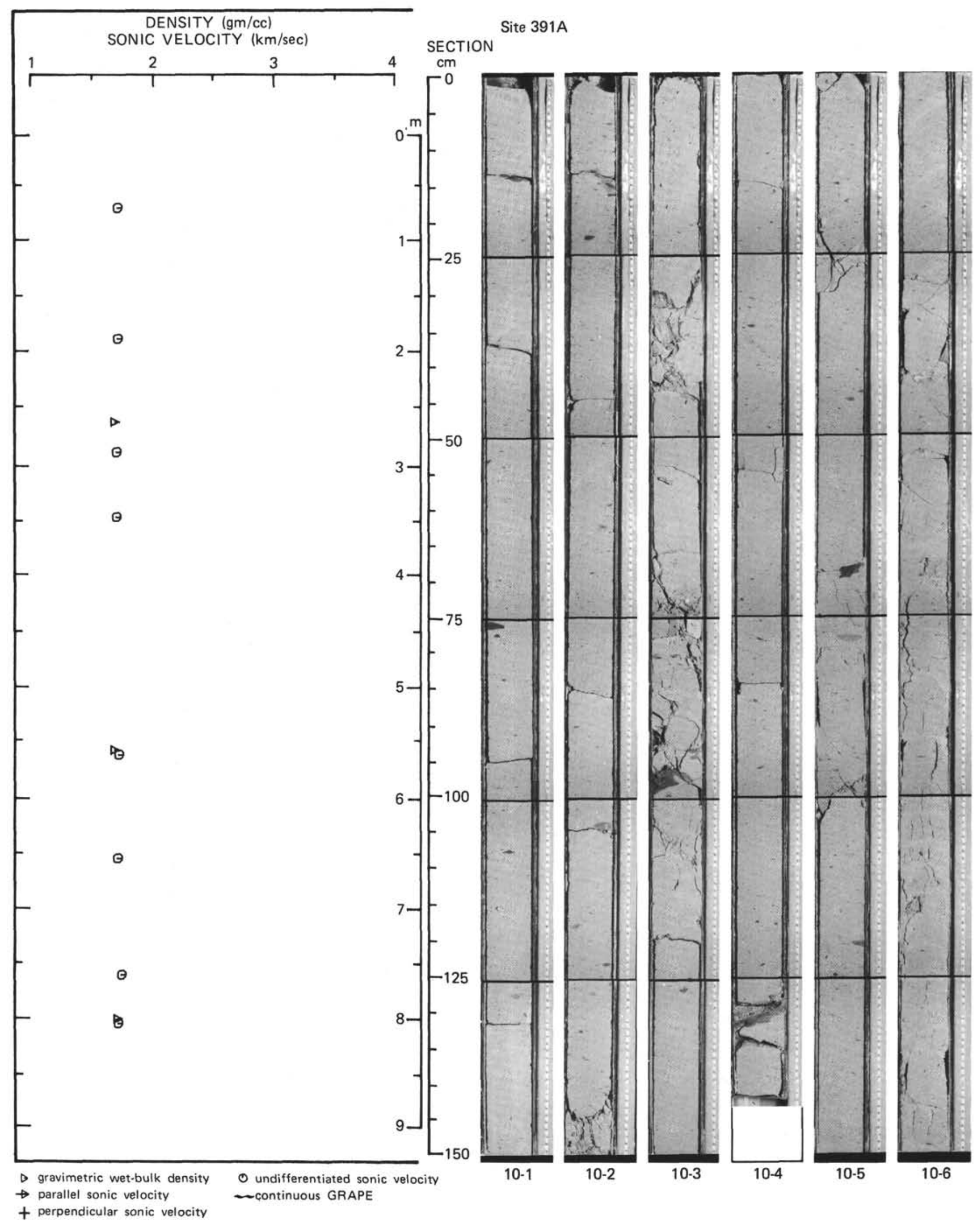




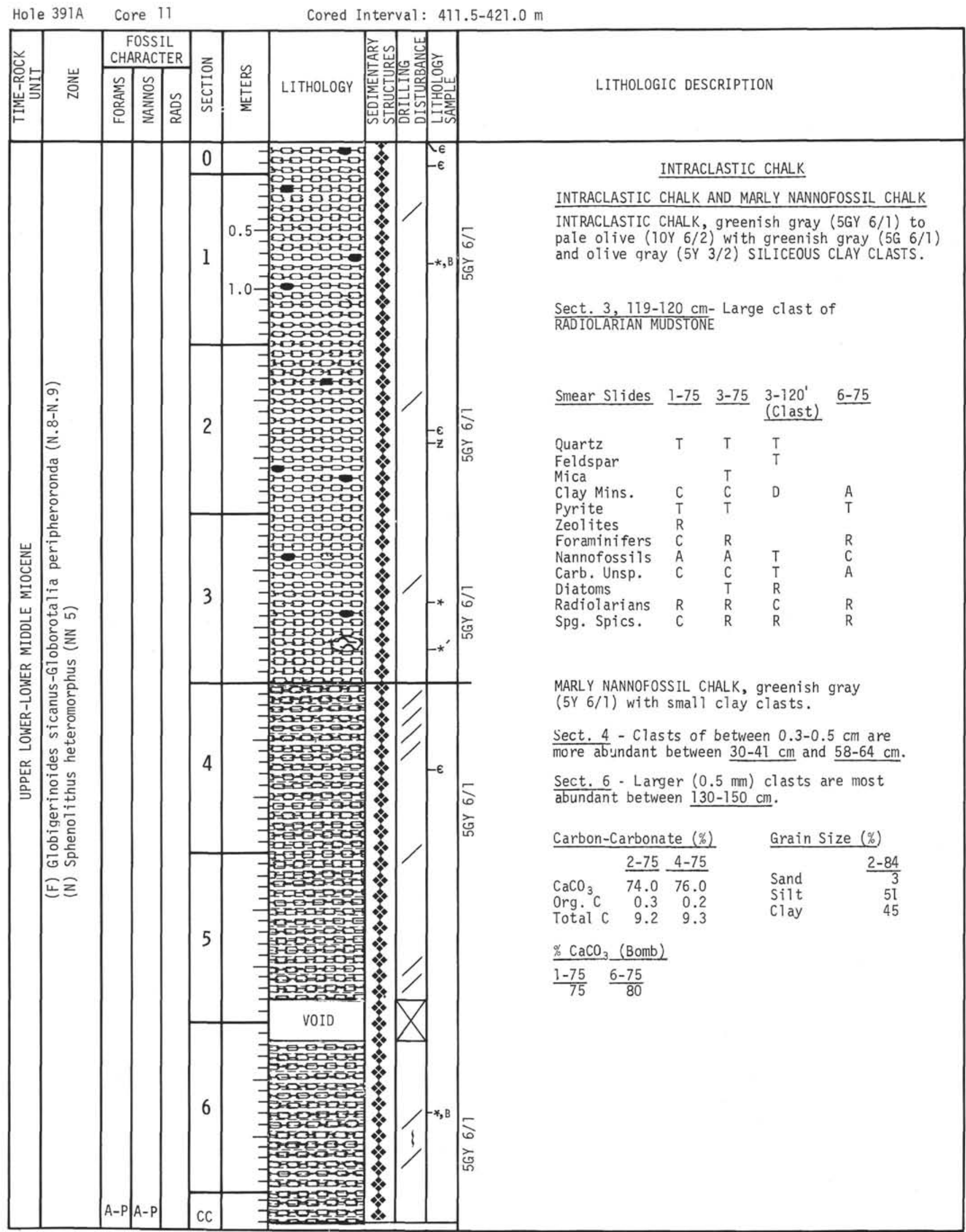




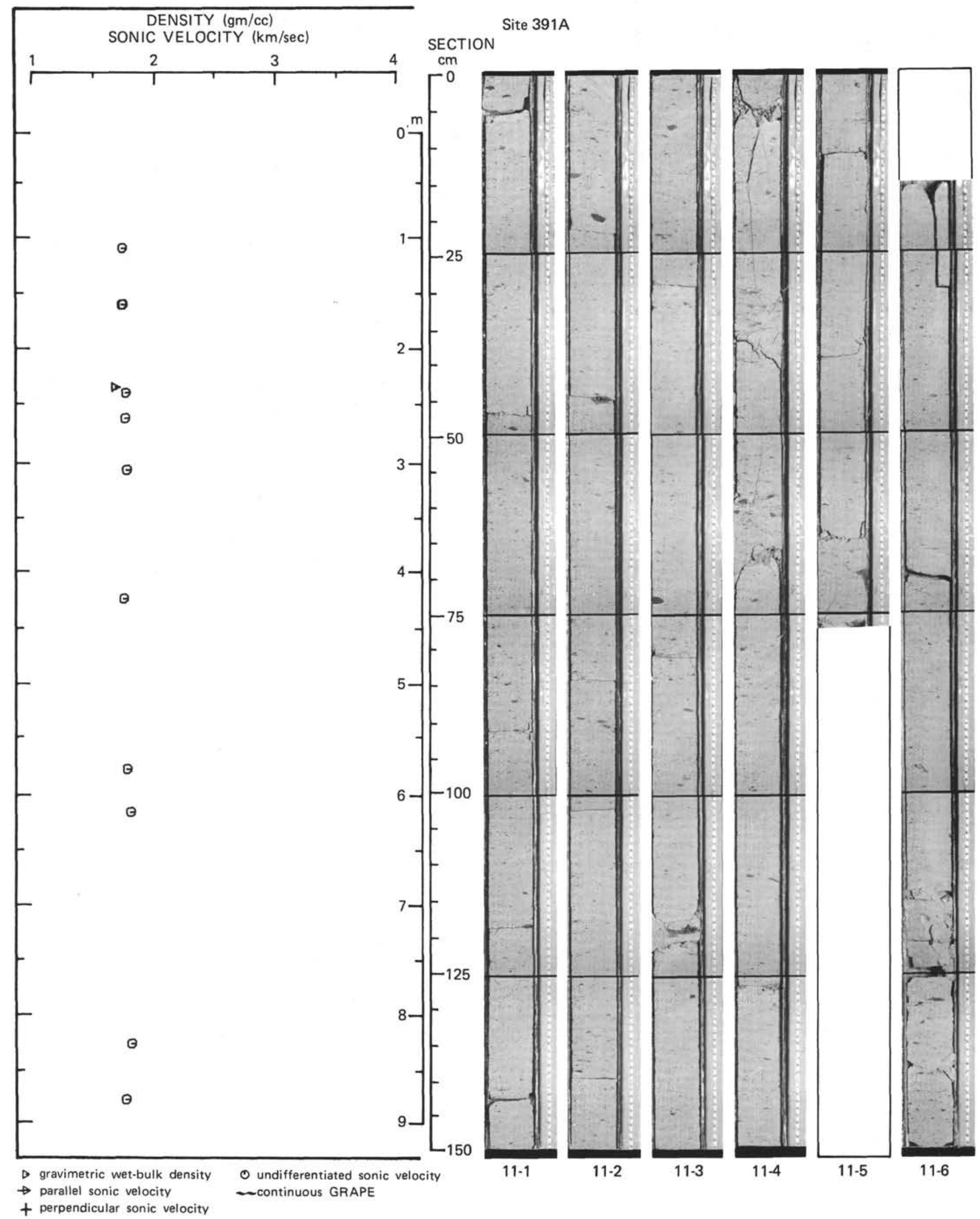




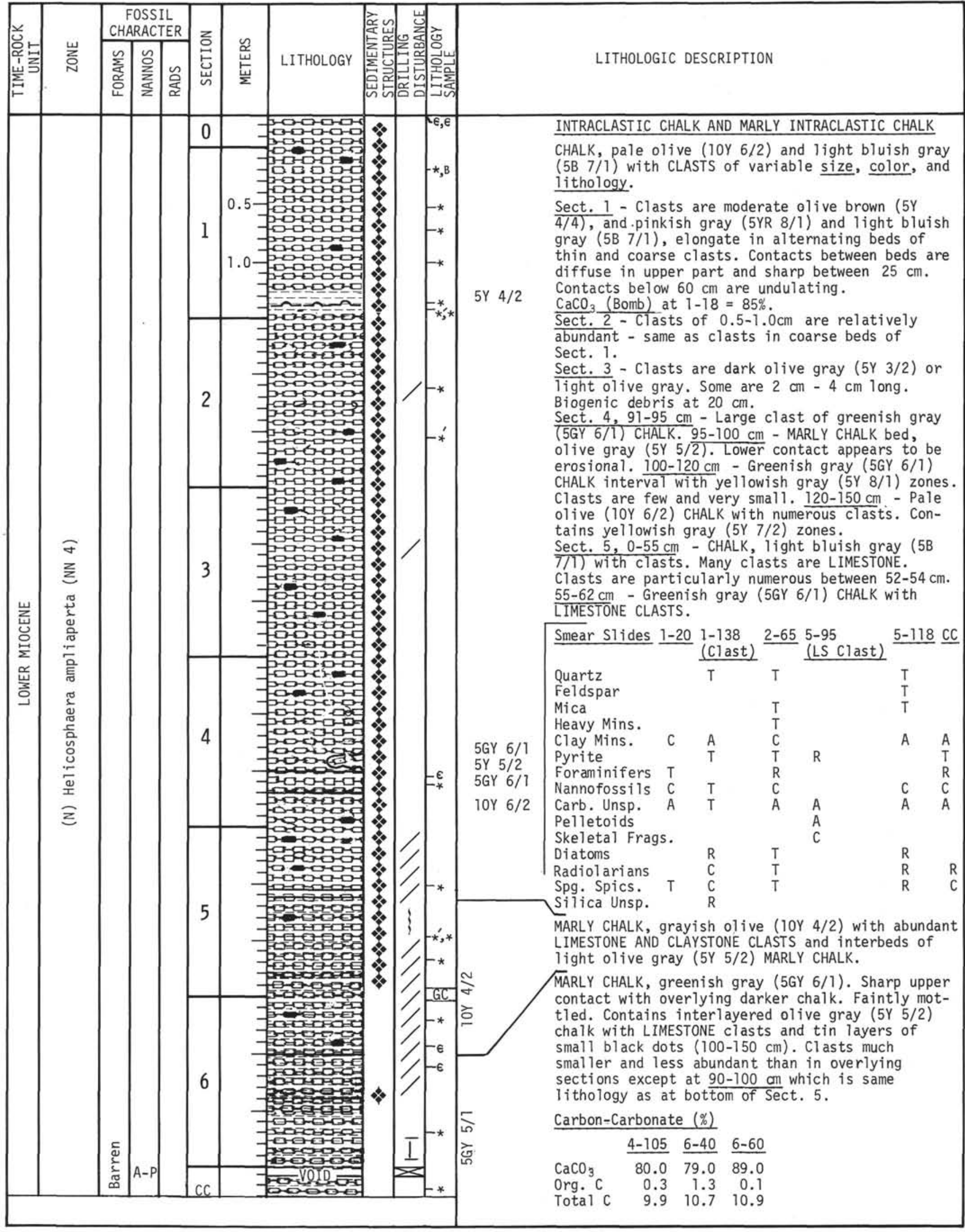




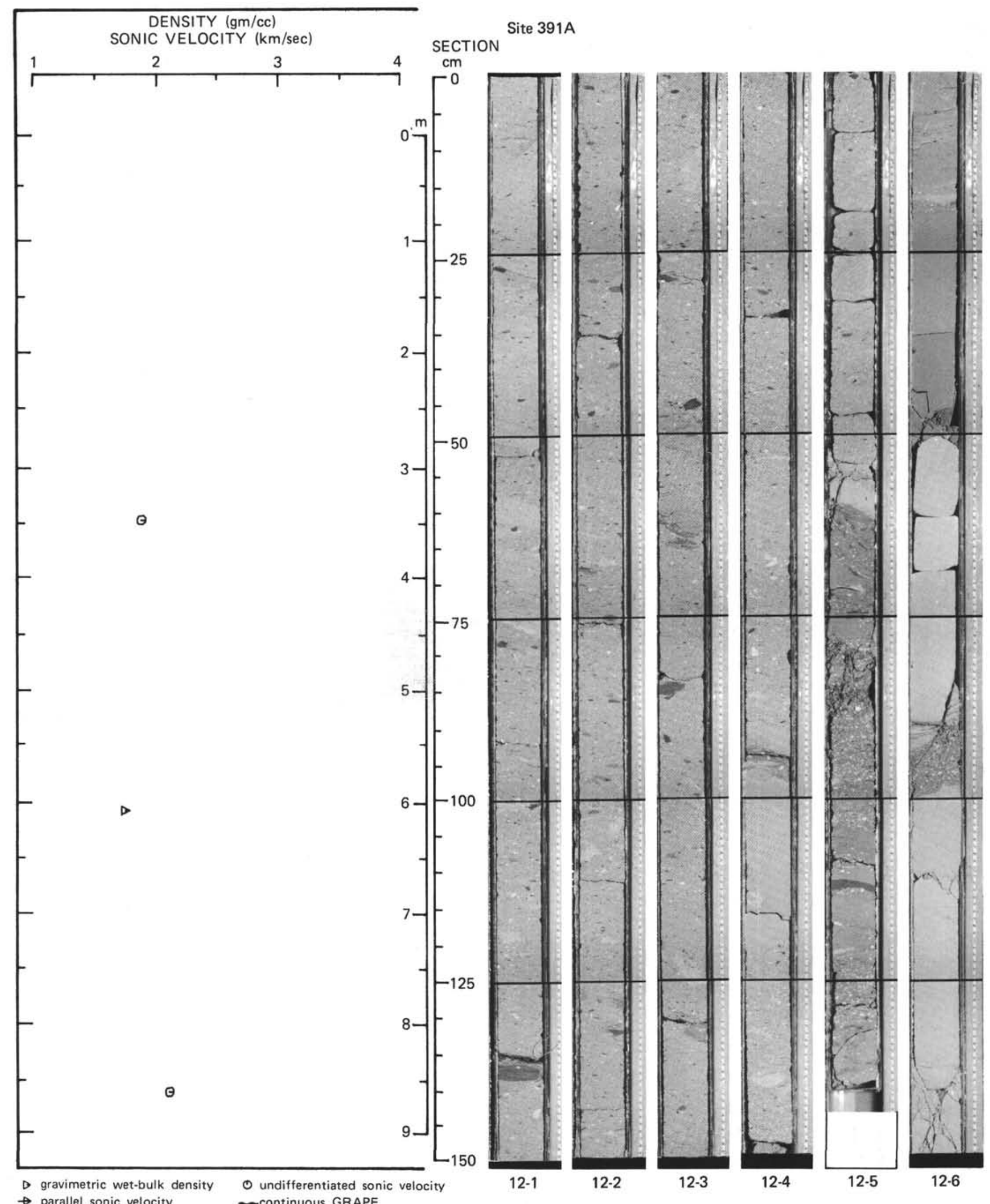




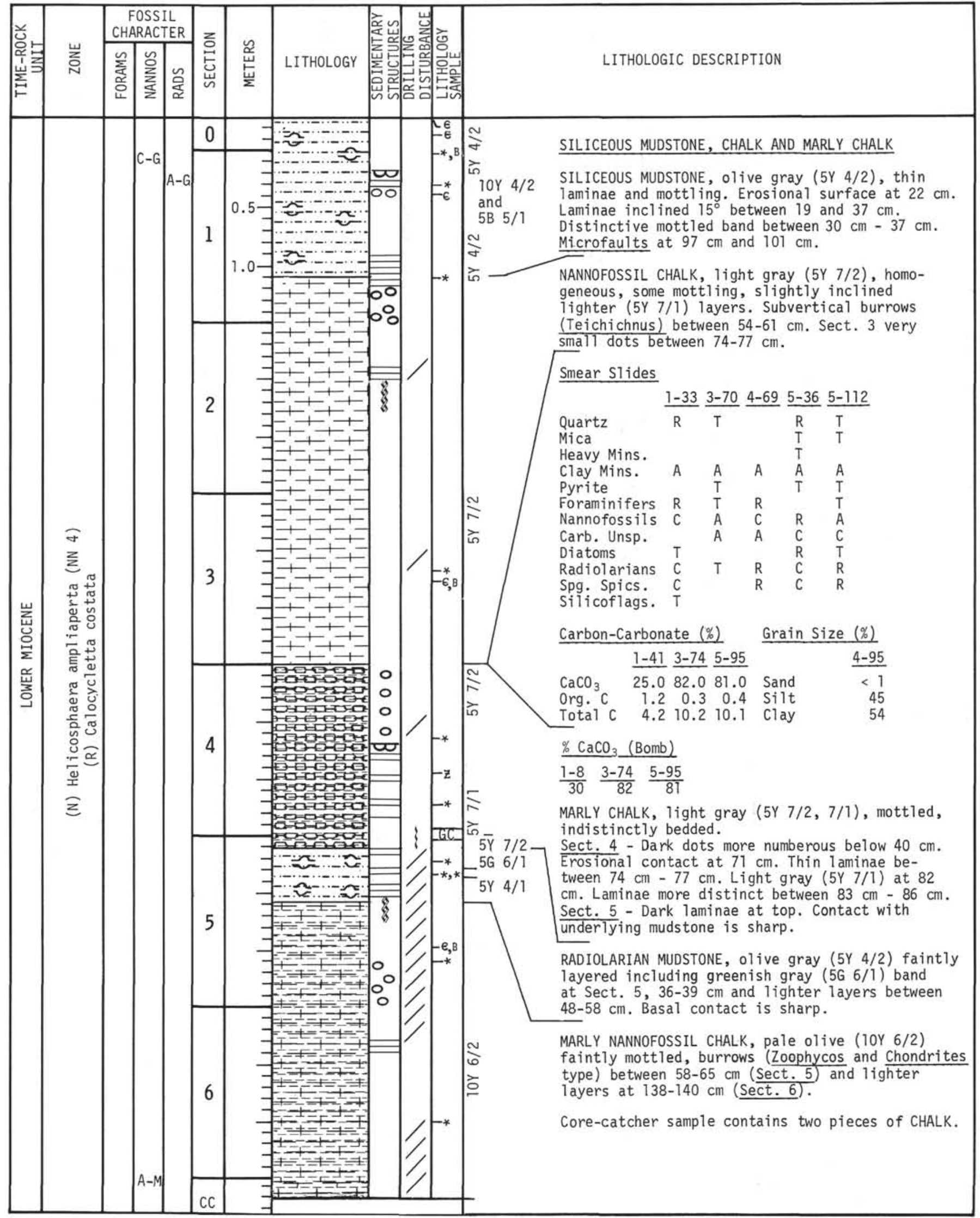




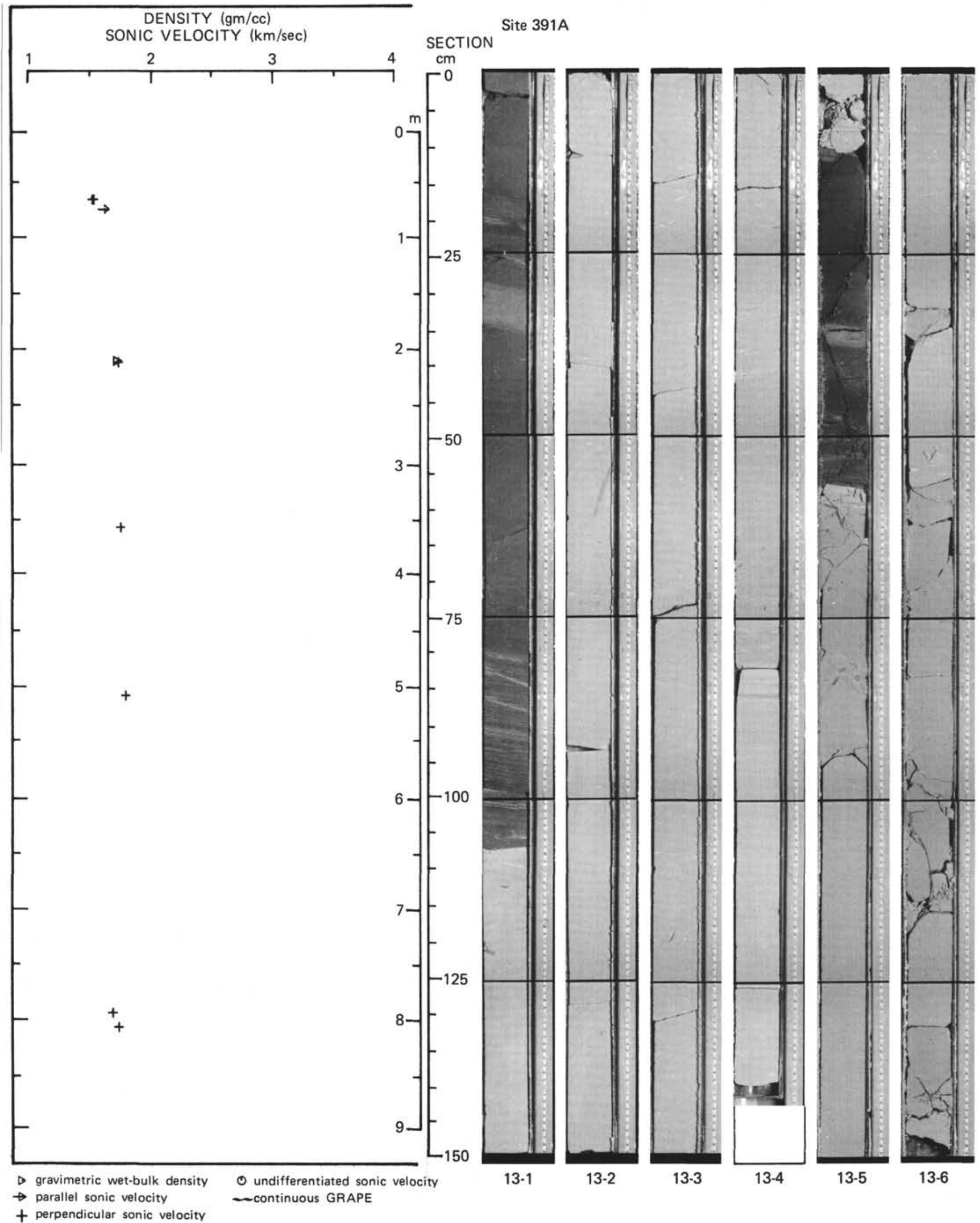


Hole 391A Core $14 \quad$ Cored Interval: $535.0-544.5 \mathrm{~m}$

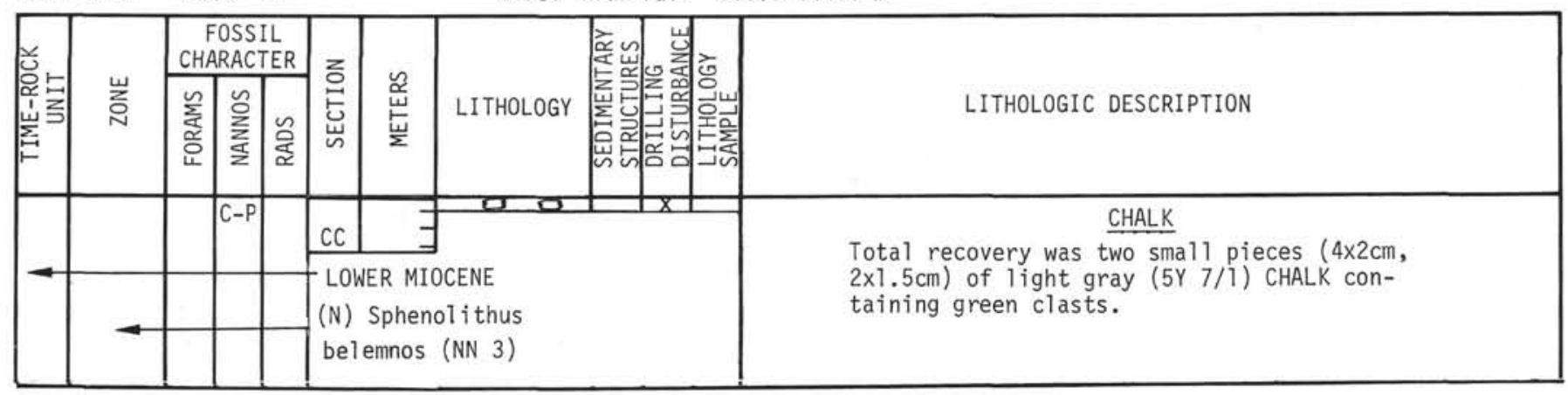

Hole 391A Core $15 \quad$ Cored Interval: $544.5-554.0 \mathrm{~m}$

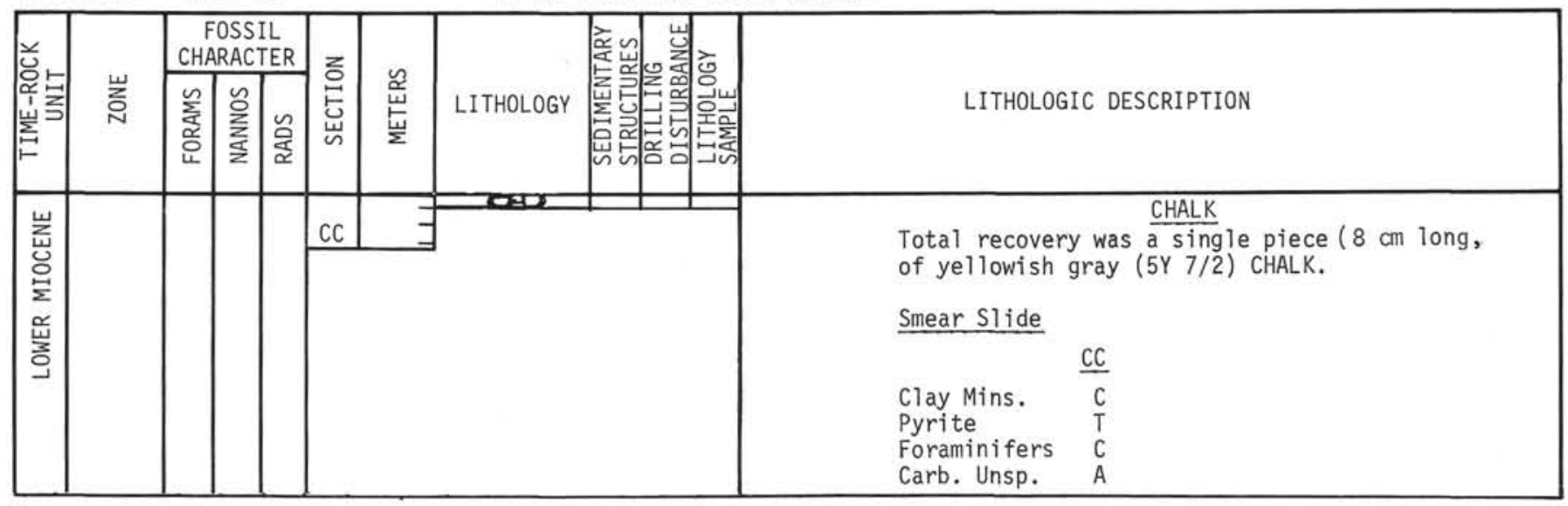

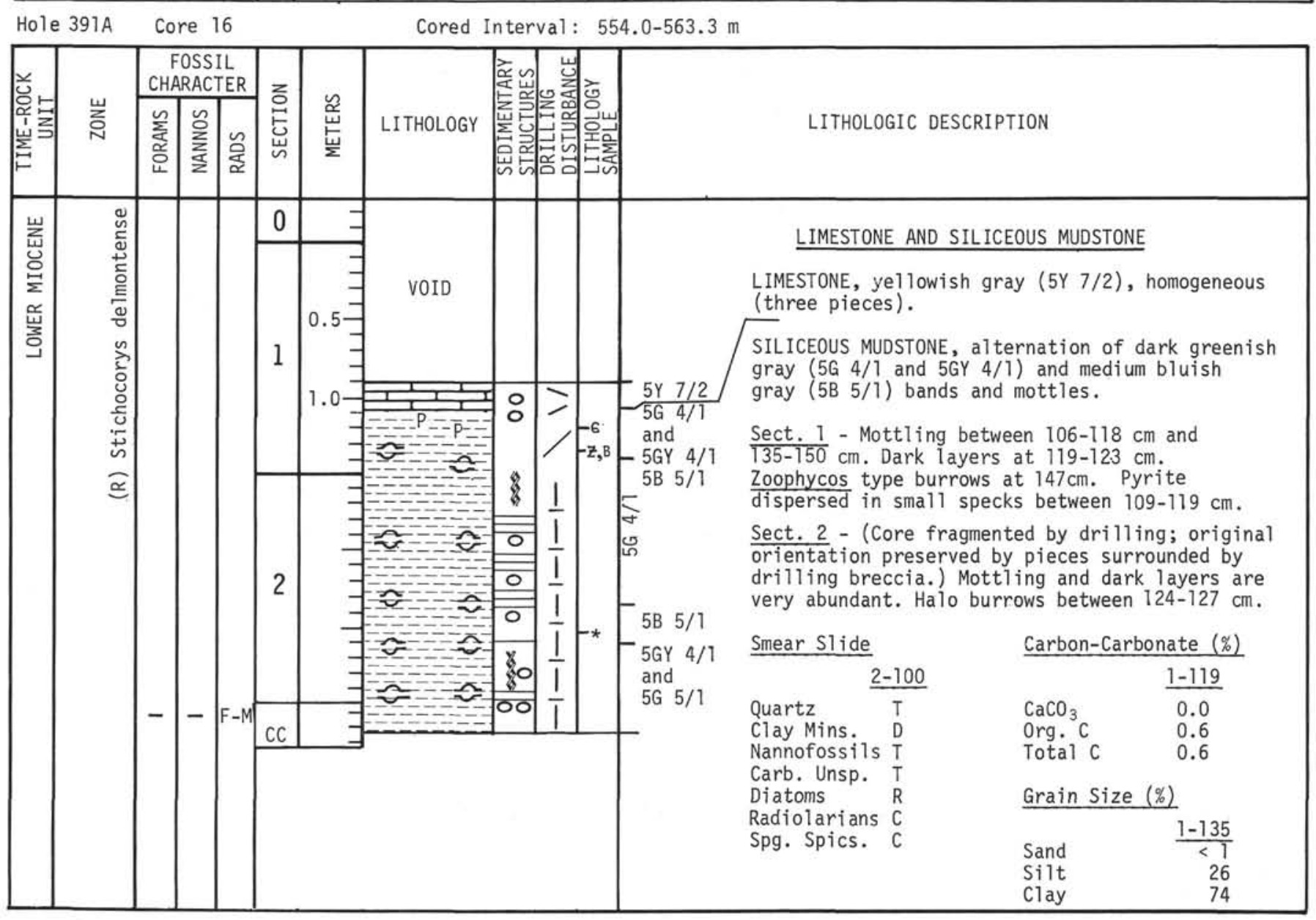




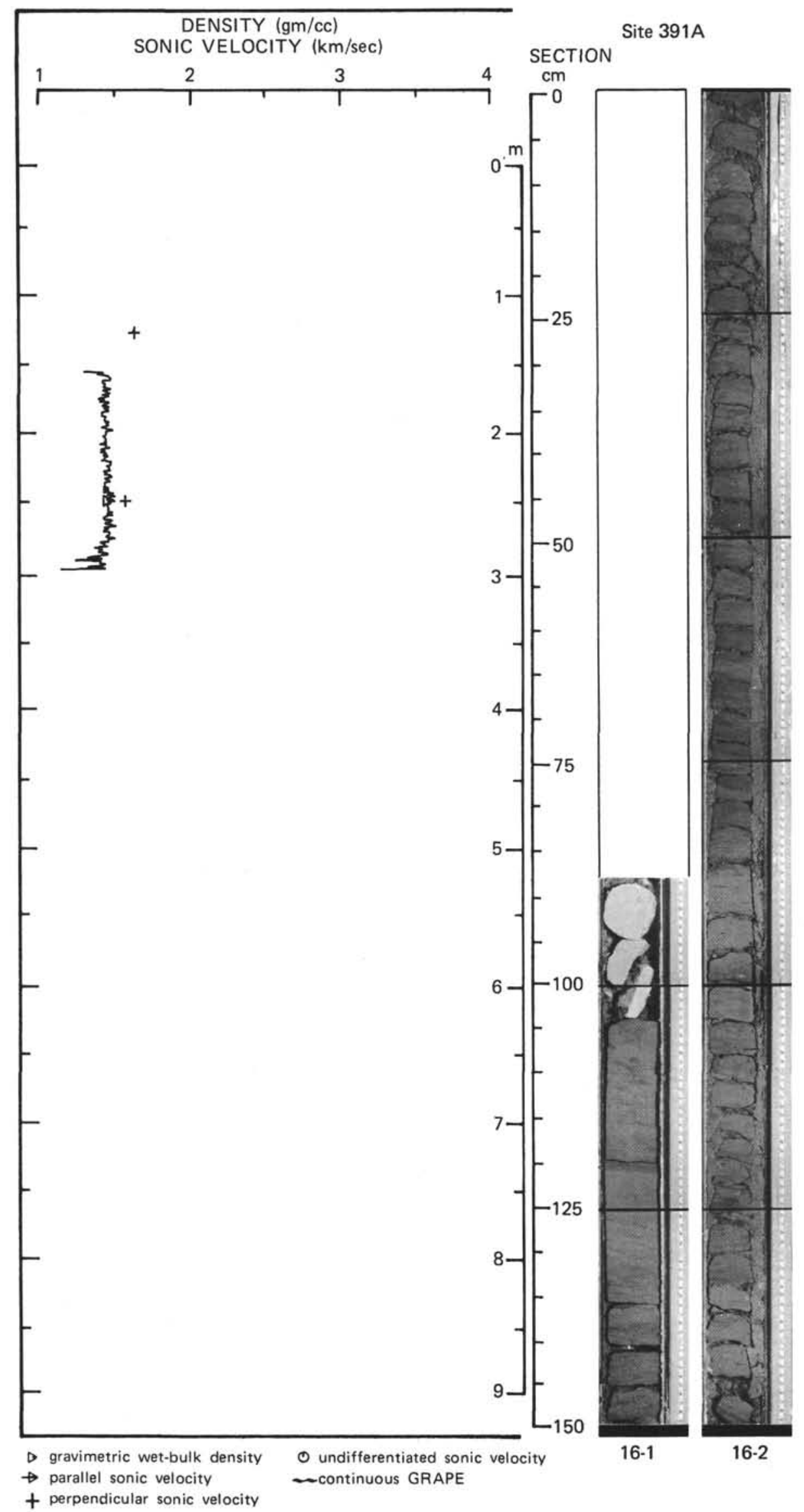


Hole 391A Core 17

Cored Interval: $563.5-573.0 \mathrm{~m}$

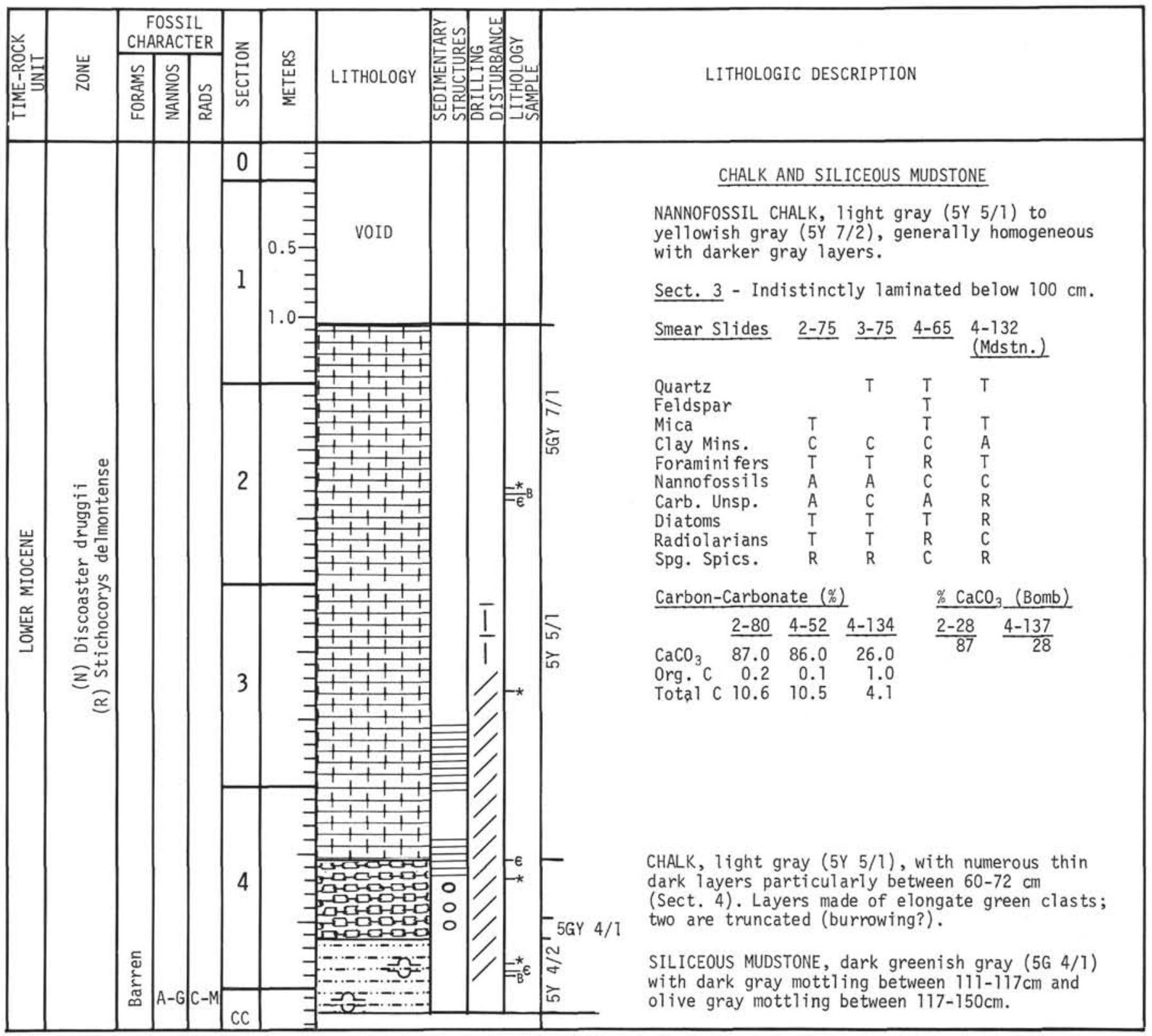

Hole 391A Core 18 Cored Interval: $573.0-582.5 \mathrm{~m}$

\begin{tabular}{|c|c|c|c|c|c|c|c|c|c|}
\hline \multirow{2}{*}{ 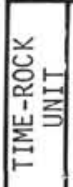 } & \multirow[b]{2}{*}{ 岂 } & \multicolumn{3}{|c|}{$\begin{array}{c}\text { FOSSIL } \\
\text { CHARACTER } \\
\end{array}$} & \multirow{2}{*}{ 方 } & \multirow[b]{2}{*}{ 岂 } & \multirow[b]{2}{*}{ LITHOLOGY } & \multirow{2}{*}{ 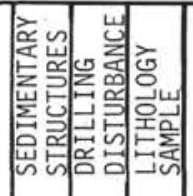 } & \multirow[b]{2}{*}{ LITHOLOGIC DESCRIPTION } \\
\hline & & 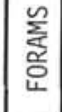 & 兑 & 兑 & & & & & \\
\hline 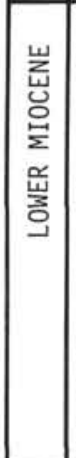 & 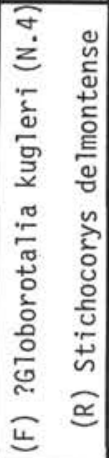 & R-P & - & $F-M$ & $\mathrm{CC}$ & & 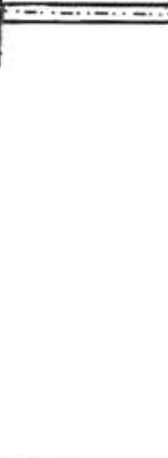 & $2 x$ & $\begin{array}{l}\text { Motal recovery consisted of dark greenish gray } \\
(5 G Y 4 / 1) \text { MUDSTONE mixed with gray }(5 Y 5 / 1) \\
\text { MUDSTONE. }\end{array}$ \\
\hline
\end{tabular}




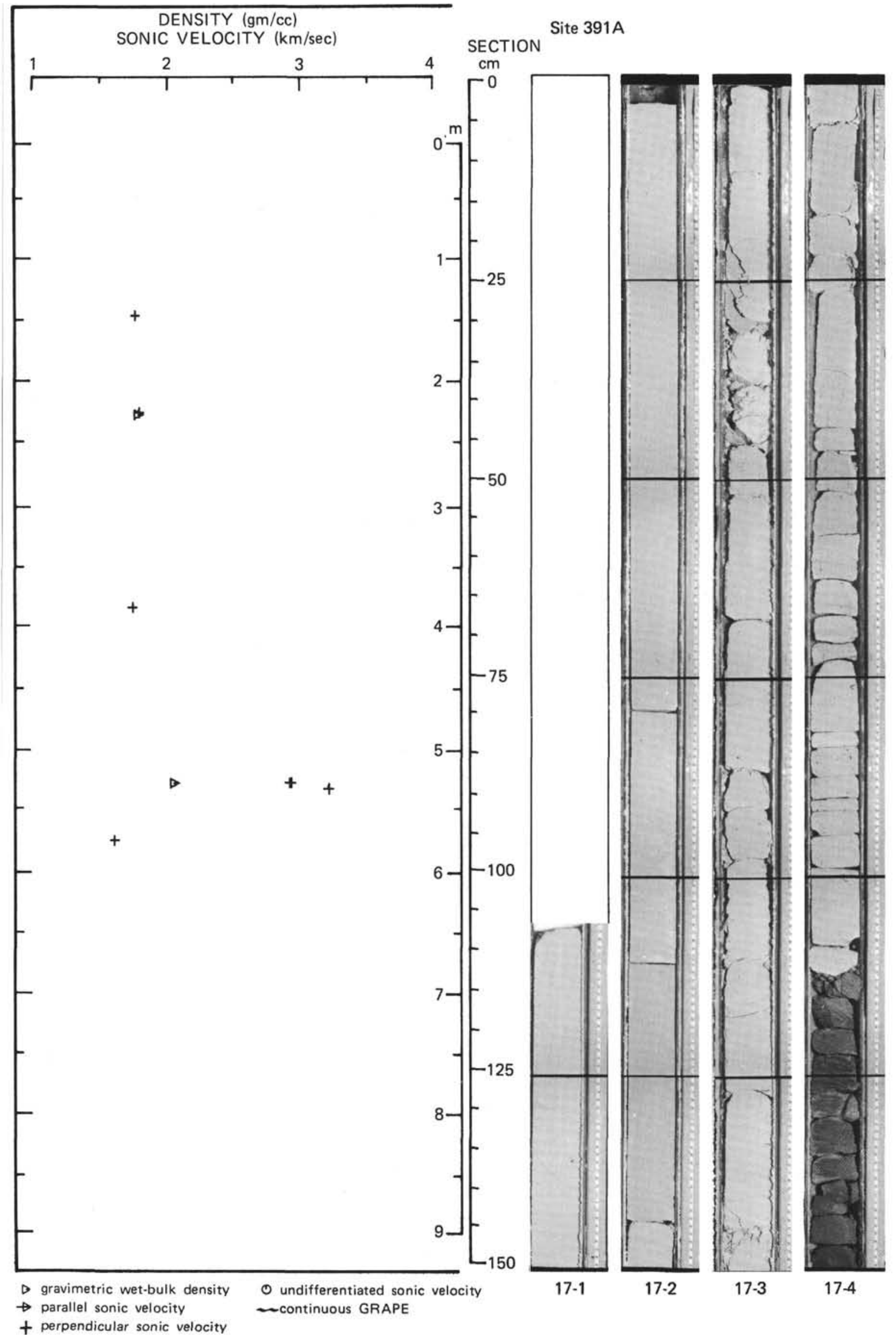




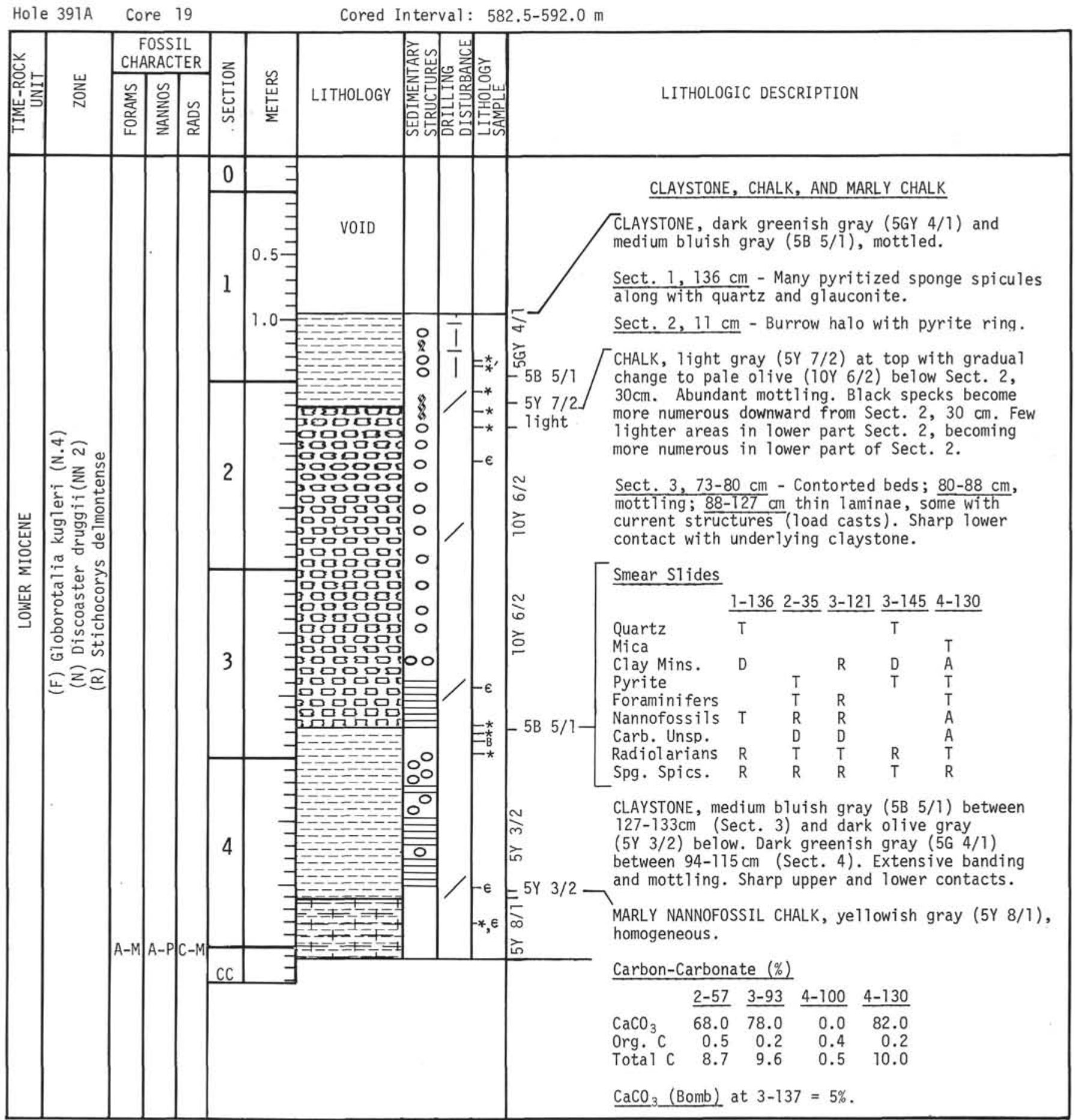




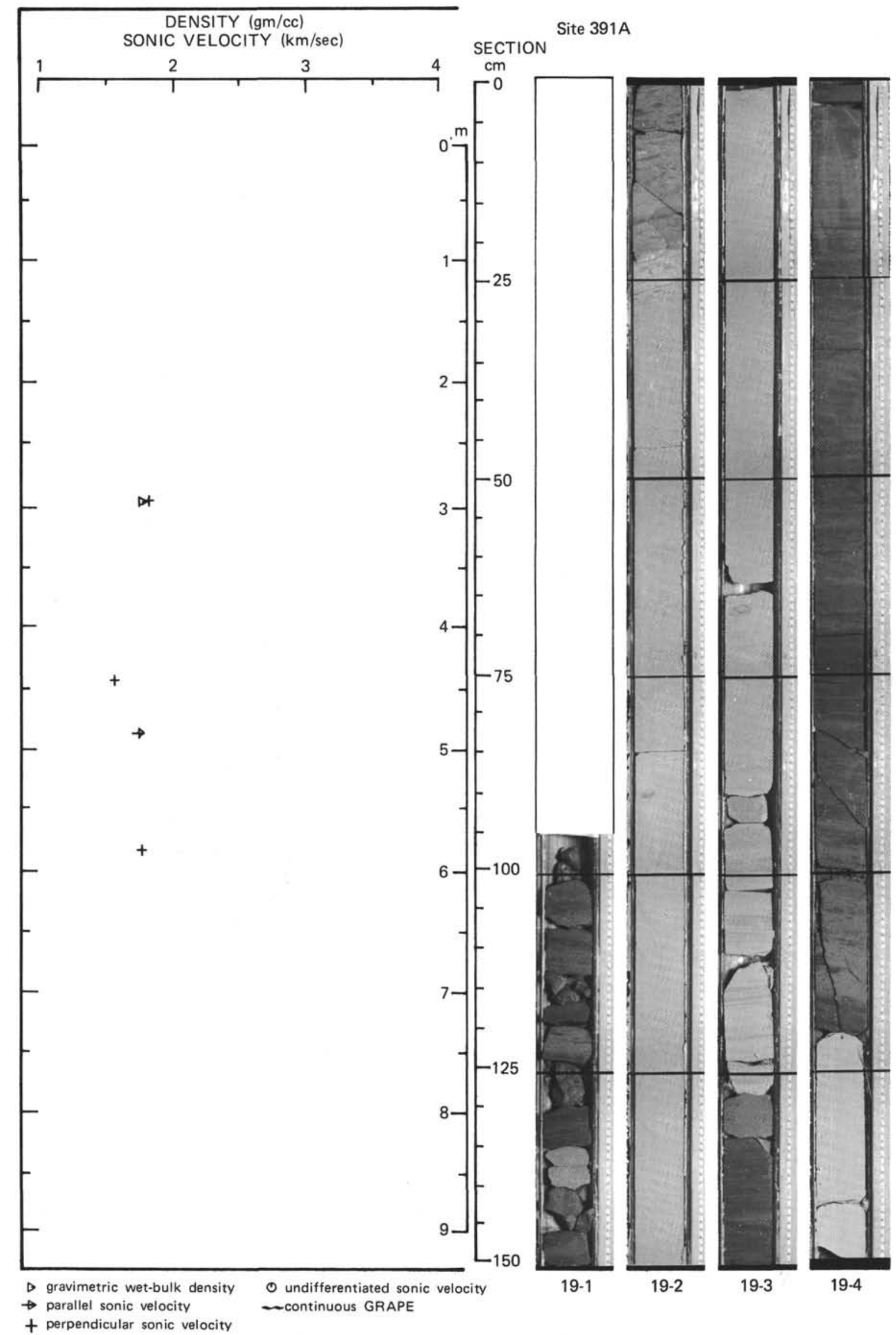




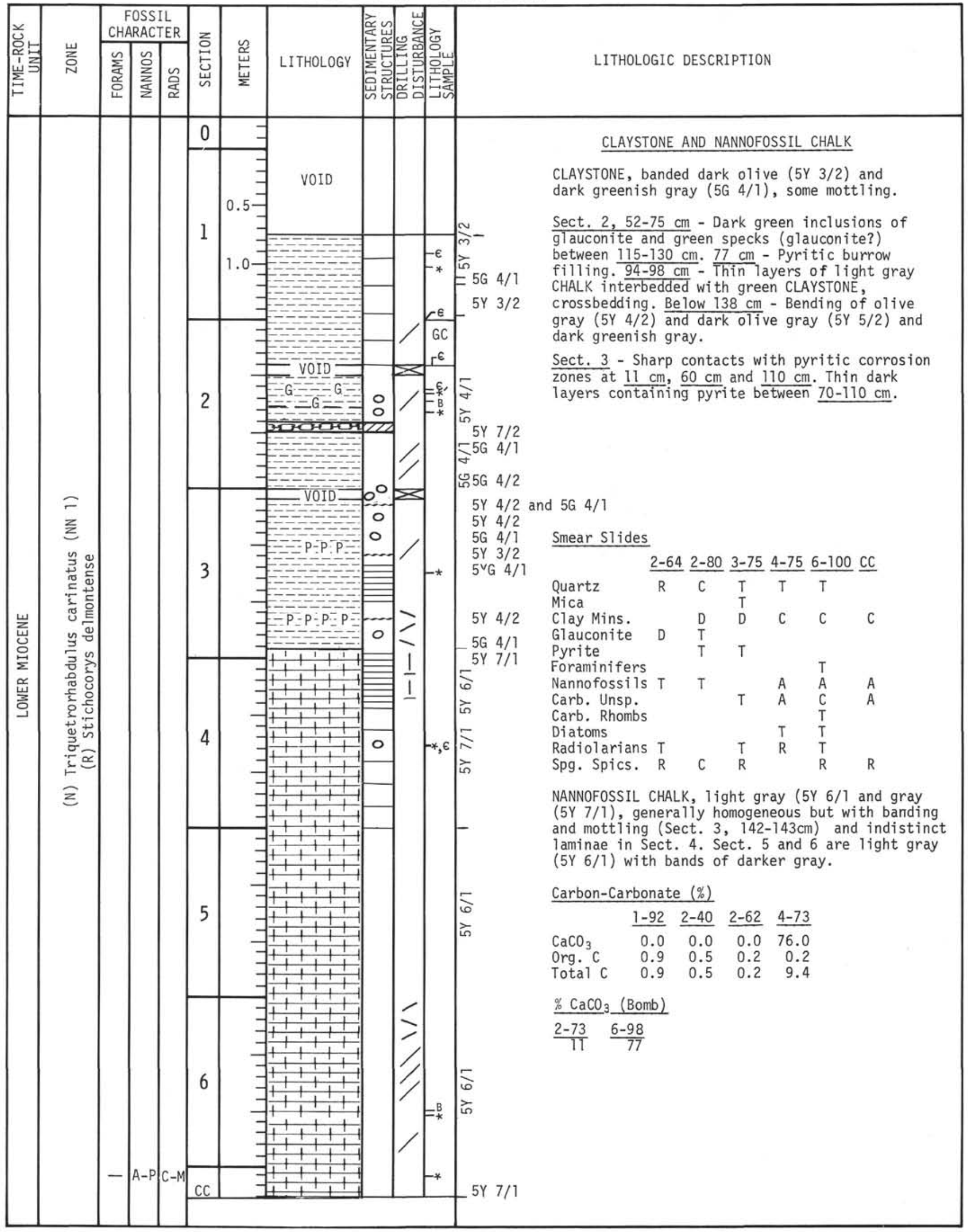




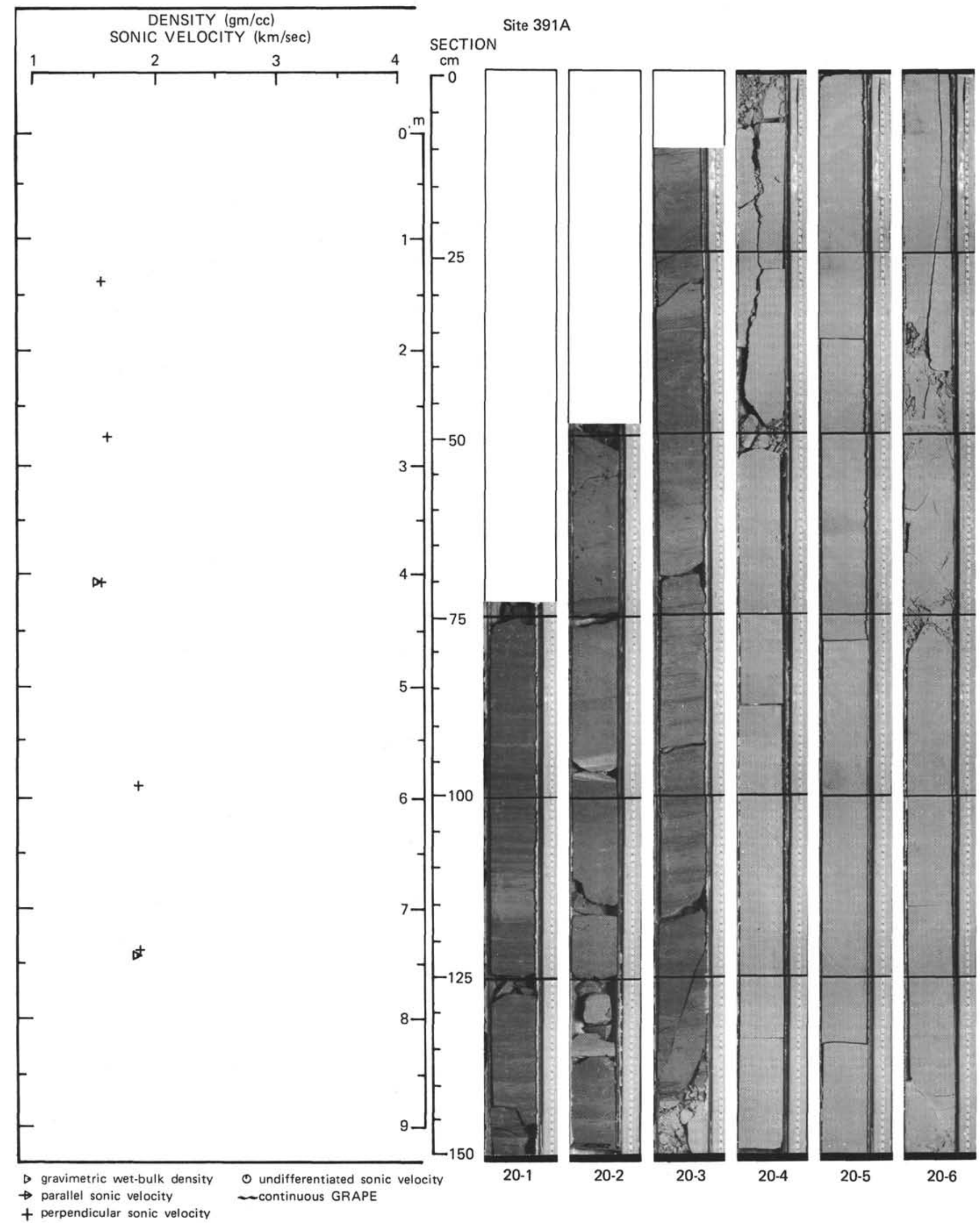


Hole 391A Core 21

Cored Interval: 649.0-658.5 m

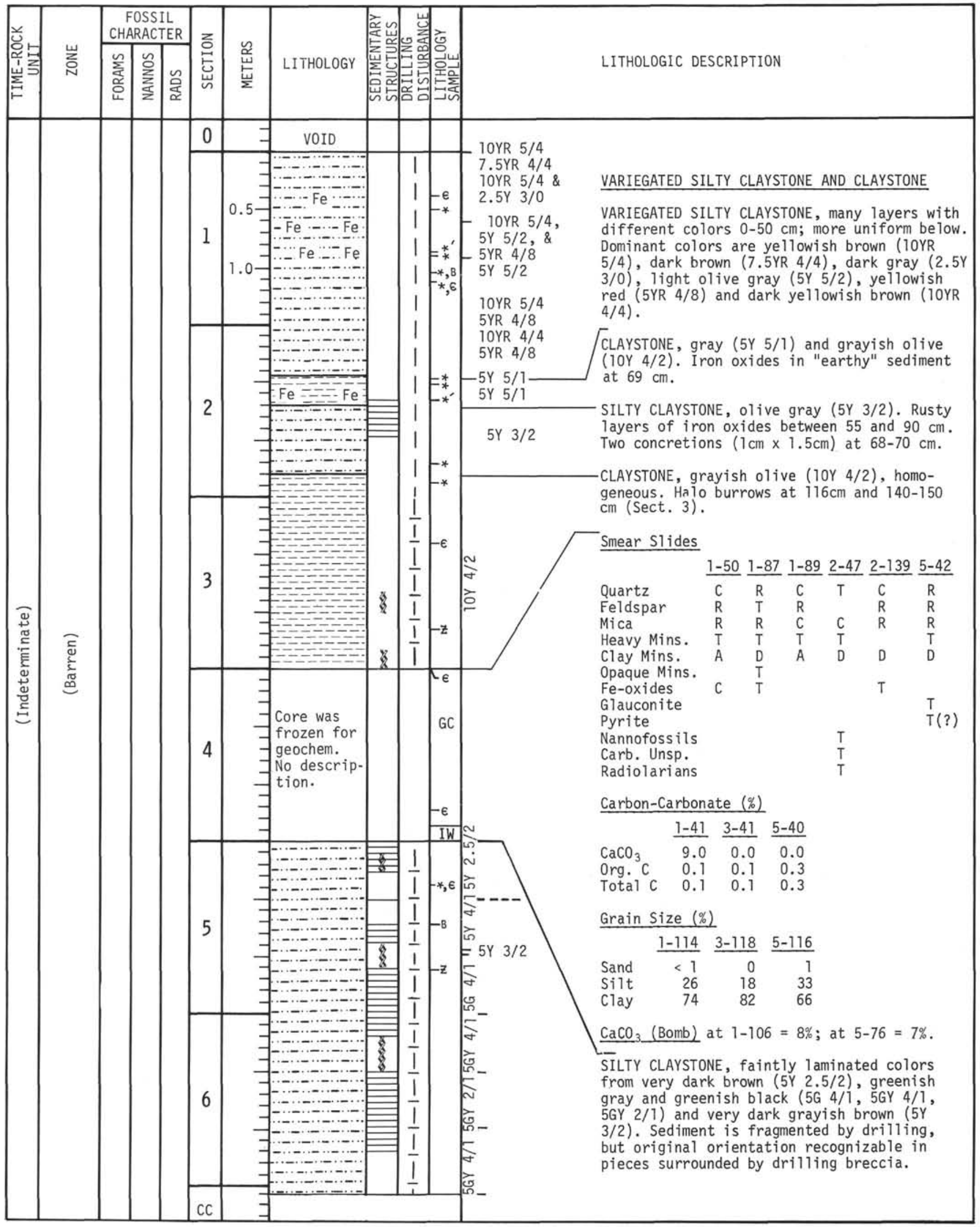




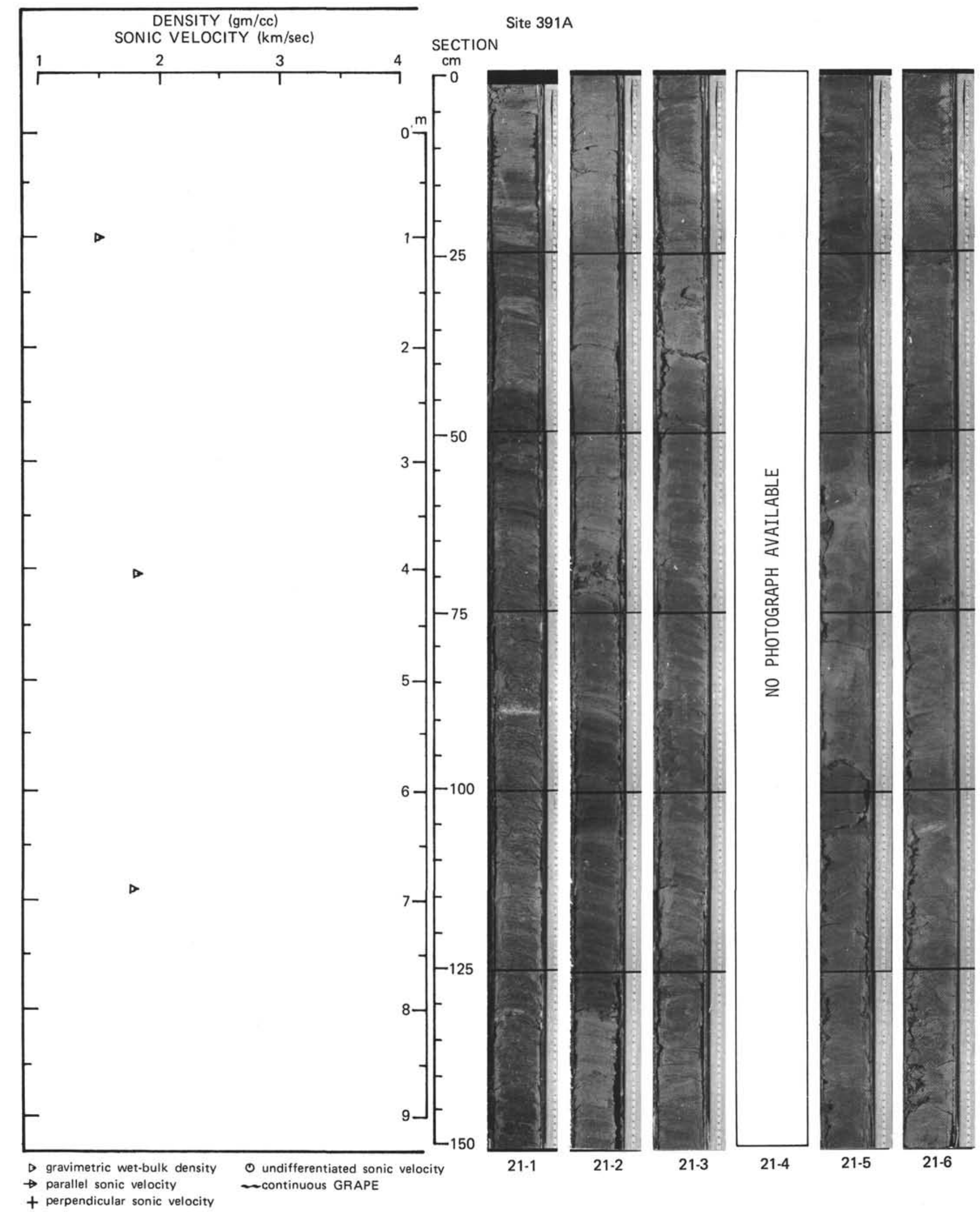


Hole 391B Core 1*

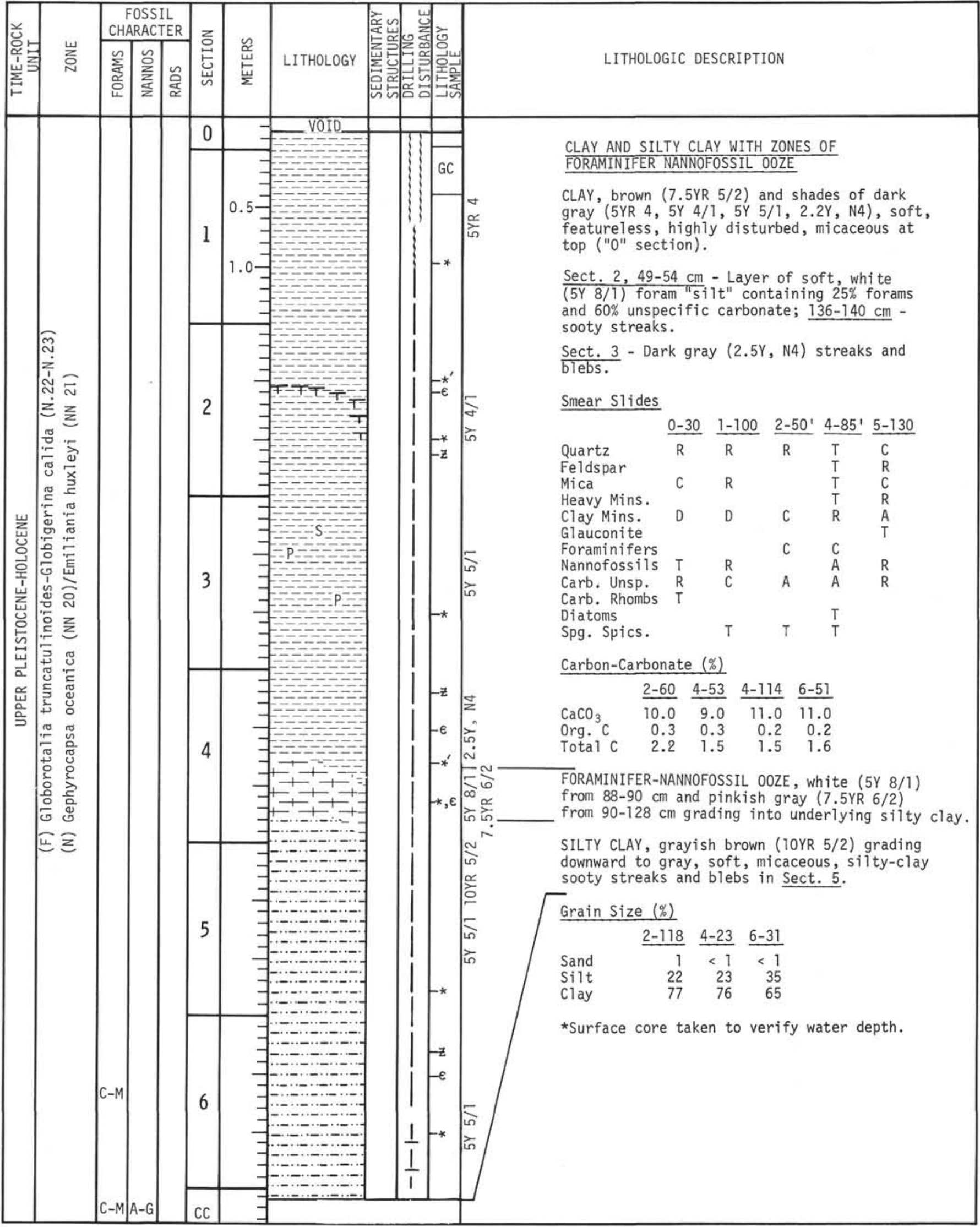




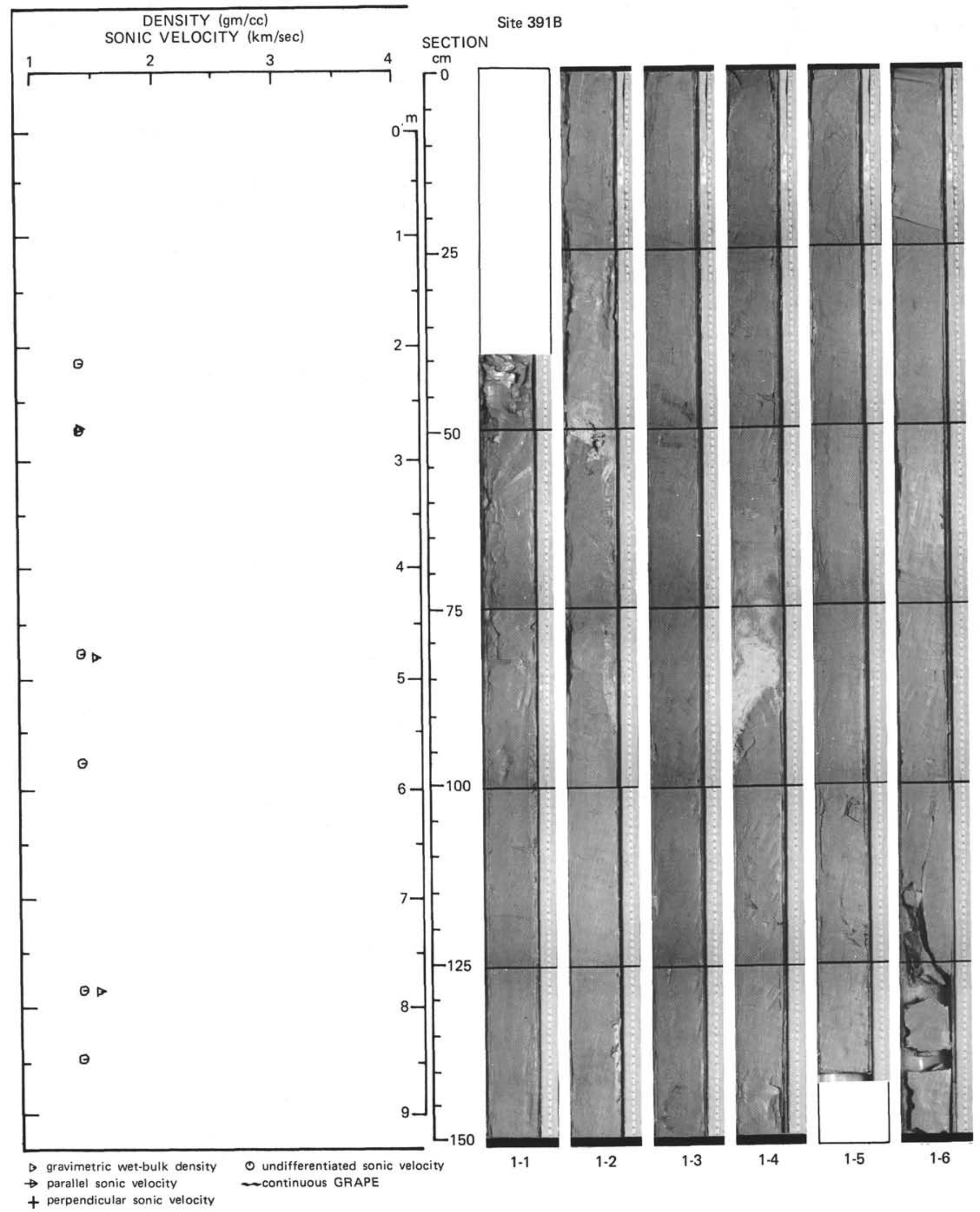




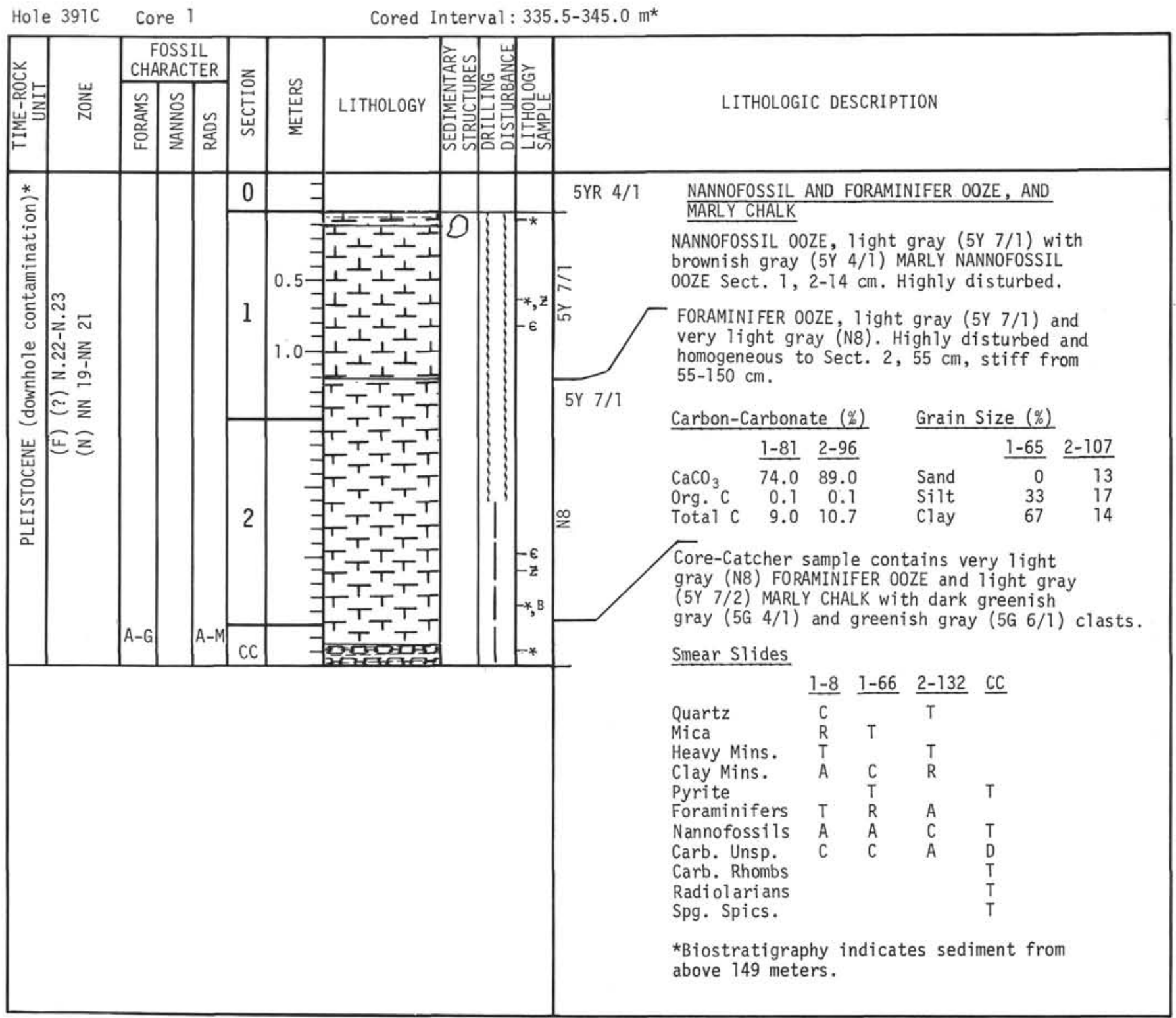




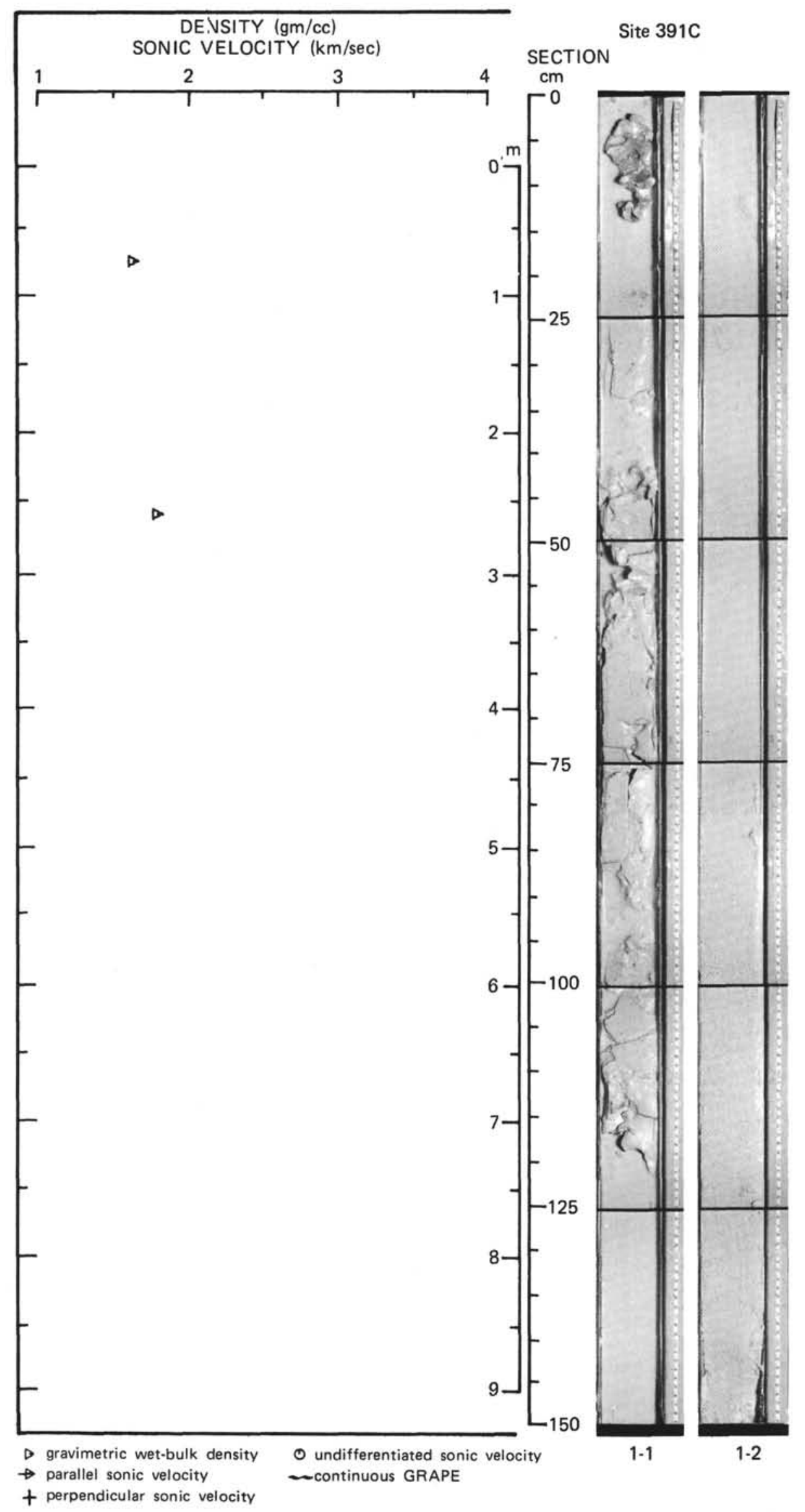




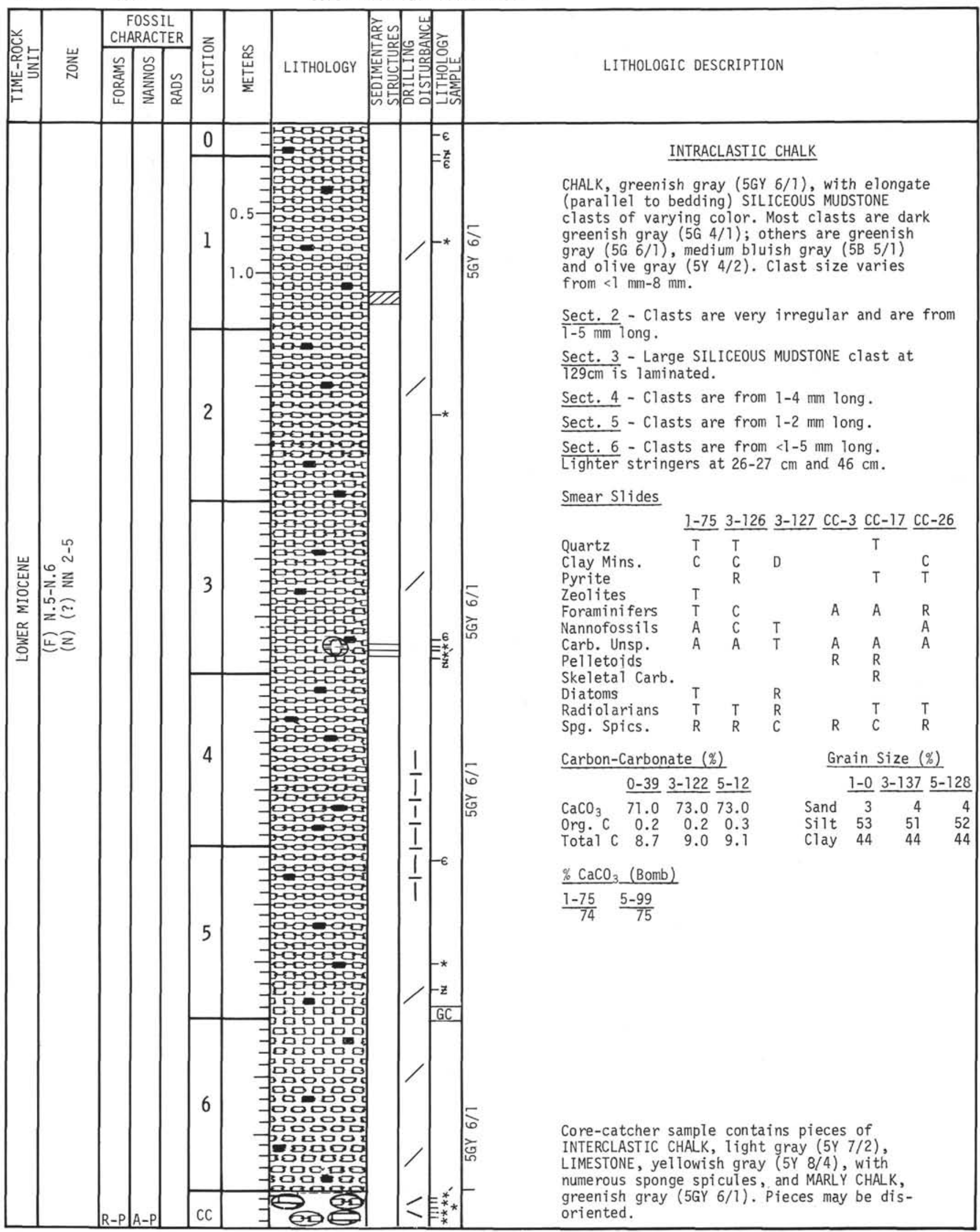


DENSITY $(\mathrm{gm} / \mathrm{cc})$

SONIC VELOCITY $(\mathrm{km} / \mathrm{sec})$

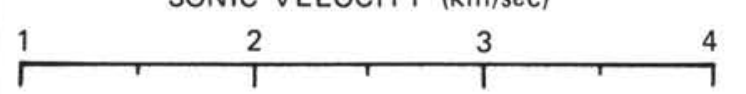

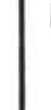
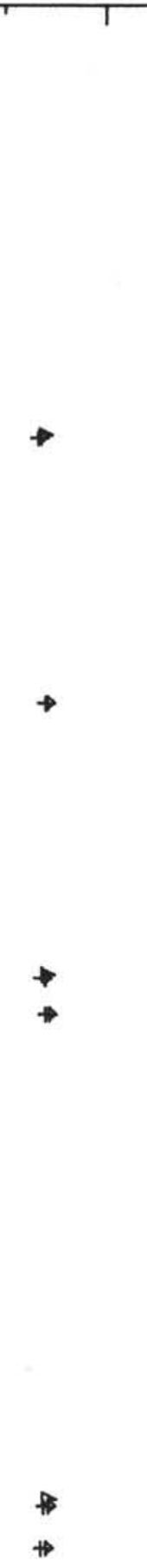

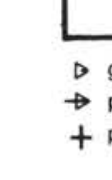

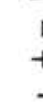




\begin{tabular}{|c|c|c|c|c|c|c|c|c|c|}
\hline \multirow{2}{*}{ 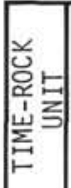 } & \multirow[b]{2}{*}{ 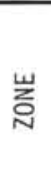 } & \multicolumn{3}{|c|}{$\begin{array}{c}\text { FOSSIL } \\
\text { CHARACTER }\end{array}$} & \multirow{2}{*}{ 总 } & \multirow[b]{2}{*}{ 岂 } & \multirow[b]{2}{*}{ LITHOLOGY } & \multirow{2}{*}{ 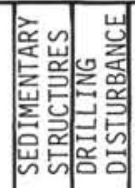 } & \multirow[b]{2}{*}{ LITHOLOGIC DESCRIPTION } \\
\hline & & 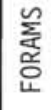 & 竞 & ईू & & & & & \\
\hline \multirow{4}{*}{ 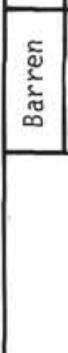 } & & - & - & - & & & \multirow{4}{*}{\multicolumn{2}{|c|}{ 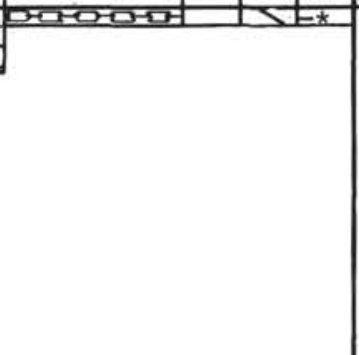 }} & \multirow{2}{*}{$\begin{array}{l}\text { CHALK } \\
\text { Entire recovery consists of a } 10 \mathrm{cc} \text { core- } \\
\text { catcher sample of greenish gray }(5 \mathrm{GY} 6 / 1) \text {, } \\
\text { homogeneous CHALK. }\end{array}$} \\
\hline & & & & & $C C$ & & & & \\
\hline & & & & & & & & & Smear slide \\
\hline & & & & & & & & & $\begin{array}{ll}\text { Clay } & \text { C } \\
\text { Nannofossils } & \text { A } \\
\text { Carb. Unsp. } & \text { A } \\
\text { Diatoms } & \text { T } \\
\text { Spg. Spics. } & \text { R }\end{array}$ \\
\hline
\end{tabular}

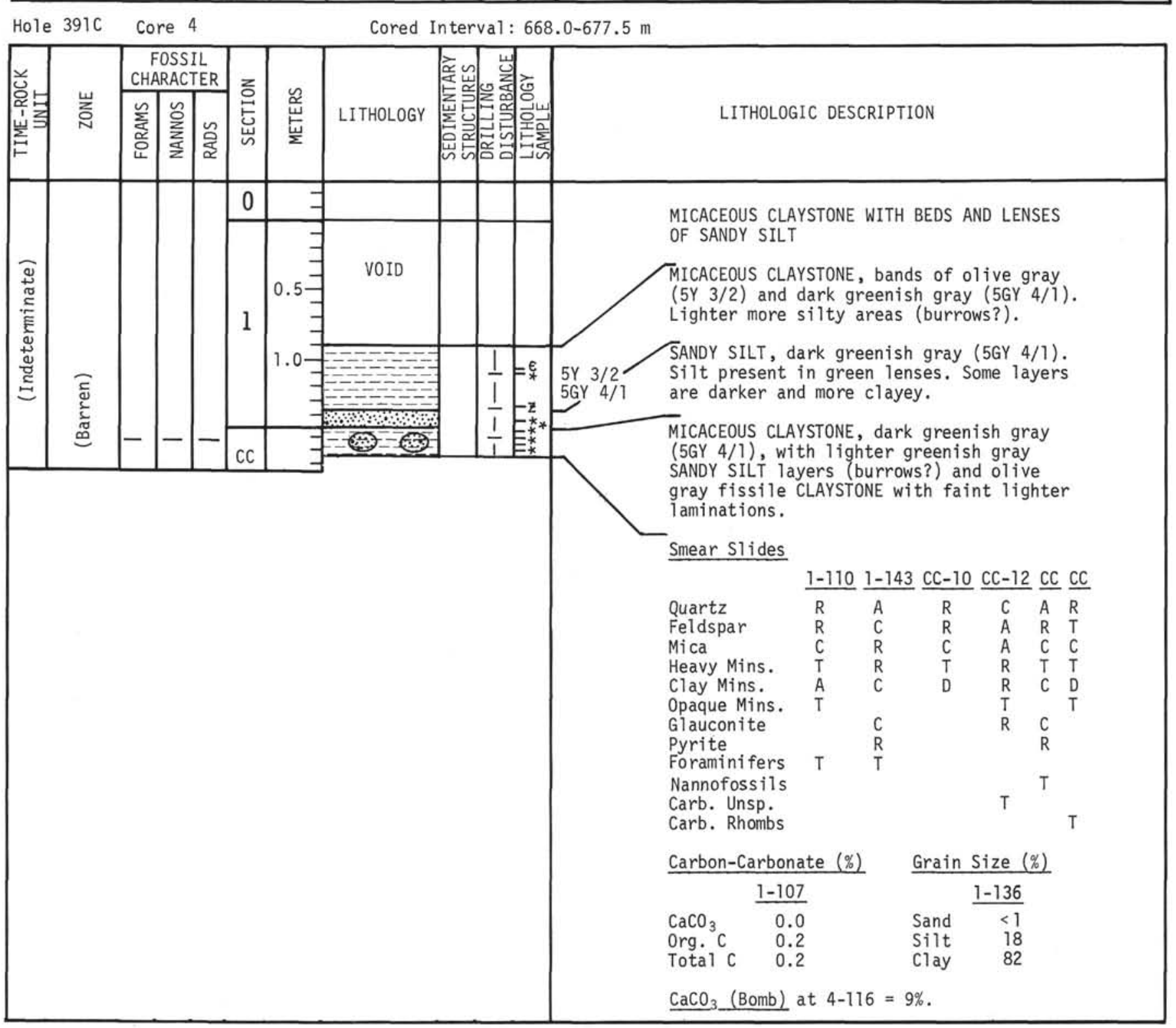




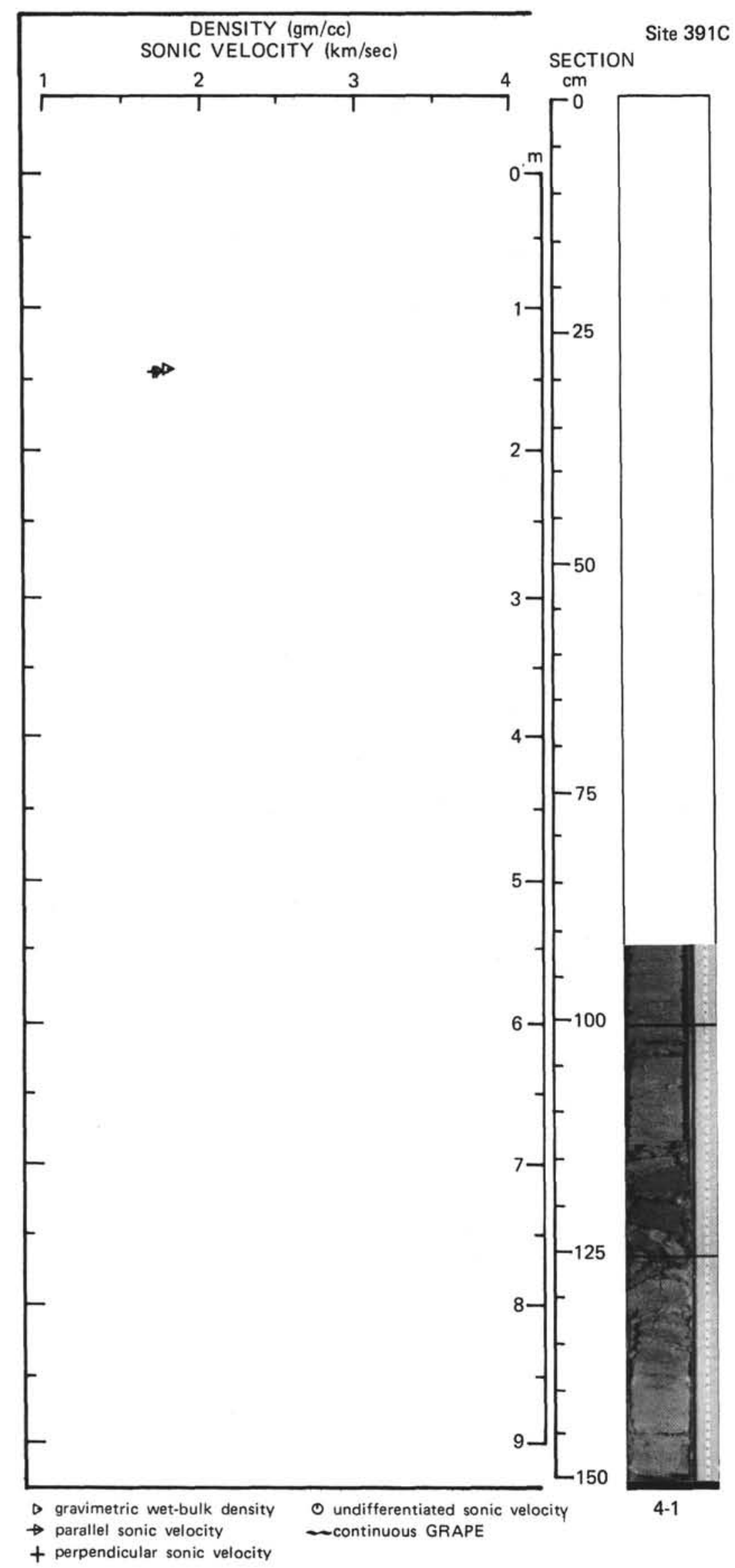


Hole $391 \mathrm{C}$ Core 5

Cored Interval: 677.5-687.5 m

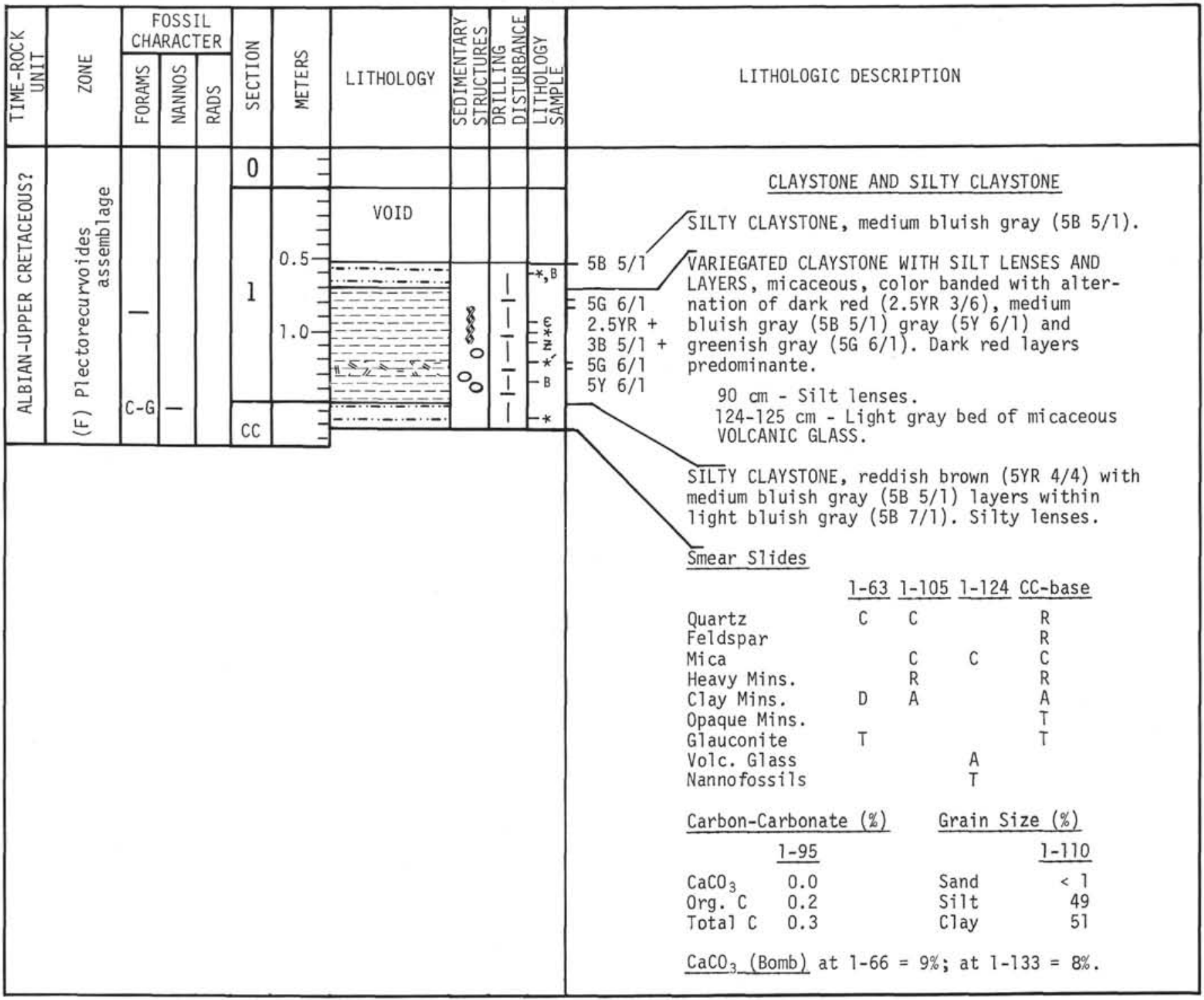




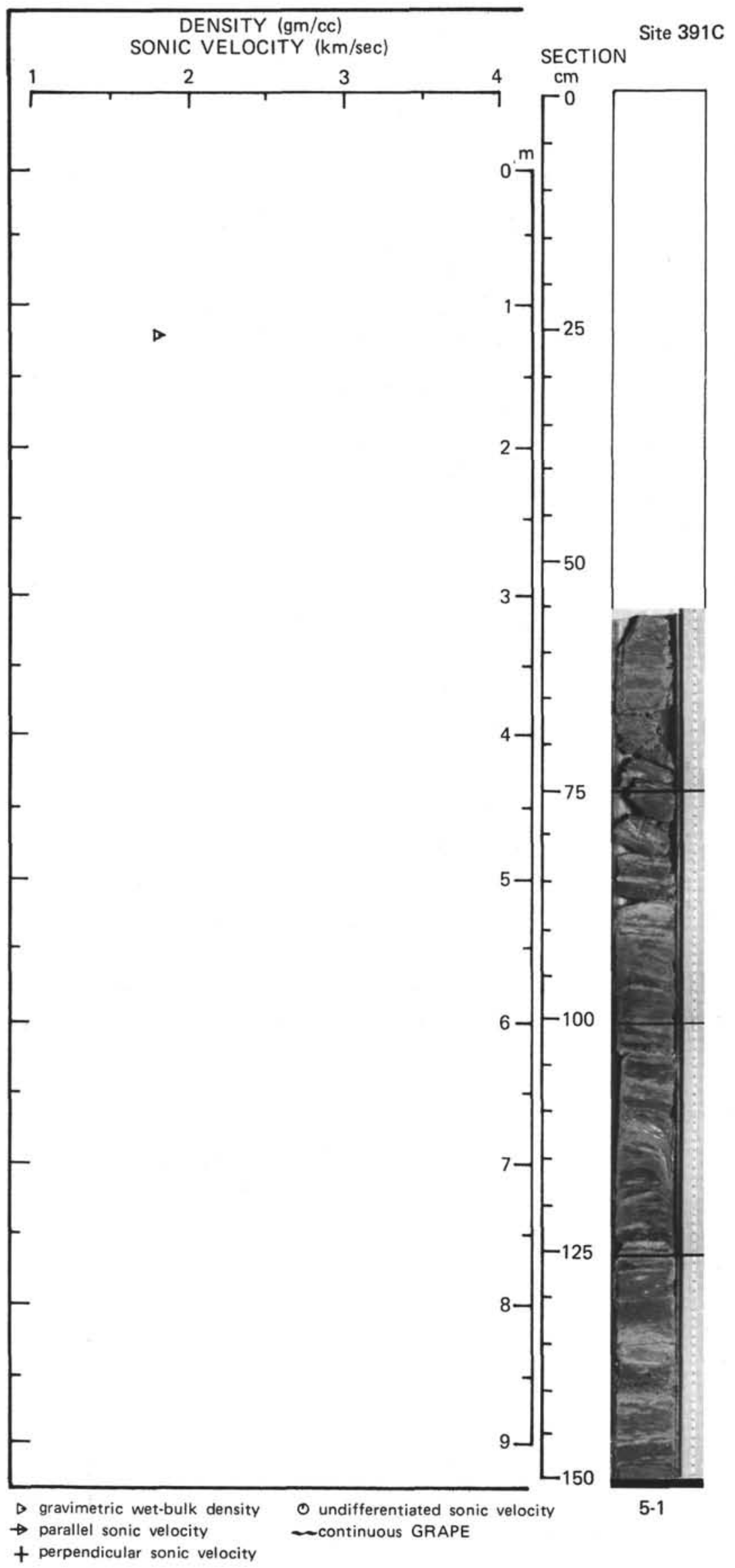


Hole 391C Core 6

Cored Interva1: 687.0-696.5 m

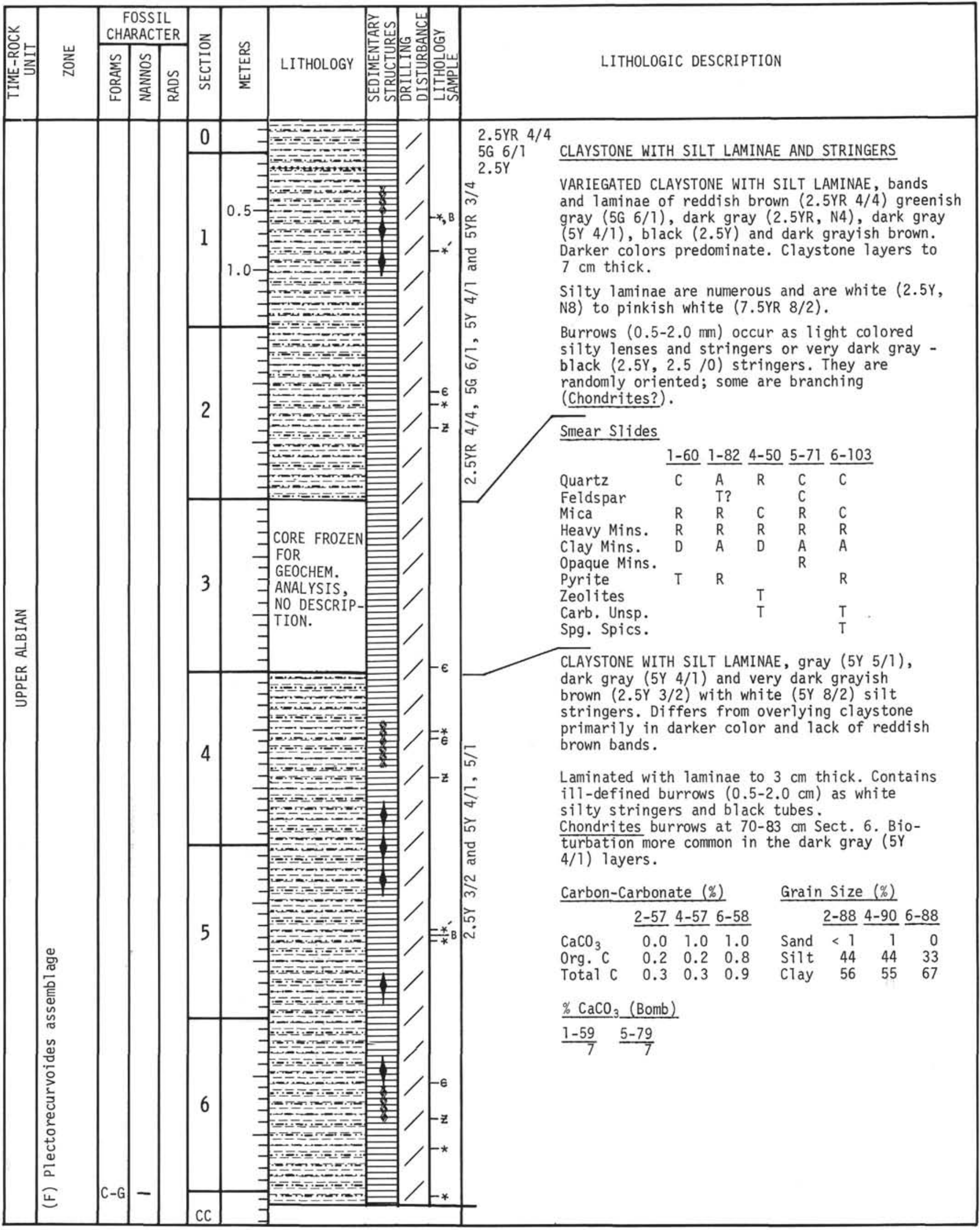




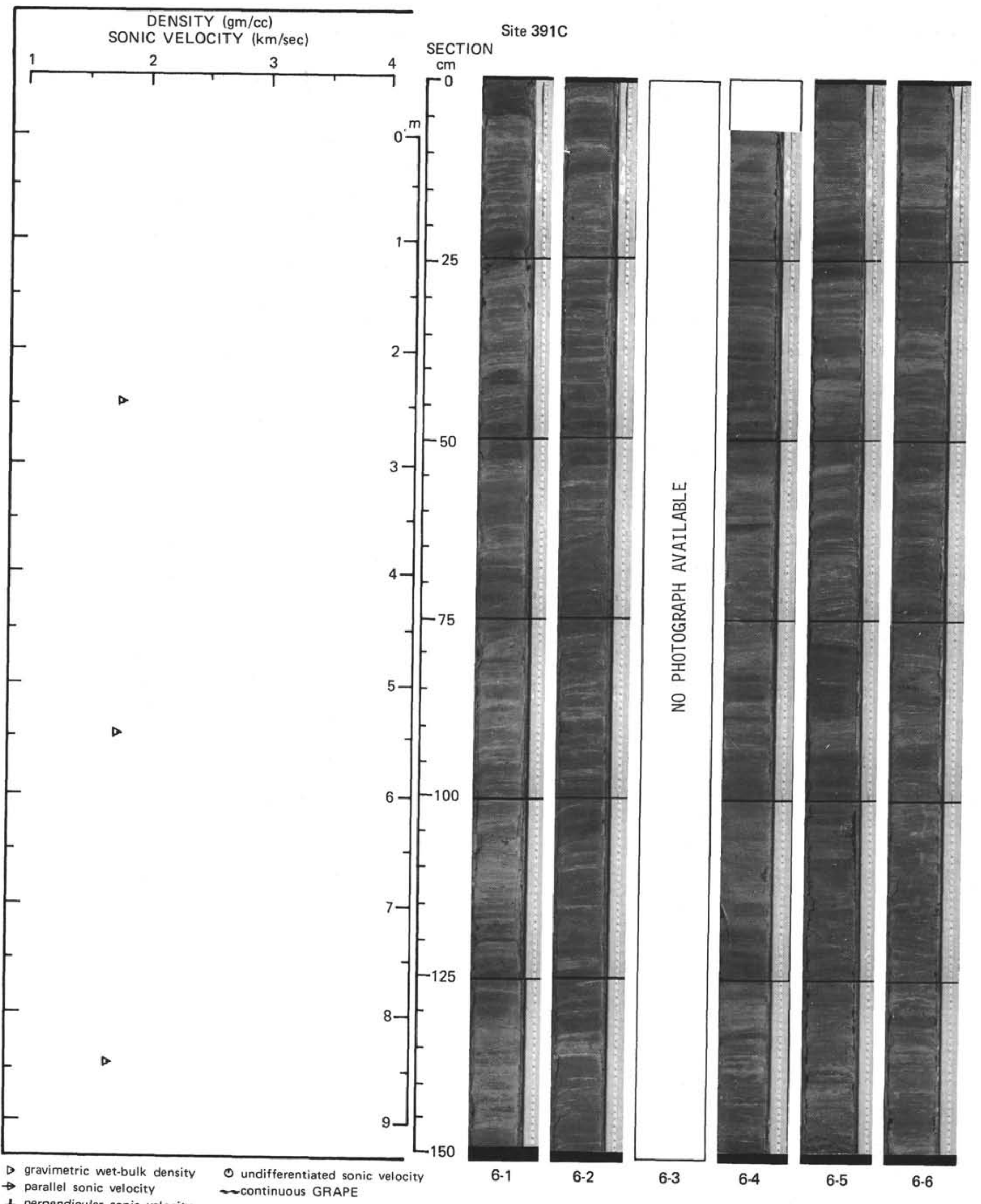


Hole $391 \mathrm{C}$ Core 7

Cored Interval: 725.0-734.5 m

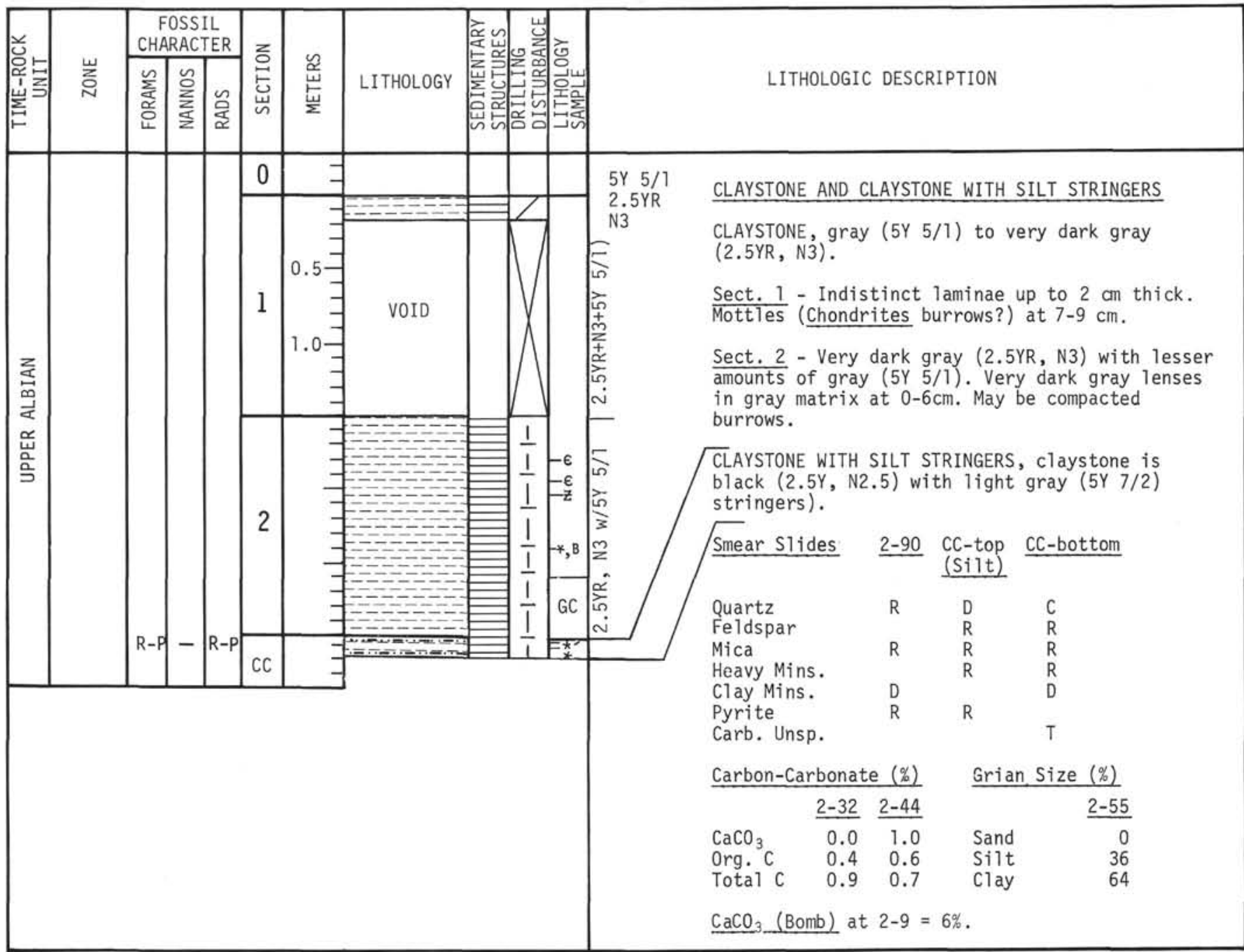




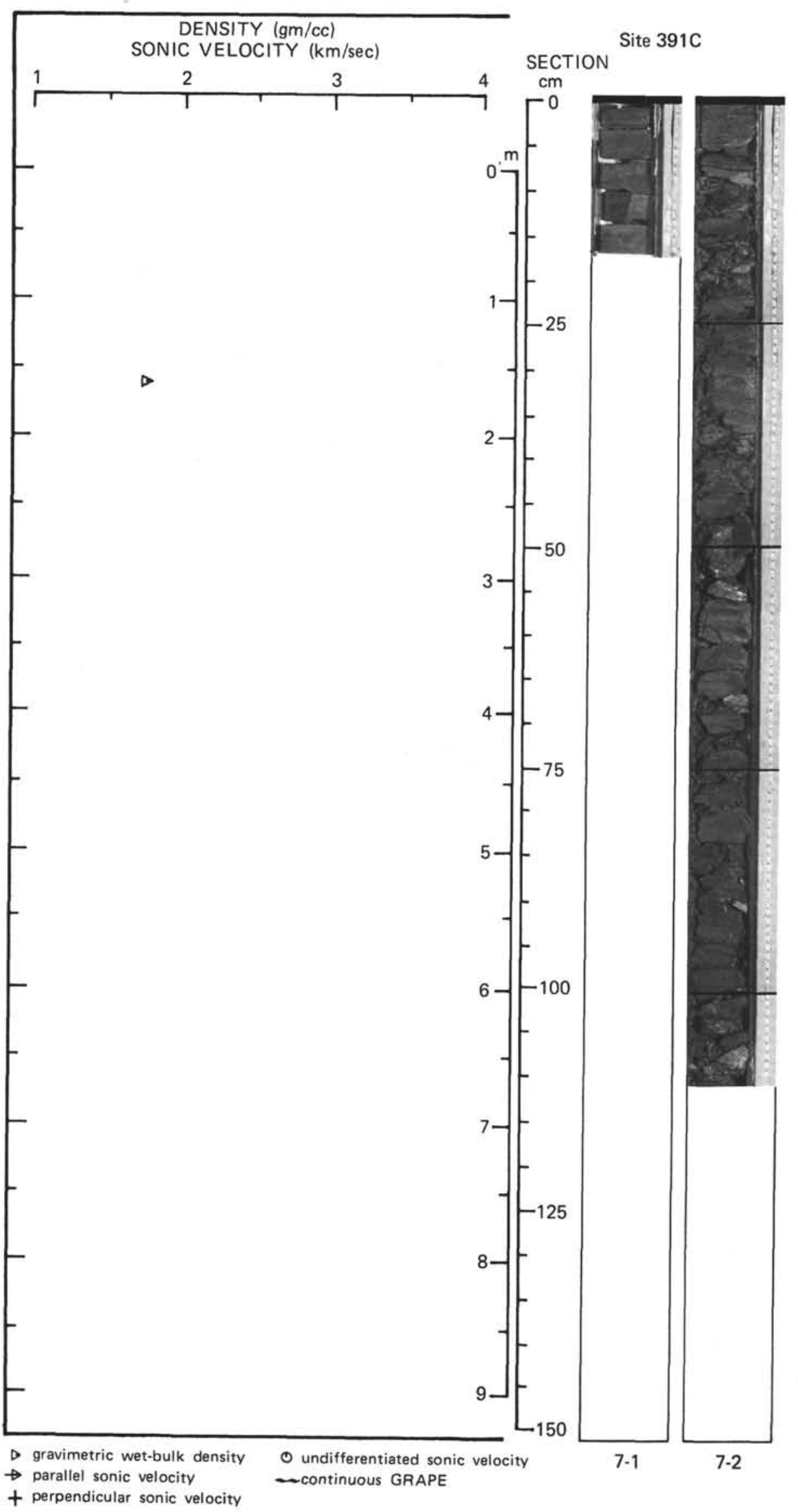




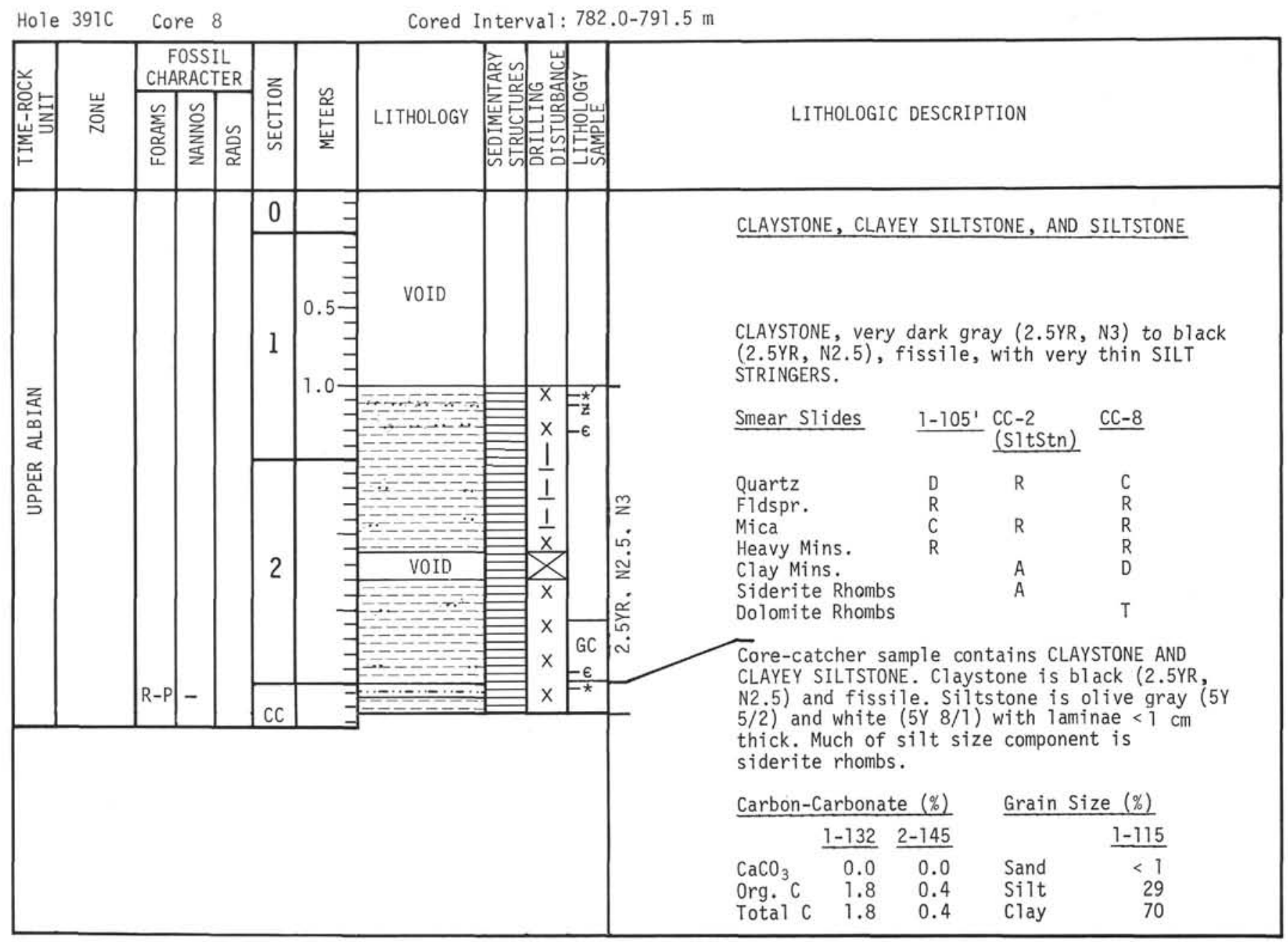




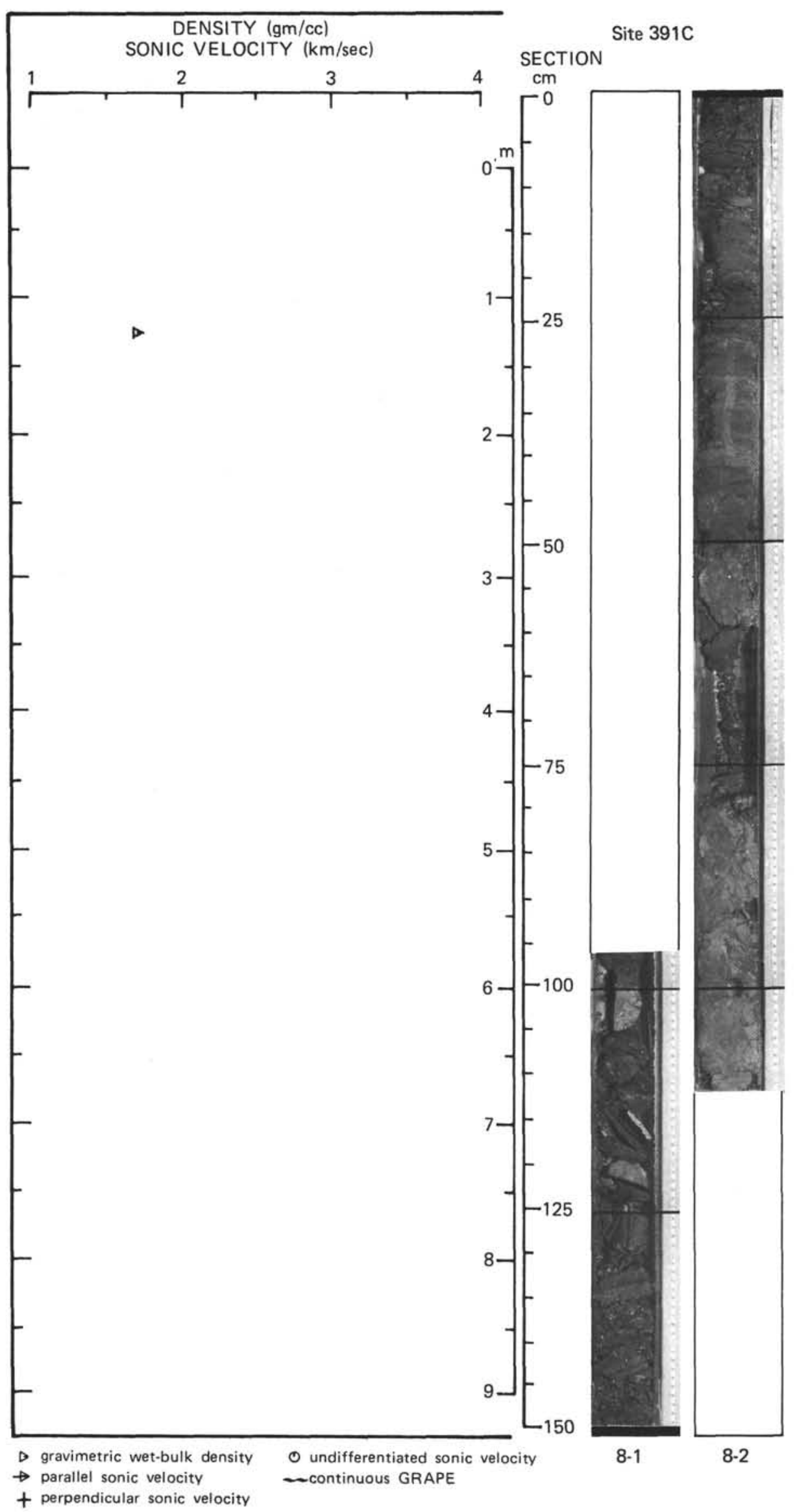




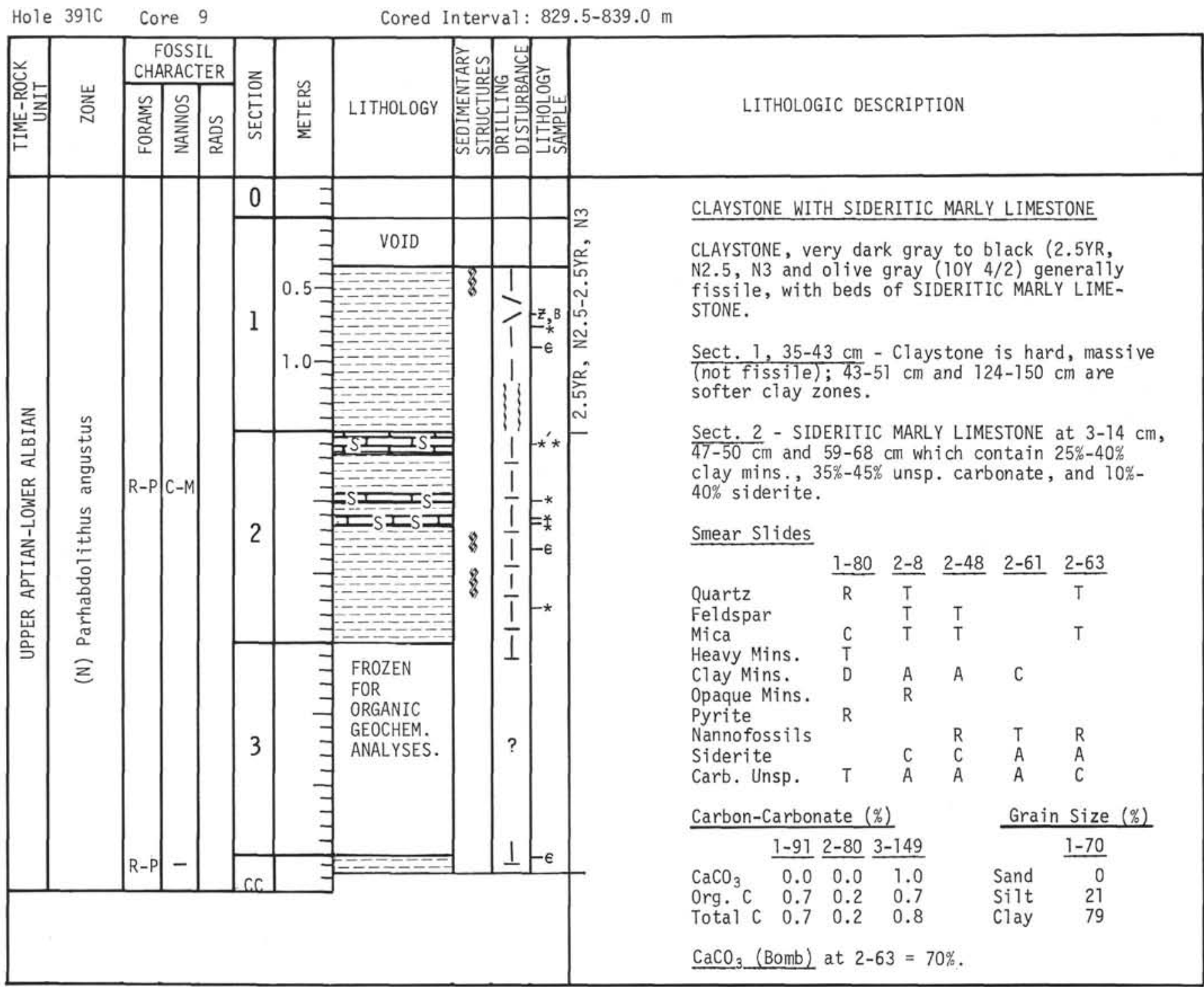




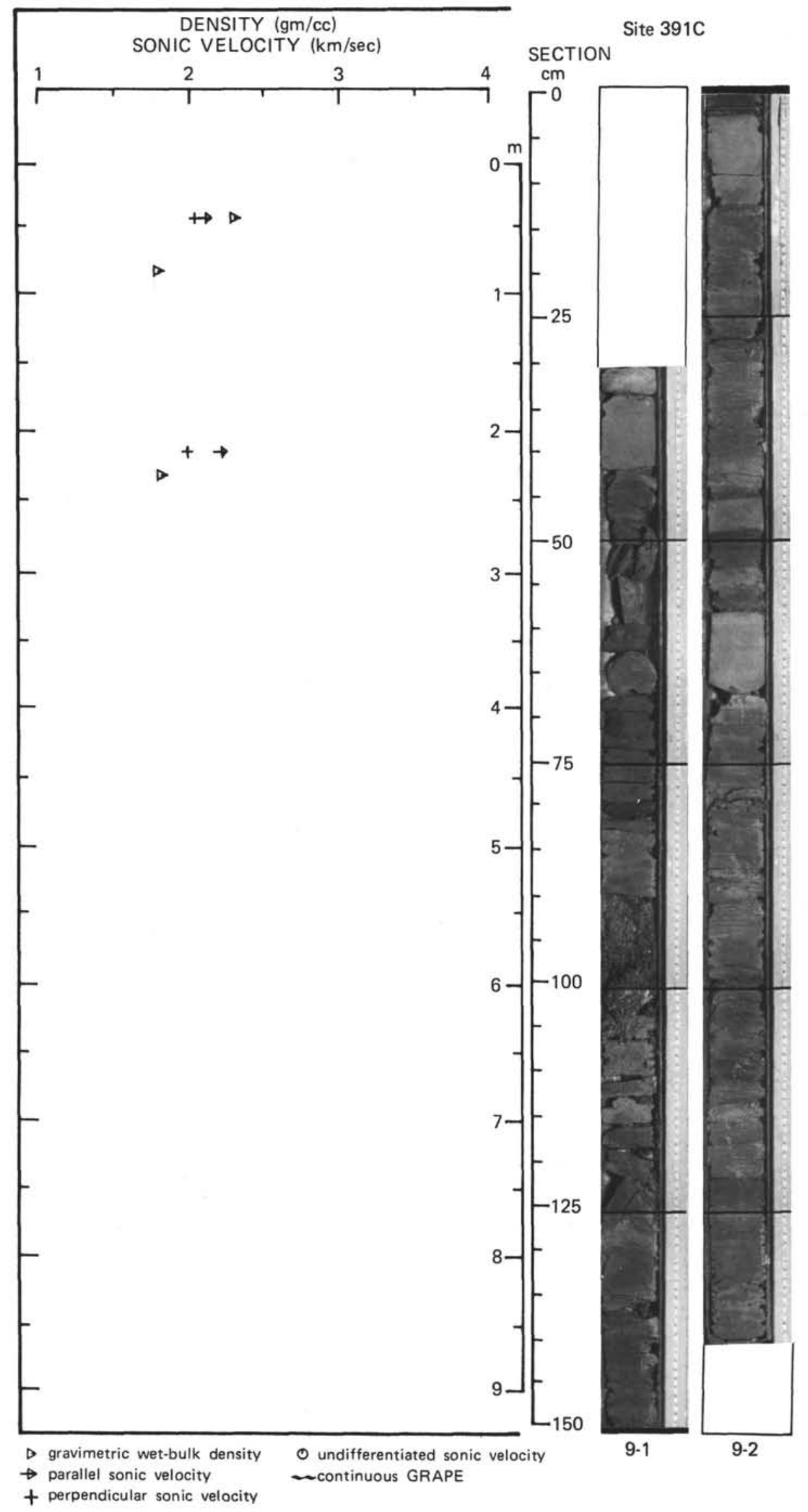




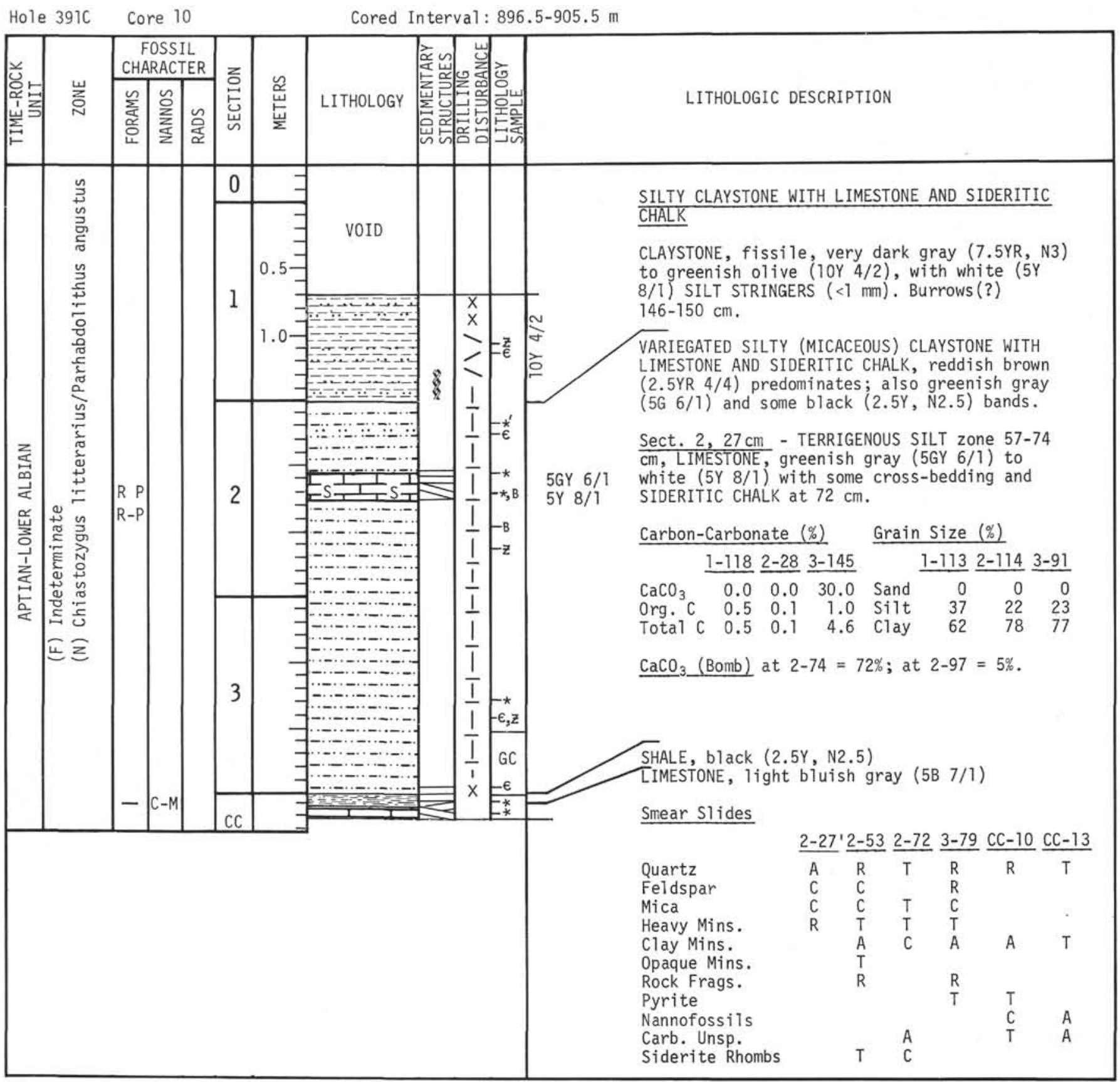


SITE 391

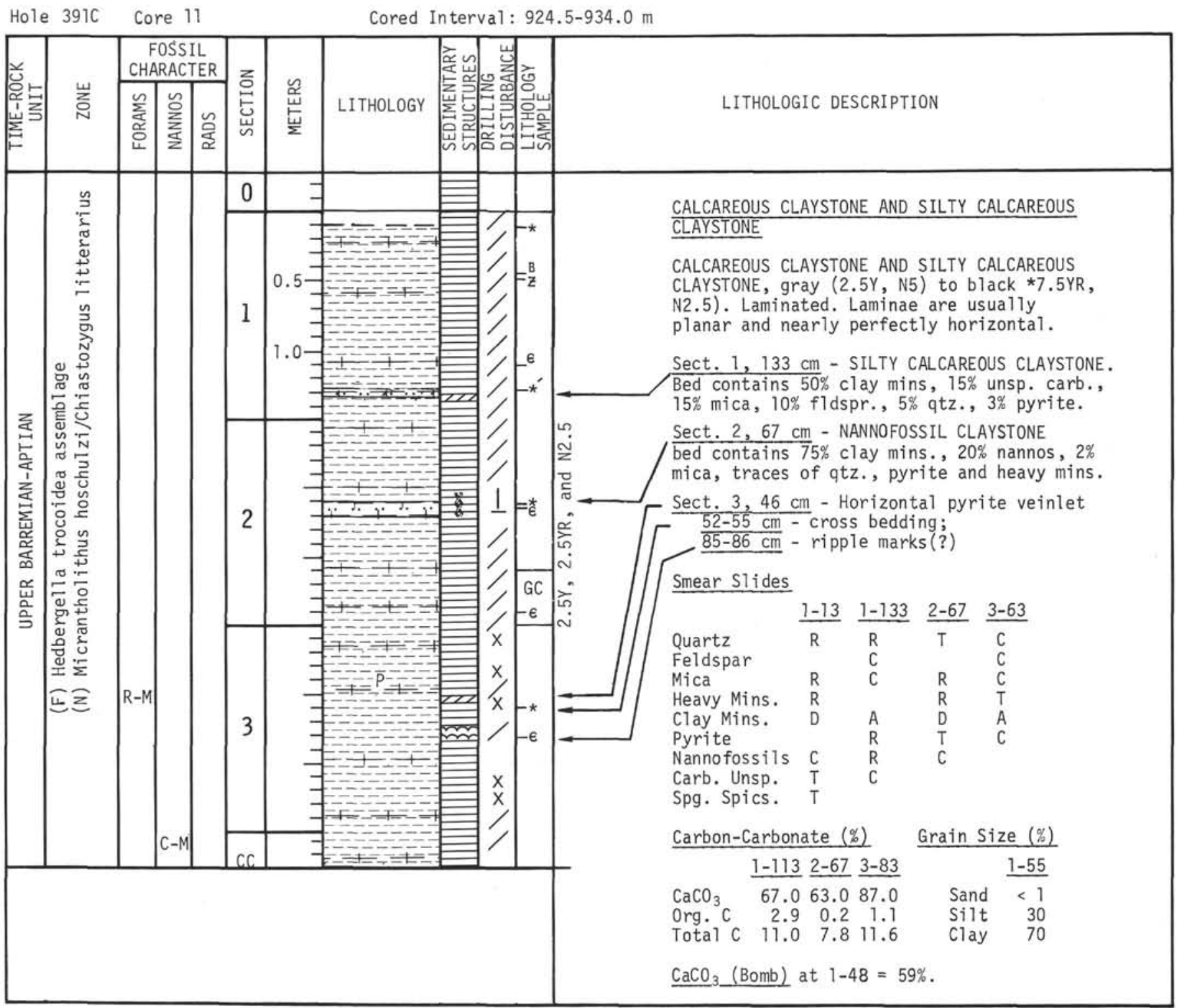




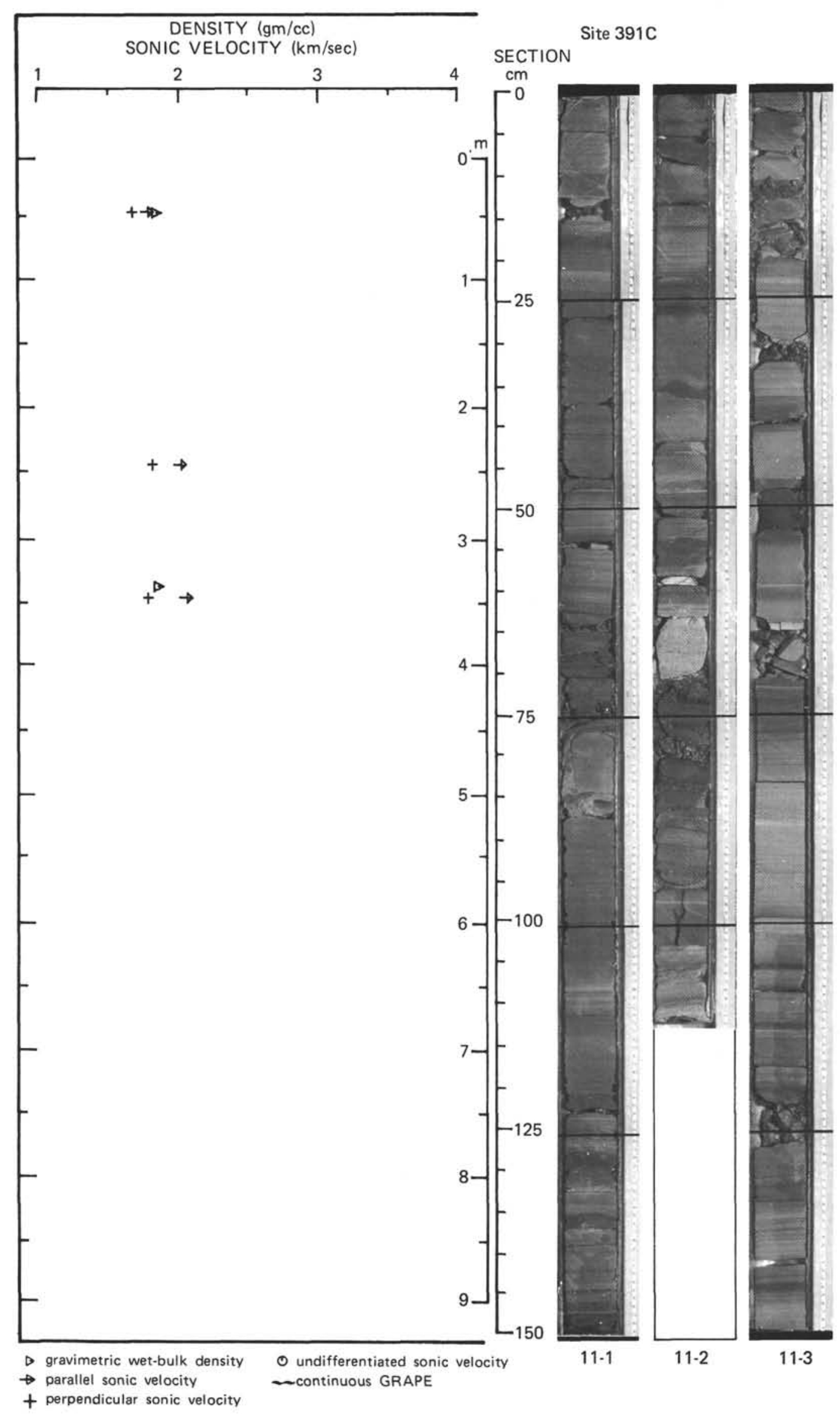




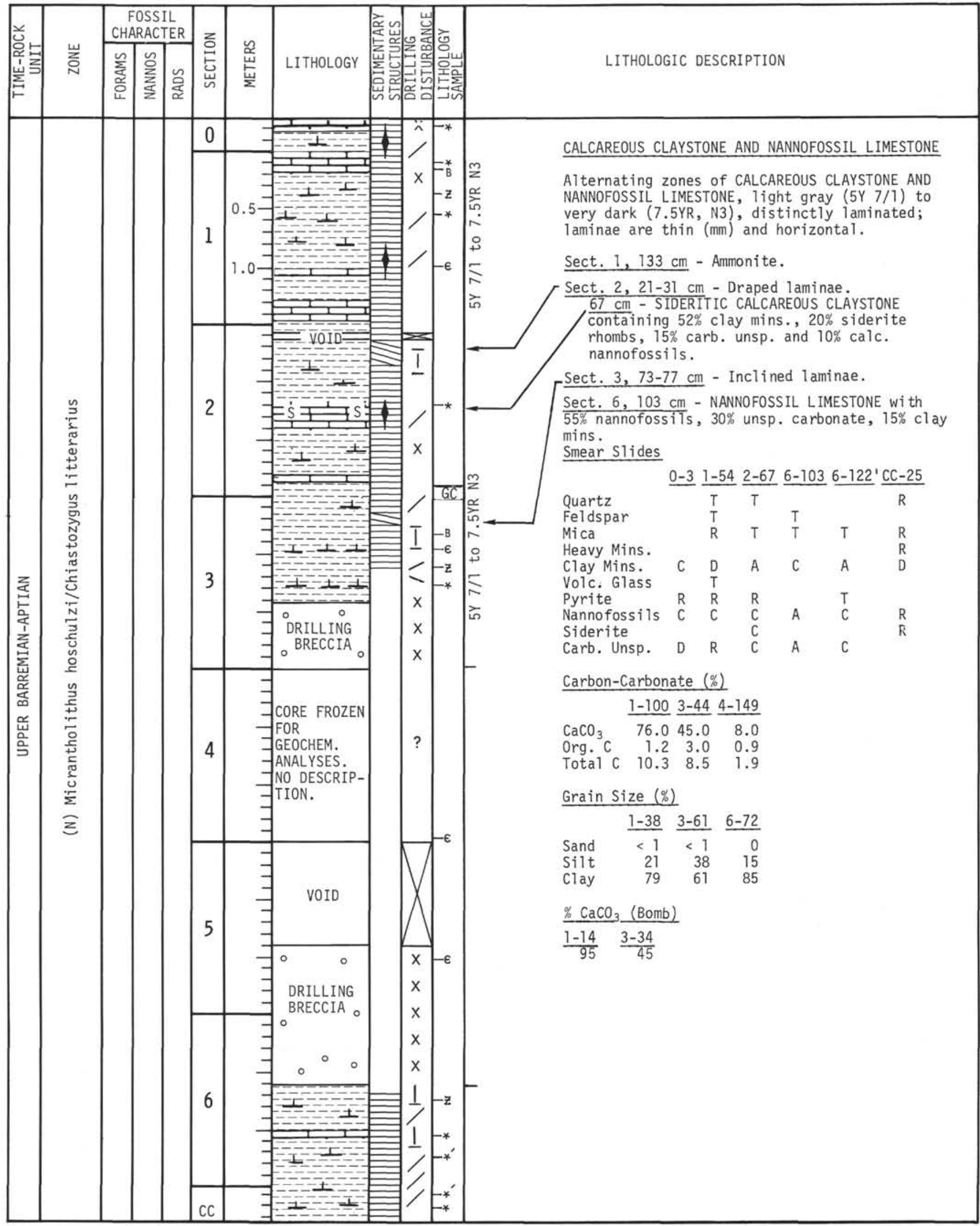




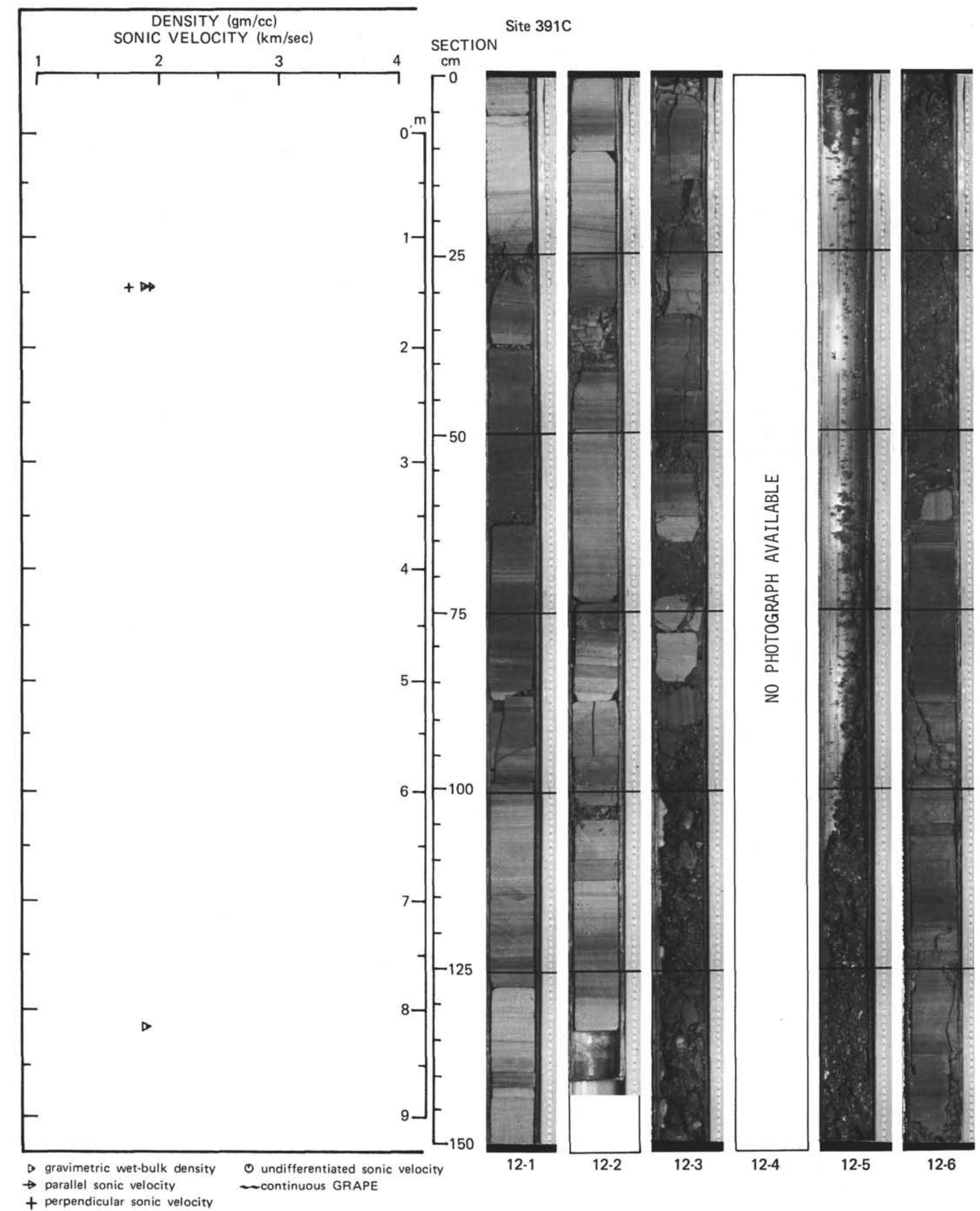




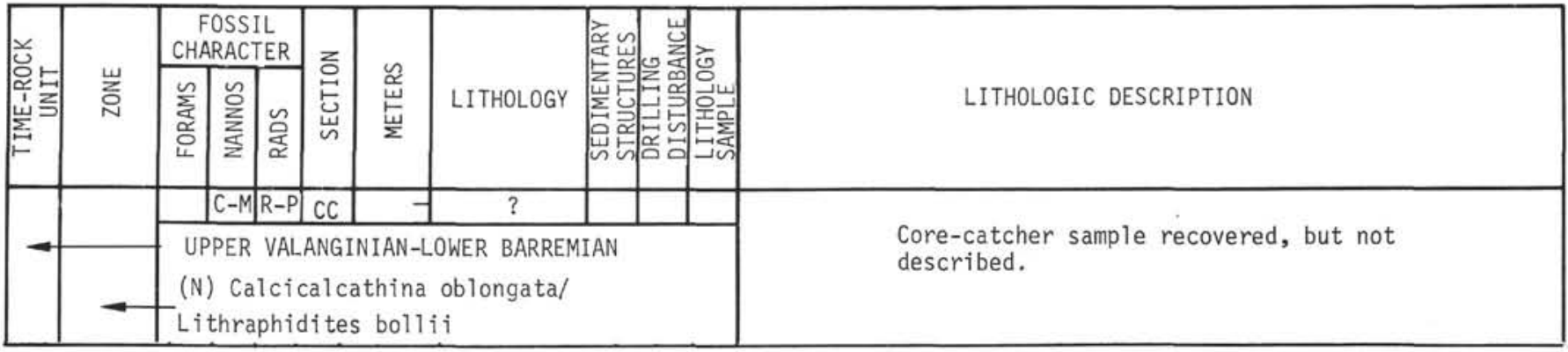

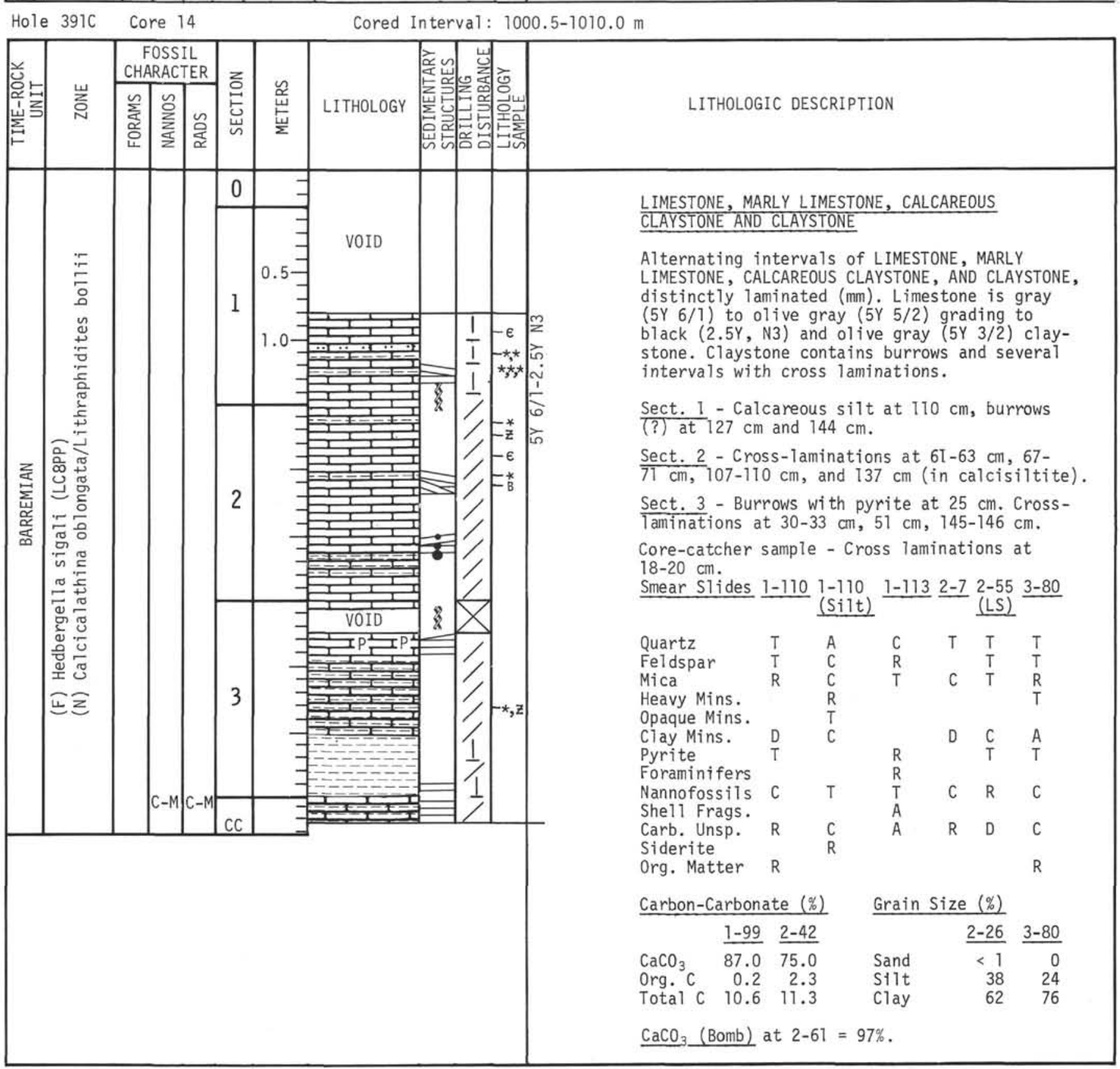




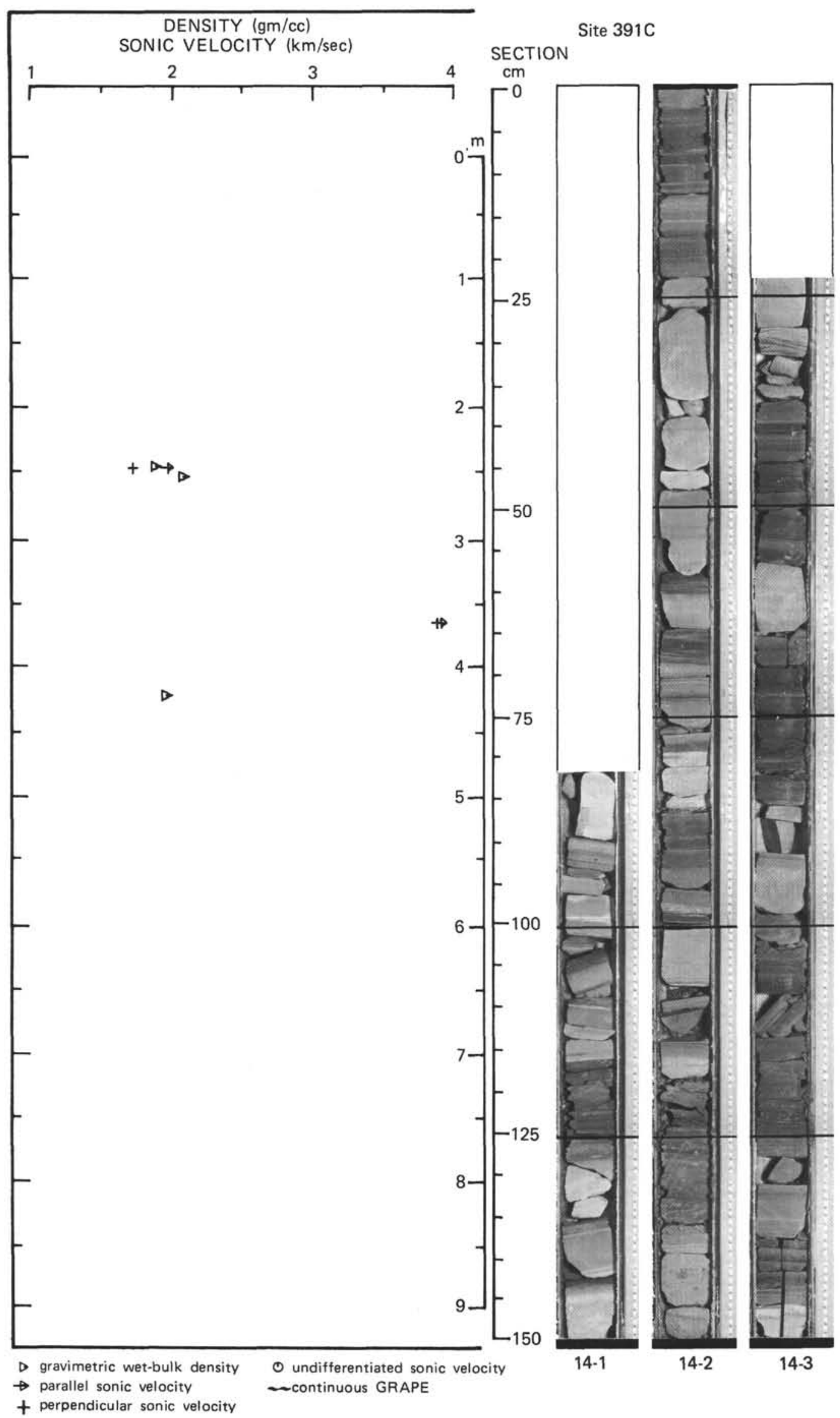




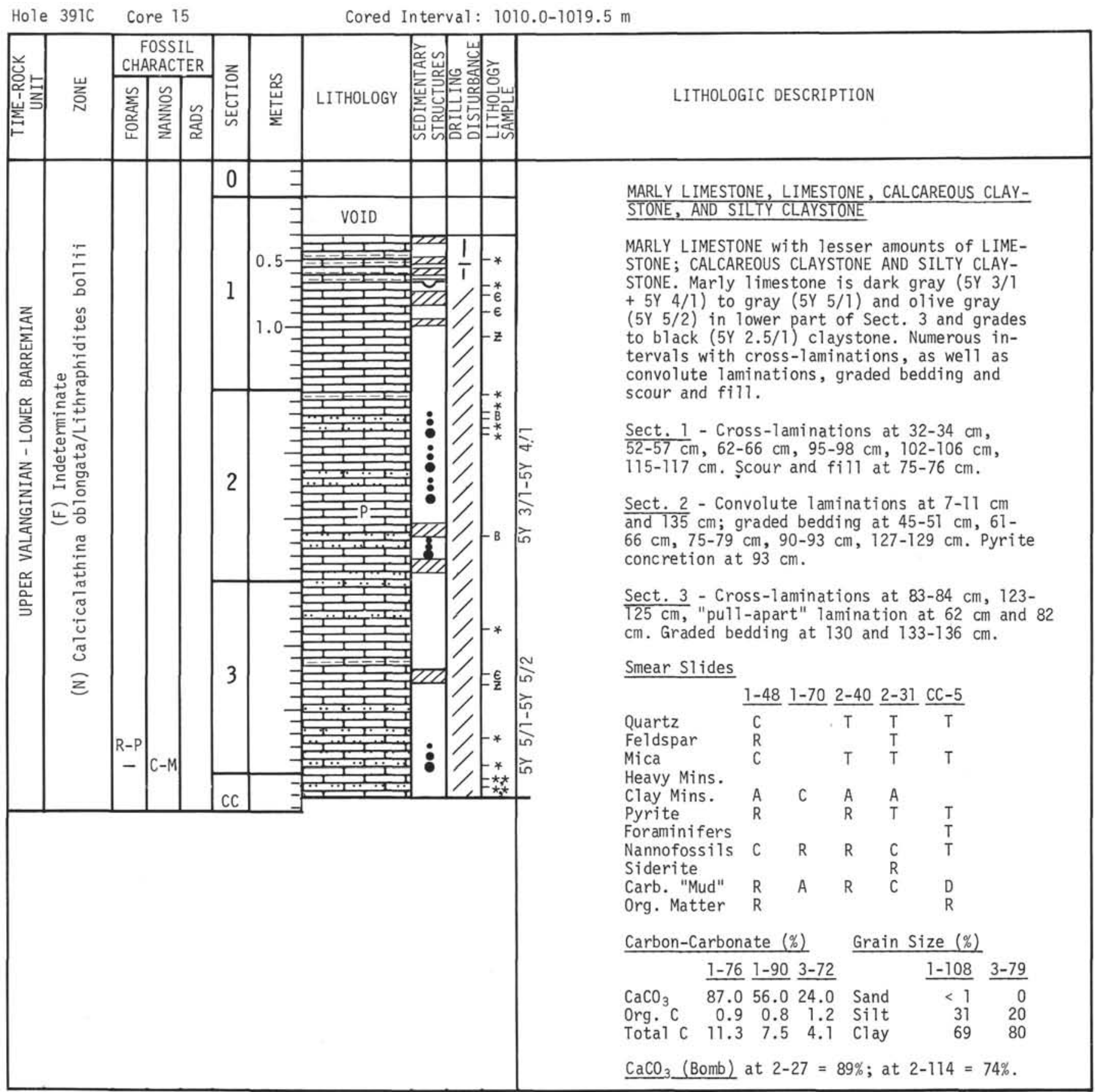




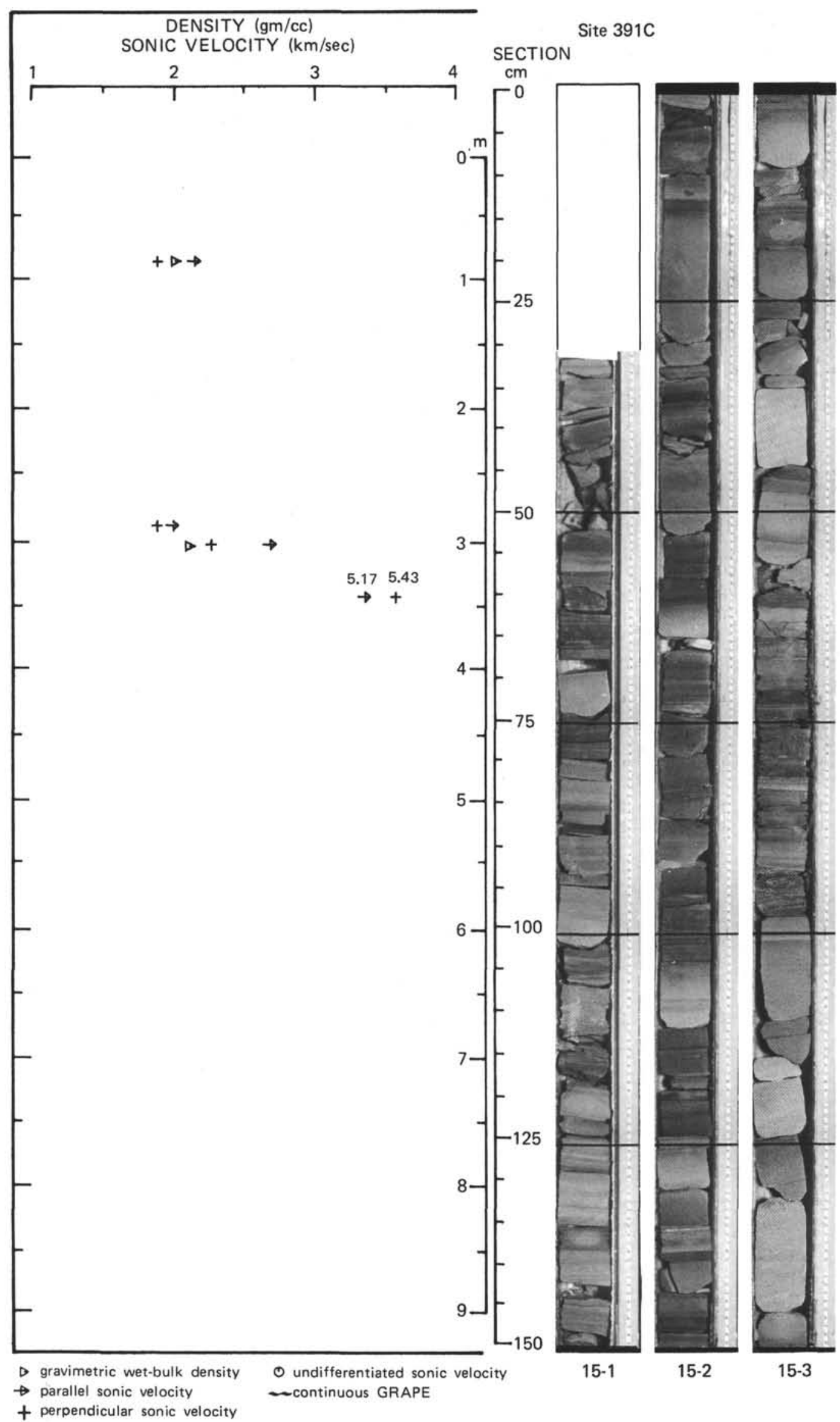




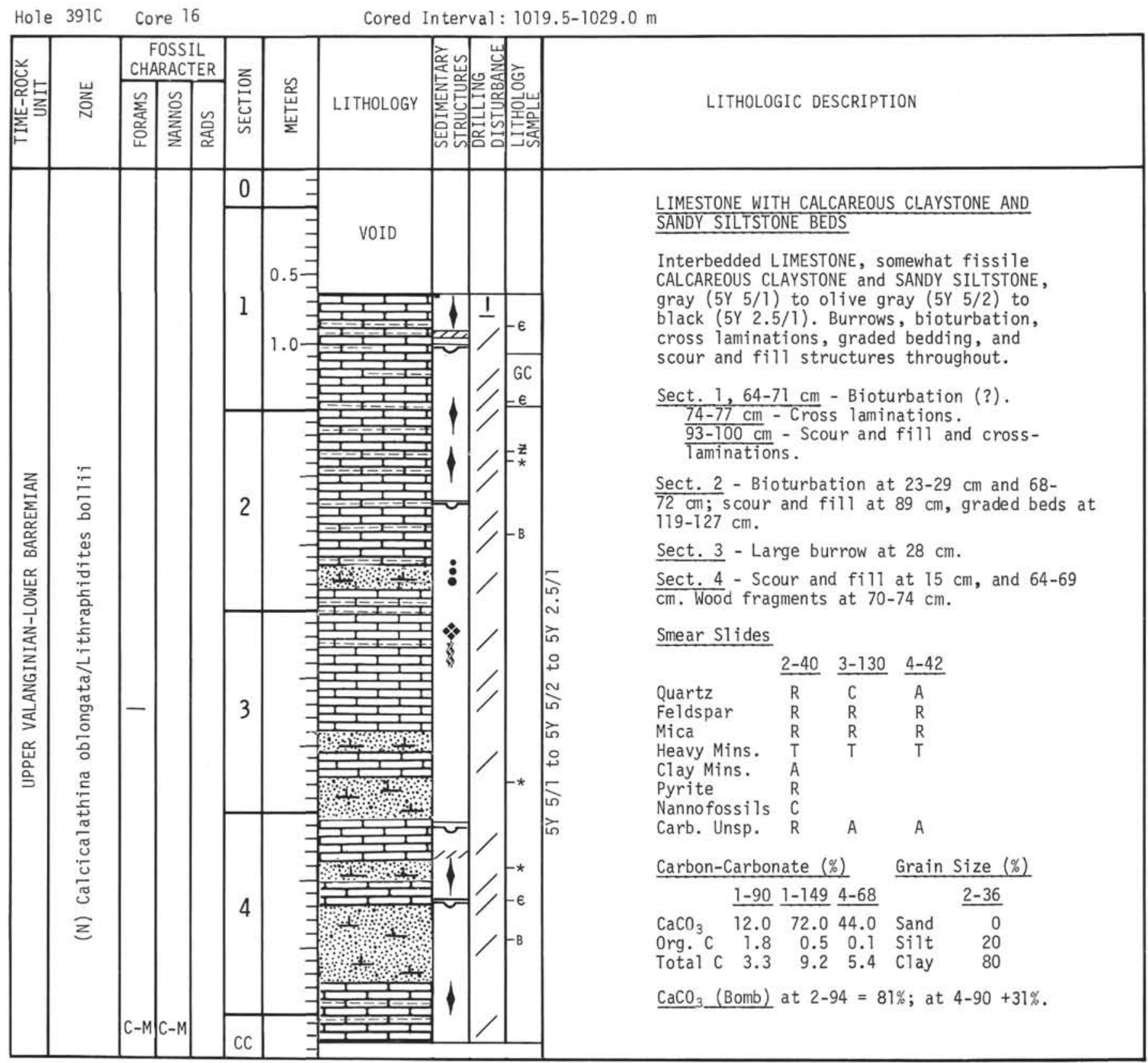




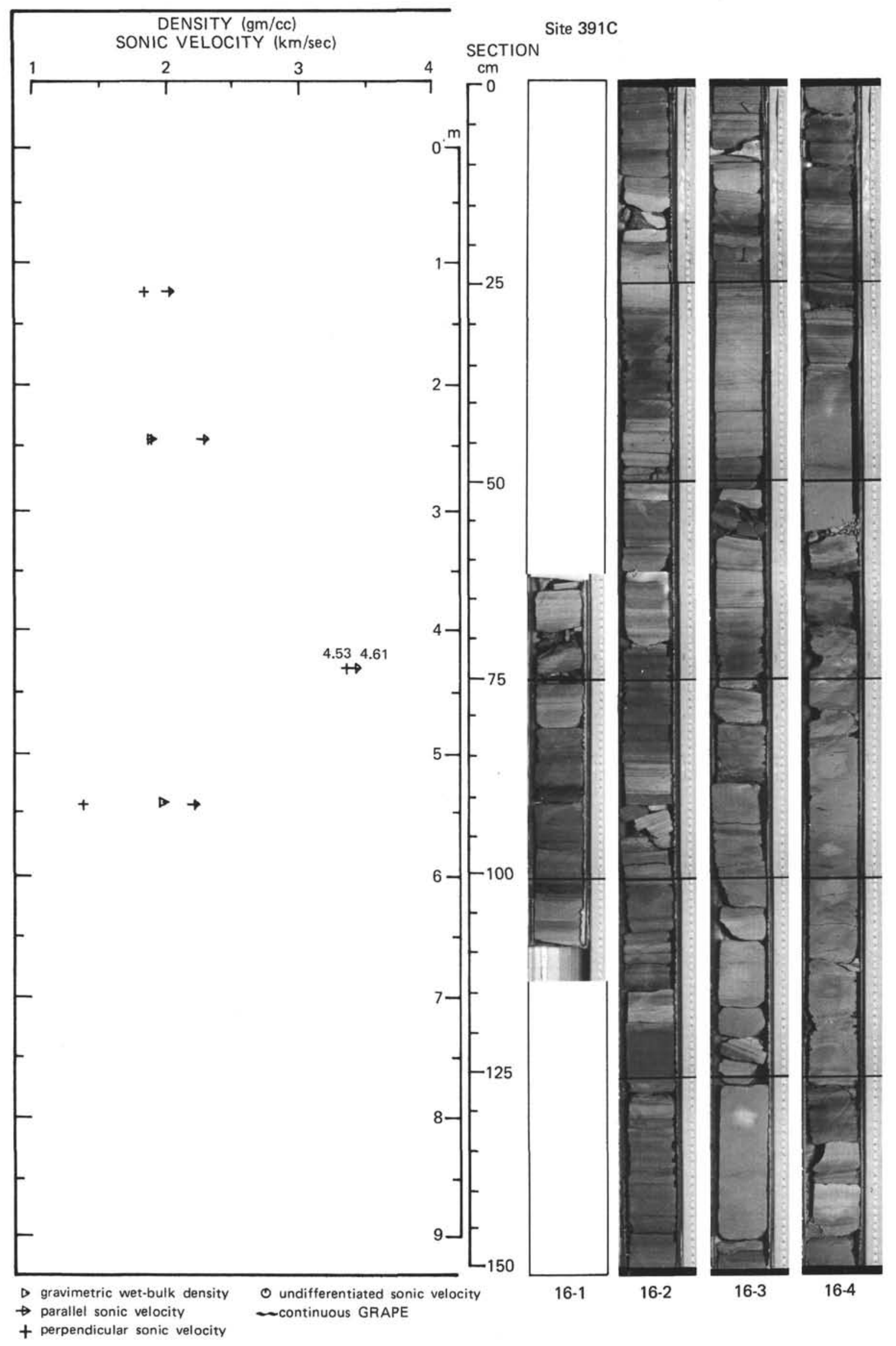




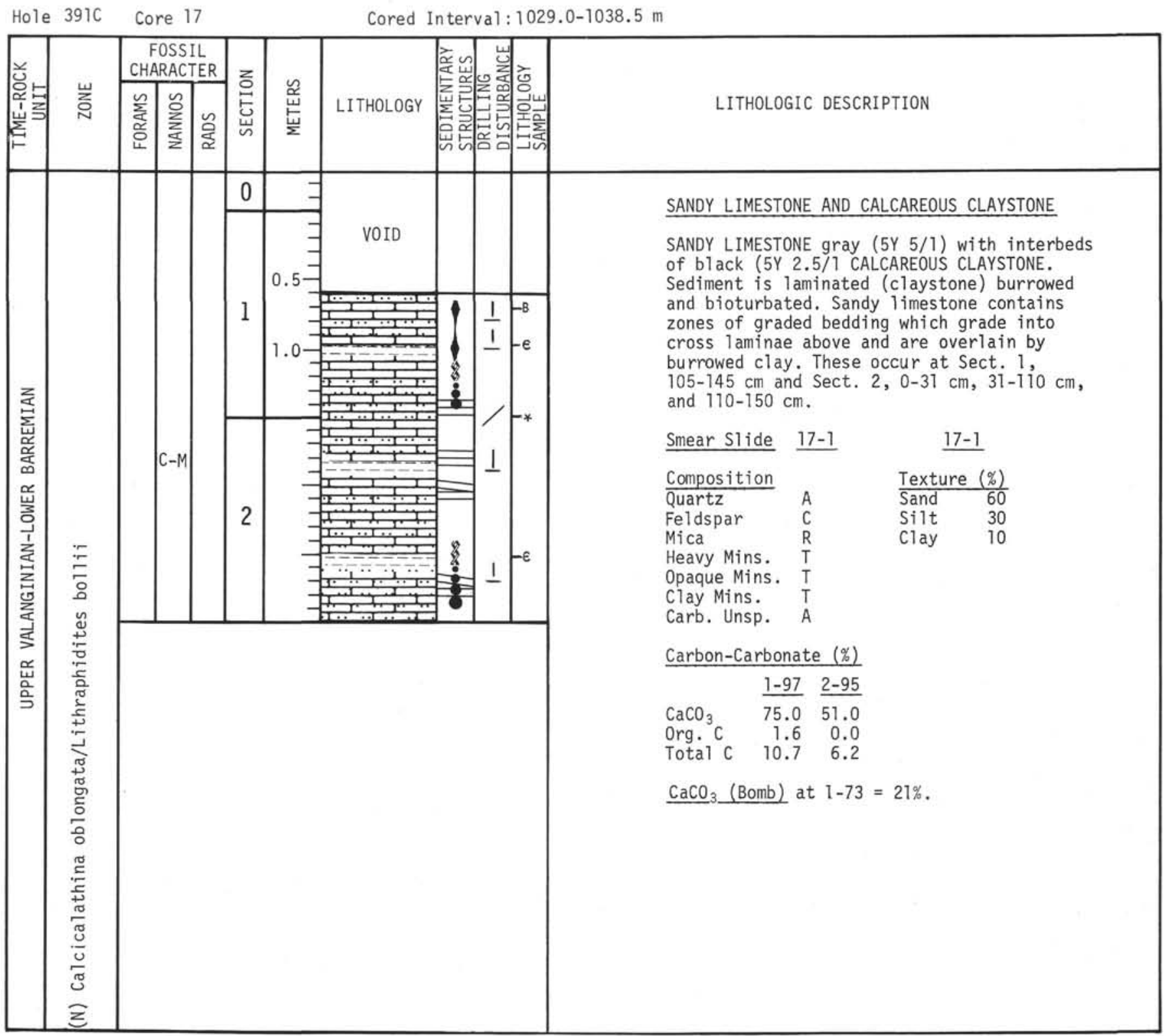




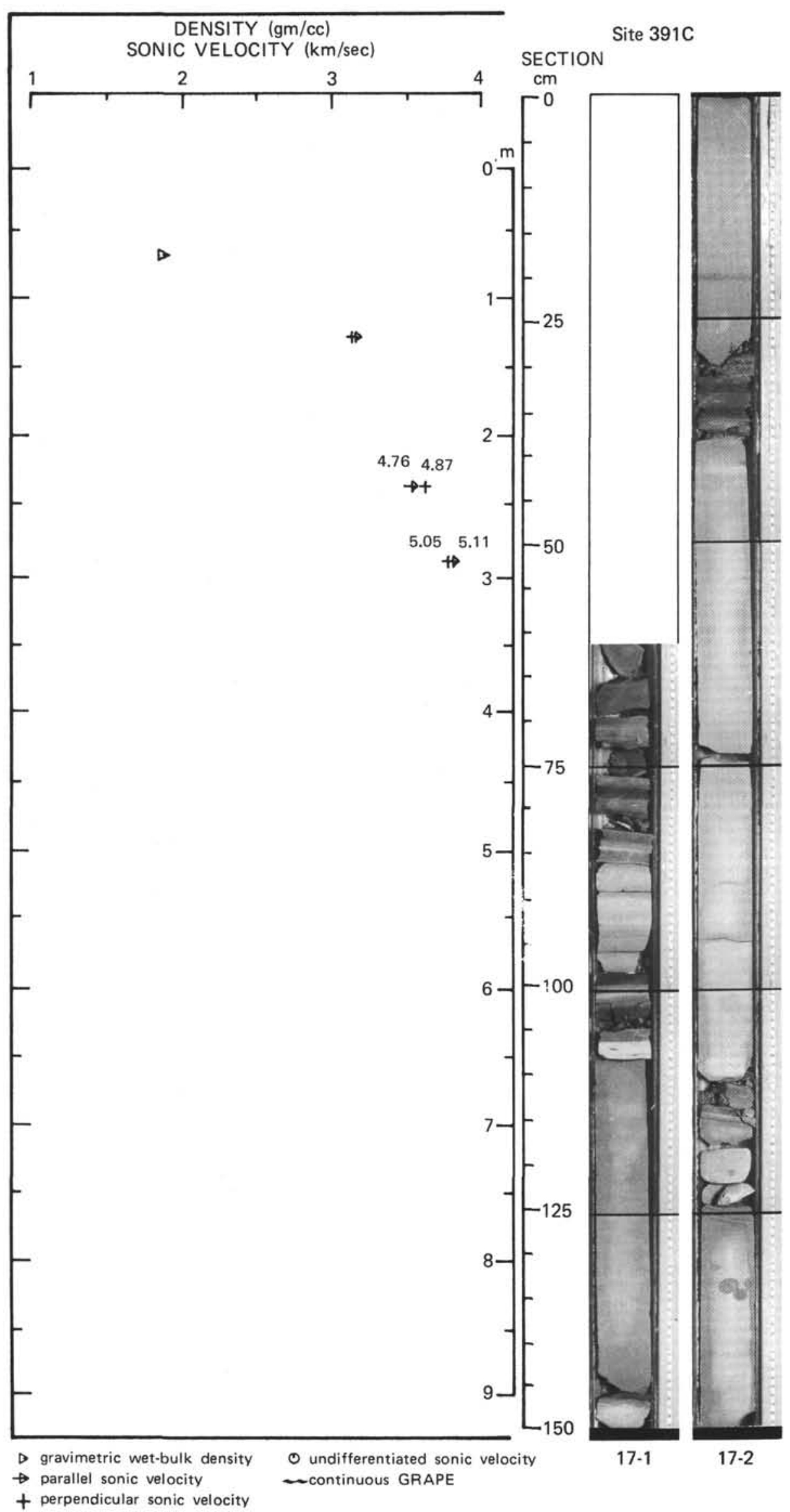




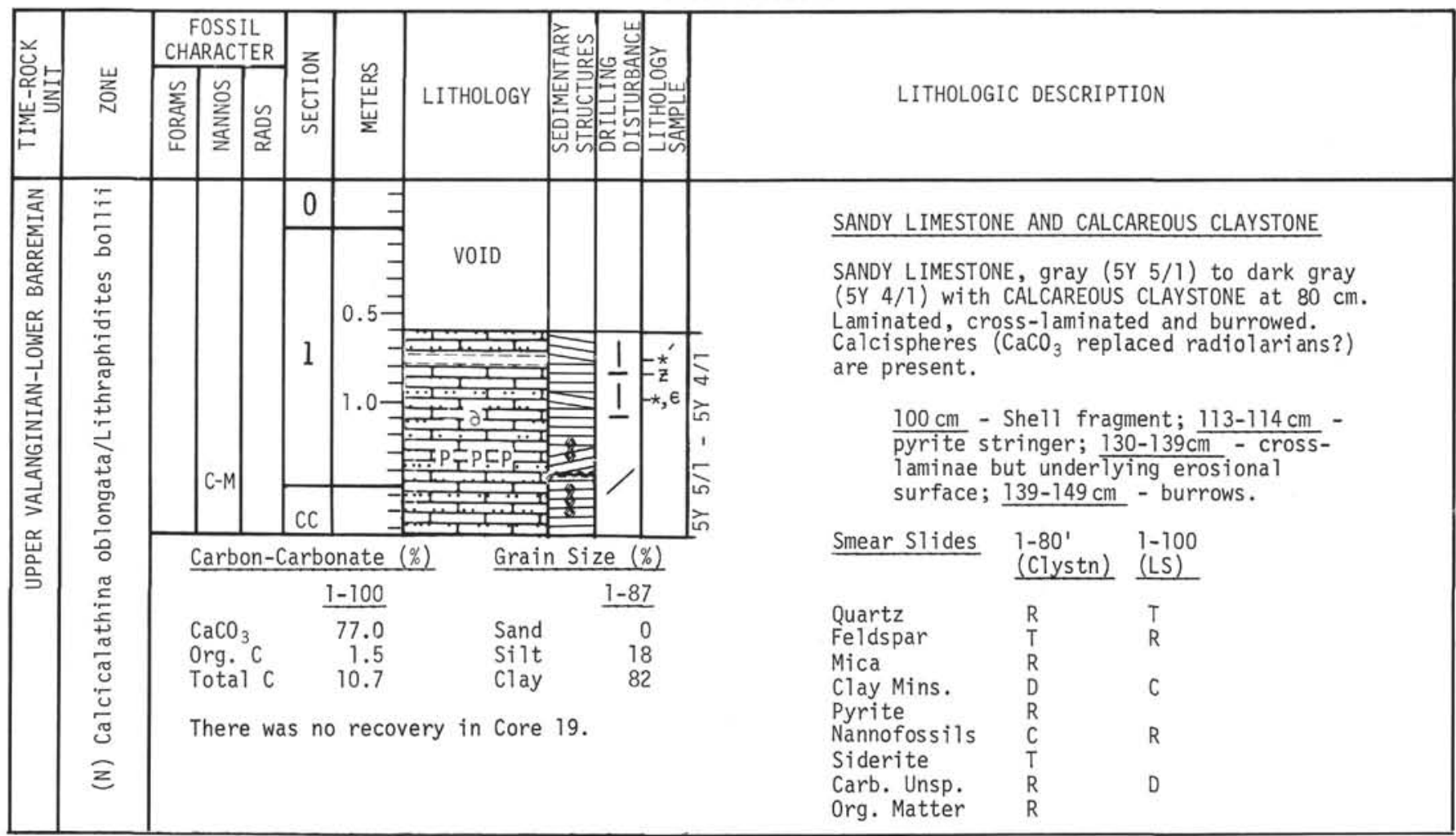

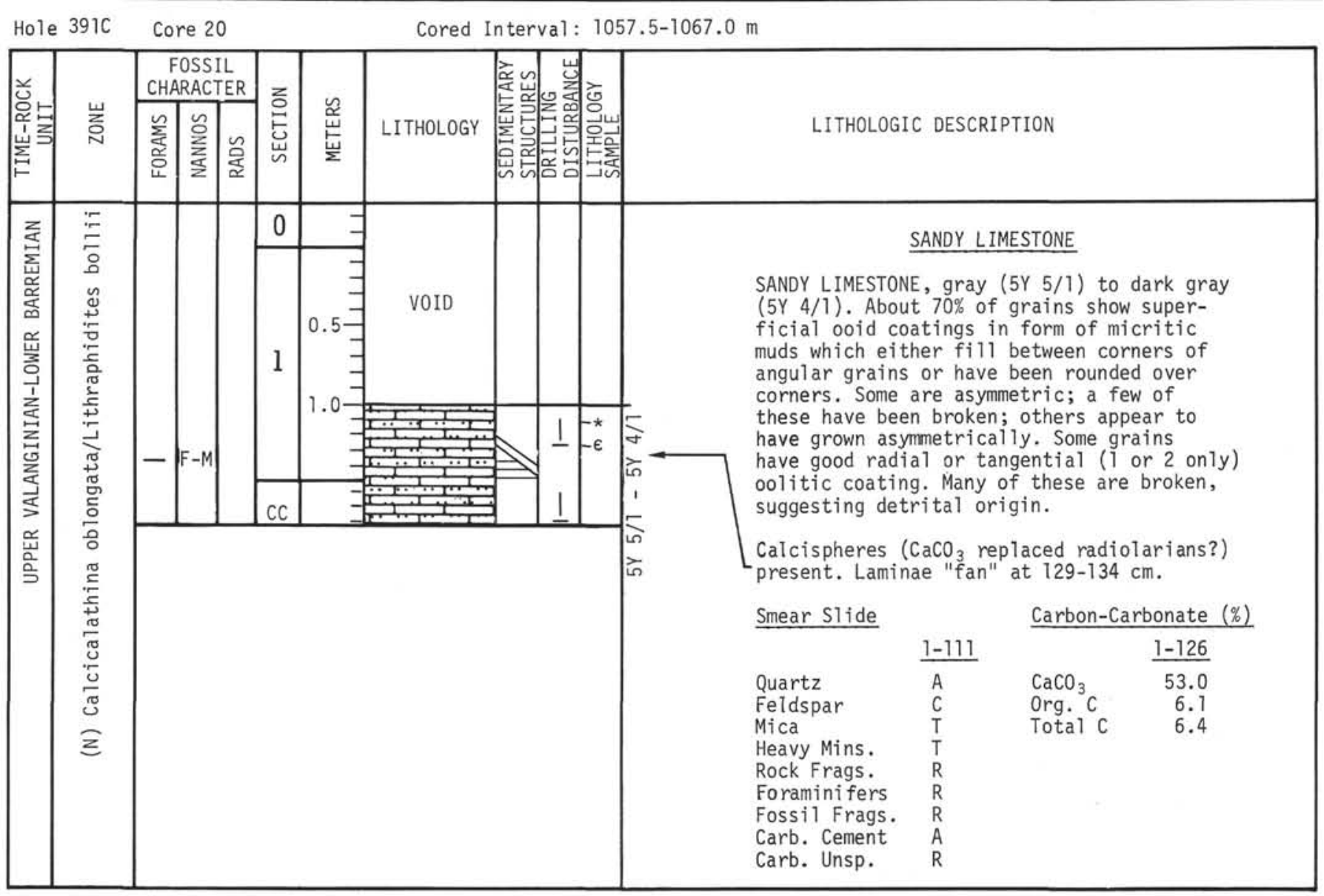




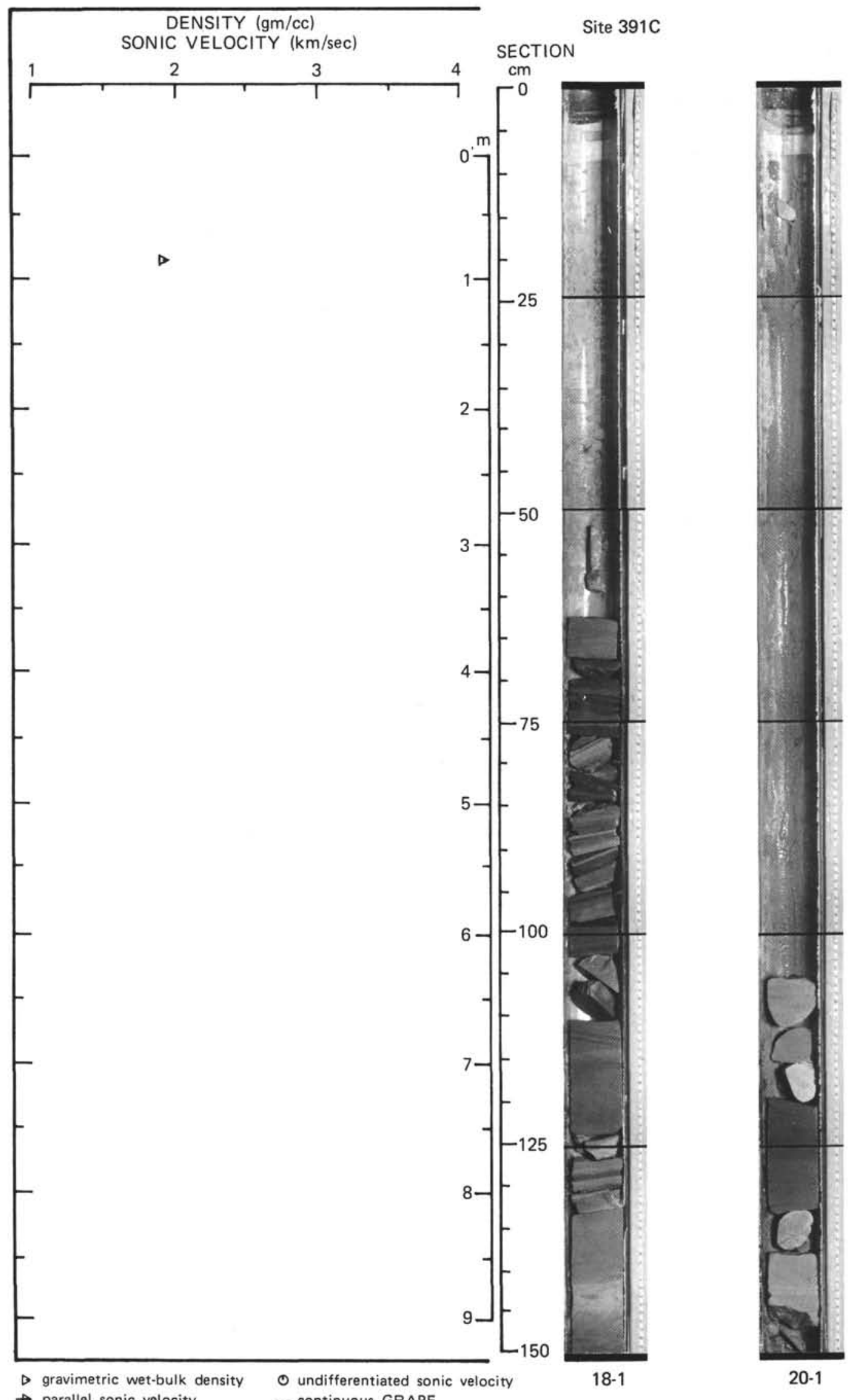


Hole 391C Core 21 Cored Interval: 1086.0-1095.5 m

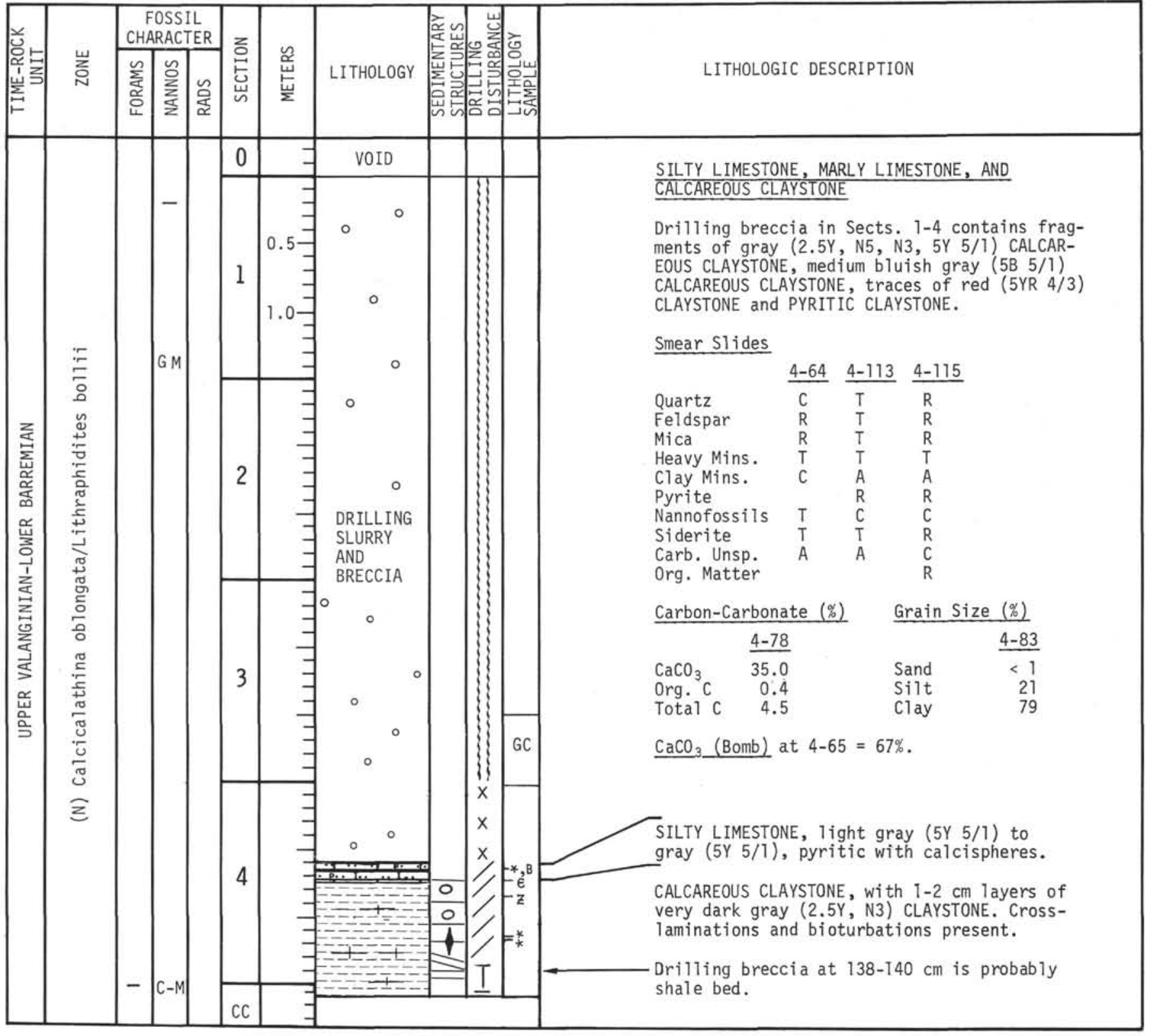

Hole $391 \mathrm{C}$ Core 22

Cored Interval: 1095.5-1104.5 m

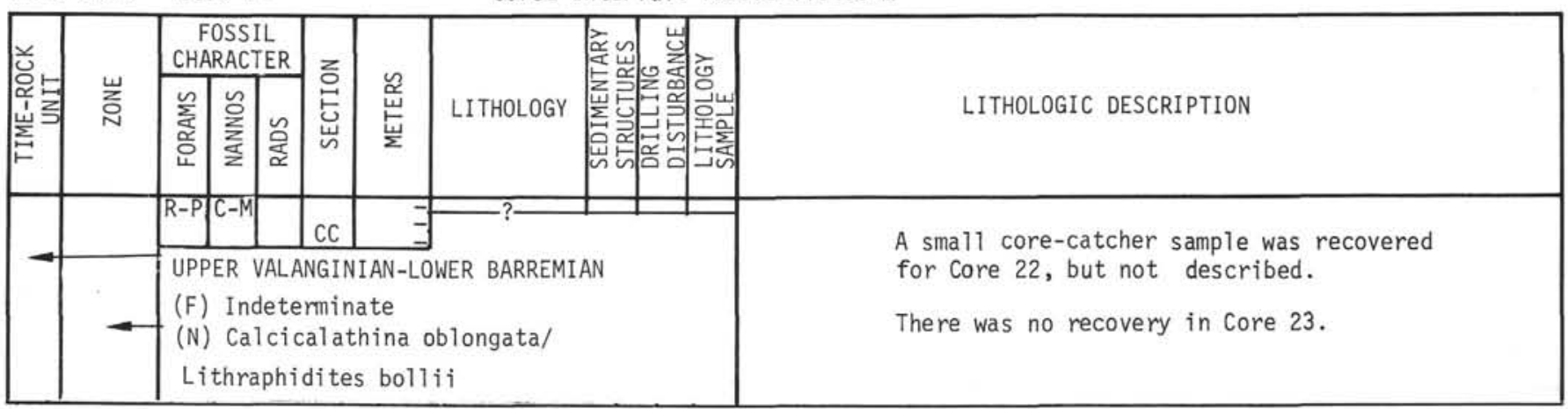




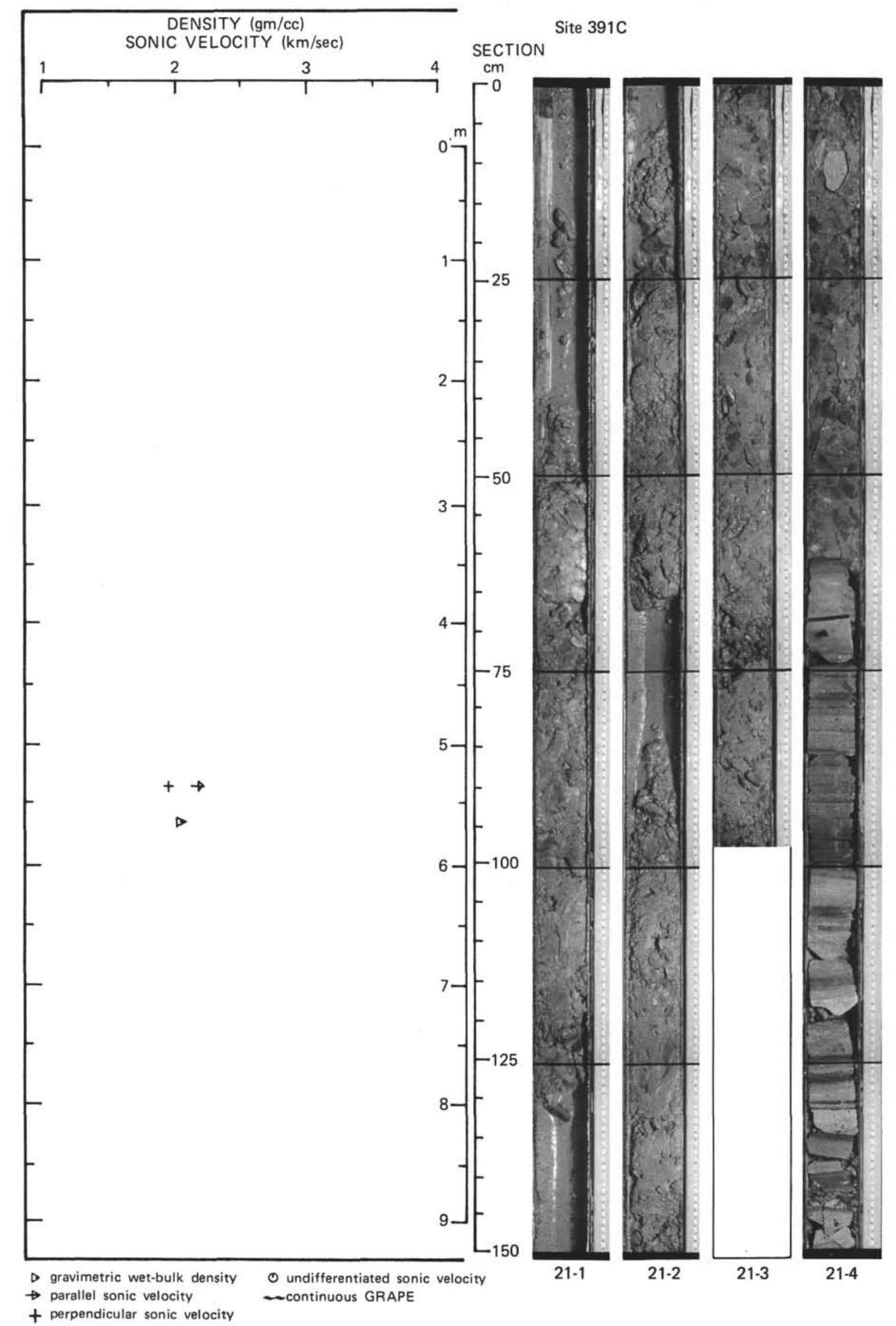




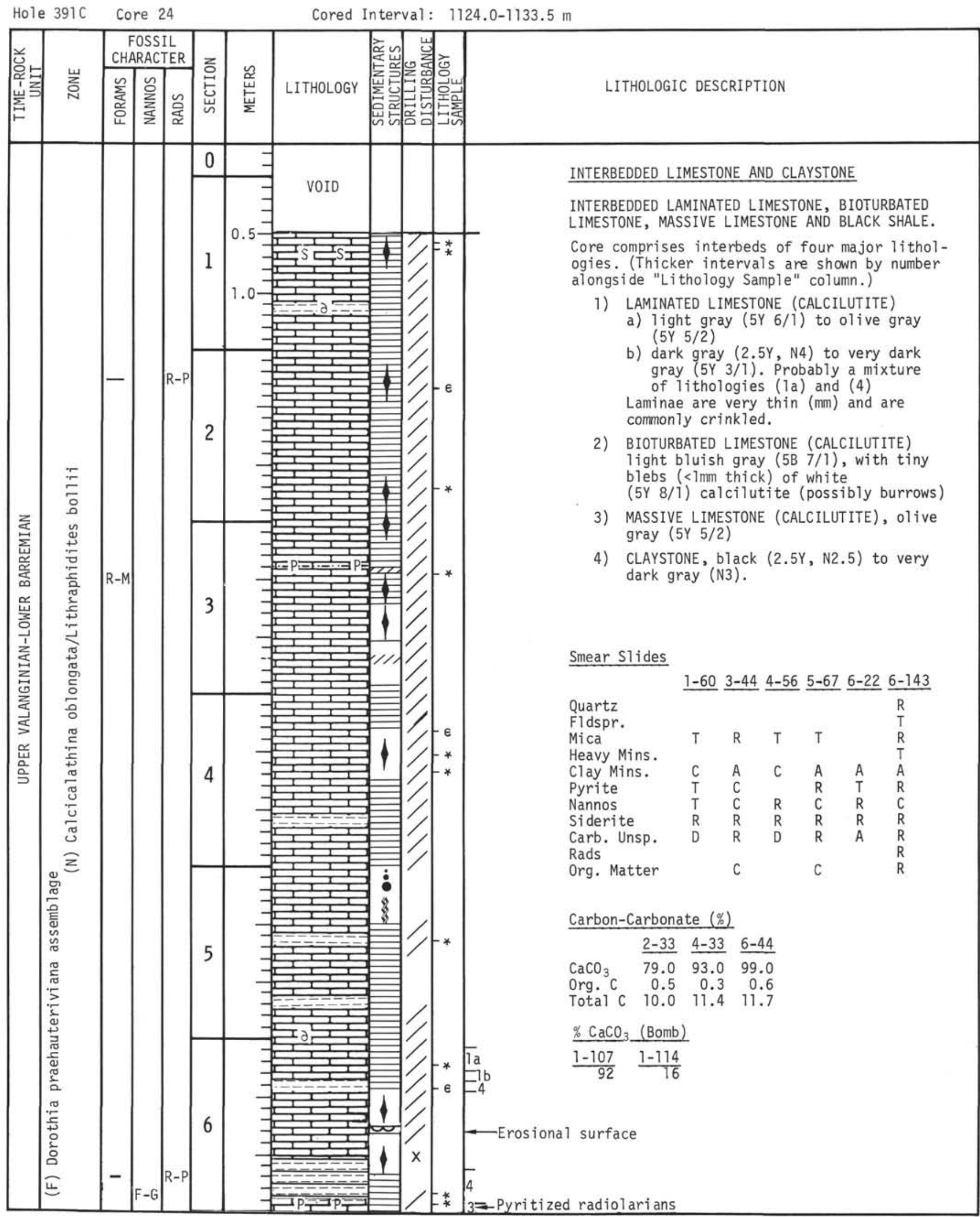




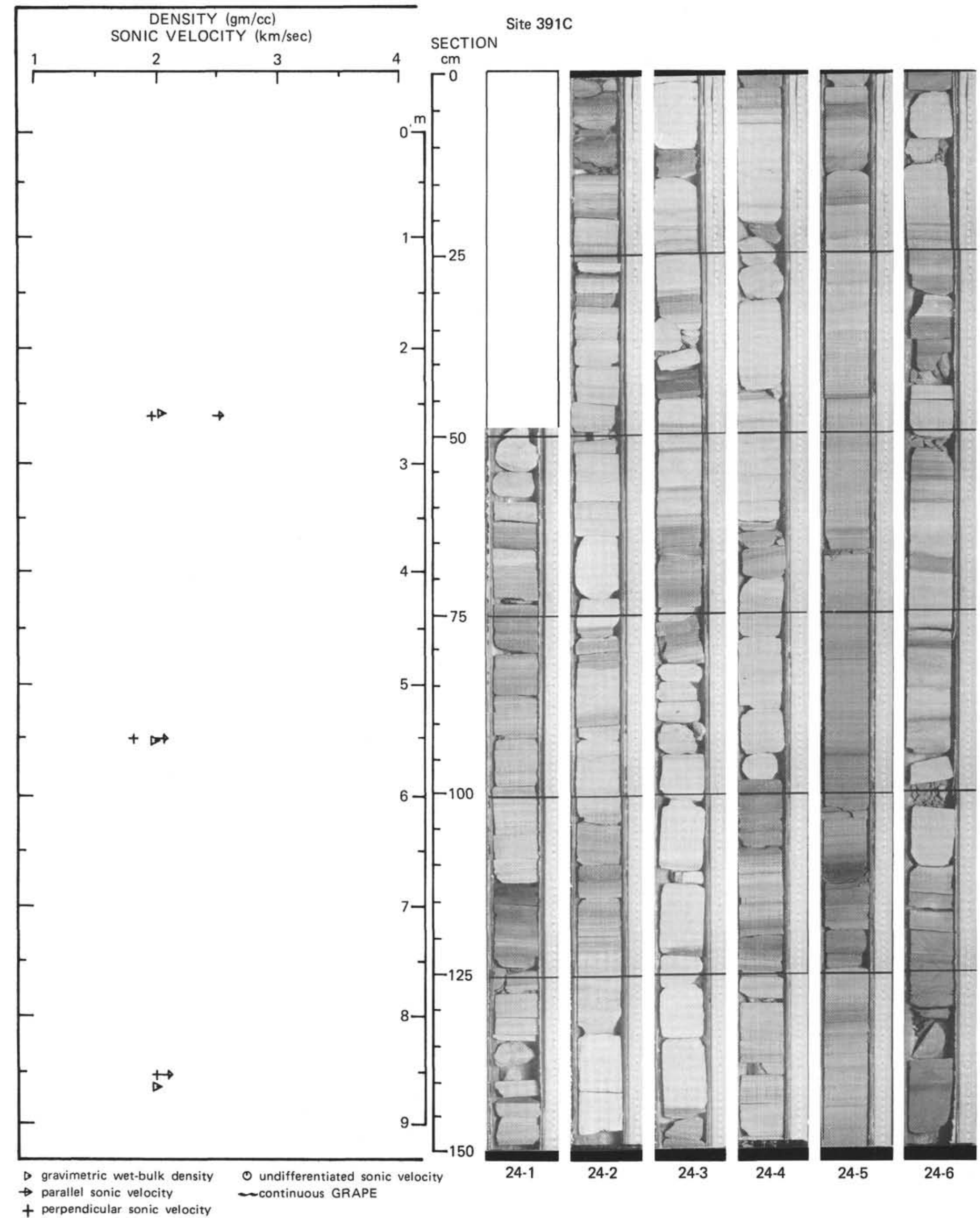


Hole 391C Core $25 \quad$ Cored Interval: 1133.5-1143.0 m

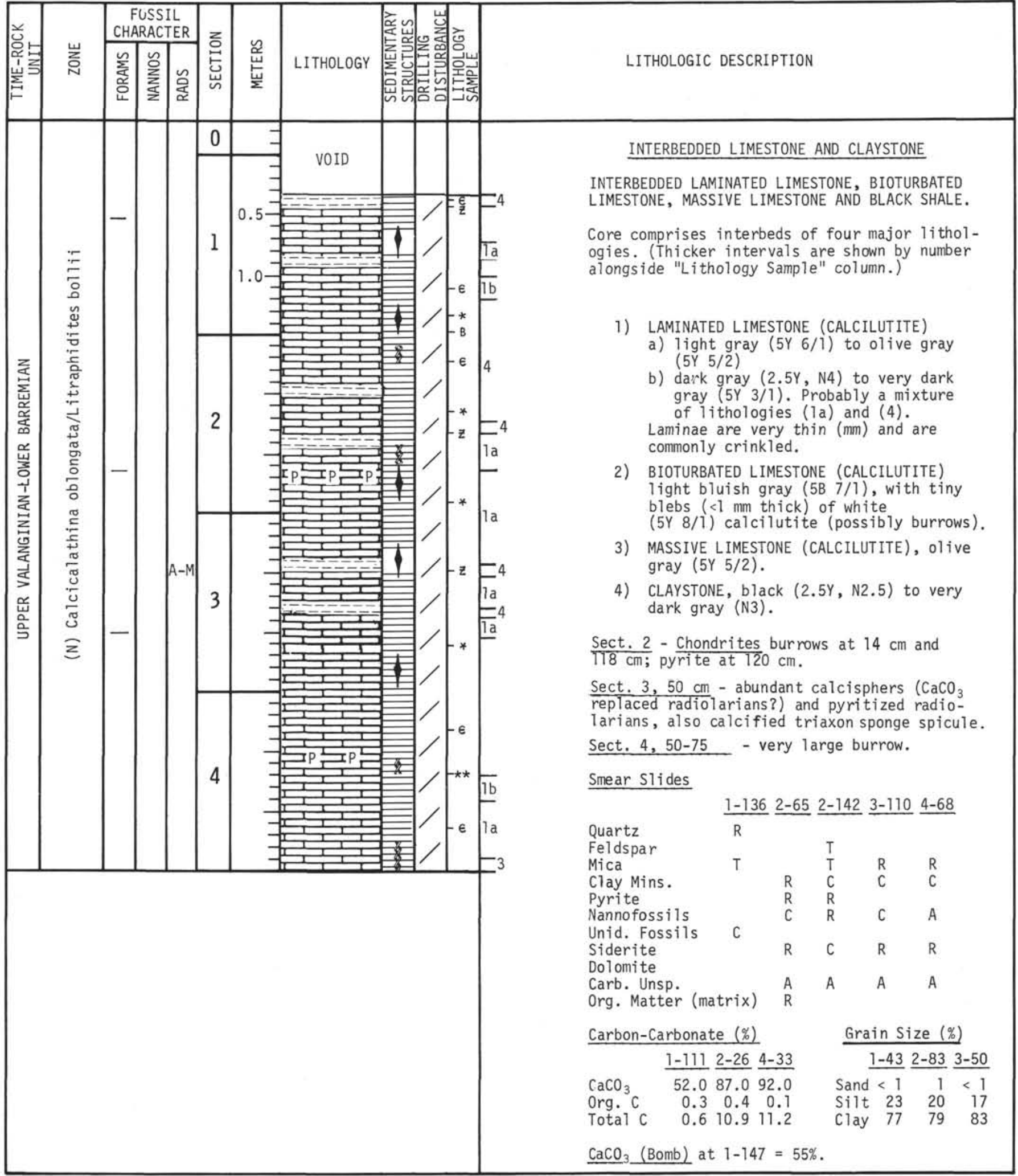




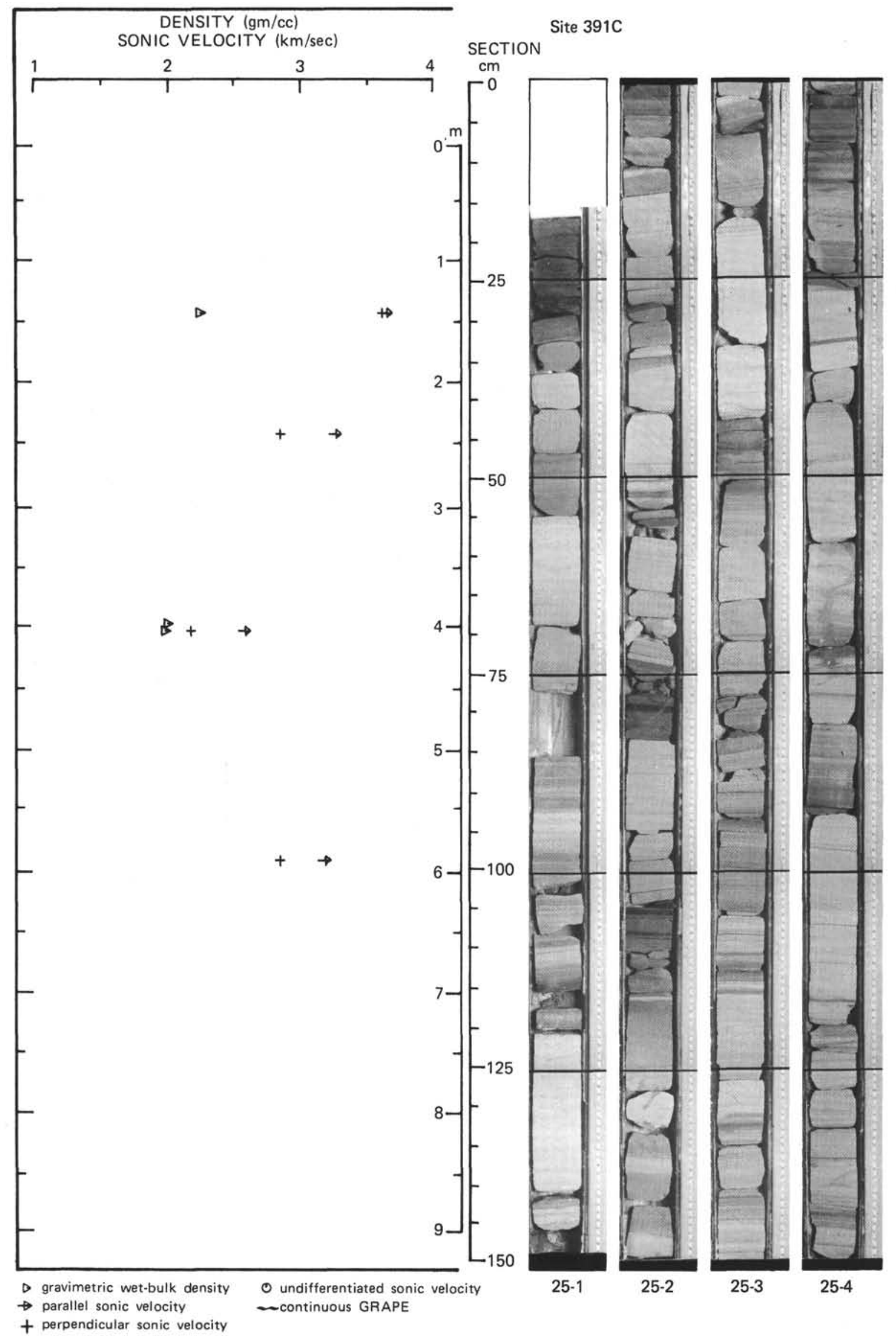




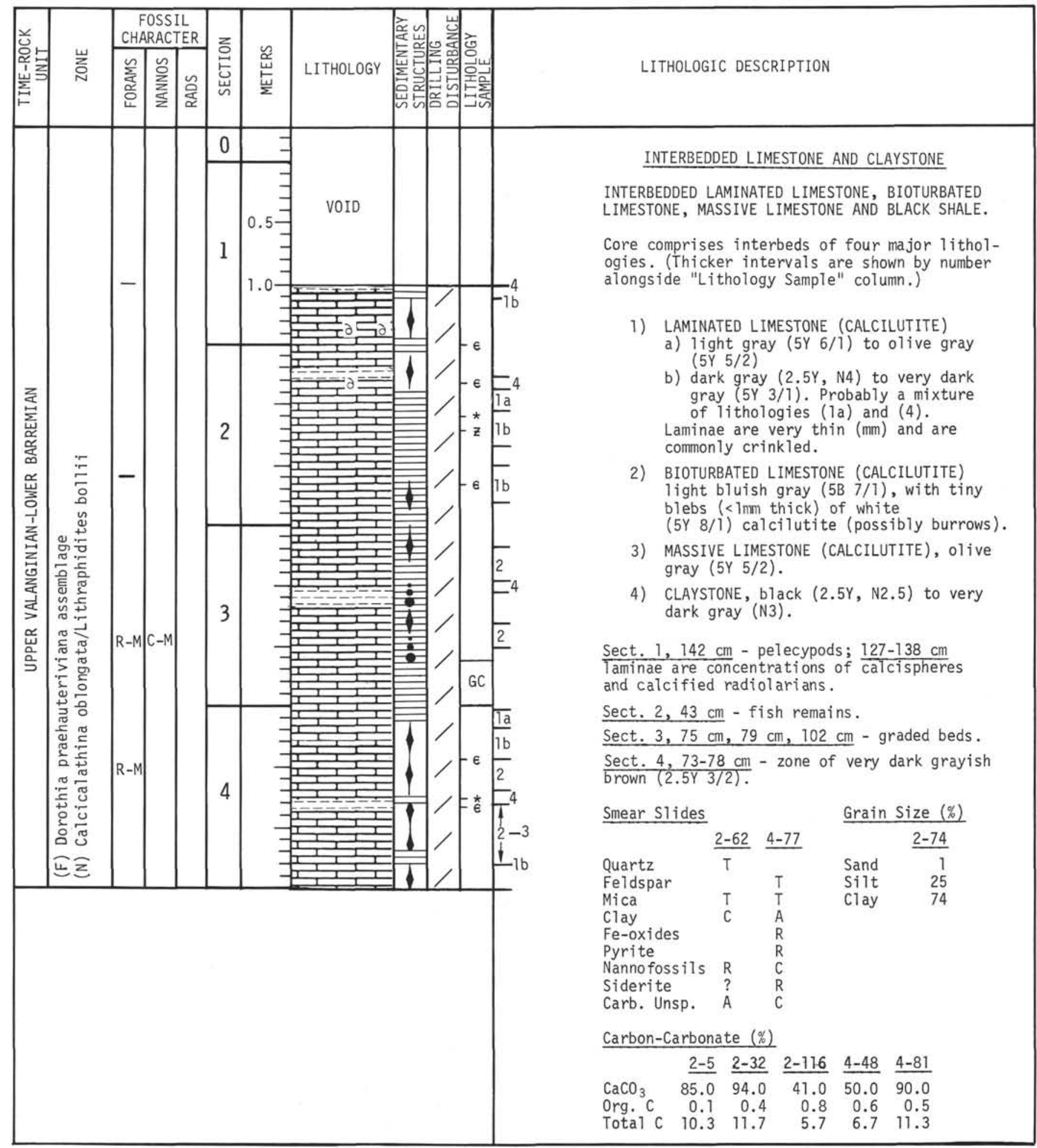




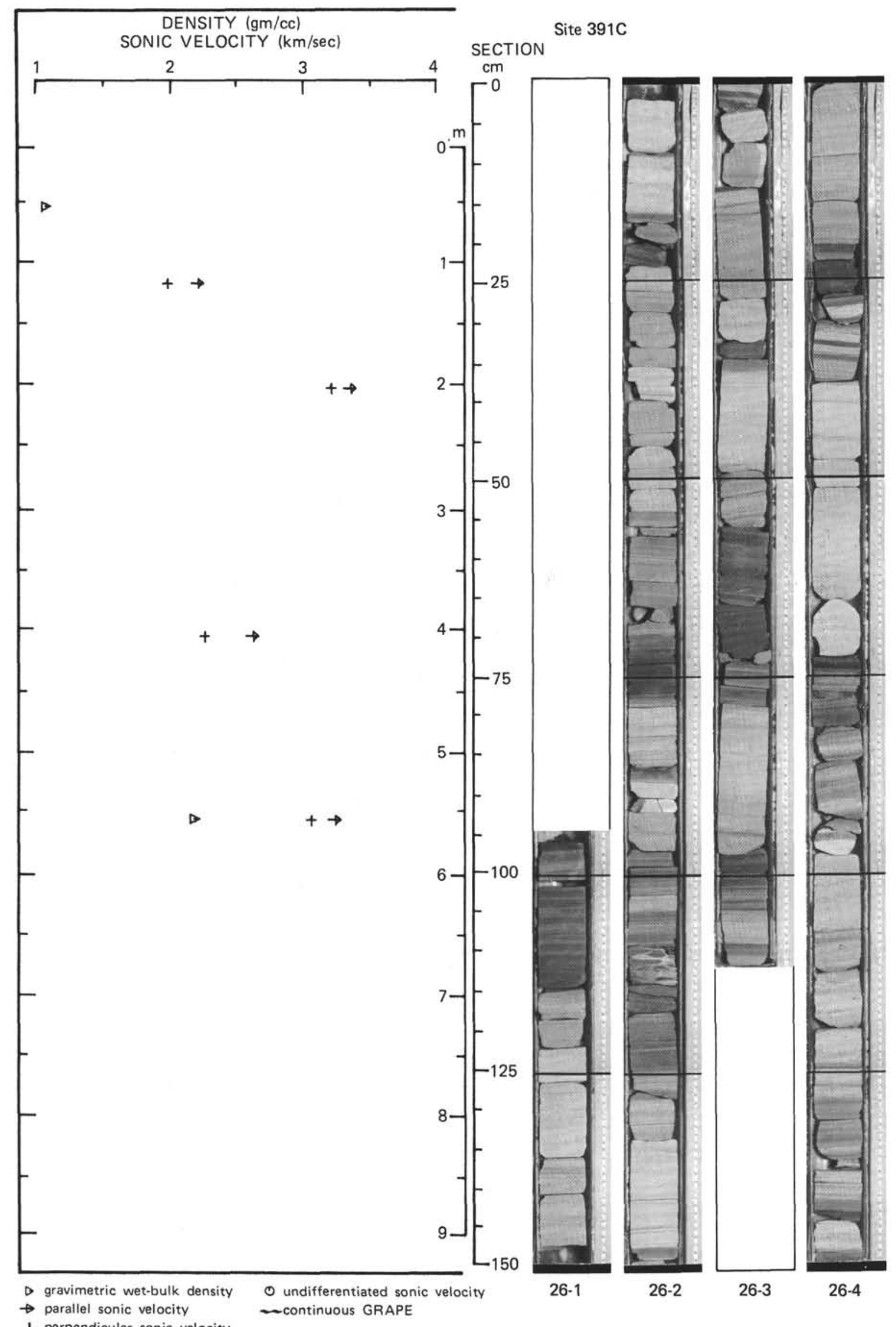




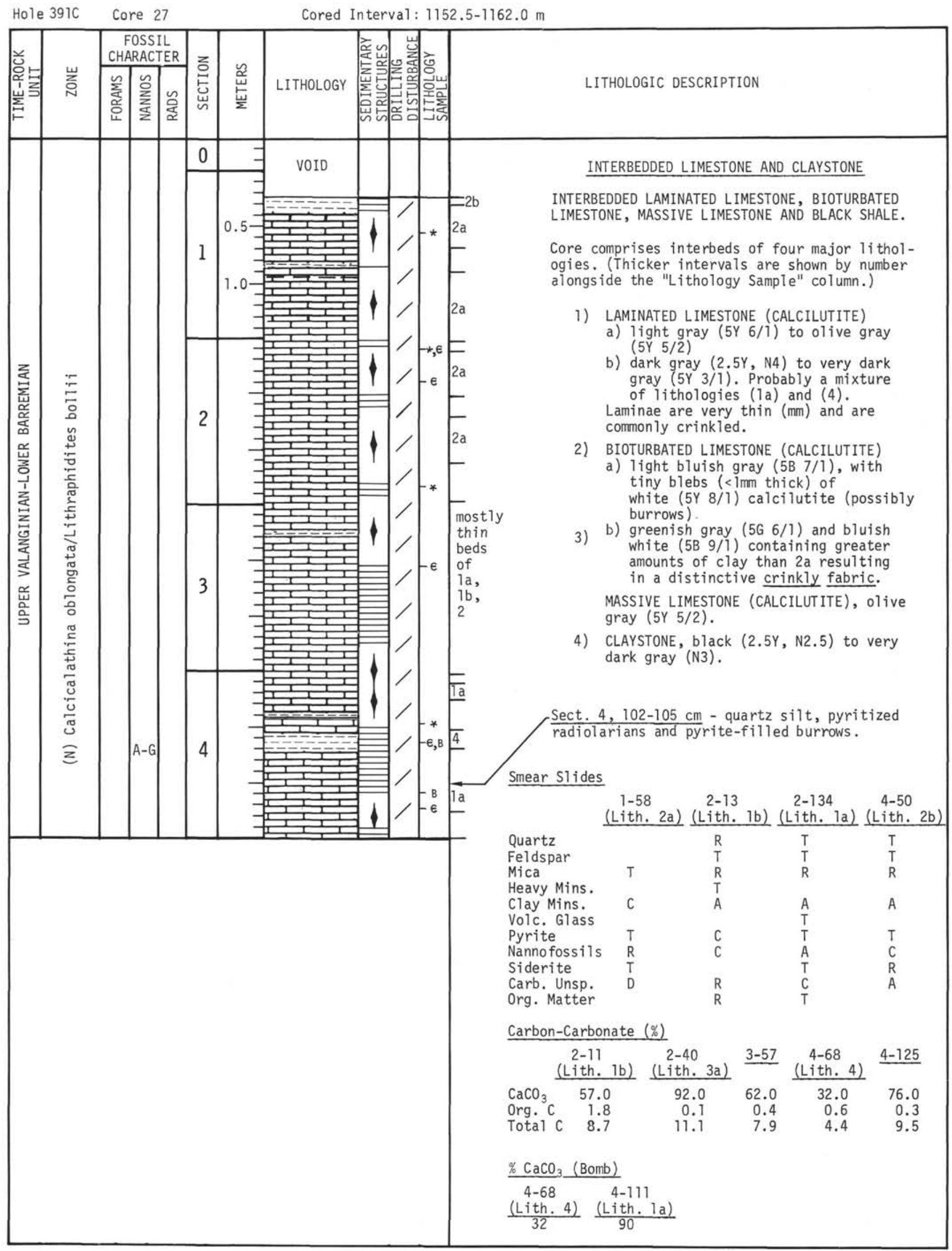




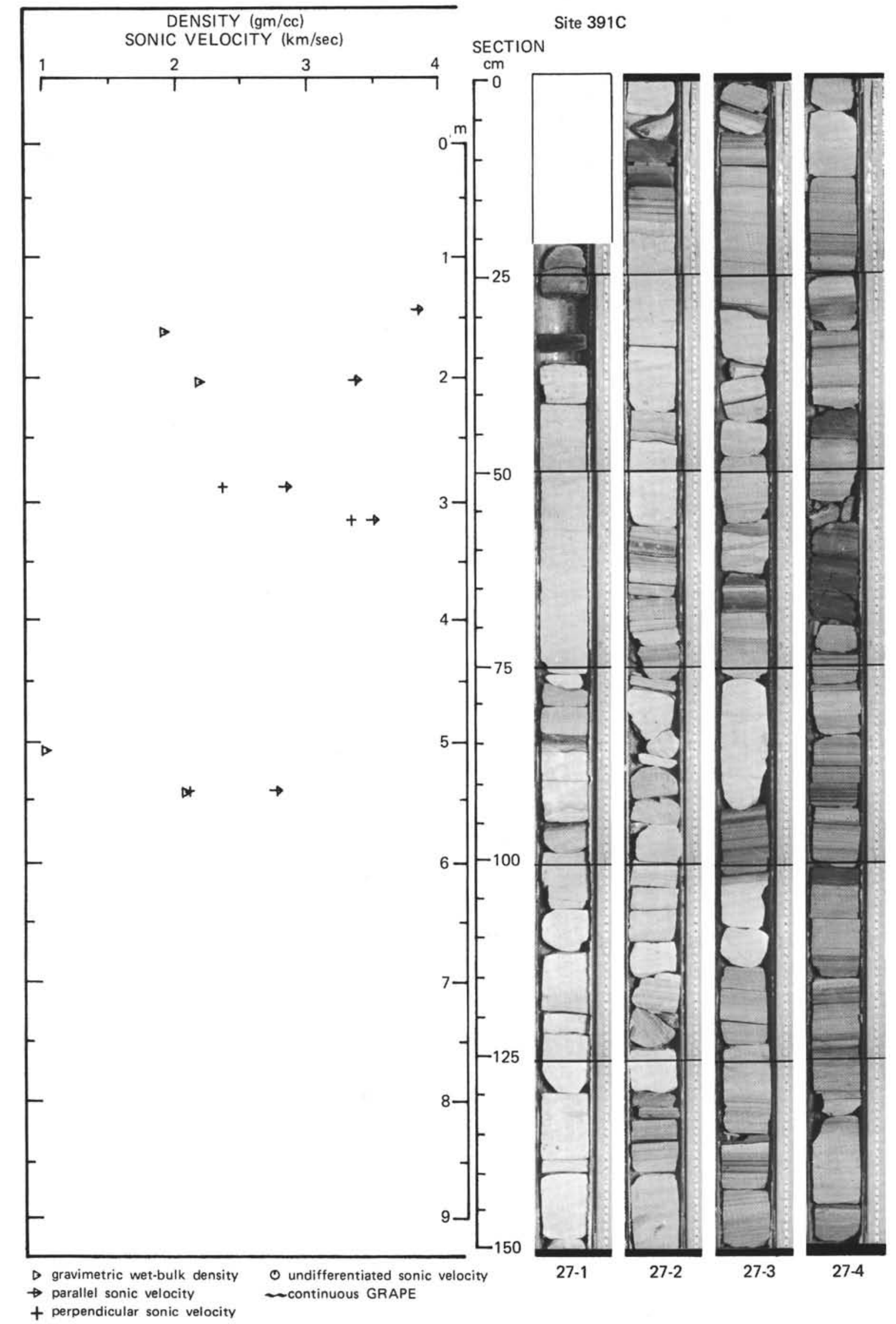




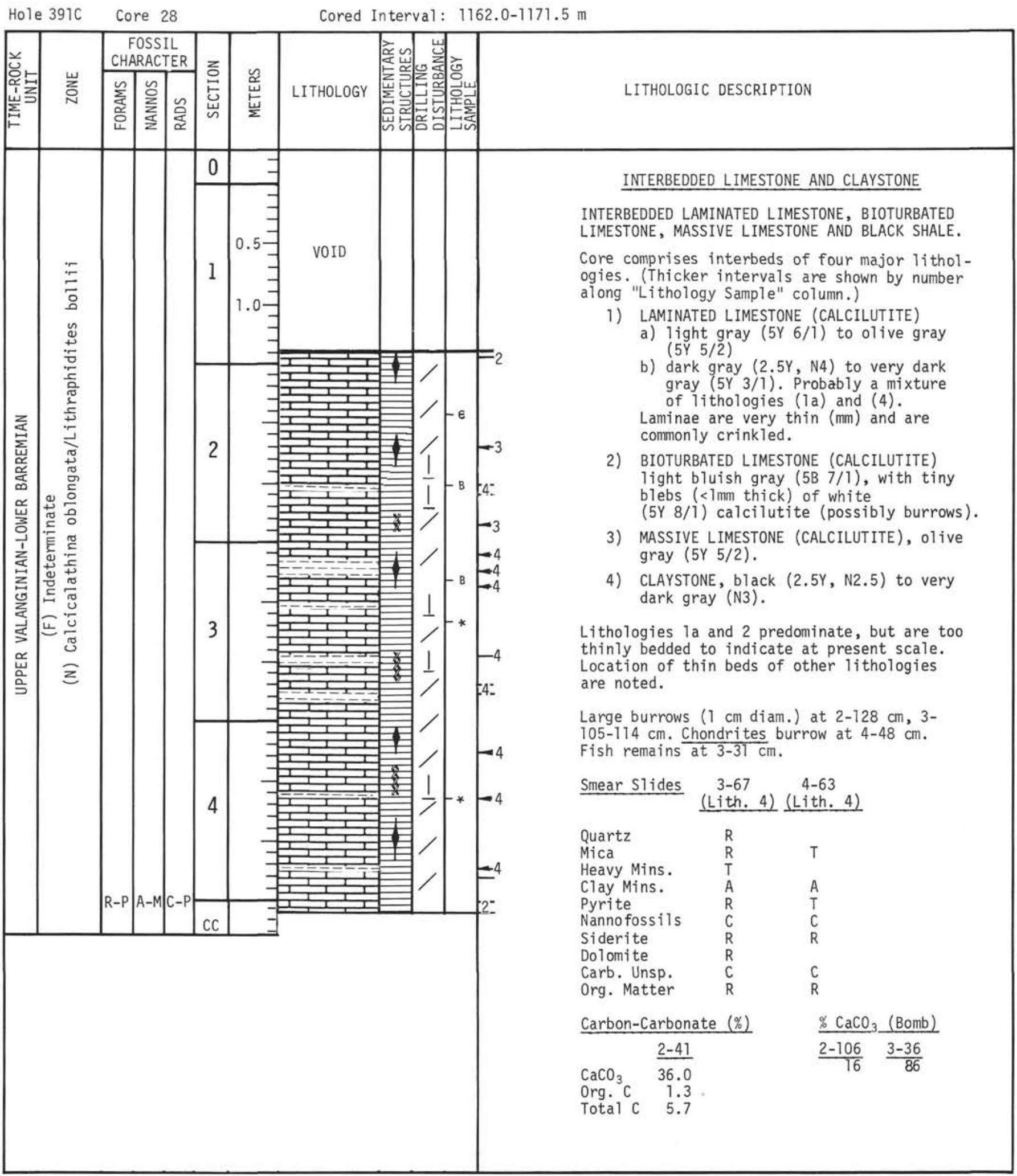


Hole 3910 Core 29

Cored Interva1: 1171.5-1181.0 m

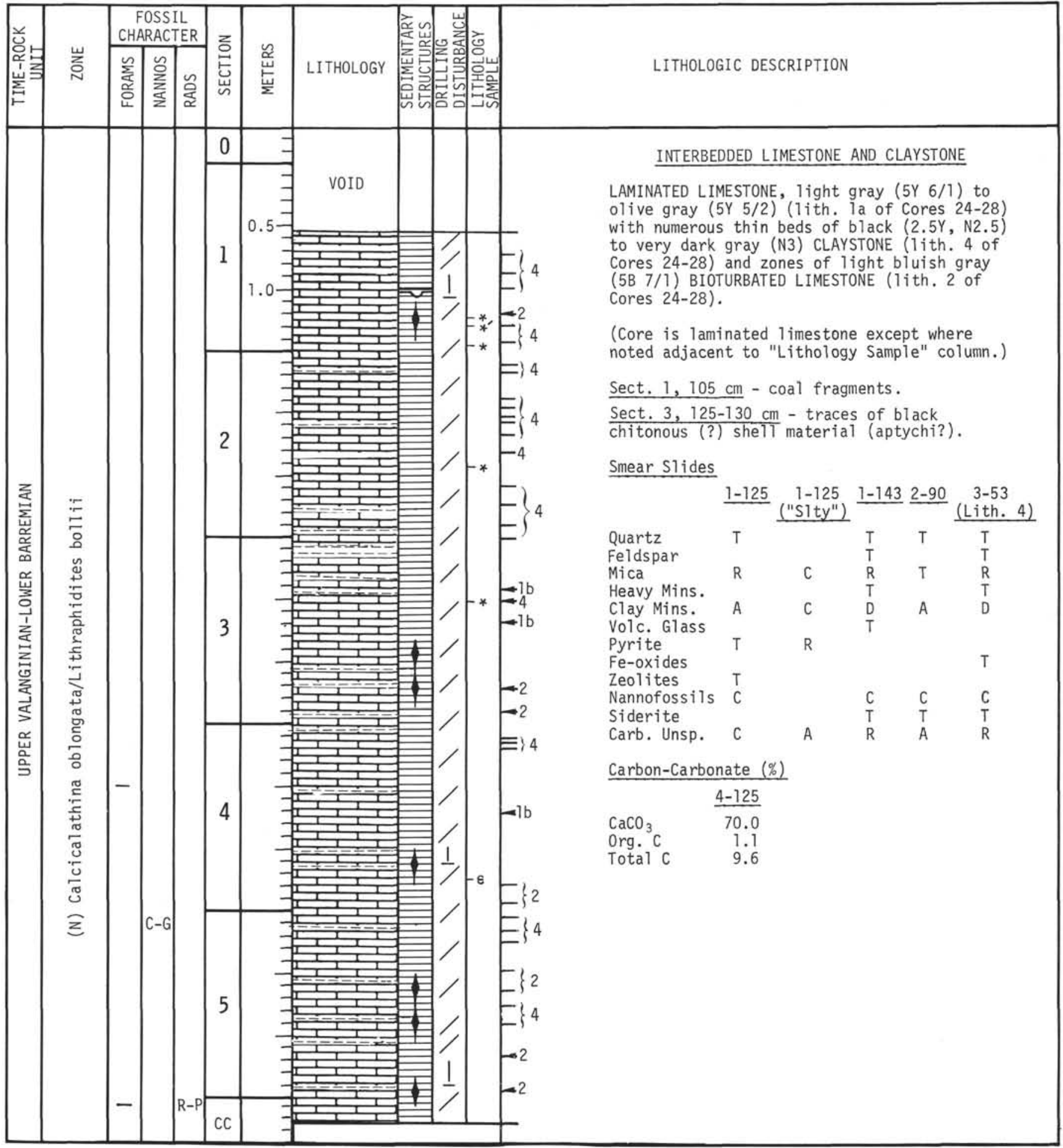


Hole $391 \mathrm{C}$ Core 30

Cored Interva1: 1181.0-1190.5 m

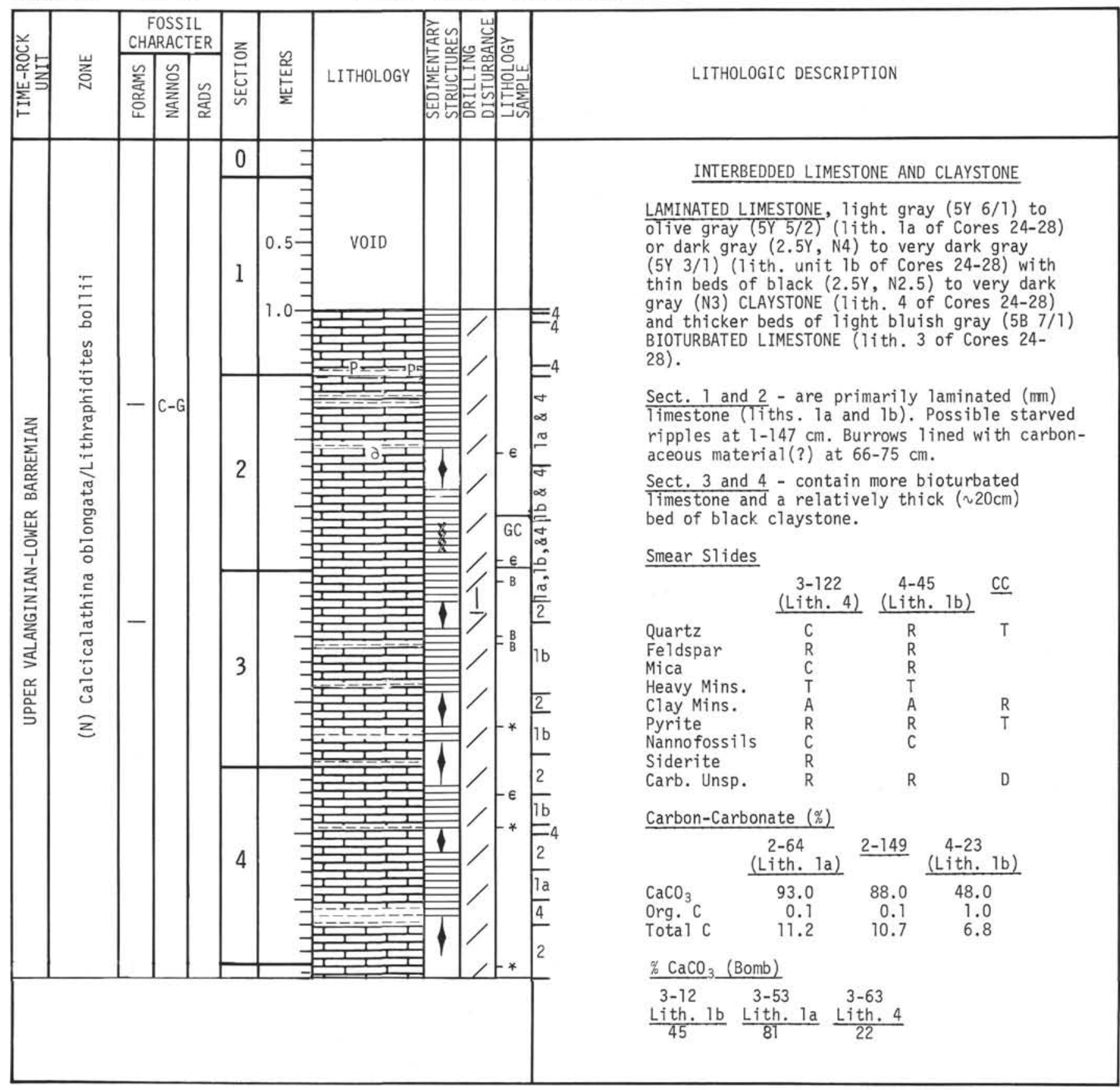




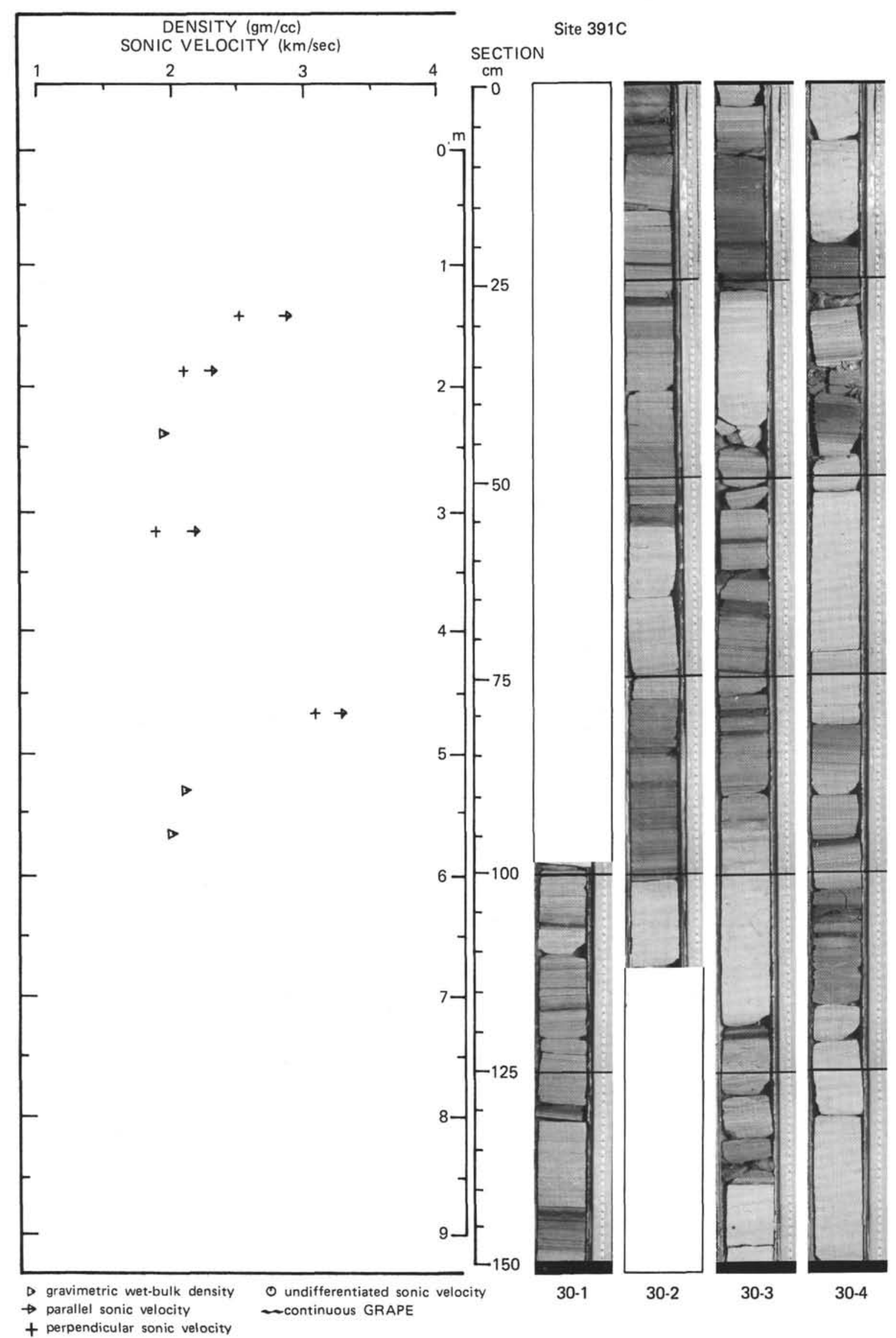




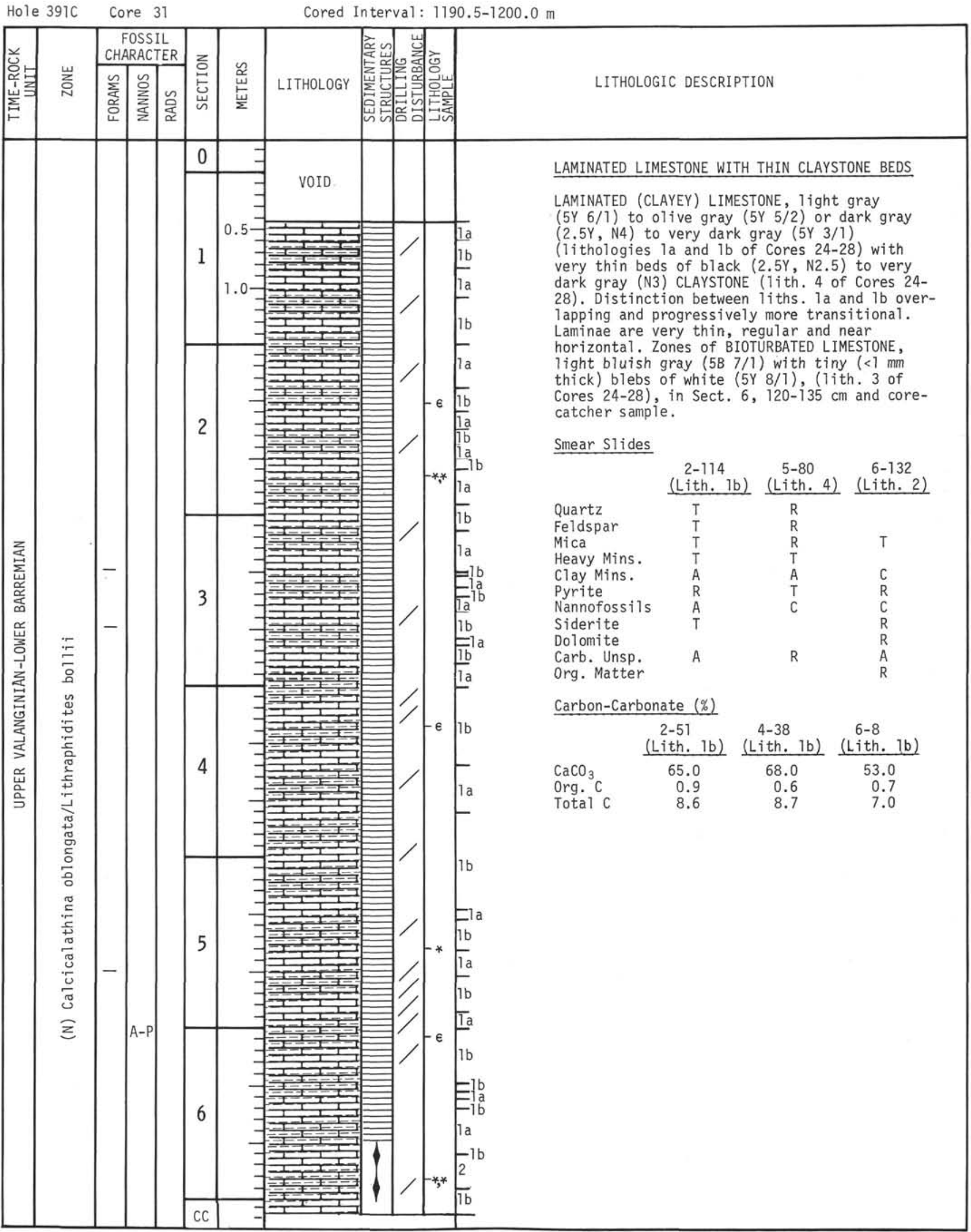




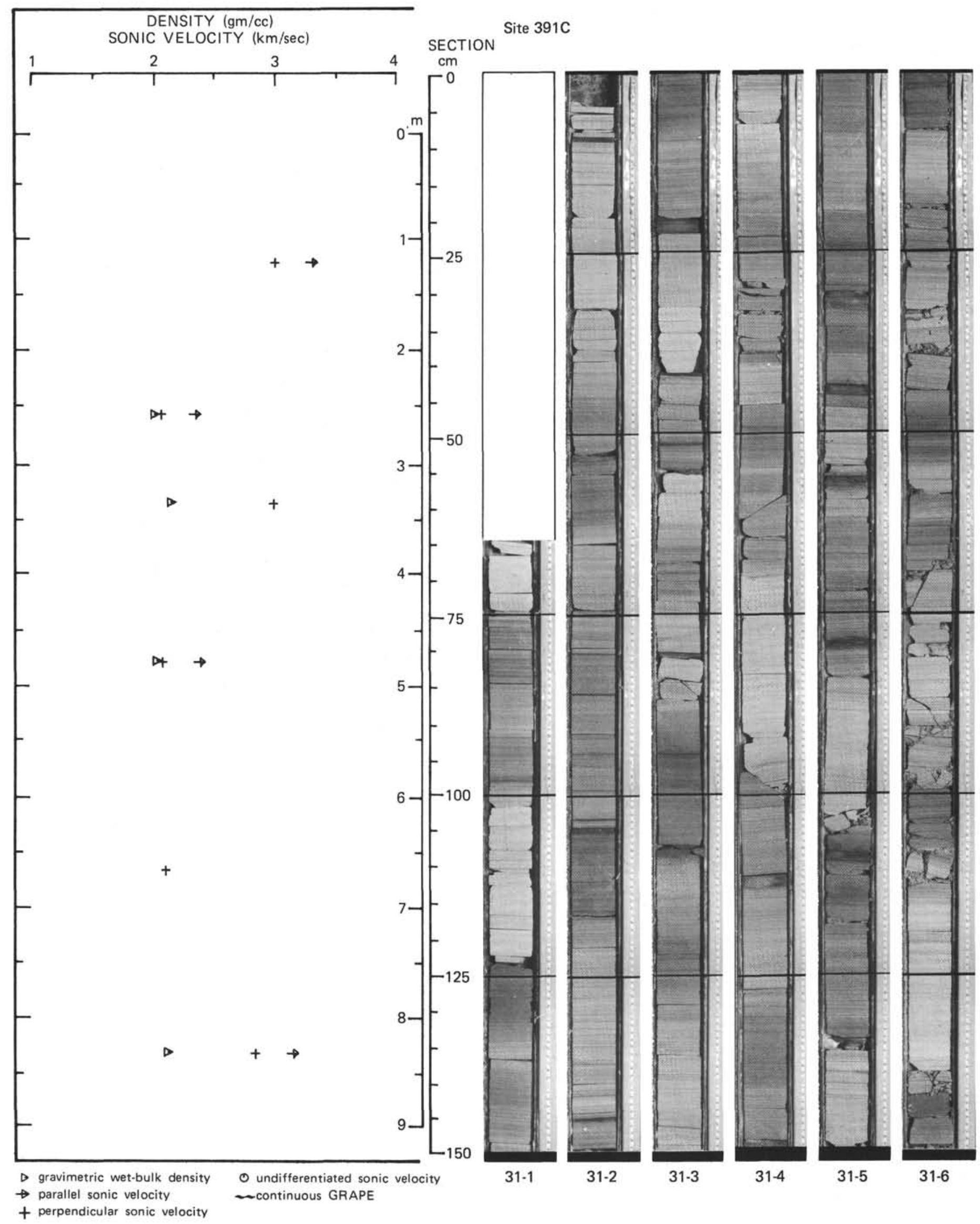




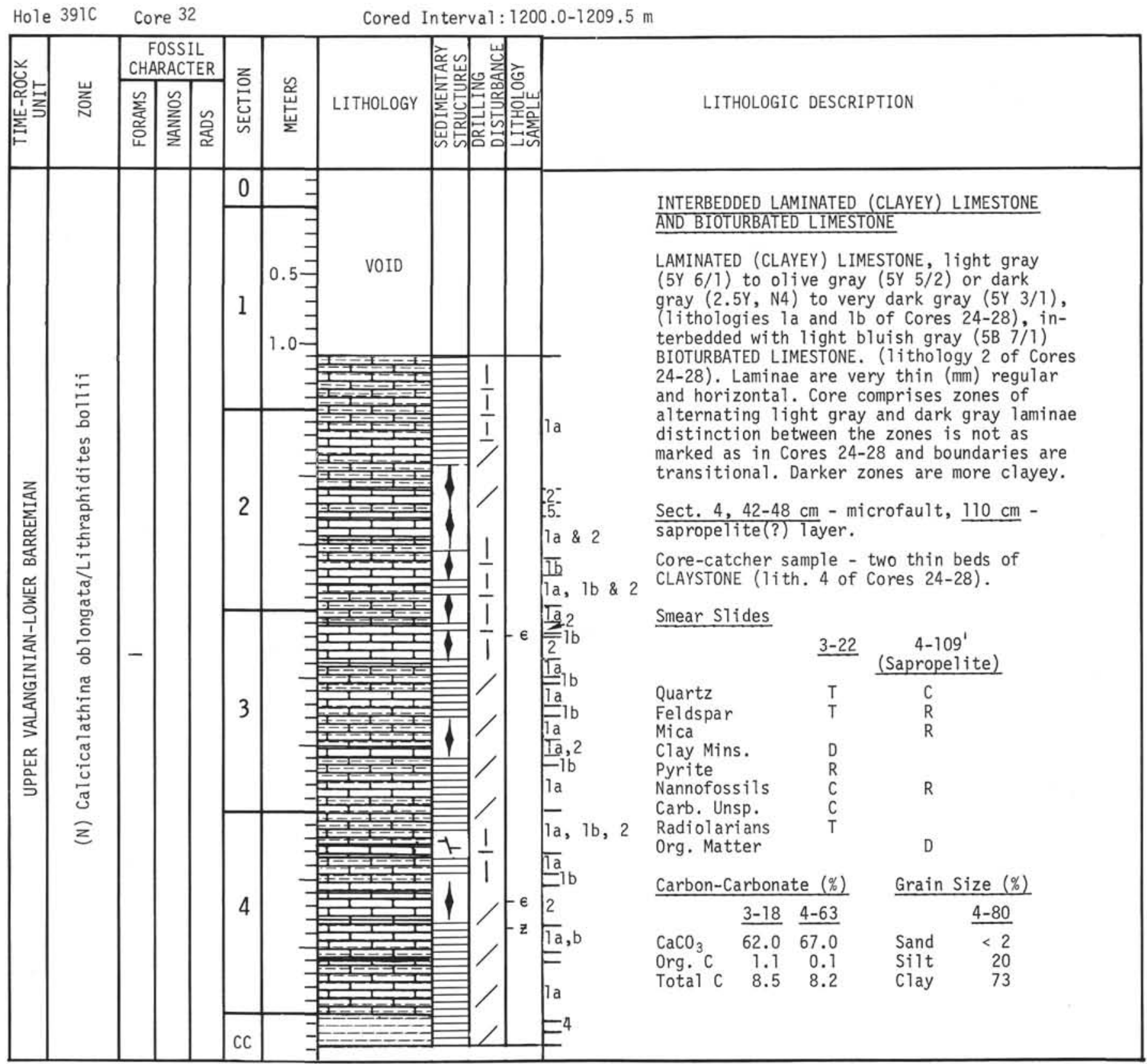




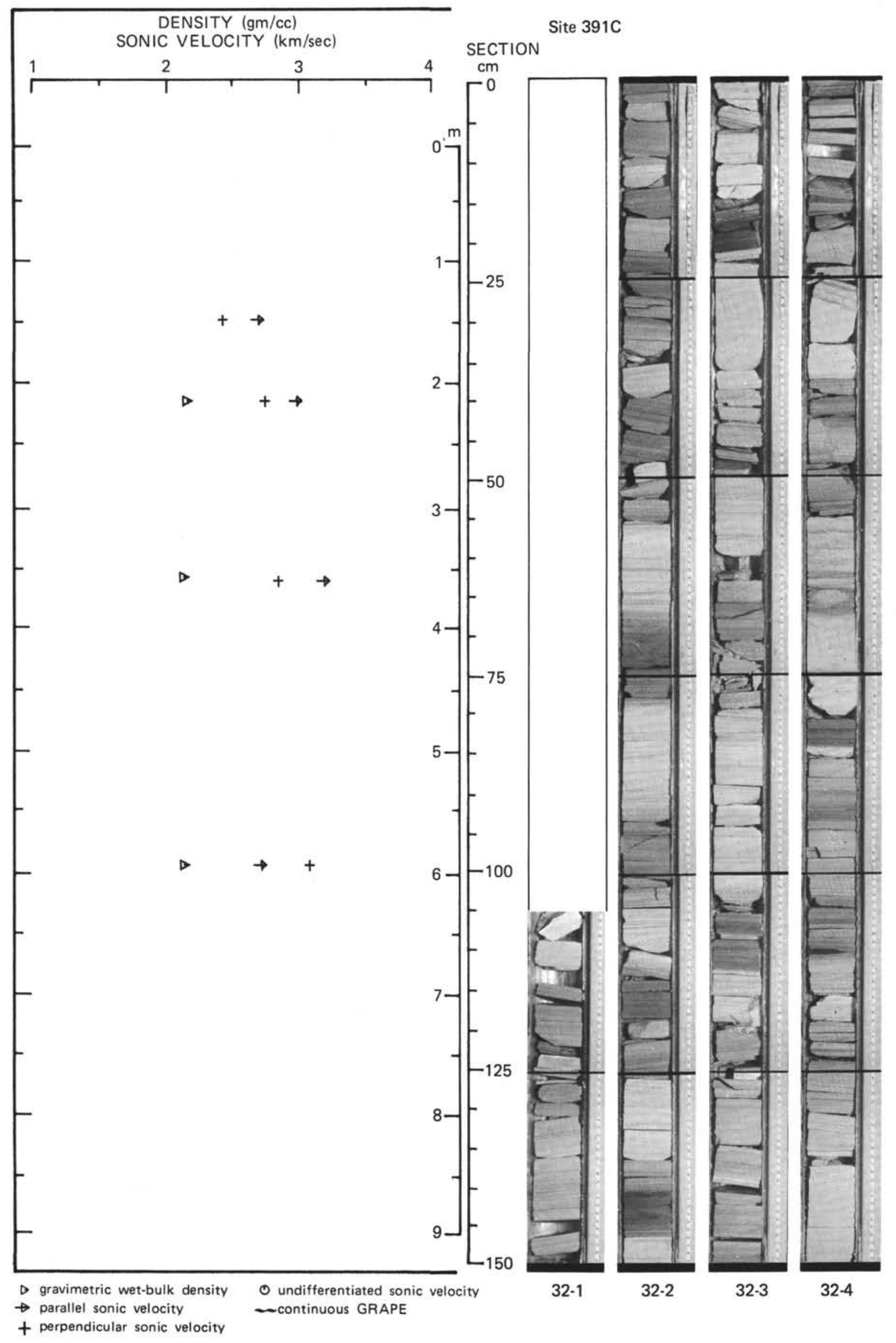




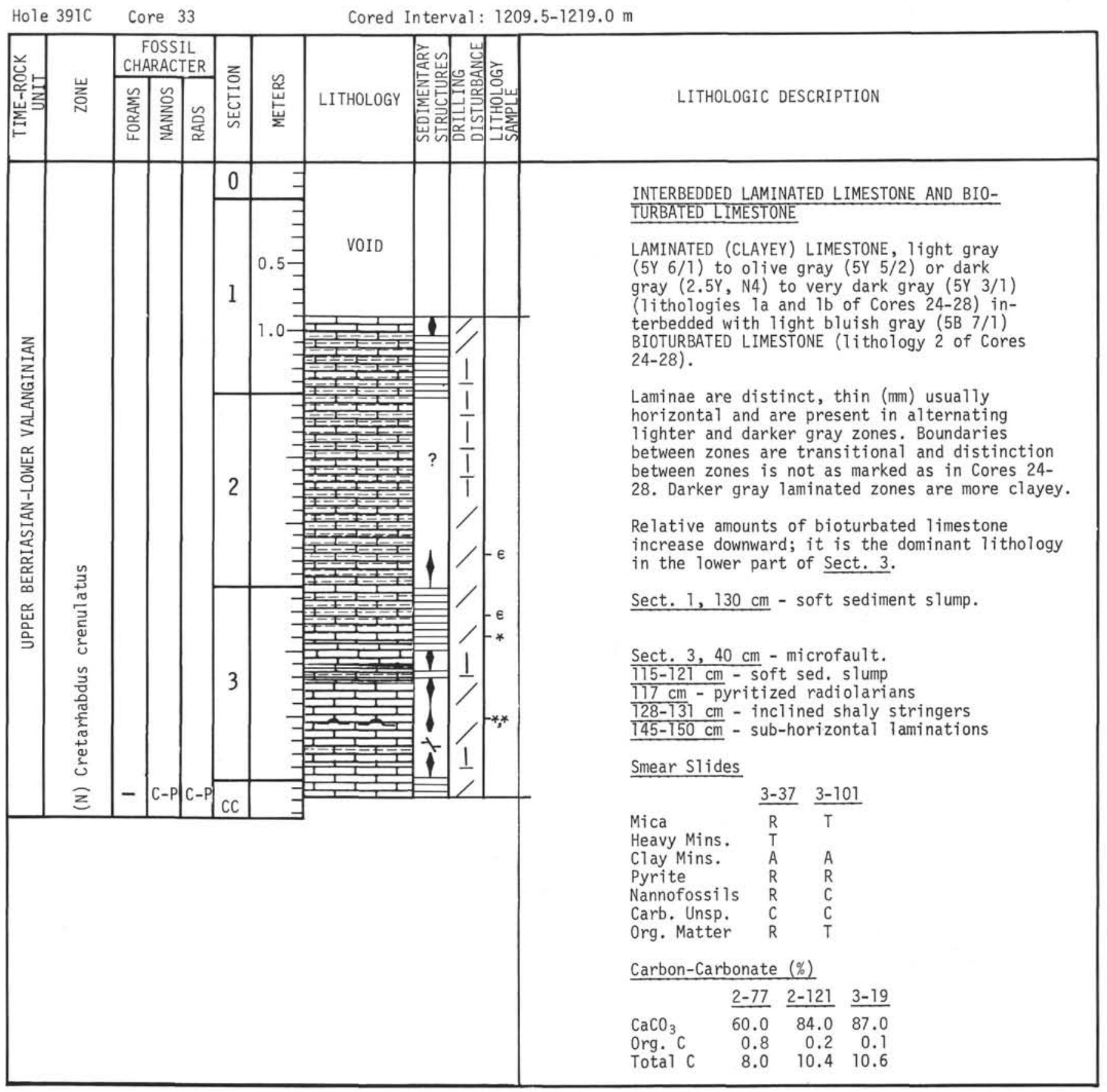




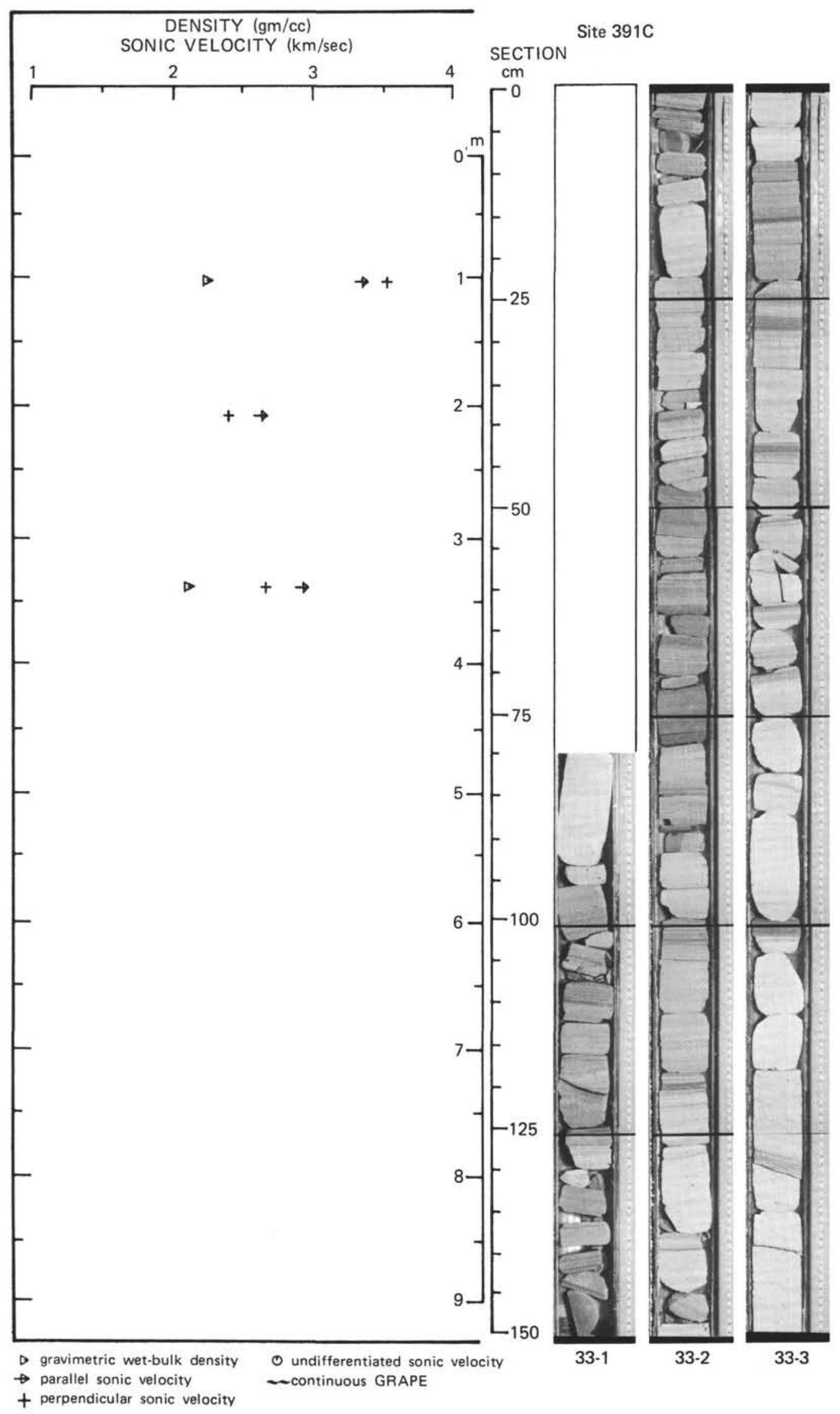




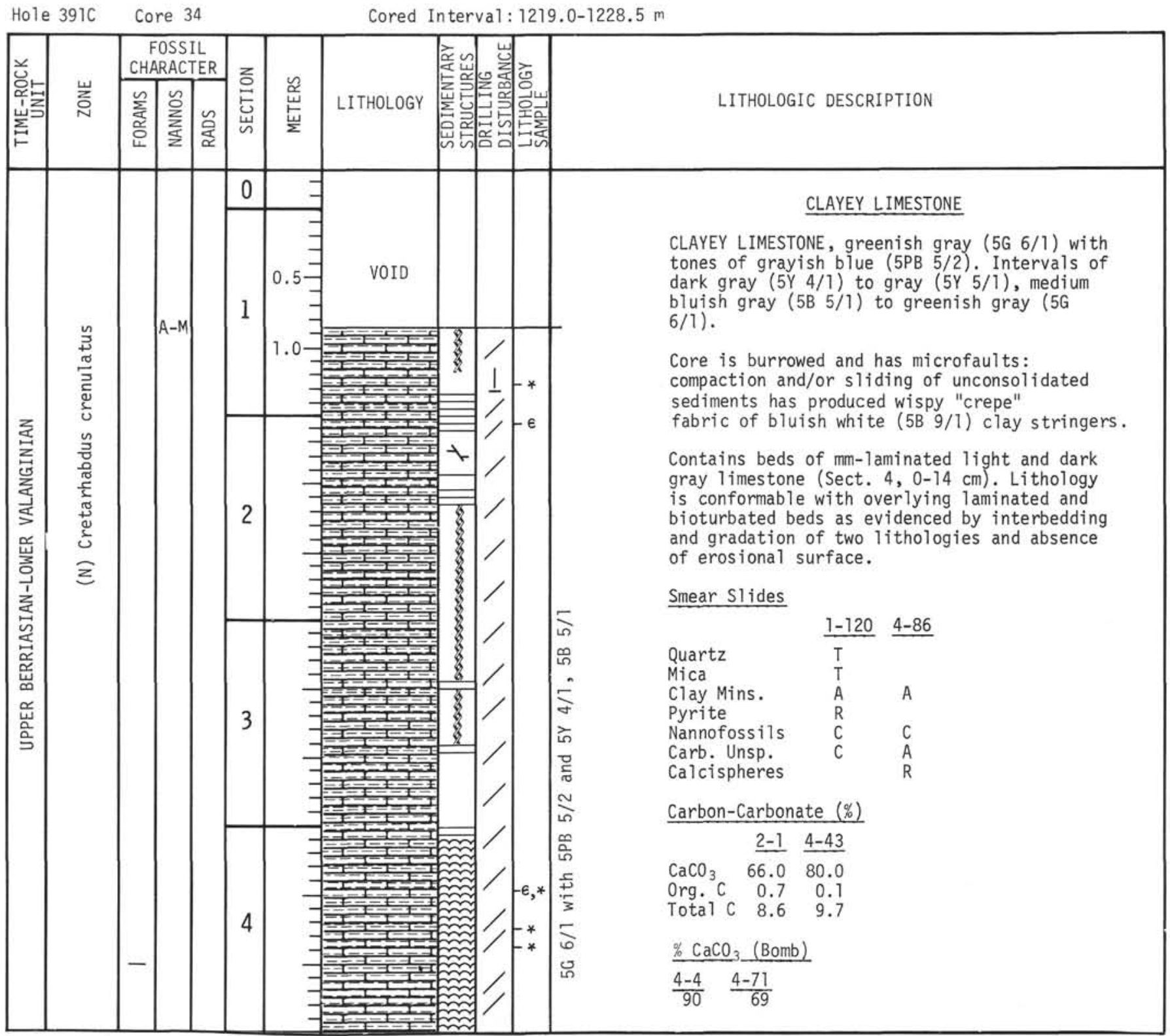




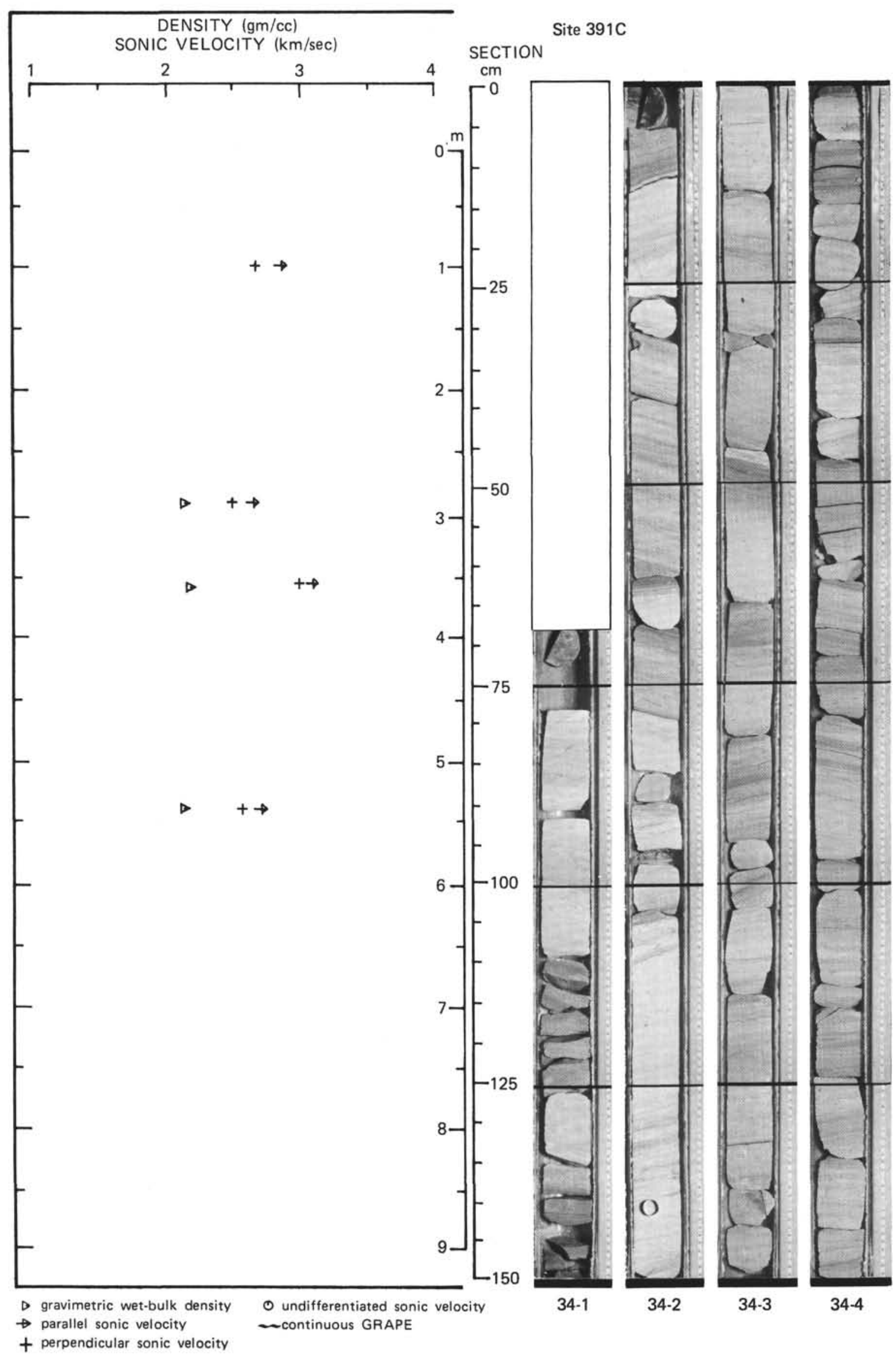


Hole 391C Core 35

Cored Interval: 1228.5-1238.0 m

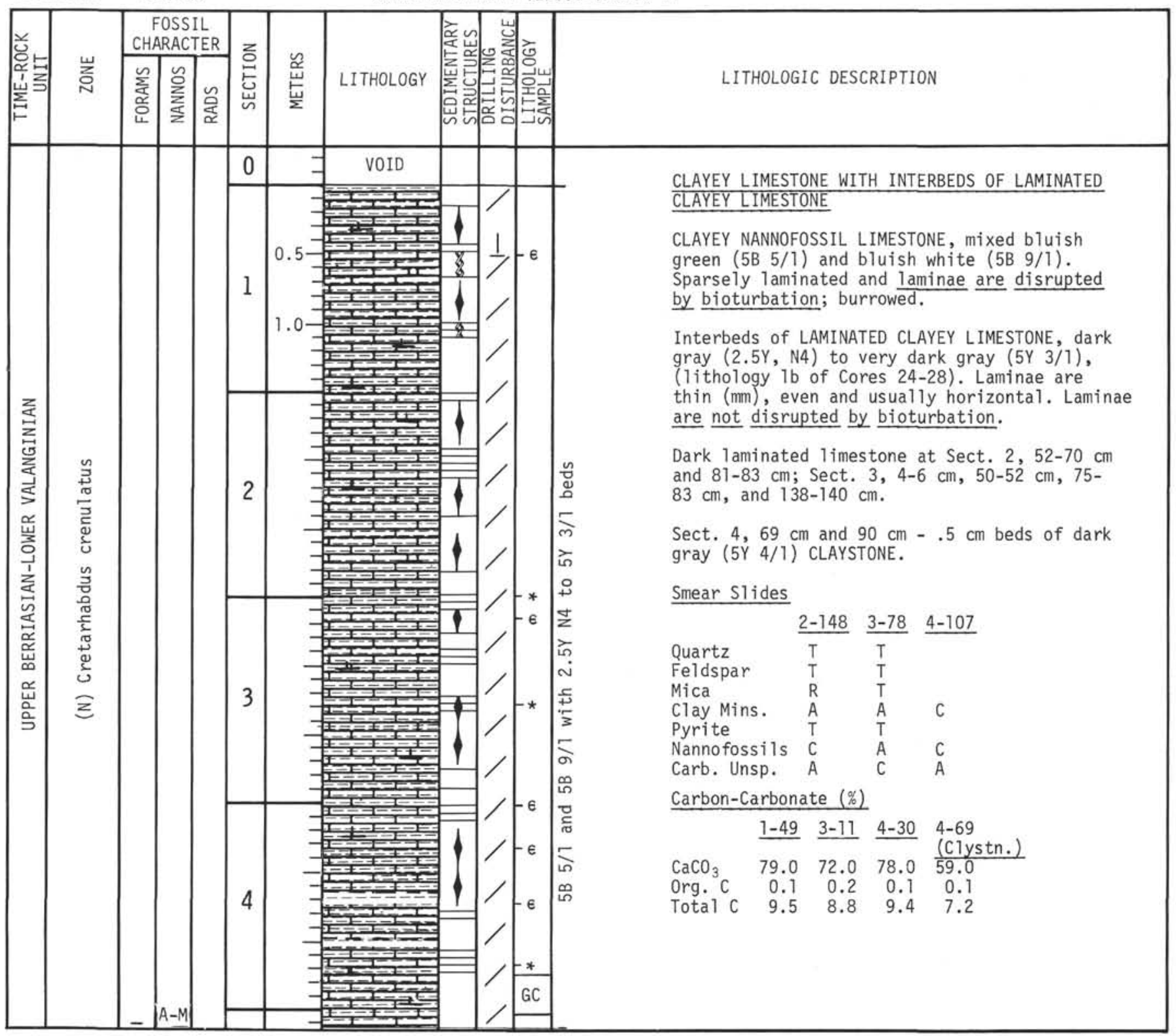




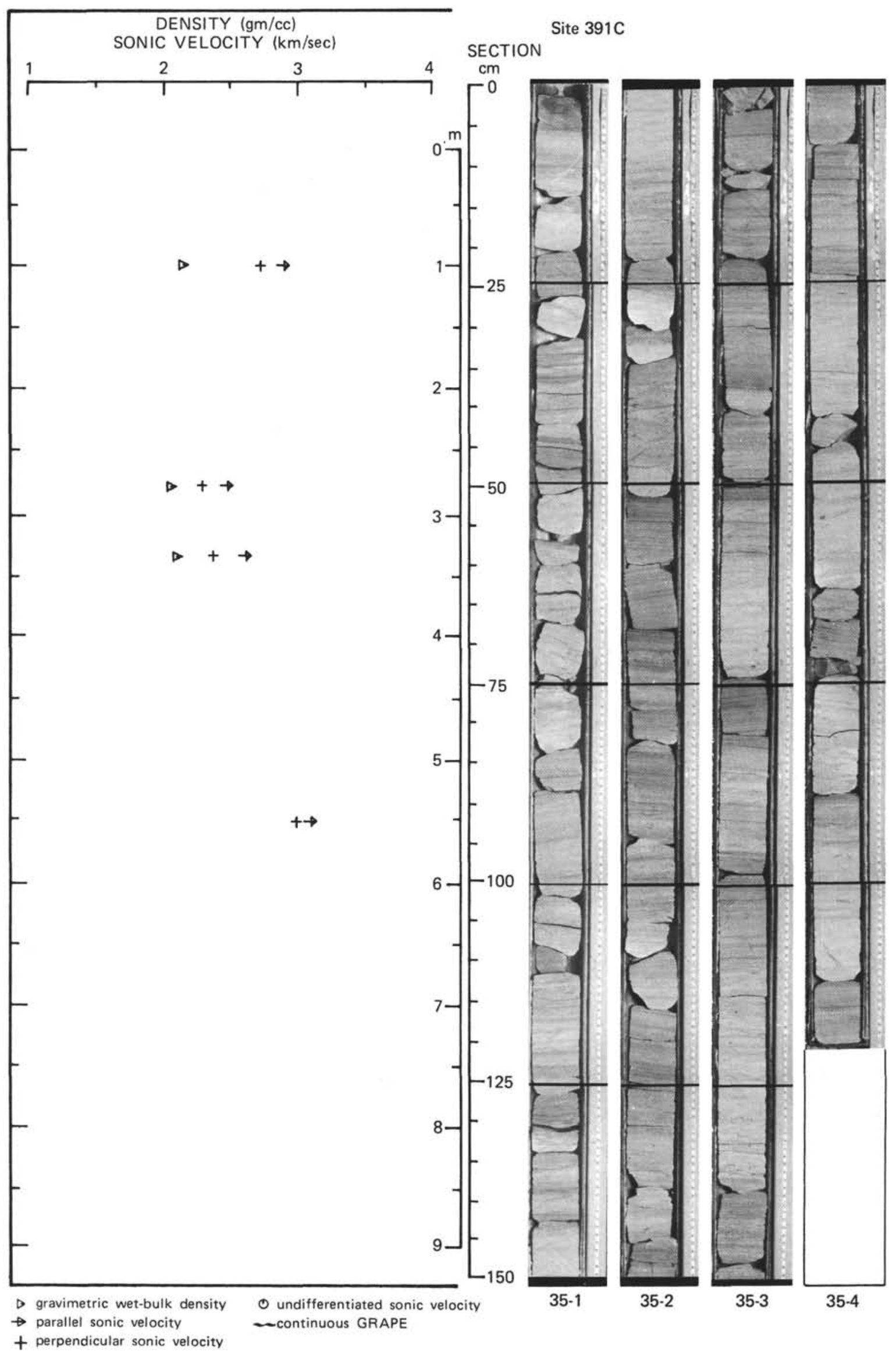




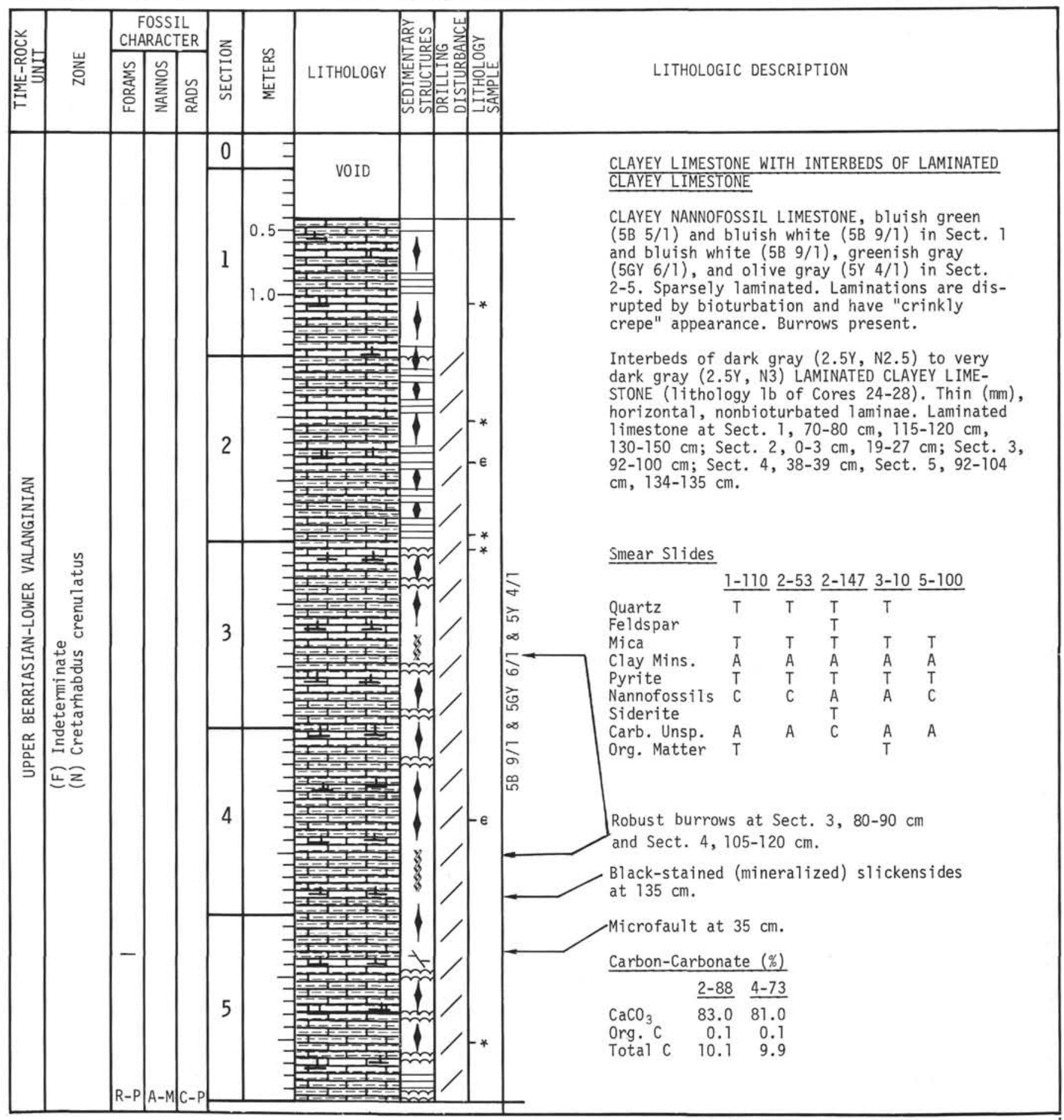


DENSITY $(\mathrm{gm} / \mathrm{cc})$

SONIC VELOCITY $(\mathrm{km} / \mathrm{sec})$
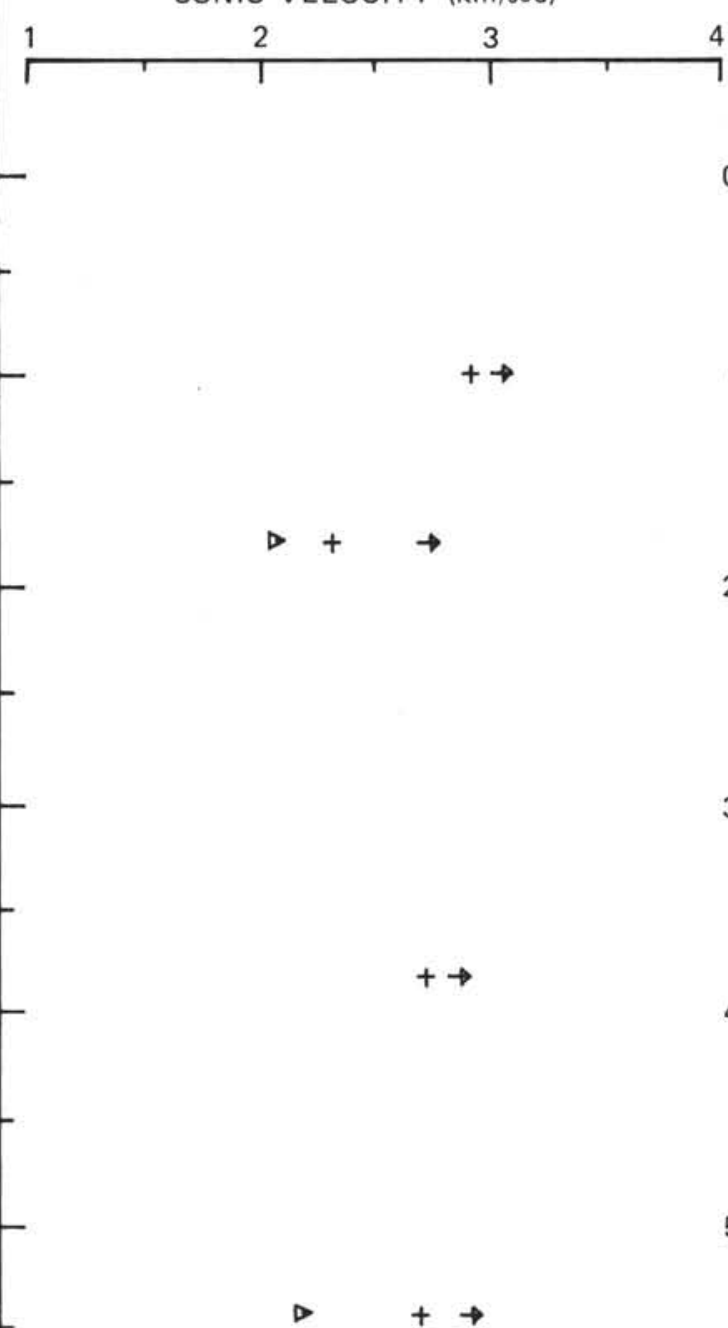

$D+\rightarrow$

D gravimetric wet-bulk density

$\rightarrow$ parallel sonic velocity

○ undifferentiated sonic velocity

+ perpendicular sonic velocity

Site 391C SECTION

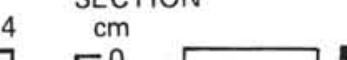

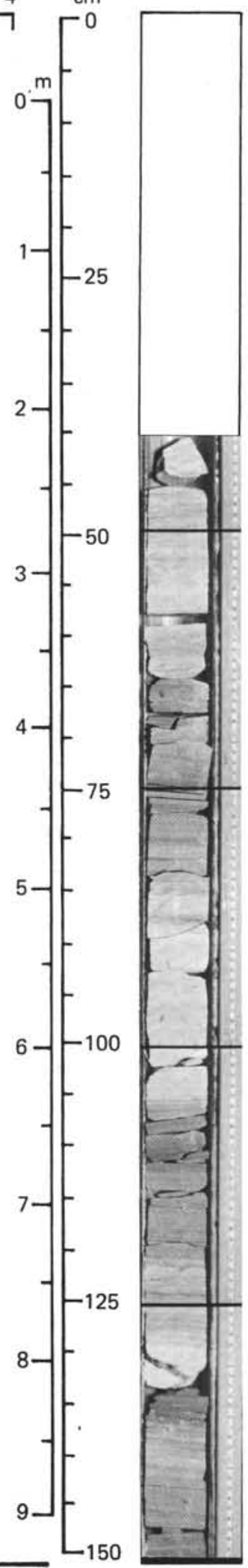

$36-1$
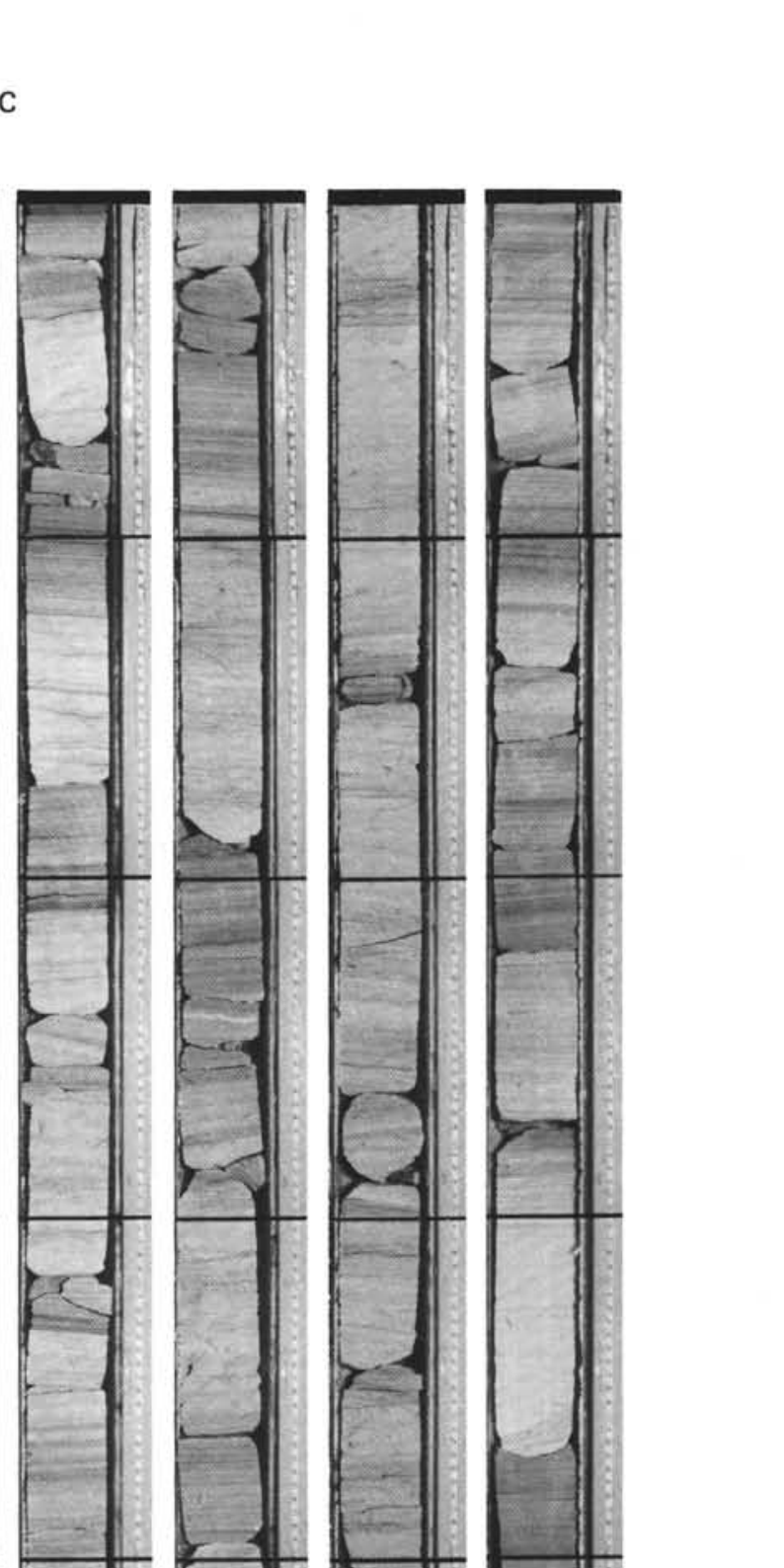

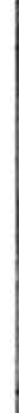
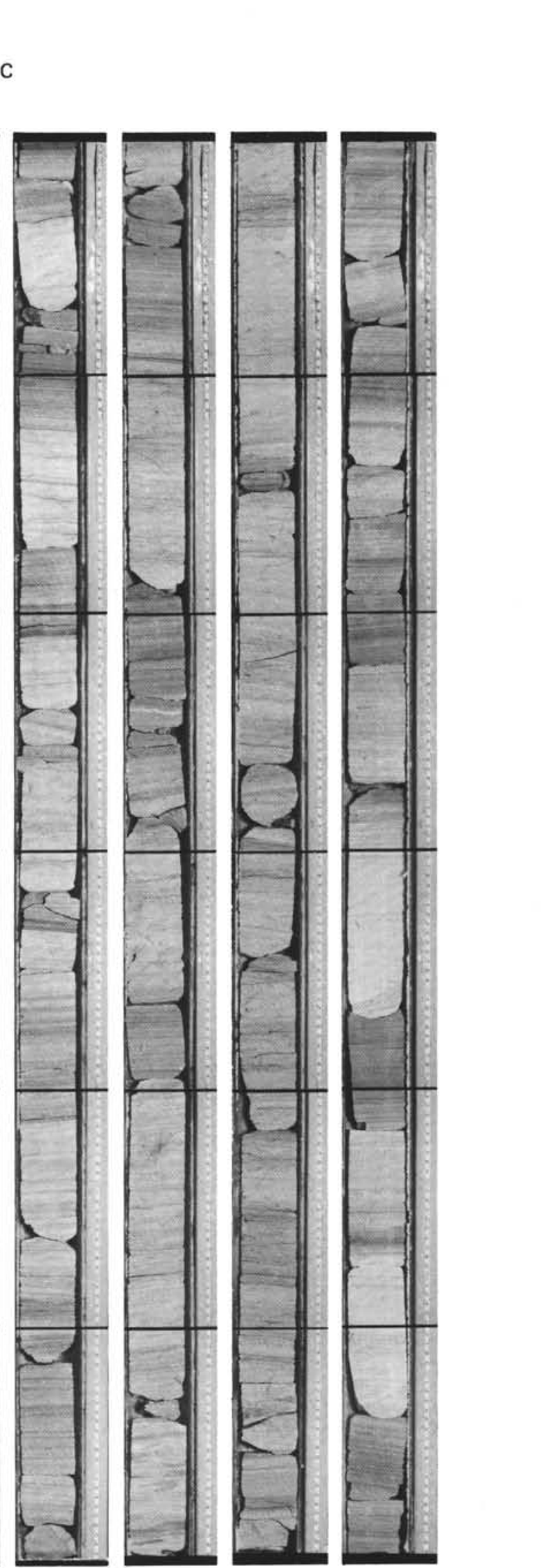

$36-2 \quad 36-3$

36-5 


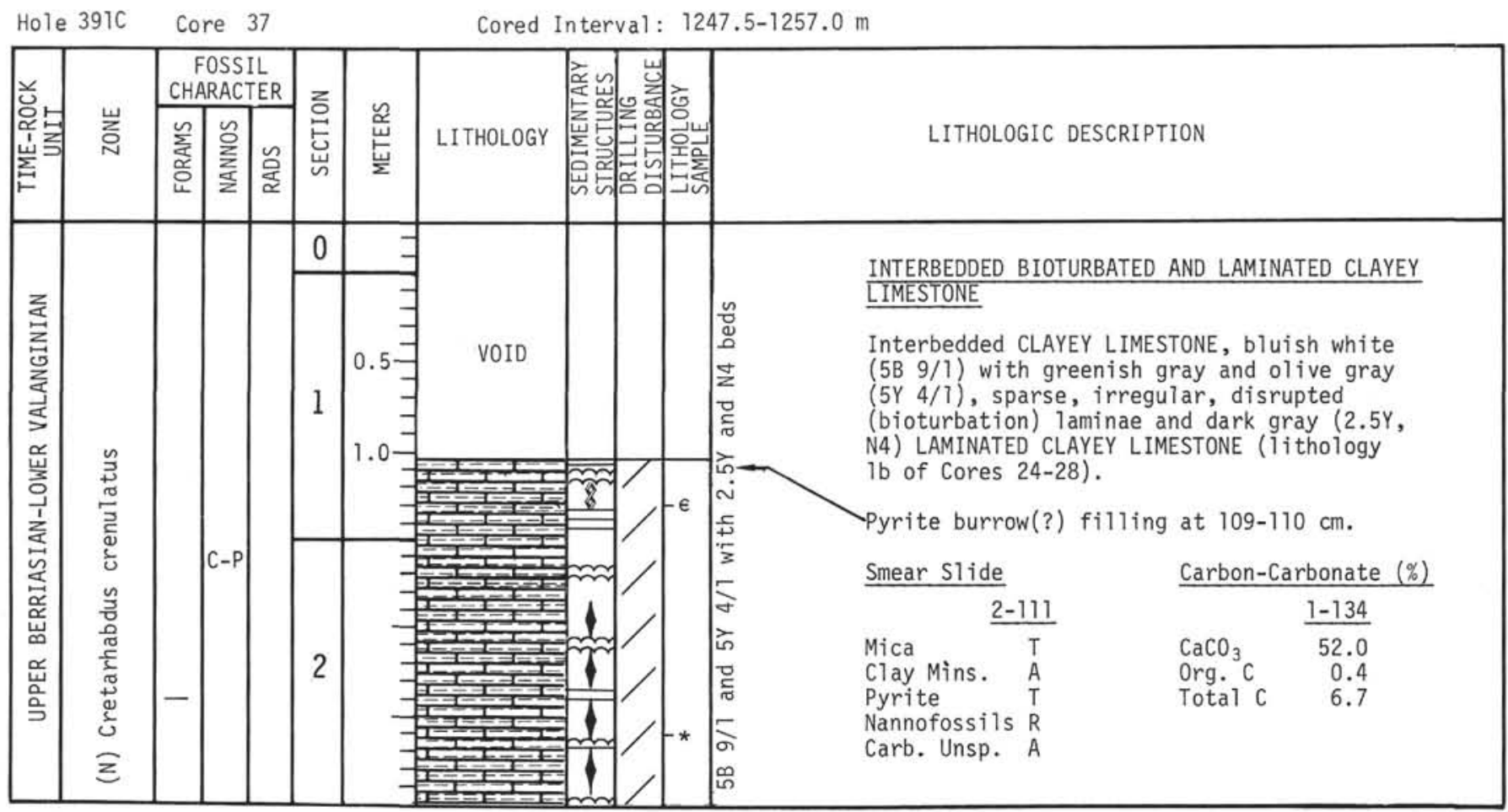




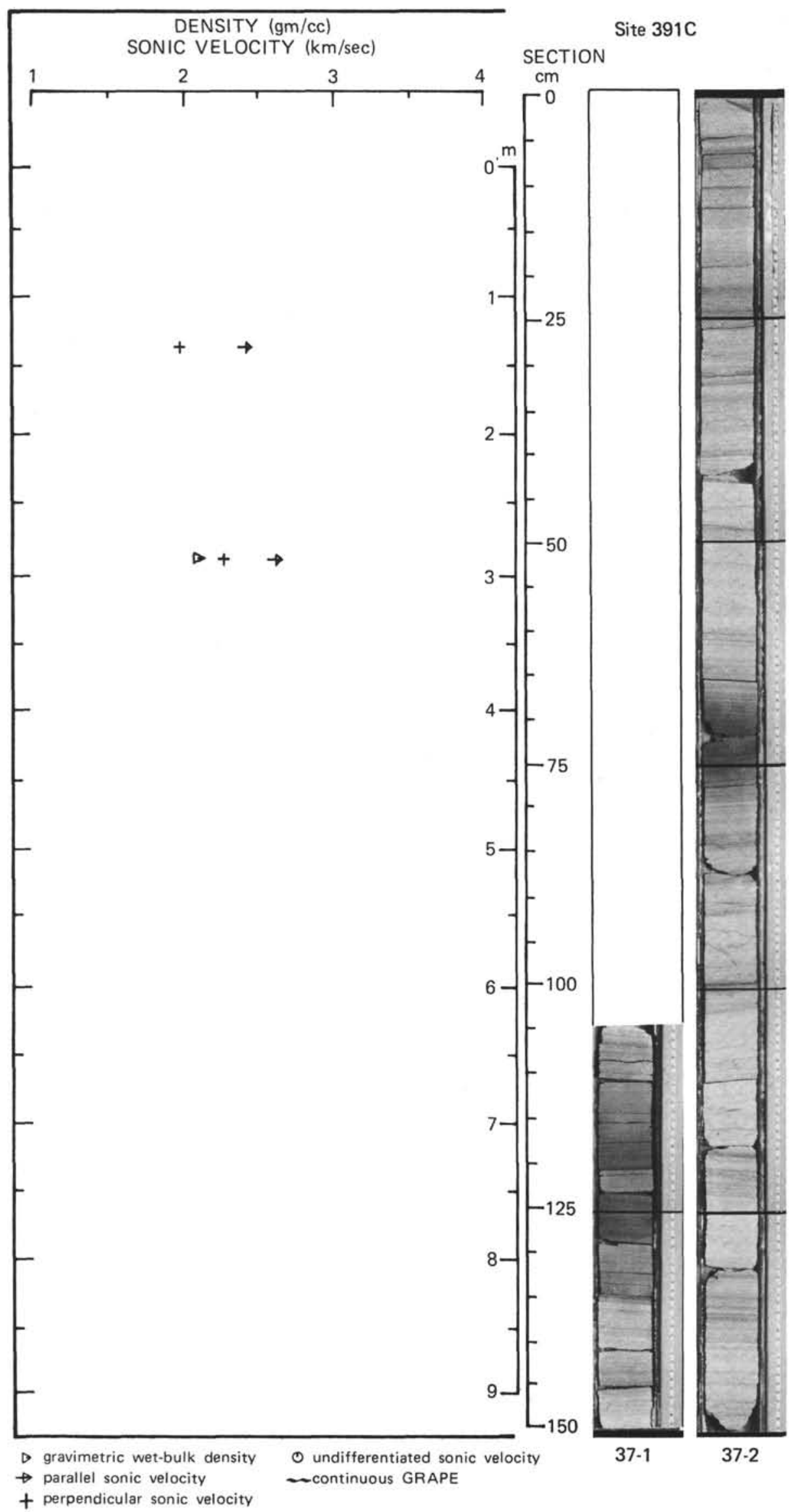




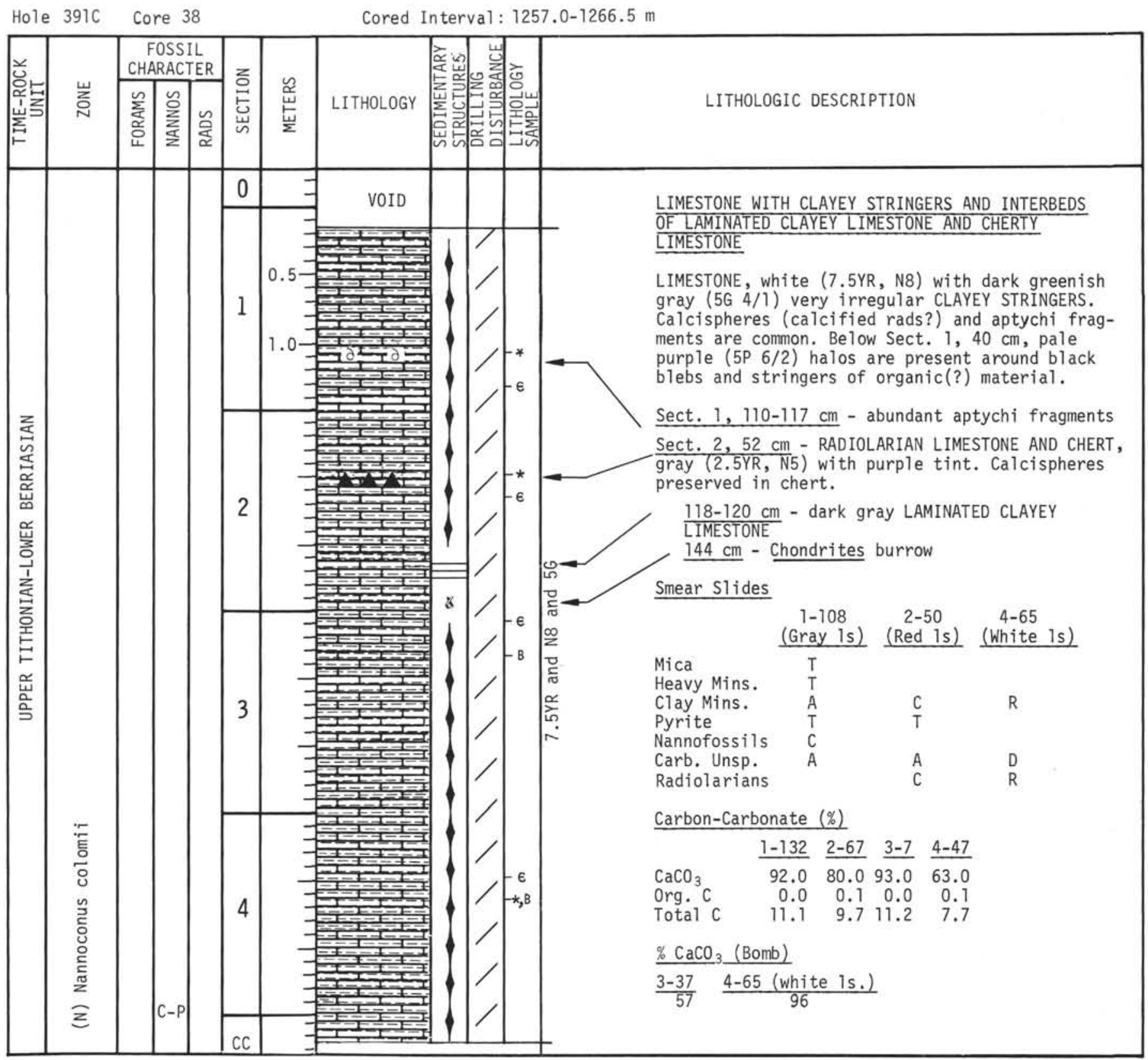




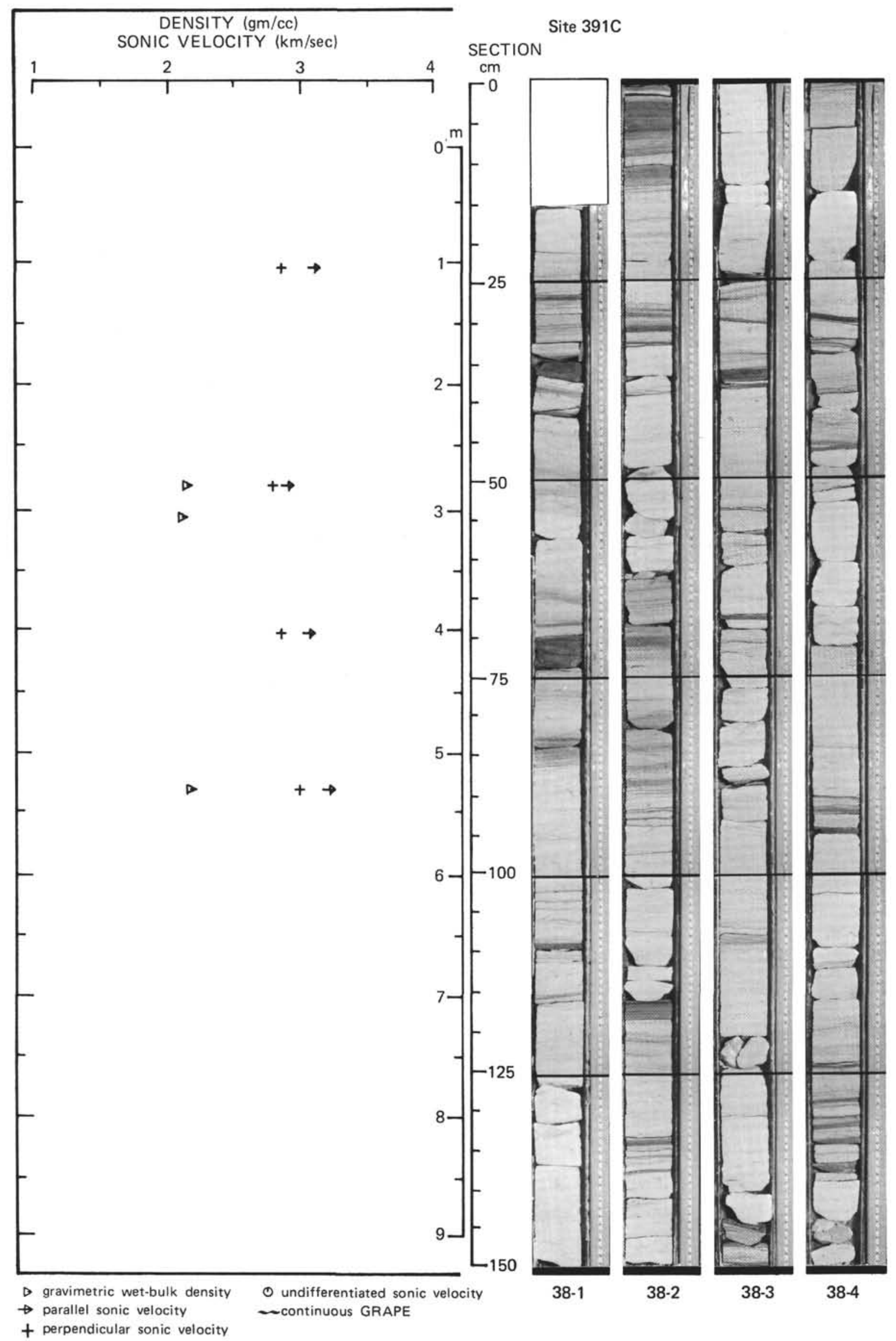




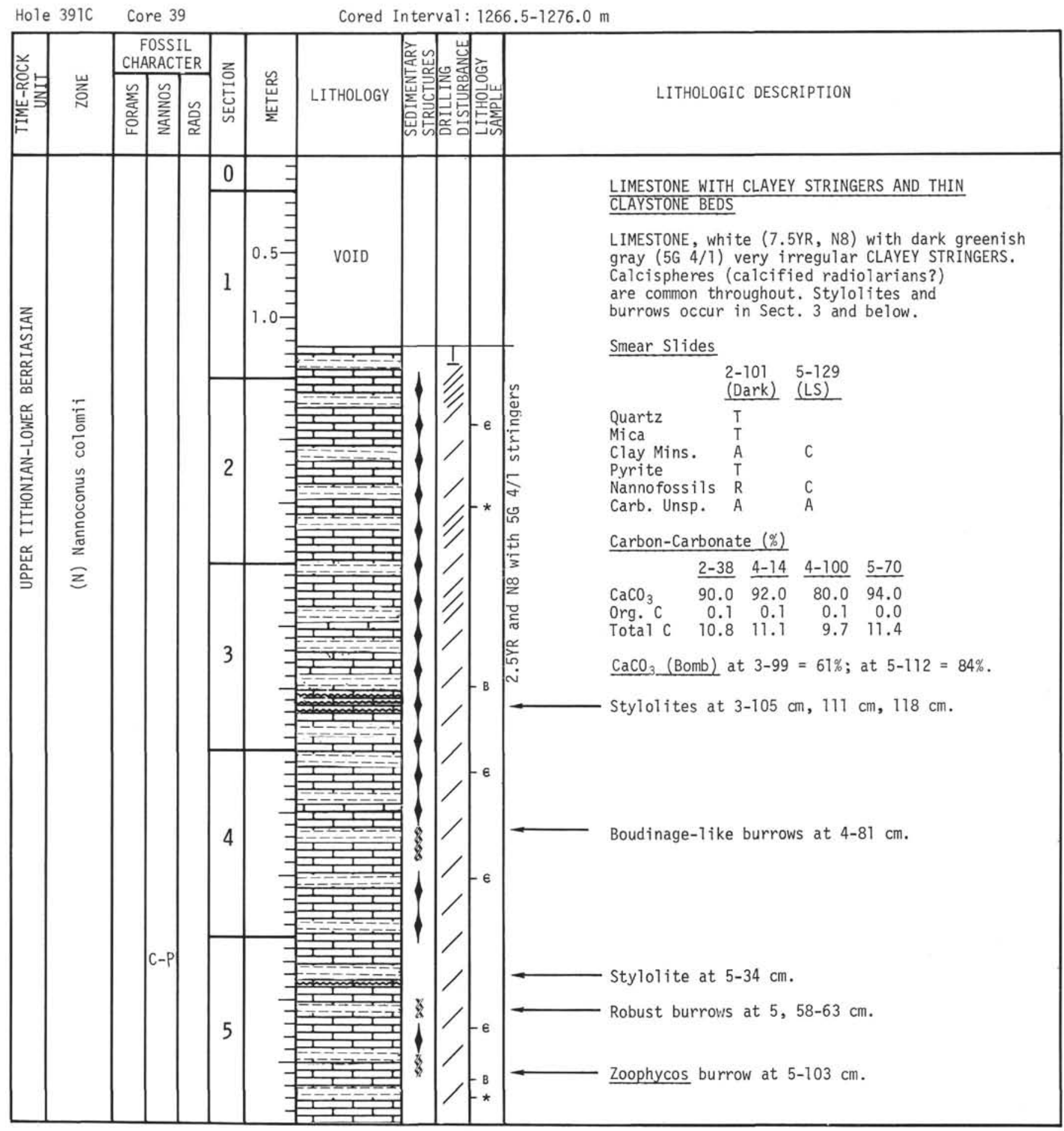




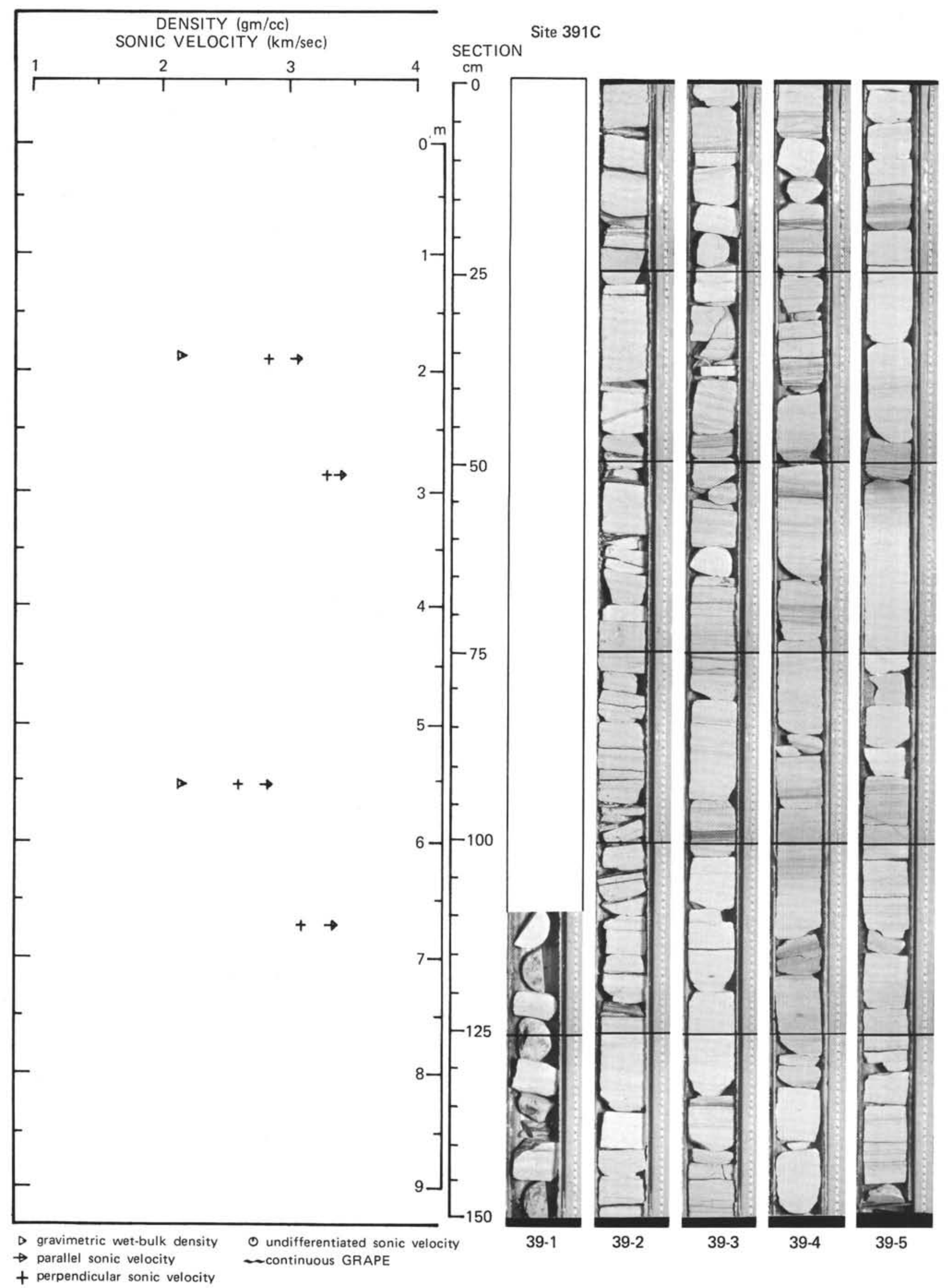


Hole $391 \mathrm{C}$ Core 40

Cored Interval: 1276.0-1285.5 m

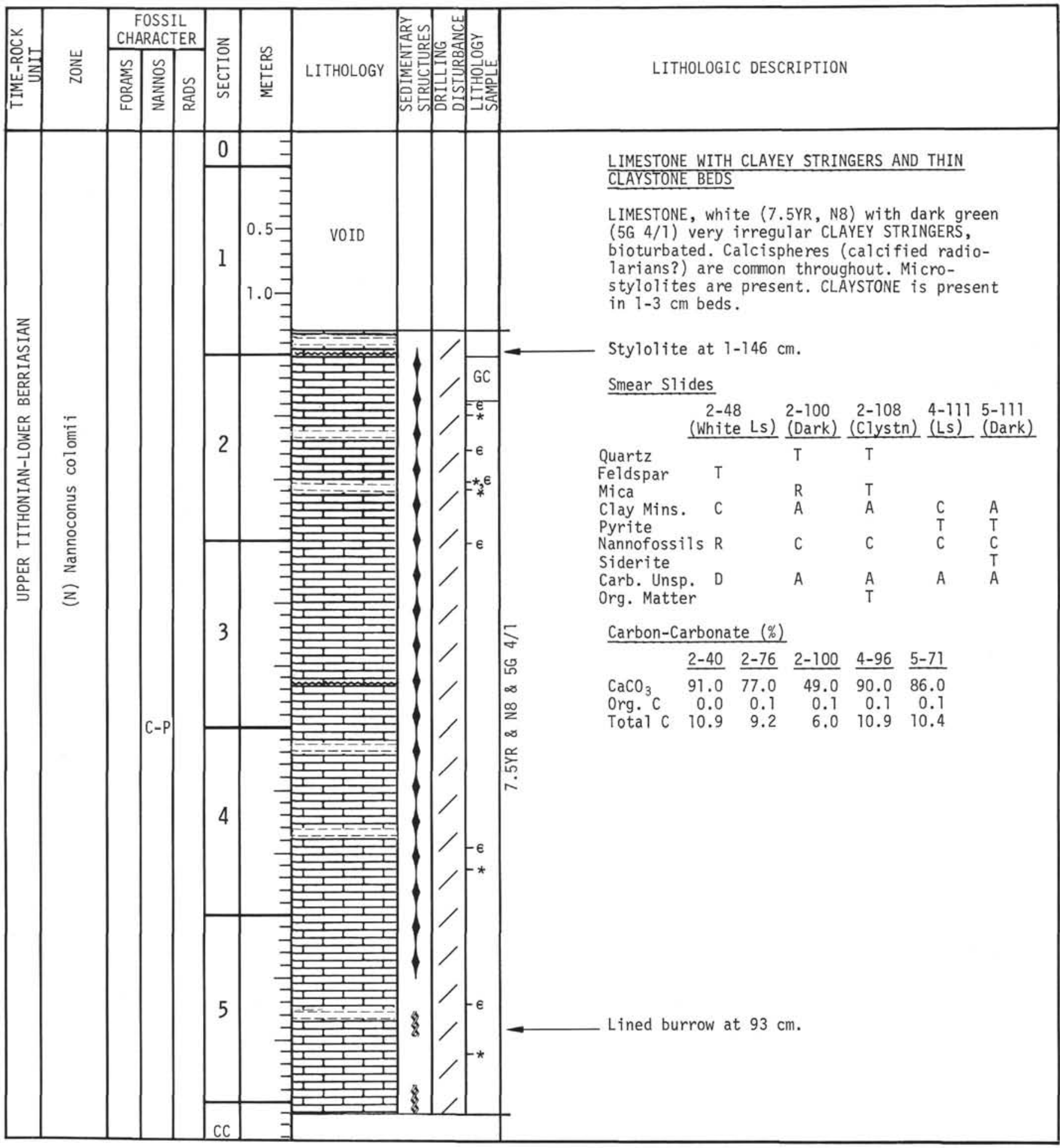


Hole 391C Core $41 \quad$ Cored Interval: 1285.5-1295.0 m

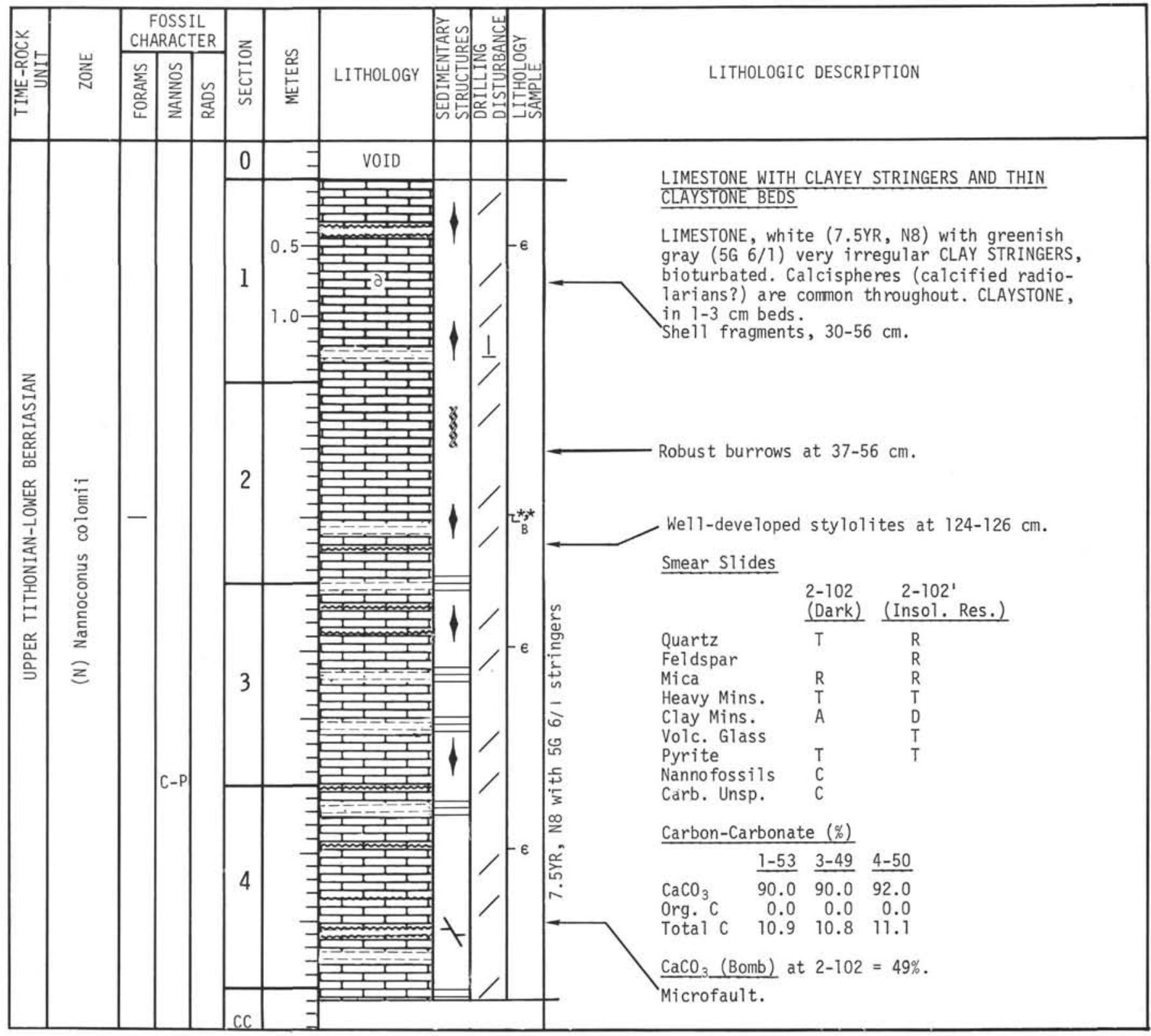




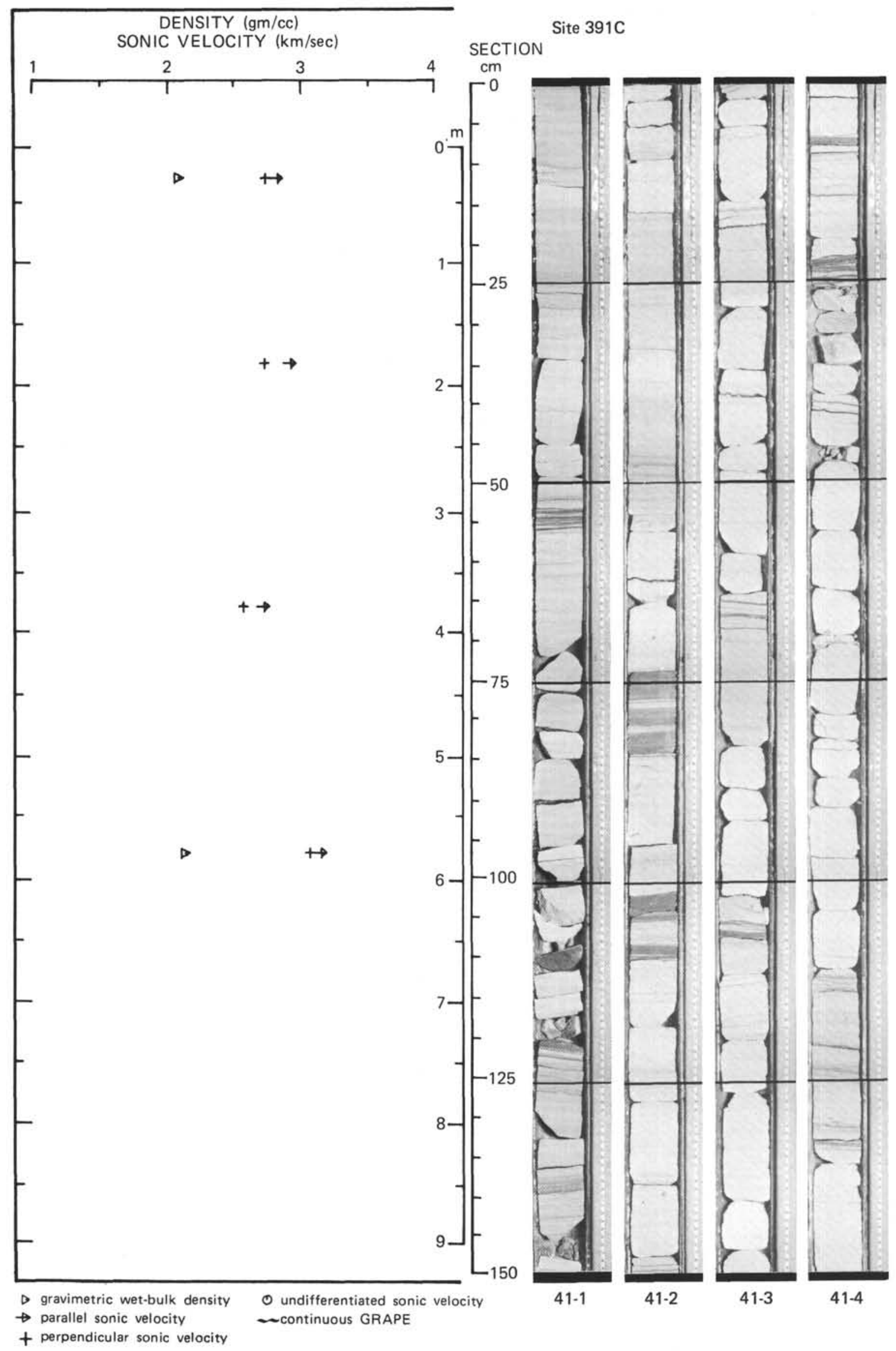




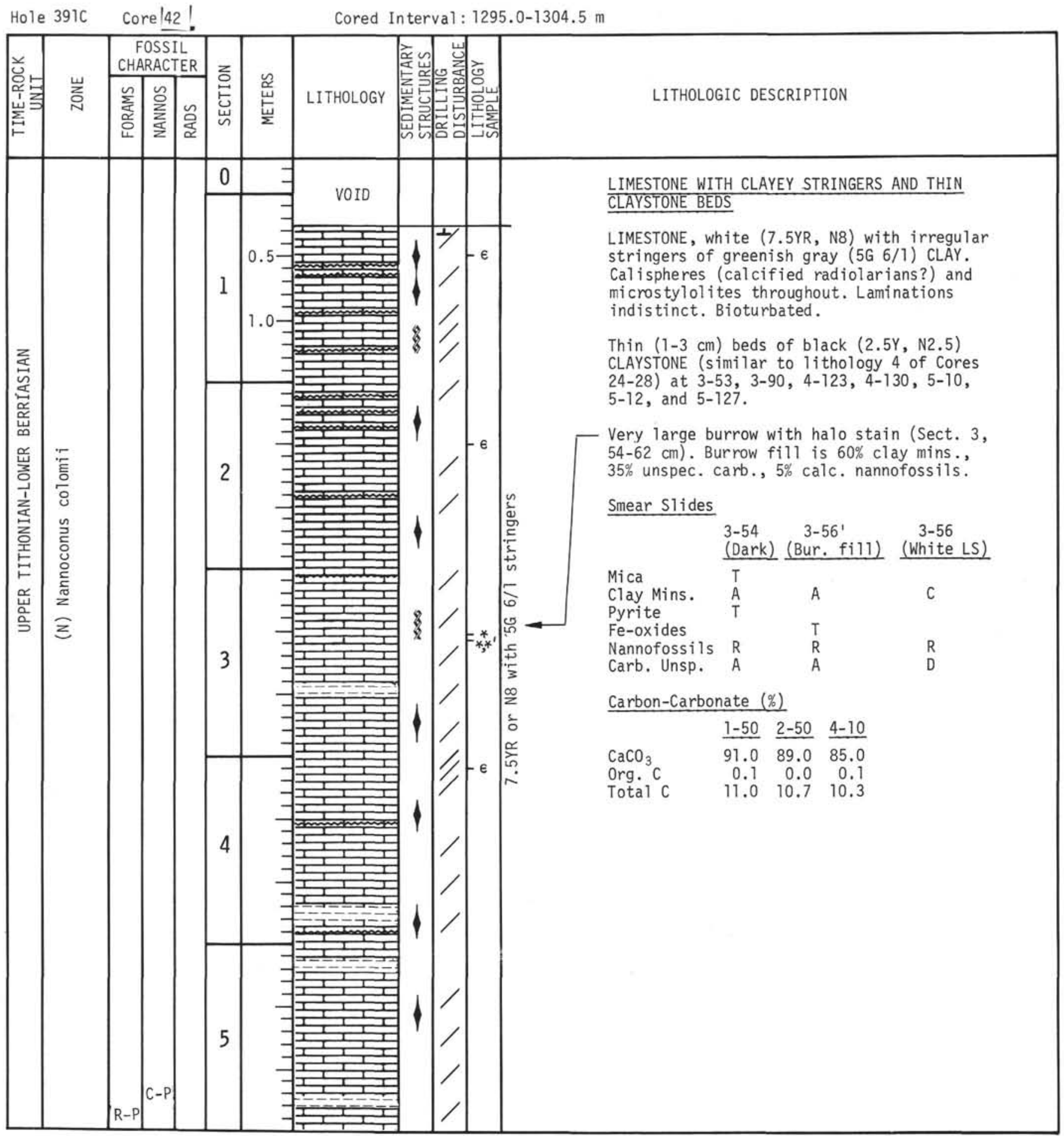




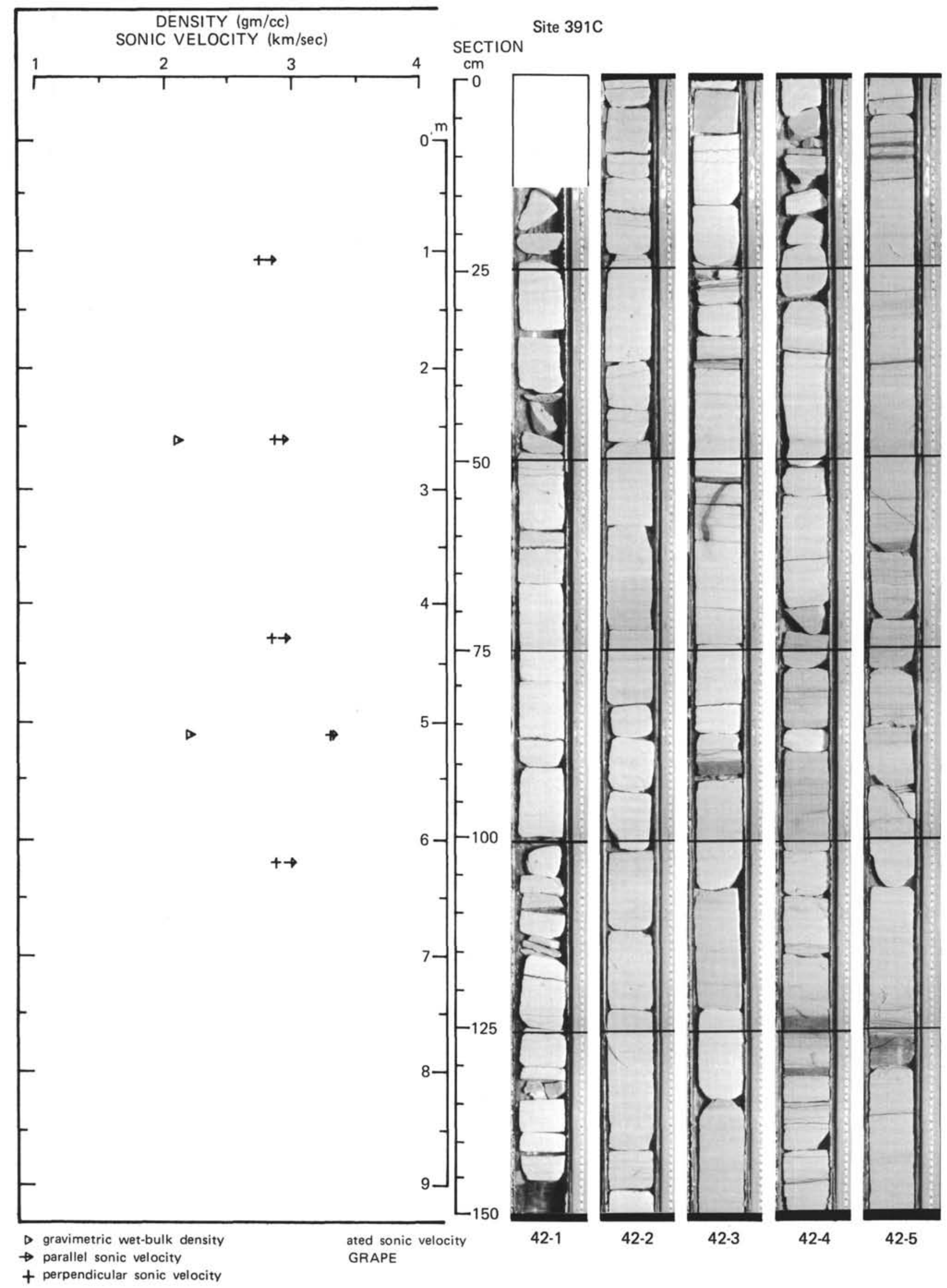




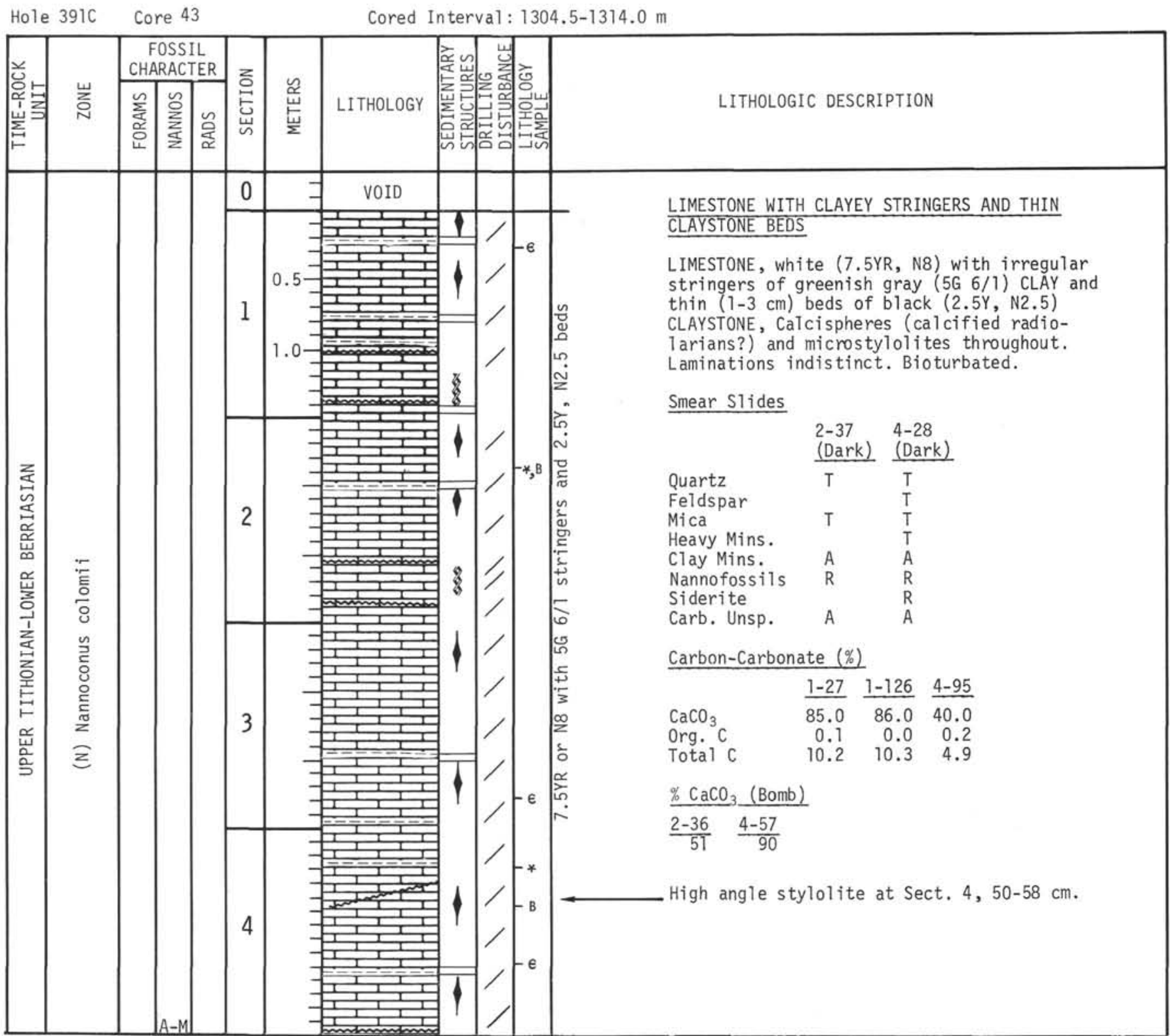




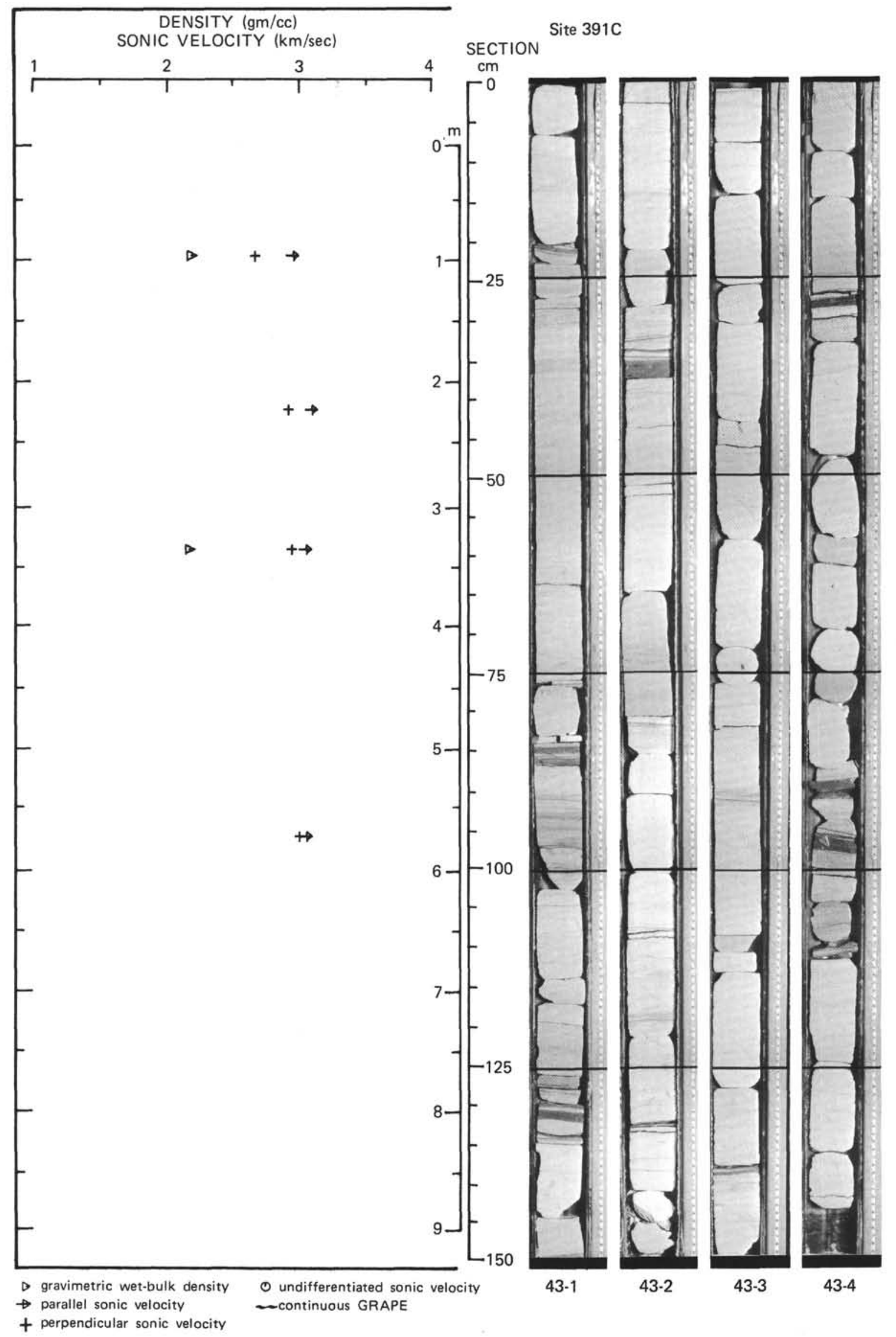




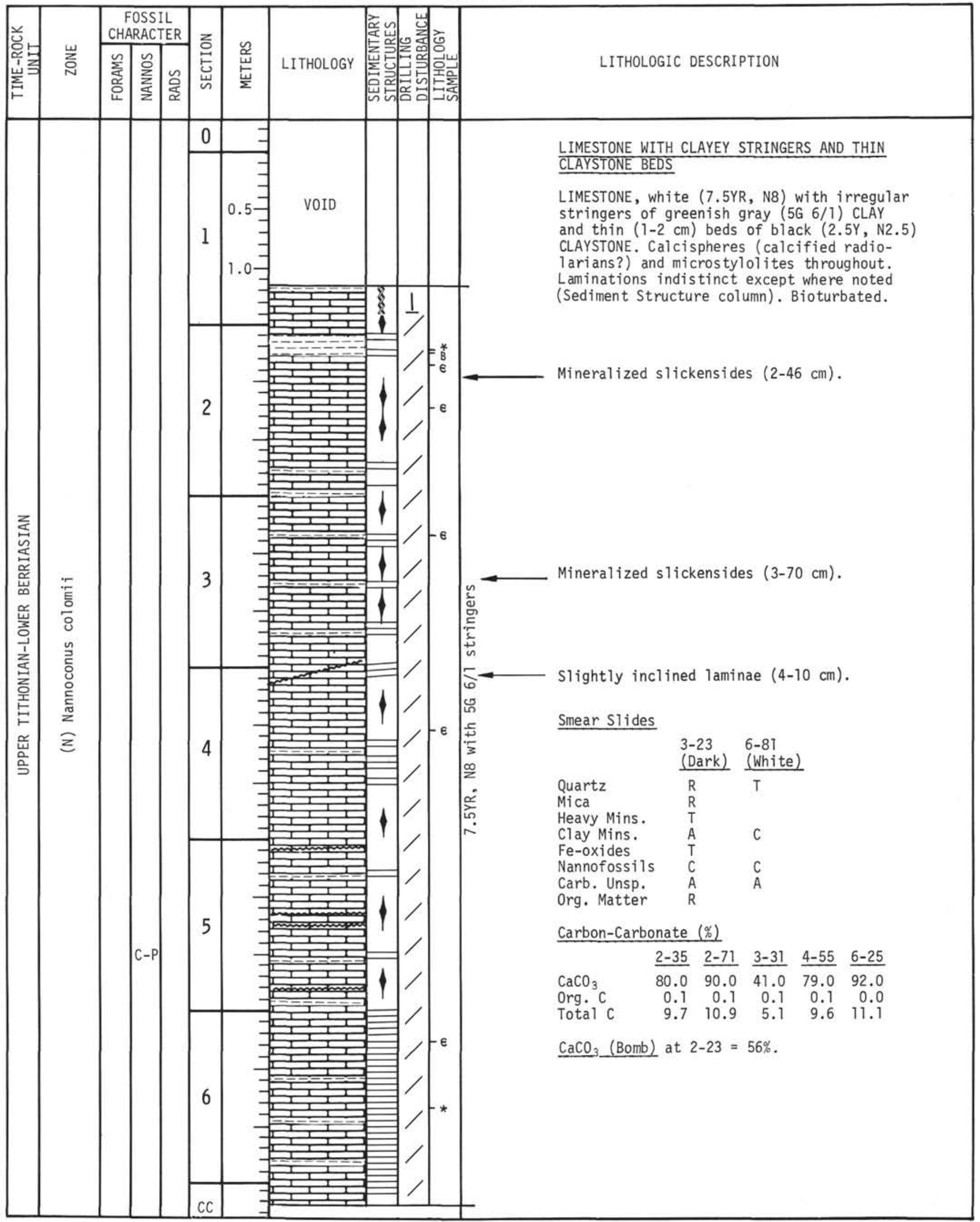




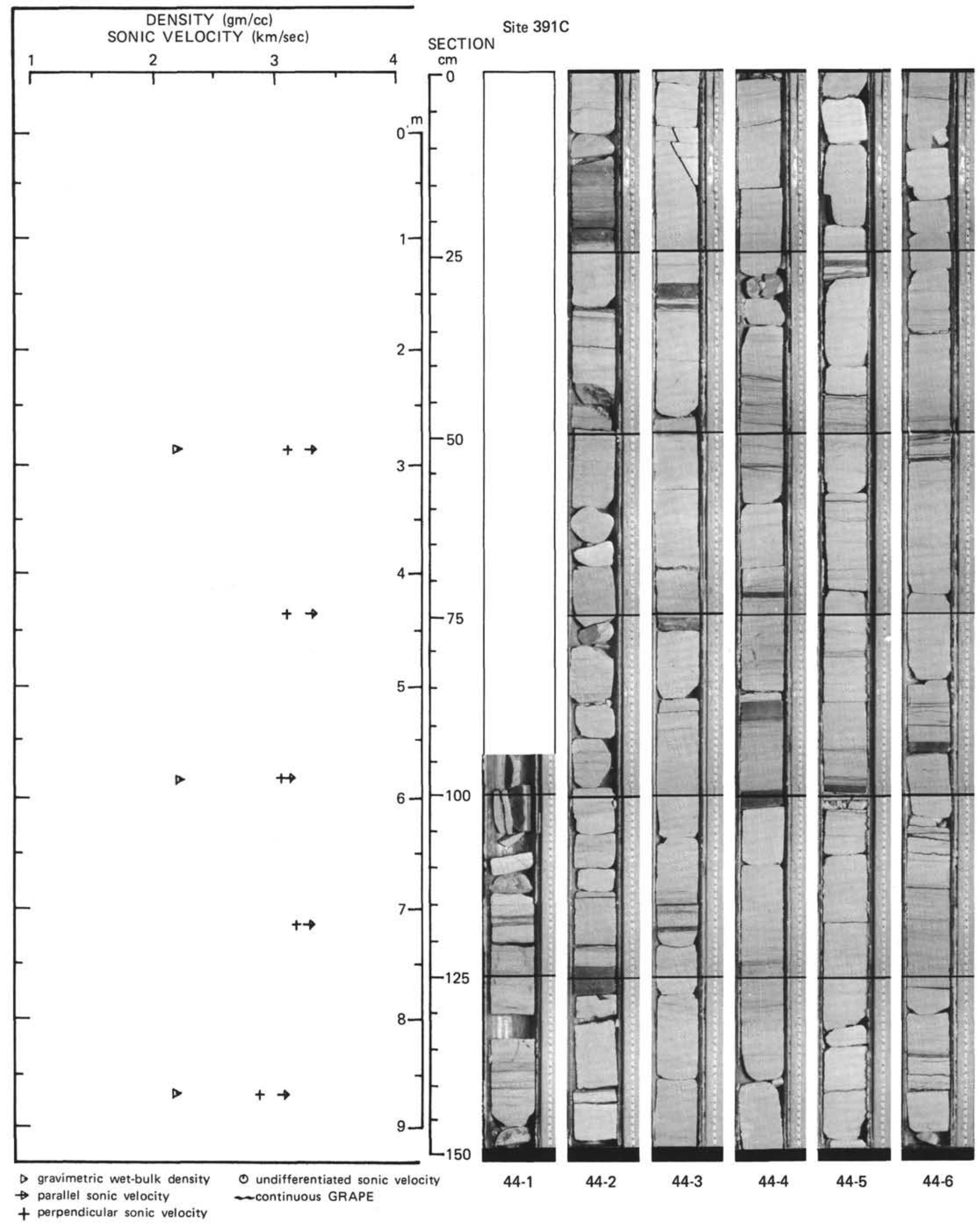




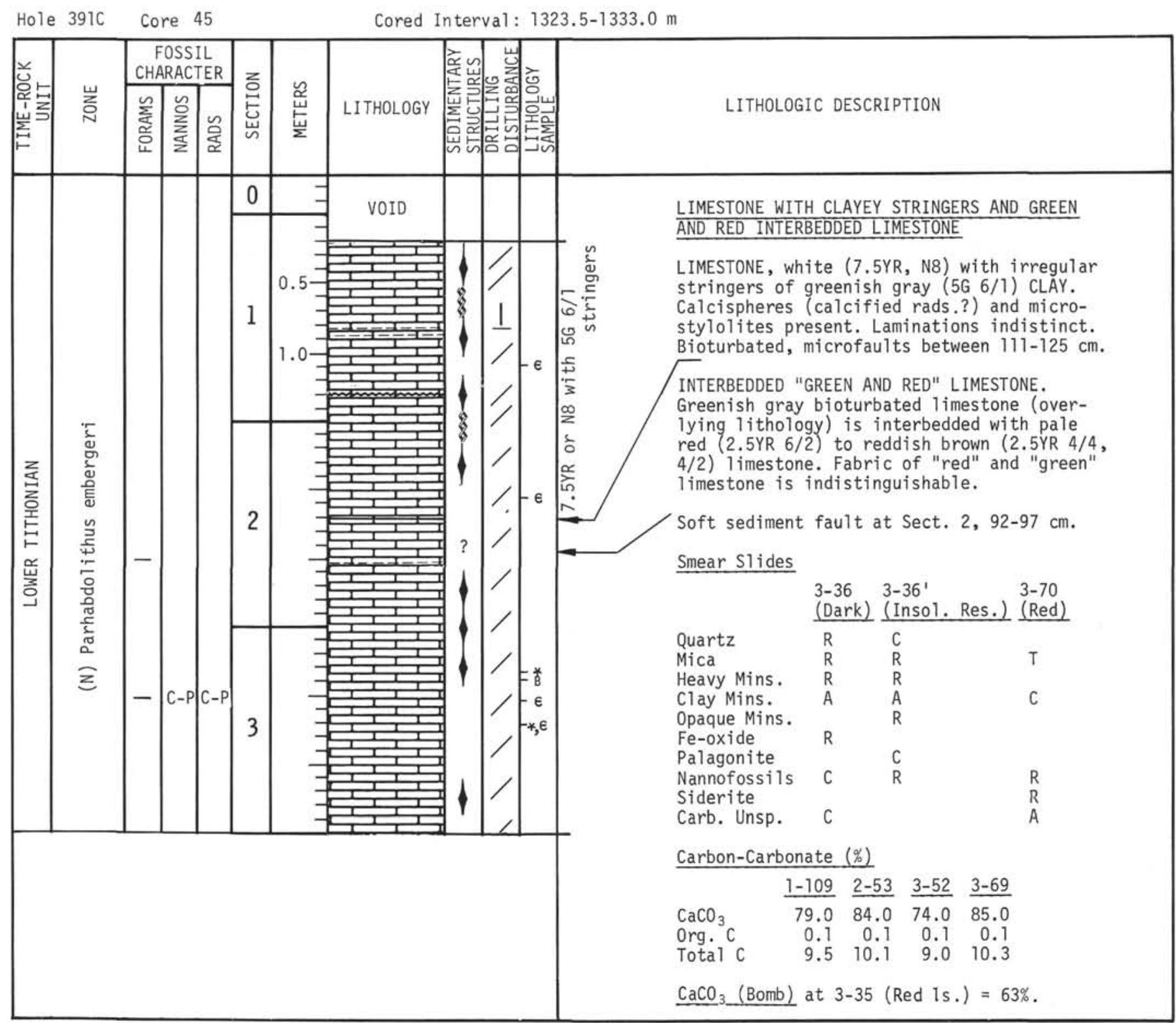




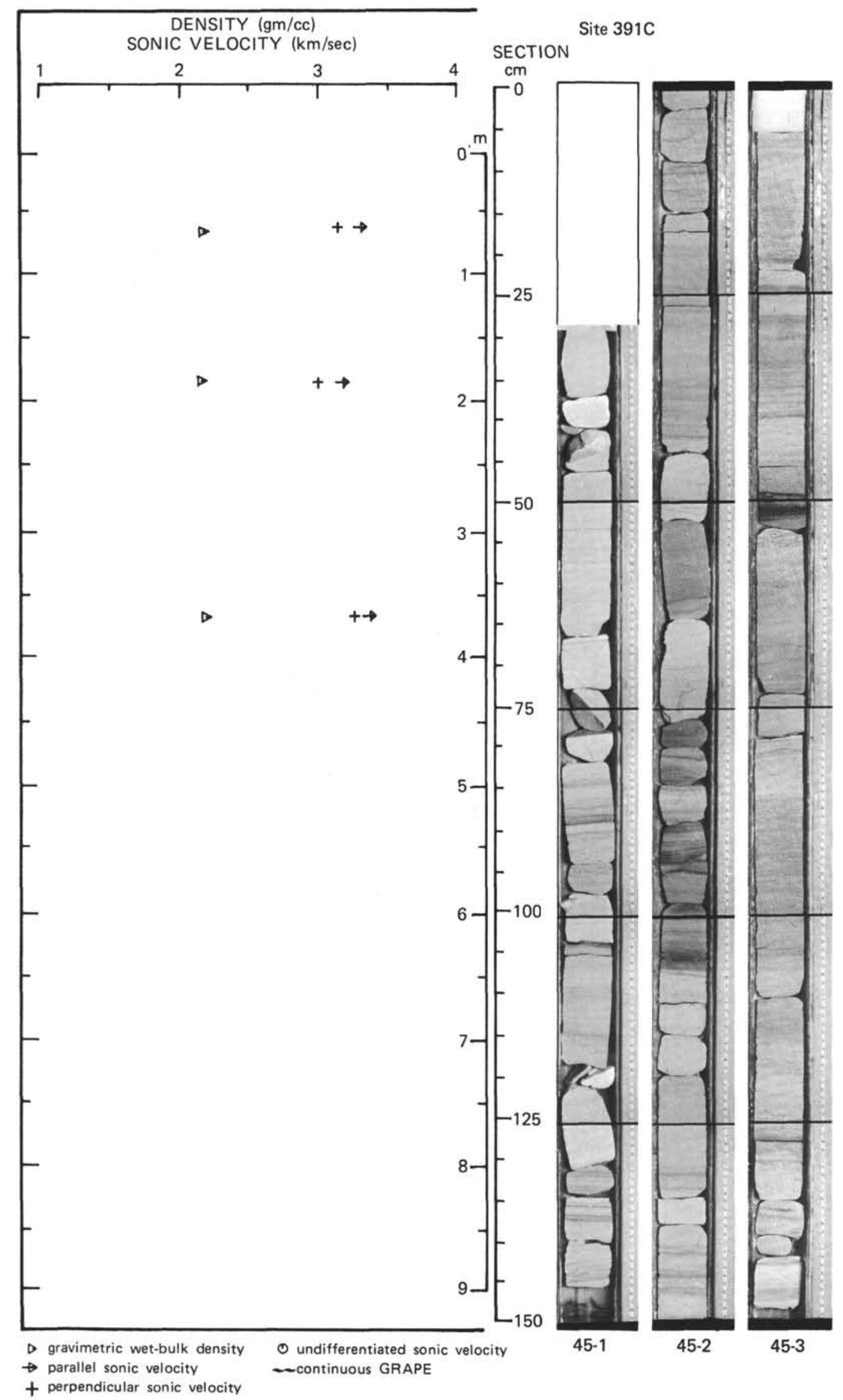




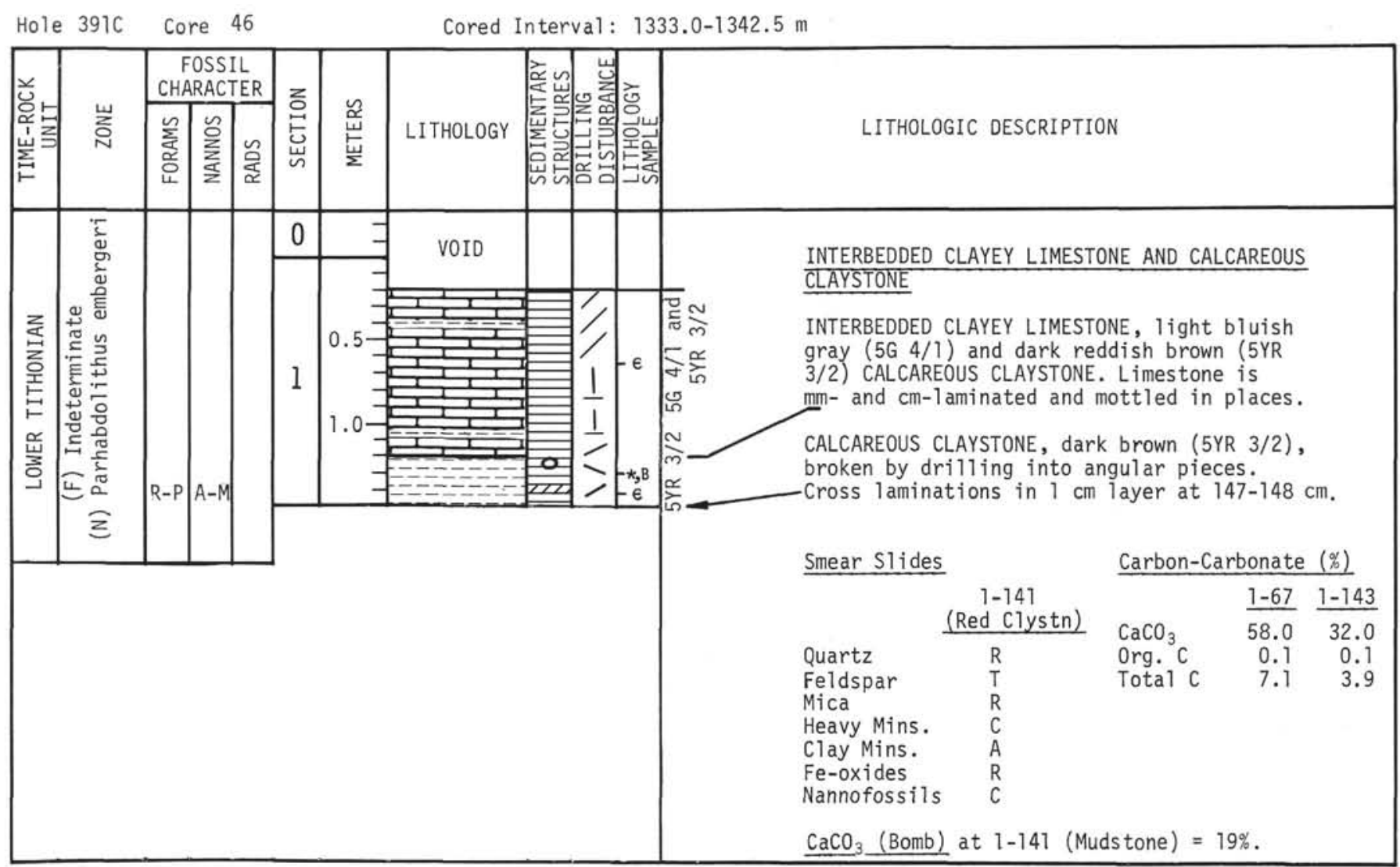




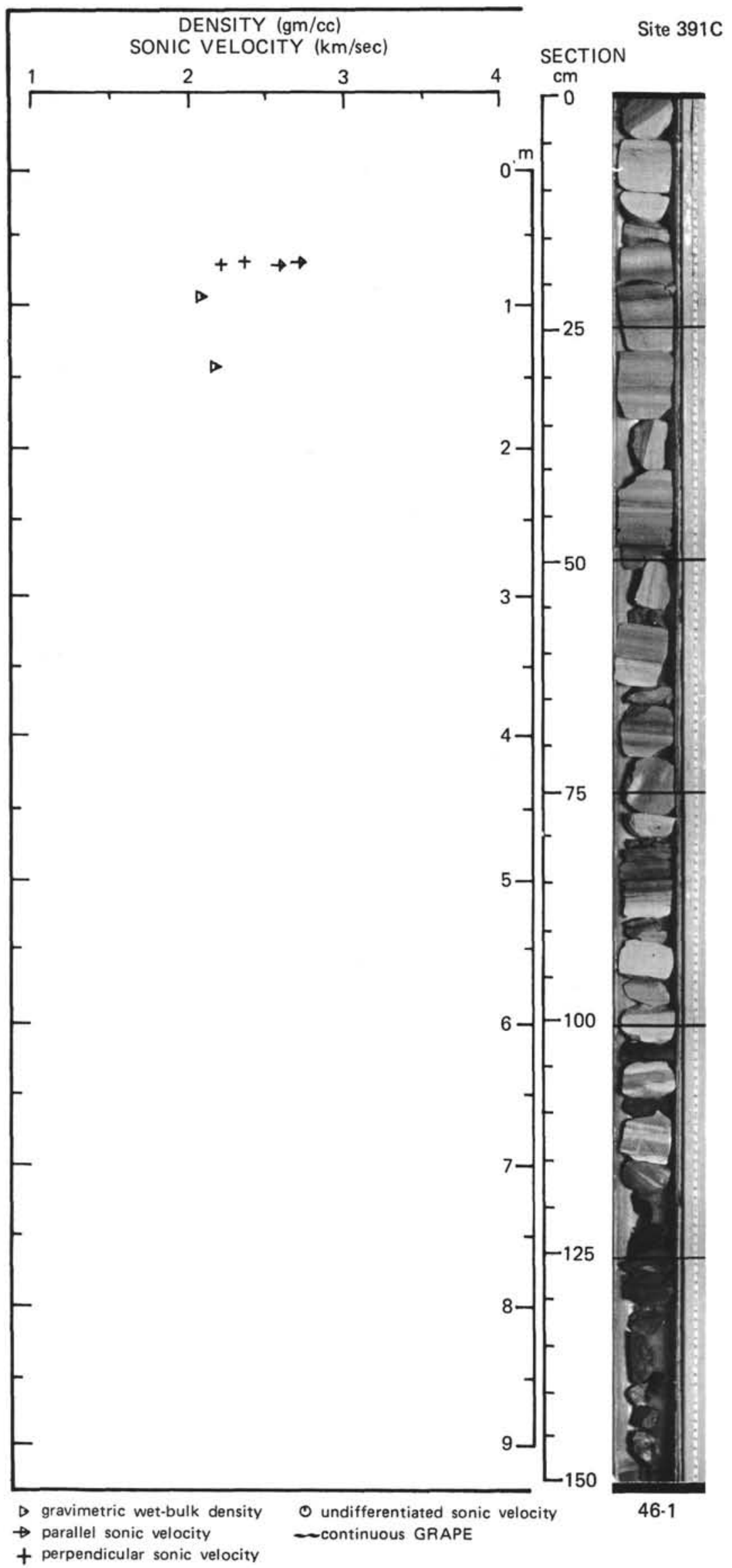




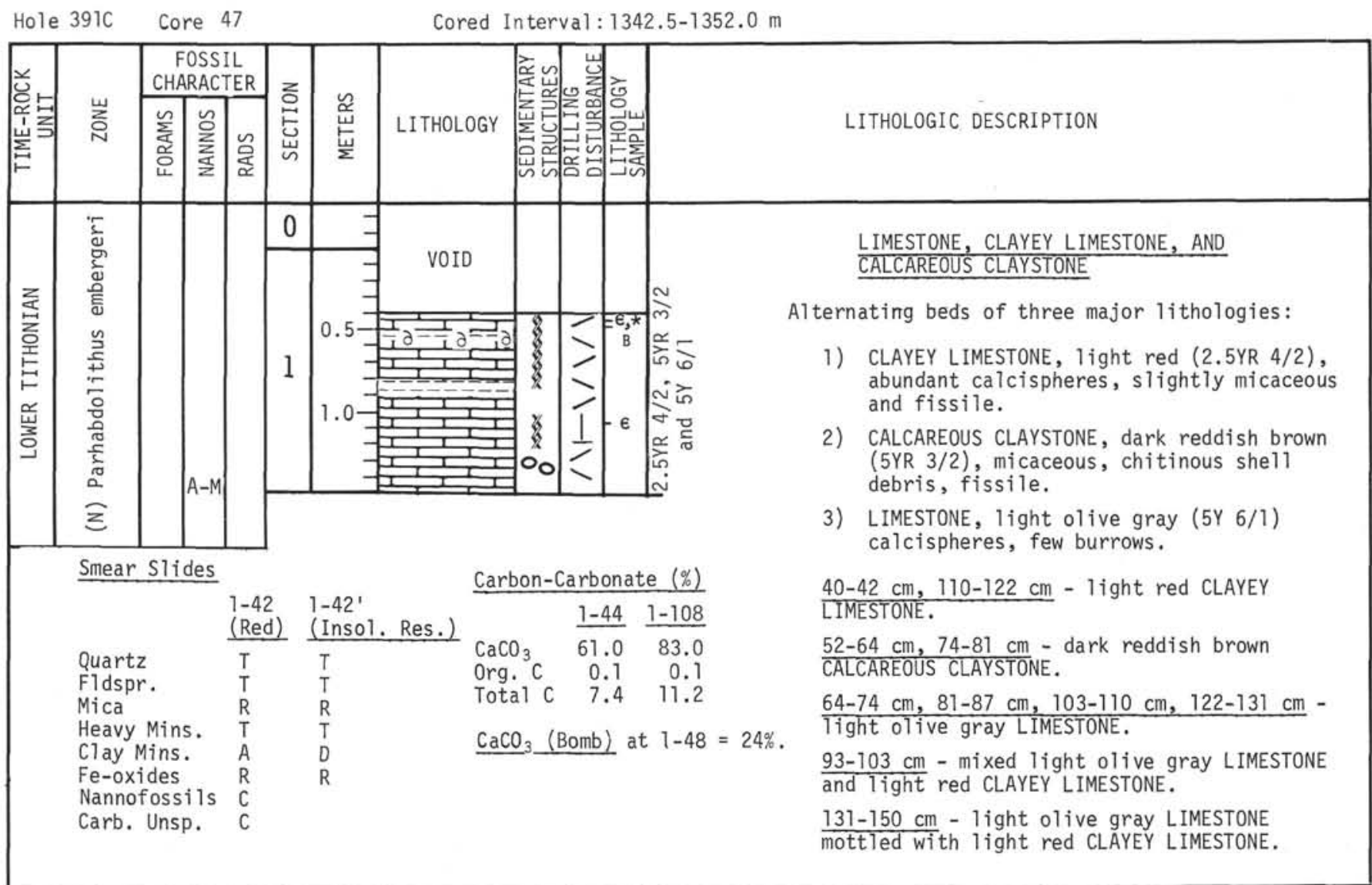

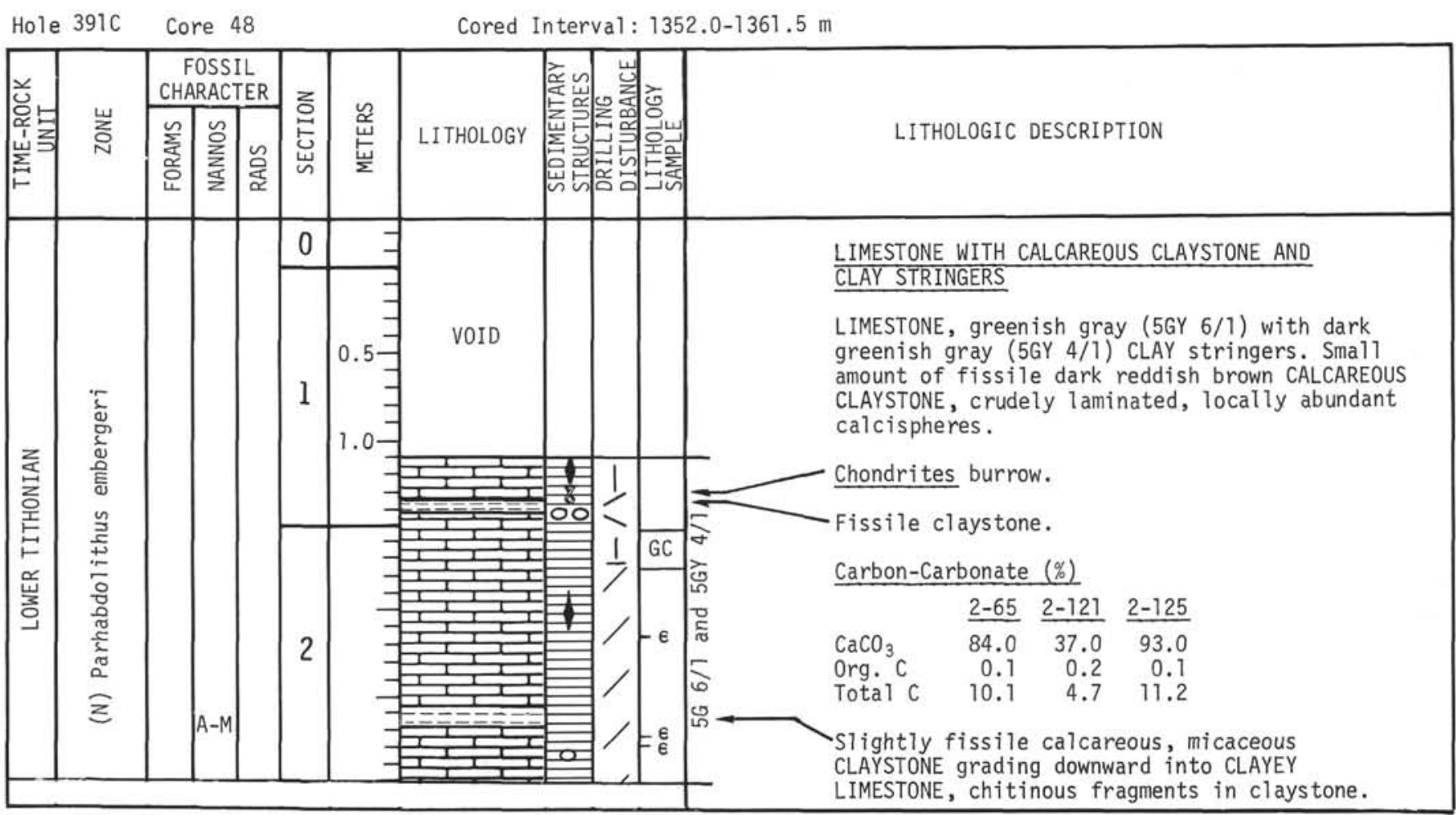




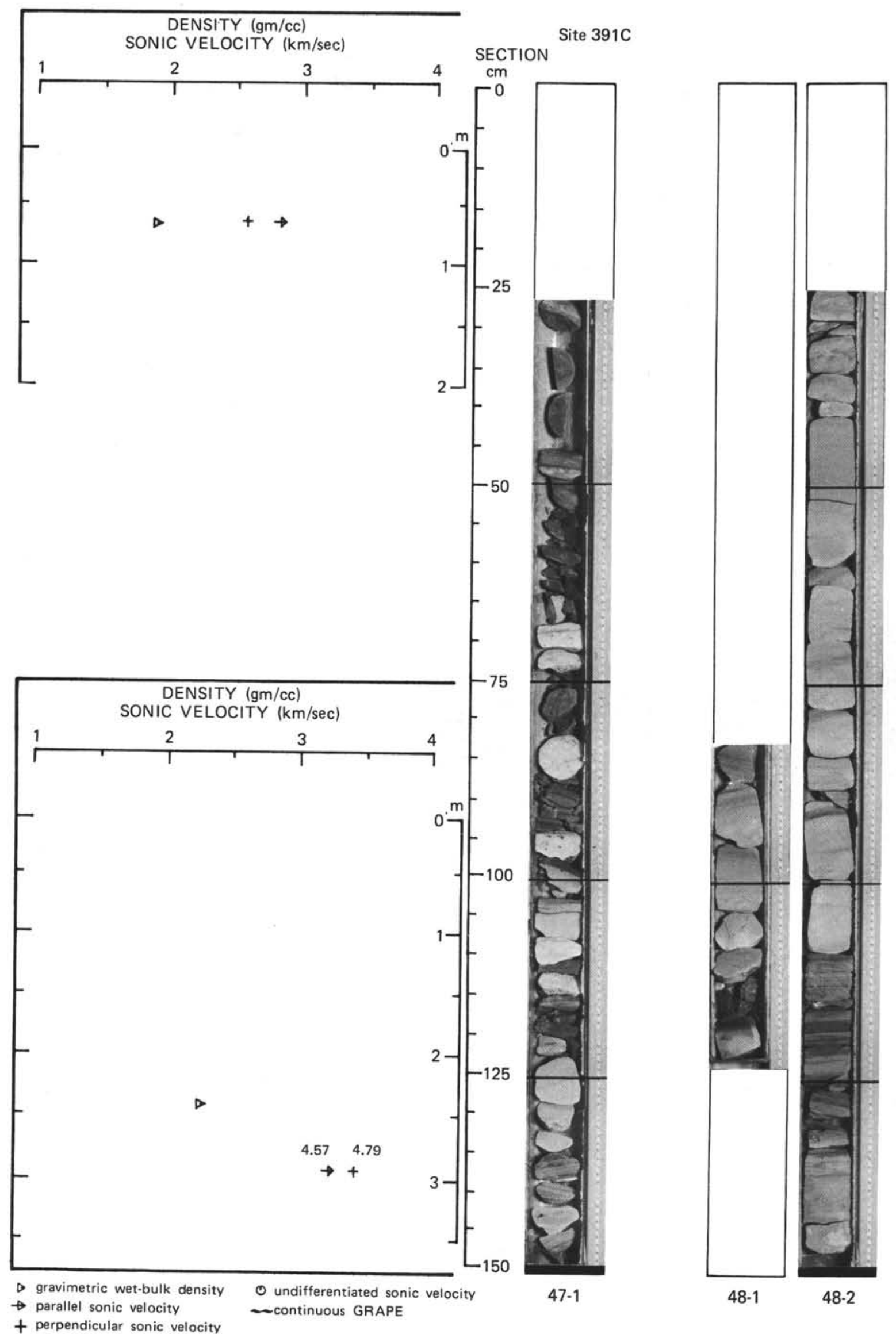




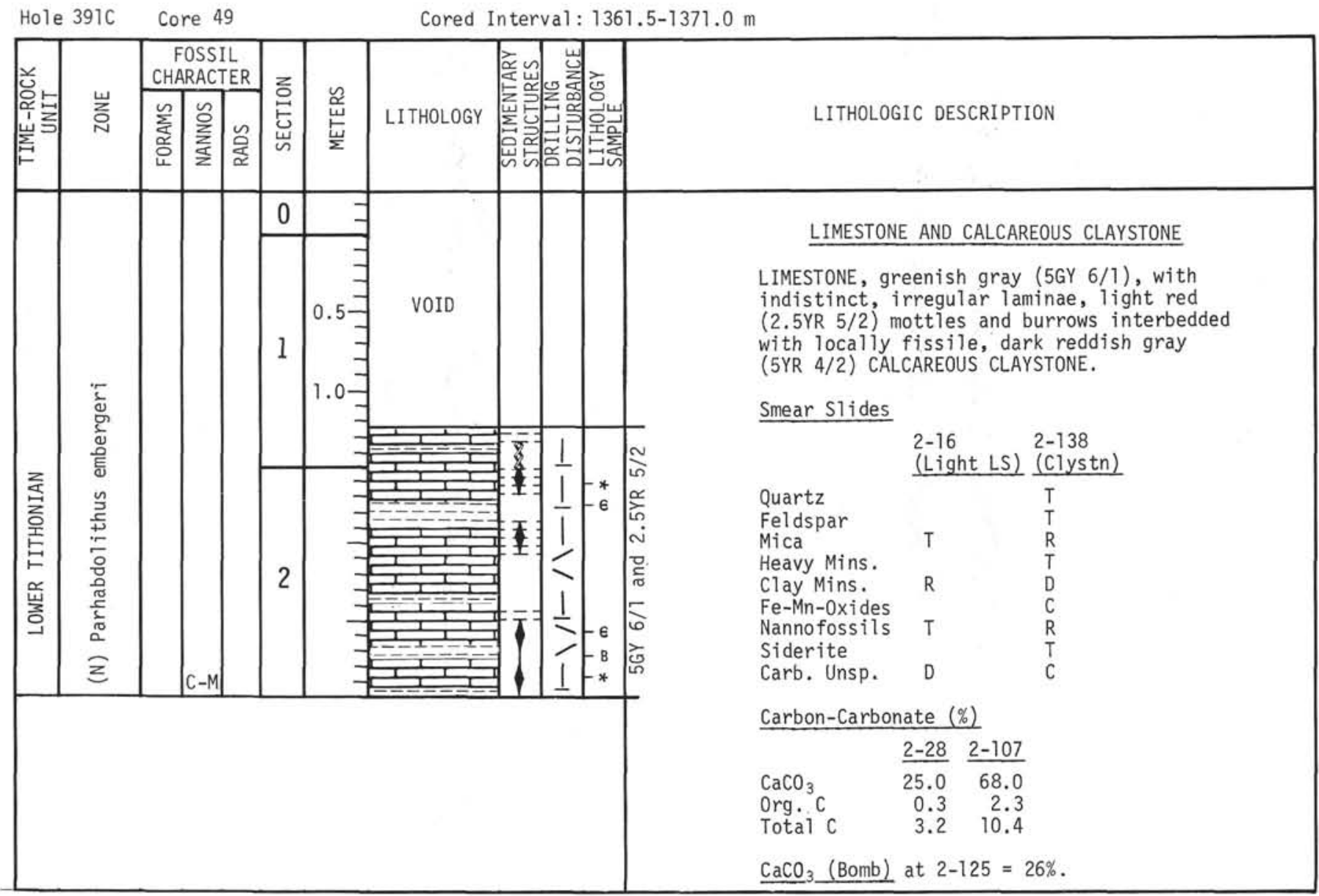

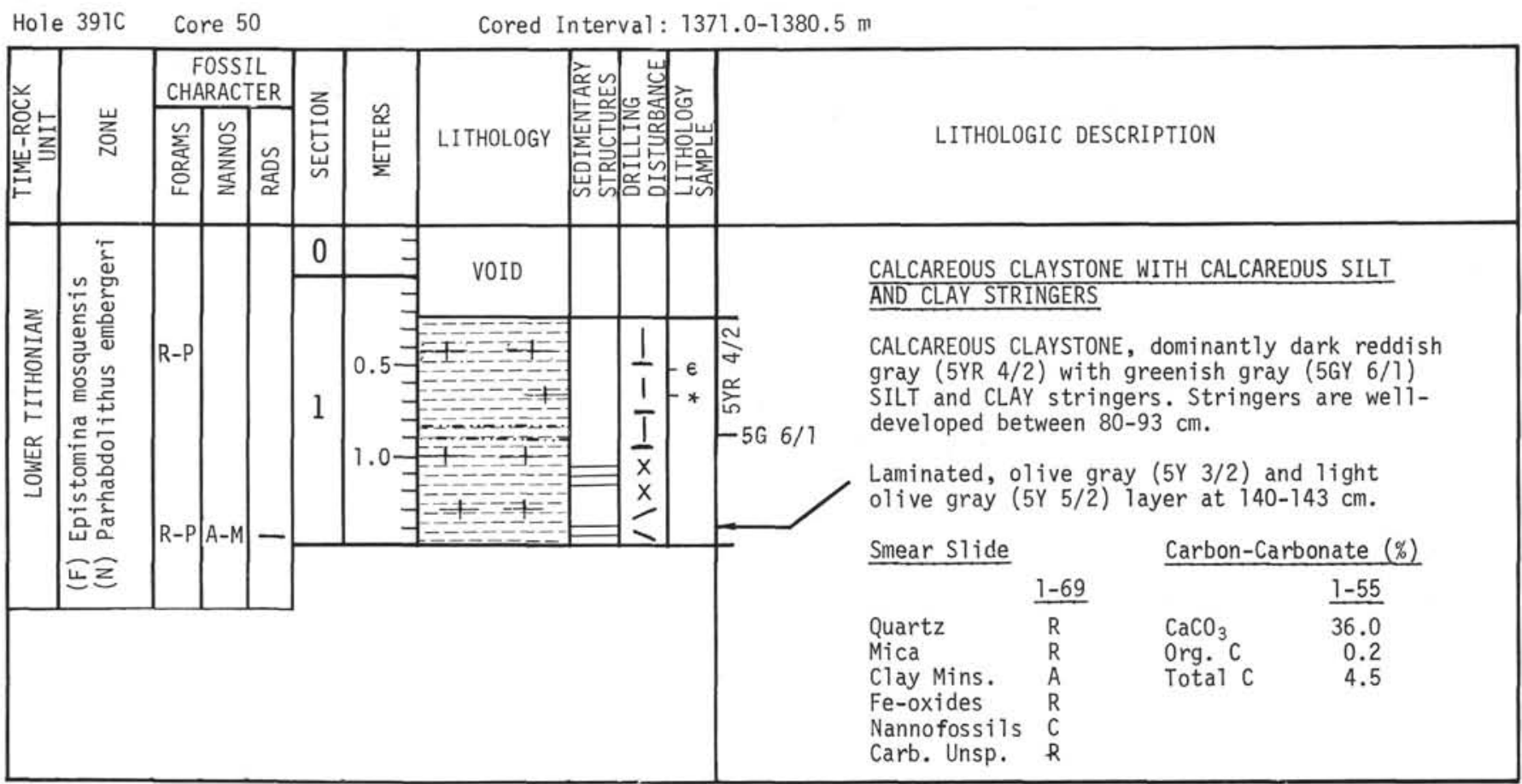




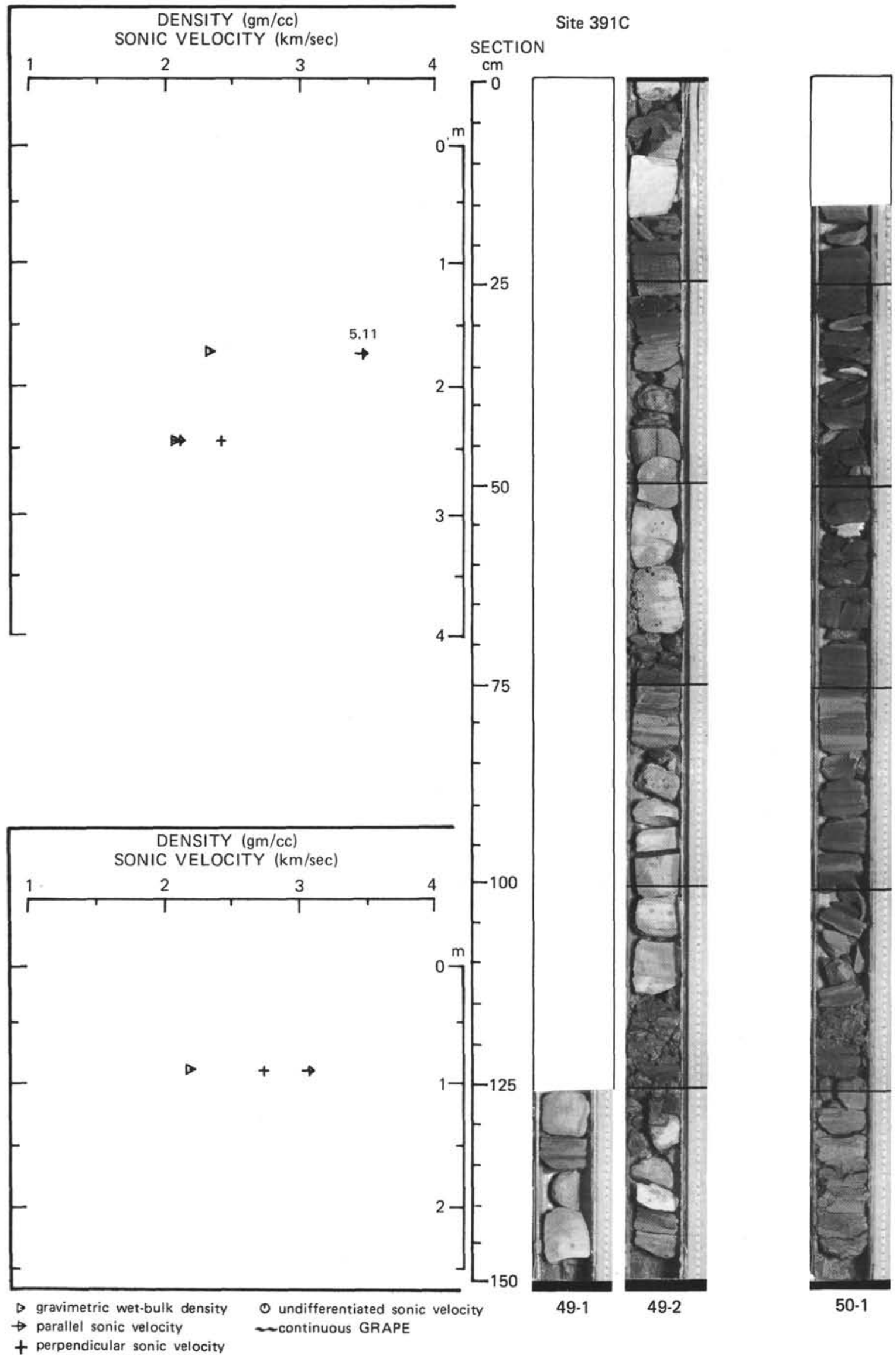




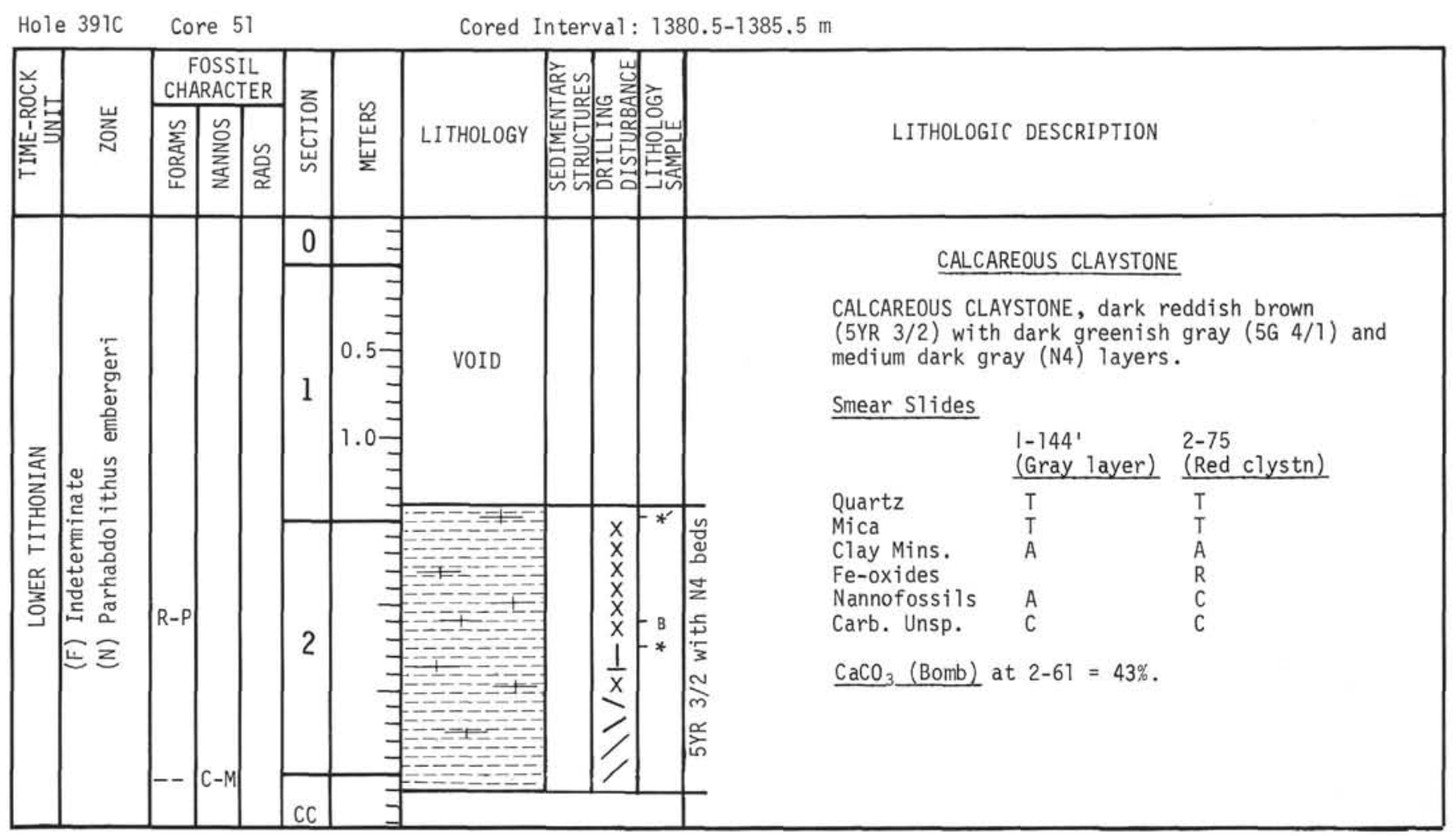




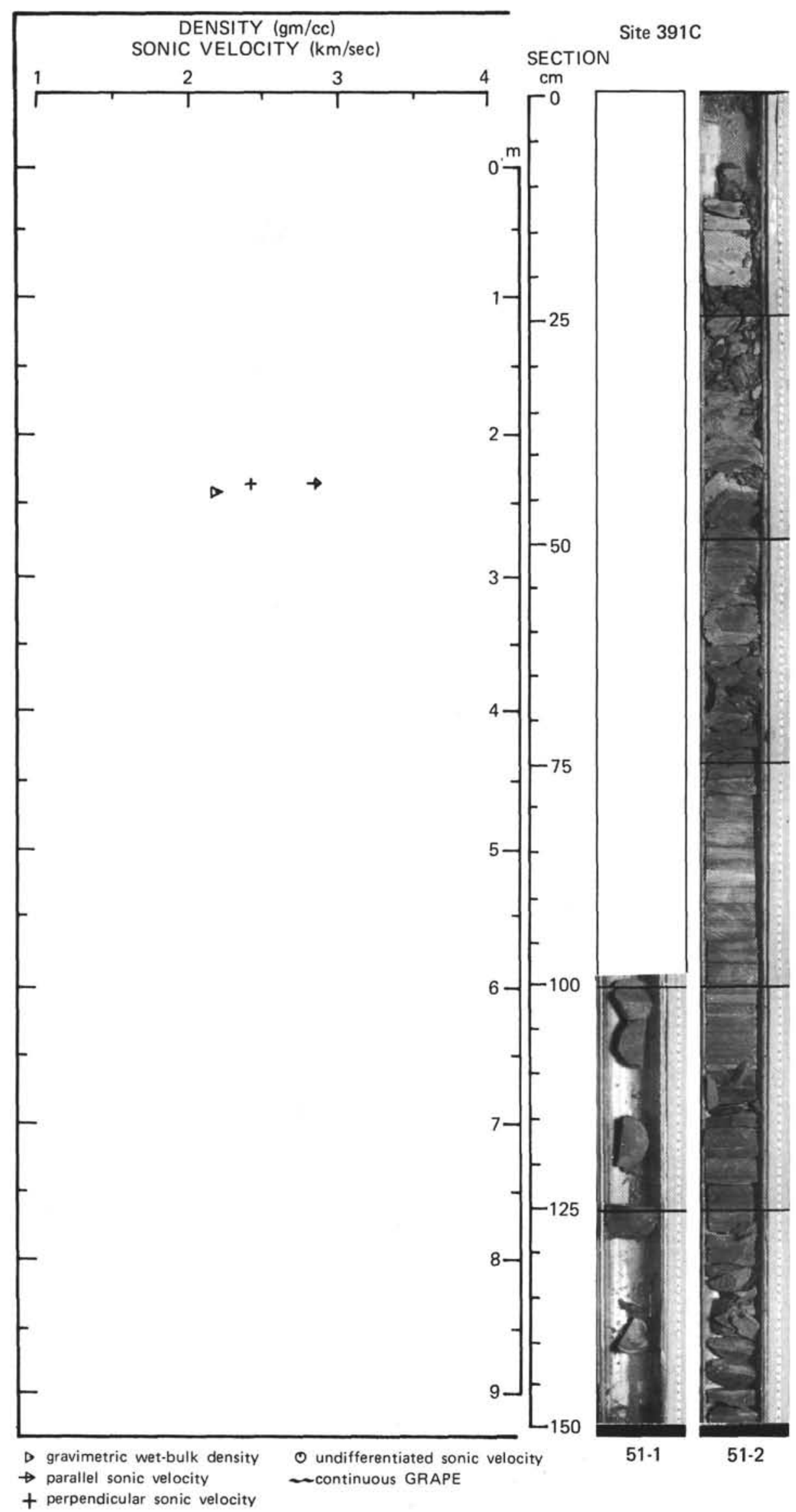


Hole 3910 Core 52

Cored Interval: 1390.0-1399.5 m

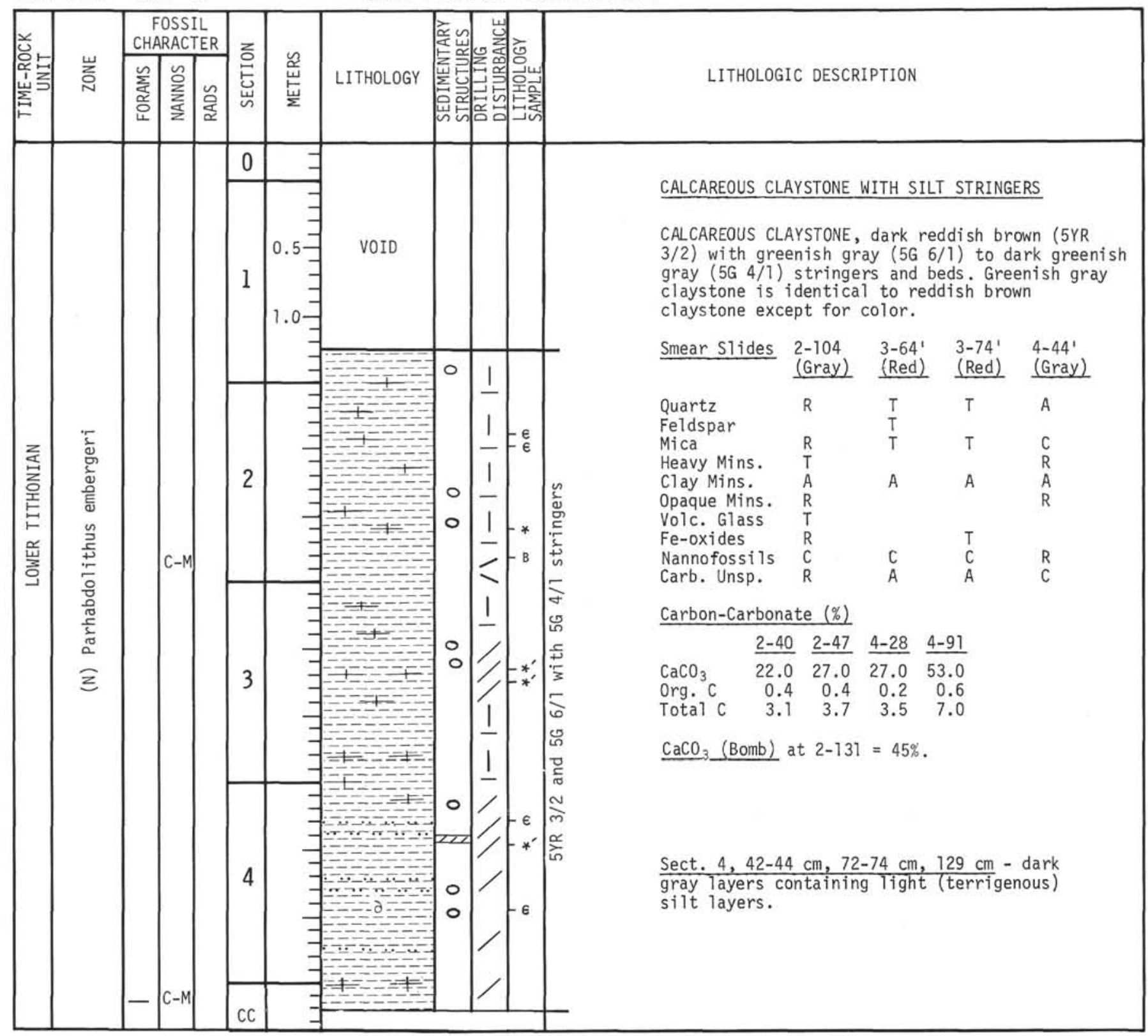


SITE 391

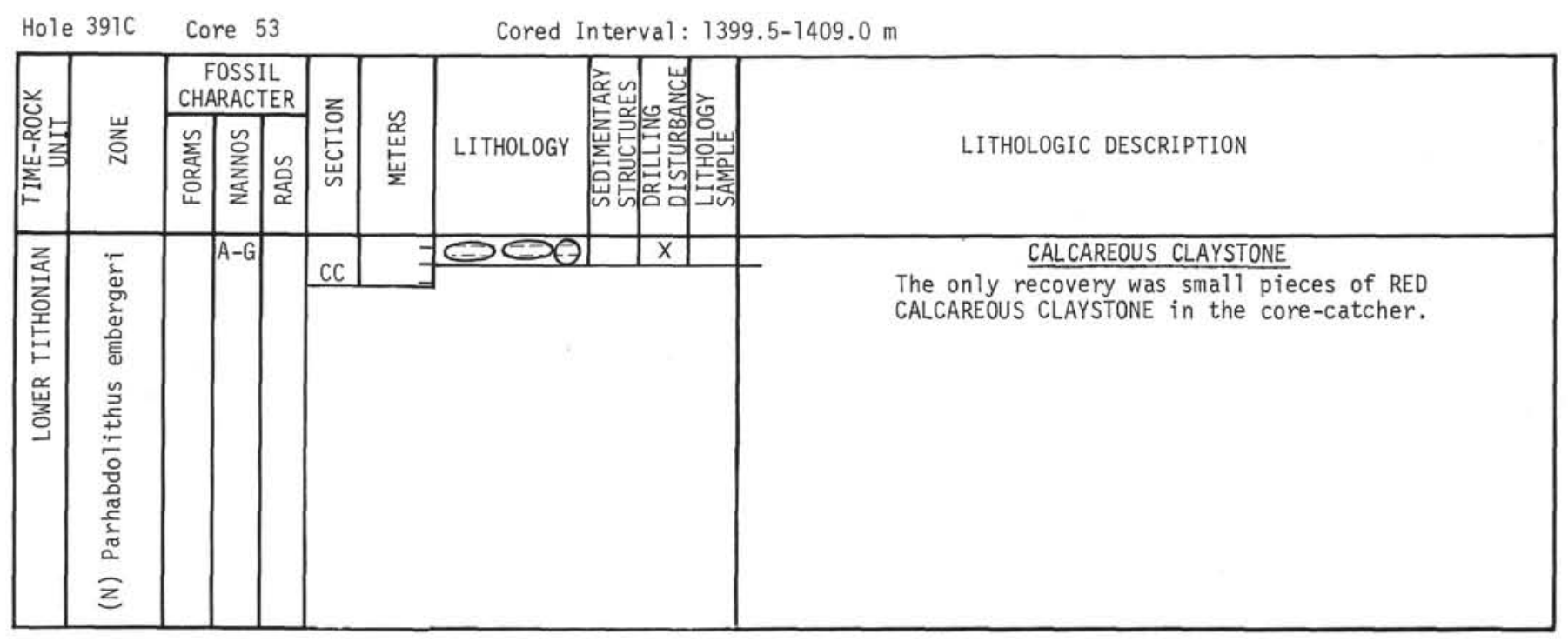

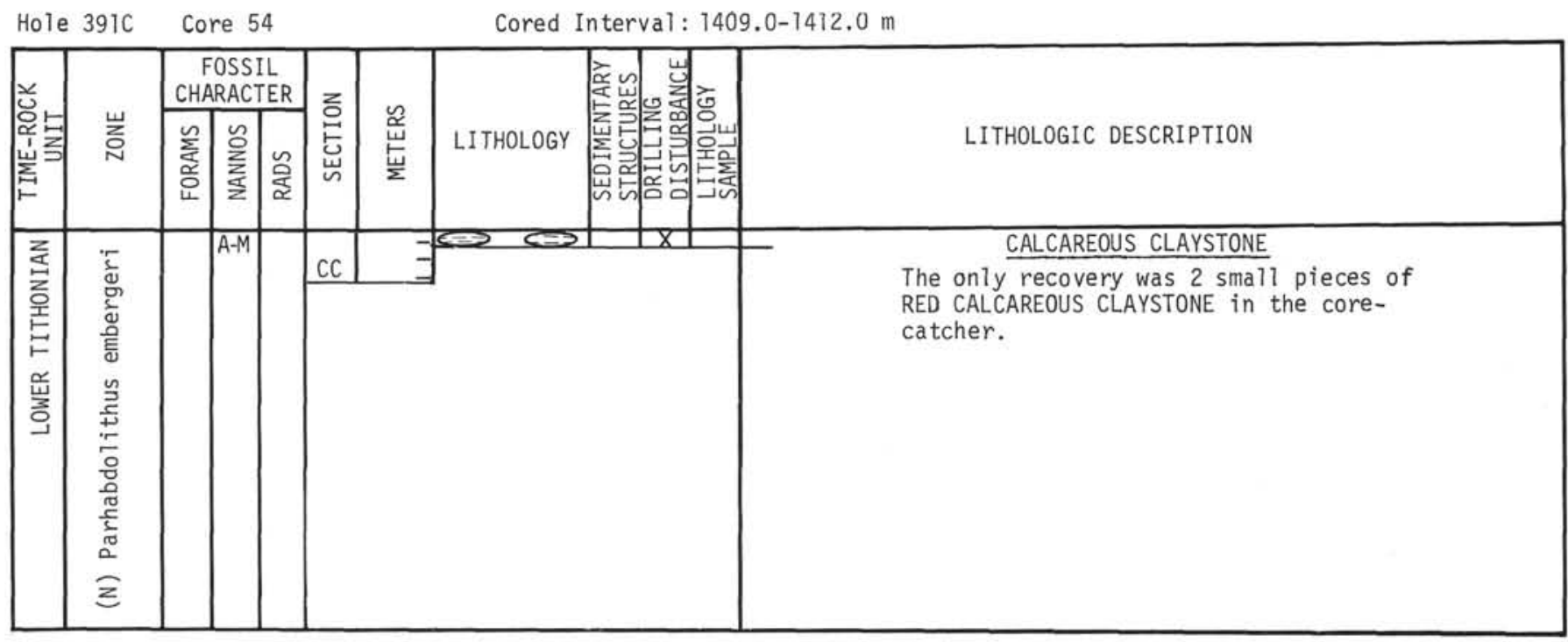

